EDUARDO ROCKENBACH PIRES

\title{
TUTELA INIBITÓRIA COMO INSTRUMENTO DE PREVENÇÃO CONTRA O ASSÉDIO MORAL: A EFETIVIDADE DA JURISDIÇÃO TRABALHISTA NA PROTEÇÃO A DIREITOS DE NATUREZA EXTRAPATRIMONIAL
}

Dissertação de Mestrado

Orientador: Professor Associado Paulo Eduardo Vieira de Oliveira

Universidade de São Paulo

Faculdade de Direito

São Paulo

2014 
EDUARDO ROCKENBACH PIRES

\section{TUTELA INIBITÓRIA COMO INSTRUMENTO DE PREVENÇÃO CONTRA O ASSÉDIO MORAL: A EFETIVIDADE DA JURISDIÇÃO TRABALHISTA NA PROTEÇÃO A DIREITOS DE NATUREZA EXTRAPATRIMONIAL}

Dissertação de mestrado apresentada ao Departamento de Direito do Trabalho e da Seguridade Social da Faculdade de Direito da Universidade de São Paulo, como requisito parcial para obtenção do título de Mestre em Direito, sob orientação do Professor Associado Paulo Eduardo Vieira de Oliveira.

Universidade de São Paulo

Faculdade de Direito

São Paulo 


\section{AGRADECIMENTOS}

Mesmo consciente de que seria impossível consignar aqui agradecimentos específicos a todas as pessoas que os merecem, não posso deixar de assumir o risco de omissões pontuais ao externar, expressamente, minha gratidão àqueles que foram imprescindíveis para a conclusão deste trabalho.

Ao meu pai Edmundo, que me ensinou a viver a leitura, e à minha mãe Vera, que me ensinou a acreditar em sonhos. Pai, Mãe, desde

o começo eu sou o que sou porque leio, sonho e acredito. Muito obrigado, pela vida toda.

Aos meus irmãos Cíntia e André, que sempre me compreenderam e me apoiaram, e a todos os meus familiares. Estamos juntos, sempre; a distância não nos distancia.

Aos meus amigos de ontem, hoje e sempre; aos daqui, aos dali e aos de lá. Em especial, aos parceiros e incentivadores Gustavo

Trierweiler, Marcele Soares e Angela Ribas.

Ao meu orientador, professor Paulo Eduardo, que acreditou no meu projeto e no meu trabalho, e também a todos os professores da

Faculdade de Direito da USP, pelos preciosos ensinamentos; em especial, aos professores Homero Mateus da Silva, Guilherme Feliciano, Jorge Souto Maior e Otávio Pinto e Silva.

À Lia, companheira inseparável, nos mares tranquilos e nos revoltos, e que às vezes acredita em mim mais do que eu mesmo.

Obrigado pela compreensão nos momentos de ausência.

À Sofia, a mais bela semente que já vi germinar, que acredita em mim com tal brilho nos olhos que me desperta a vontade de ser uma pessoa melhor, e de ajudar a construir um mundo melhor. 


\section{RESUMO}

O trabalho tem o objetivo de estudar a tutela inibitória no processo do trabalho, especialmente no sentido da prevenção do assédio moral no ambiente de trabalho. A abordagem parte da perspectiva da proteção dos direitos fundamentais dos trabalhadores, principalmente em face do poder diretivo do empregador. Analisa a vinculação dos particulares às normas de direitos fundamentais e ressalta a importância da vinculação direta ou imediata do empregador às normas de direitos fundamentais, no âmbito da relação de emprego. Põe em relevo a função do processo do trabalho na perspectiva da tutela dos direitos fundamentais. Analisa as características do assédio moral praticado no ambiente de trabalho, sua classificação e suas consequências. Trata das modificações sociais que impuseram novas necessidades ao direito processual, especialmente ao direito processual do trabalho. Aborda a natureza e as características da tutela inibitória, como tutela judicial preventiva da conduta ilícita. Trata dos meios concretos de operar a tutela inibitória no processo do trabalho, com o objetivo de prevenir o assédio moral. Cuida de aspectos controversos da legitimidade para a ação inibitória, bem como de peculiaridades da causa de pedir e da prova. Analisa os requisitos da sentença e da coisa julgada na ação inibitória. Conclama à assunção da lógica da prevenção no direito processual. Realça a necessidade de uma atuação mais criativa e livre dos juízes trabalhistas.

\section{Palavras-chave:}

Tutela inibitória. Processo trabalhista. Direitos fundamentais. Assédio moral. Prevenção. 


\begin{abstract}
The work aims to study the inhibitory injunction in the labor process, especially towards the prevention of bullying in the workplace. The approach starts from the perspective of protecting the fundamental rights of workers, particularly against the directive power of the employer. Analyzes linking the particular standards of fundamental rights and emphasizes the importance of direct or immediate employer to binding rules relating to fundamental rights within the employment relationship. It highlights the role of the procedural labor law from the perspective of the protection of fundamental rights. It analyzes the characteristics of bullying practiced in the workplace, their classification and environmental consequences. It analyzes the social changes that have imposed new requirements of procedural law, especially procedural labor law. It approaches the nature and characteristics of inhibitory injunction, like a judicial protection as a preventive of unlawful conduct. It analyzes the specific means to operate the inhibitory injunction in the labor process, with the goal of preventing bullying. It takes care of controversial aspects of legitimacy to the inhibitory action, as well as peculiarities of the cause of action and proofs. It analyzes the requirements of the sentence and the inhibitory action on res judicata. It urges the assumption of prevention logic in procedural law. It stresses the need for a more creative and free activity of labor judges.
\end{abstract}

\title{
Keywords:
}

Inhibitory injunction. Procedural labor law. Fundamental rights. Bullying. Prevention. 


\section{SUMÁRIO}

1. CONSIDERAÇÕES INICIAIS. ......................................................... 8

2. DELIMITAÇÃO E JUSTIFICATIVA DO TEMA.

3. DIREITOS FUNDAMENTAIS E PROCESSO DO TRABALHO.

3.1. Panorama geral sobre a teoria dos direitos fundamentais.

3.1.1. Conceito.

3.1.2. Noção histórica e gerações de direitos fundamentais.

3.2. Vinculação dos particulares aos direitos fundamentais.

3.2.1. Contextualização do problema.

3.2.2. Fundamentos da vinculação dos particulares aos direitos fundamentais. .....

3.2.3. Modos de vinculação dos particulares aos direitos fundamentais.

3.2.4. Direito do trabalho e vinculação dos particulares aos direitos fundamentais.

3.3. Processo do trabalho como instrumento de proteção de direitos fundamentais.

3.3.1. Leitura constitucional do processo do trabalho no Brasil.

3.3.2. A visão patrimonialista e a necessidade de mudança.

4. ASSÉDIO MORAL NA RELAÇÃO DE EMPREGO.

4.1. Considerações iniciais.

4.2. Noção e espécies de assédio moral.

4.2.1. Dificuldades na formulação de uma definição de assédio moral.

4.2.2. Definições doutrinárias e legislativas. Conceito proposto.

4.2.3. Espécies de assédio moral.

4.2.3.1. Assédio organizacional.

4.2.3.2. Assédio moral vertical descendente. 78

4.2.3.3. Assédio moral horizontal. 
4.2.3.4. Assédio moral vertical ascendente. .......................................................... 84

4.3. Meio ambiente do trabalho e assédio moral. ................................................... 85

4.4. Assédio moral e dignidade da pessoa. .......................................................... $\quad 92$

4.5. Consequências do assédio moral. ............................................................. 98

4.6. Assédio moral e dano moral. ............................................................................. 105

5. A TUTELA INIBITÓRIA E A PREVENÇÃO DO ASSÉdIO MORAL. ... 110

5.1. Considerações iniciais. ............................................................................ 110

5.2. Uma premissa necessária: ato ilícito e dano. ............................................. 117

5.3. Conceito e características da tutela inibitória. ................................................. 120

5.4. Justificação da tutela inibitória. Importância da prevenção do assédio moral.. 123

5.5. Operacionalização da tutela inibitória. Meios executivos. ................................ 128

5.6. Legitimação processual. .............................................................................. 141

5.7. Peculiaridades da causa de pedir e da prova na ação inibitória. ..................... 145

5.8. Sentença e coisa julgada em ação inibitória. ................................................... 151

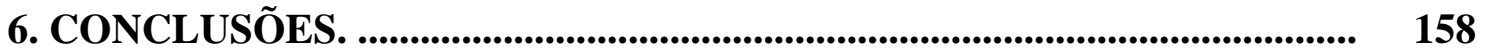

REFERÊNCIAS BIBLIOGRÁFICAS. ................................................................ 162 


\section{CONSIDERAÇÕES INICIAIS}

Você se sente numa guerra?

O seu dinheiro paga o seu pão?

Suas crianças estão na escola?

Você é capaz de se entregar ao amor?

Eu posso estar errado,

Mas preciso cantar esta canção

E questionar... ${ }^{1}$

O tema desta pesquisa - a aplicação da tutela inibitória na prevenção do assédio moral - é ao mesmo tempo instigante e preocupante. Instigante porque se insere em um campo ainda pouco explorado no direito processual do trabalho, que é a tutela jurisdicional preventiva; preocupante porque expõe as agruras de um processo que está a tomar consciência da própria ineficiência ${ }^{2}$.

Trata-se de um trabalho que versa em essência sobre direito processual, o que não significa ignorar as discussões centradas em direito material. Pelo contrário. Uma das premissas da importância da tutela preventiva é, justamente, a necessidade de interdisciplinaridade, e com isso o processo precisa deixar de ser visto de forma isolada da realidade substancial ${ }^{3}$. O processo volta-se à realidade, visa à realidade, e é influenciado por ela; nada mais natural ao estudo do processo, portanto, do que o olhar penetrado pelo prisma do direito material ${ }^{4}$.

\footnotetext{
${ }^{1}$ Ira!. “Um dia como hoje”. In: Meninos da Rua Paulo. São Paulo: WEA, 1991.

2 "Diante da ineficiência do processo - fenômeno incontestável -, cabe aos processualistas buscar alternativas. Nessa linha, propõe-se a releitura da técnica processual, para colocá-la realmente a serviço dos escopos do processo, não permitindo que a forma sobreponha-se ao fim.” (BEDAQUE, José Roberto dos Santos. Efetividade do processo e técnica processual. 2 ed. São Paulo: Malheiros, 2007, p. 90).

3 “O processualista, sem deixar de sê-lo, há de estar atento à indispensável visão orgânica da interação entre o social, o político e o jurídico. Há de estar informado dos conceitos e sugestões que outras ciências lhe possam fornecer e conhecer a vivência do processo como instrumento, conhecer sua potencialidade a conduzir a resultados, ter sensibilidade para as suas deficiências, disposição para concorrer para seu aperfeiçoamento." (DINAMARCO, Cândido Rangel. A instrumentalidade do processo. 15 ed. São Paulo: Malheiros, 2013, p. 184).

4 "De fato, se o processo realiza o direito, não pode o intérprete olhar um sem ver o outro, aplicar um sem considerar o outro, sentir um sem tocar-se pelo outro." (VIANA, Márcio Túlio. Direito de resistência. São Paulo: LTr, 1996, p. 412).
} 
O estudo é movido pela preocupação decorrente da observação da realidade do processo do trabalho. No Brasil de hoje, segunda década do século XXI, é inegável que muitos danos são causados aos trabalhadores (não apenas em virtude de assédio moral) e ficam sem reparação. A ausência de reparação deve-se, por sua vez, a diversos fatores: parcas condições de acesso à justiça, dificuldade de produção de provas na ação judicial, arbitramento de indenizações em valores módicos e, principalmente, impossibilidade de verdadeira reparação do bem jurídico lesado (que pode ser a saúde ou a própria vida da pessoa). Seja como for, parece inviável confrontar com seriedade a afirmação de que o sistema da tutela ressarcitória tem se mostrado insuficiente, também, no âmbito trabalhista.

Que fazer?

Houvesse resposta pronta a essa questão, certamente a realidade do processo seria outra. Porém, na ausência de fórmula acabada, é preciso procurar alternativas para solucionar, ou atenuar, a crise de efetividade do processo. É preciso direcionar os estudos no sentido da busca de instrumentos de proteção à vida, à saúde e aos direitos fundamentais dos trabalhadores ${ }^{5}$. Nesse desiderato é necessário enfrentar dogmas do processo clássico que insistem em oferecer obstáculos a essas tentativas, e eventualmente poderá parecer que a luta é inútil. Mas não se deve esmorecer; muito menos desistir. Devese persistir. Persistir na luta pelo avanço do processo.

Nesse contexto, o sentido do avanço do direito processual é o sentido da tutela processual eficaz dos direitos fundamentais. É esse o horizonte que anima a presente pesquisa; é mirando nesse horizonte que se busca a construção de instrumentos e ferramentas de direito positivo para a proteção dos direitos dos trabalhadores.

Evidentemente, tem-se aqui um trabalho em permanente construção. Por isso, não se há de pretender a formulação de juízos definitivos ou absolutos. A pesquisa é um

\footnotetext{
5 "Em Direito é, efetivamente, assim. Ser realista é ser visionário. Não se constrói uma realidade melhor sem depositar esperanças na consolidação de novos paradigmas jurídicos. Mas só a esperança não basta: é preciso agir. Agir com prudência, é certo; erigir toda construção dogmática sobre os poderosos alicerces da Ciência, porque a jurisprudência 'intuitiva' ou de ímpeto é a primeira a ruir na dança das ideologias. Mas há que agir." (FELICIANO, Guilherme Guimarães. Tutela processual dos direitos humanos nas relações de trabalho. Jus Navigandi. Teresina. Ano 10, n. 910, 30.12 .2005 [Disponível em http://jus2.uol.com.br/doutrina/texto.asp?id=7810. Acesso em 17.10.2010], p. 30)
} 
caminhar e, não obstante a dissertação lhe materialize os resultados, o caminho em si não termina nunca. A caminhada não tem fim.

Deixa-se claro, portanto, que este trabalho representa o estágio conclusivo de uma pesquisa inserida no espaço e no tempo, e não o fechar de portas à reflexão, às críticas e às novas ideias.

Feitas essas observações, cabe ainda nesta introdução uma breve exposição das abordagens que se farão nos próximos capítulos.

O capítulo 2 destina-se a aprimorar a delimitação e a justificativa do tema, na perspectiva acadêmica de sustentar a escolha do objeto da pesquisa.

O capítulo 3 tem por finalidade o estudo dos direitos fundamentais e da relação que têm esses direitos com o processo do trabalho. Parte-se de uma visão panorâmica da propedêutica teórica e histórica dos direitos fundamentais para o estudo da vinculação dos particulares às normas de direitos fundamentais, a inserção desse estudo no direito do trabalho e, finalmente, o papel do direito processual do trabalho nessa mesma problemática. Ainda nesse capítulo se inclui uma abordagem crítica da característica marcadamente patrimonialista do processo do trabalho contemporâneo.

O capítulo 4 é destinado ao estudo do assédio moral na relação de emprego. Ainda aqui se mantém a abordagem substancial do fenômeno, na análise do conceito, das espécies e das implicações do assédio moral no meio ambiente do trabalho, na perspectiva da dignidade da pessoa. Destaca-se a atenção dada à perspectiva organizacional do assédio moral, que traz implicações relevantes para a compreensão do fenômeno do assédio moral nas empresas.

A abordagem processual, propriamente dita, tem sede no capítulo 5. Aí se contém a análise da tutela jurisdicional preventiva que se convencionou chamar de tutela inibitória: seu conceito, suas características e sua justificação na ordem constitucional brasileira. Abordam-se ainda questões pertinentes à operacionalização da tutela inibitória no processo do trabalho, além de aspectos relevantes da legitimação processual, da causa de pedir, da prova, da sentença e da coisa julgada na ação inibitória trabalhista. 
Por fim, não se pode abrir mão de um capítulo de encerramento, com a exposição dos juízos que se possam qualificar como conclusões do trabalho empreendido. Tal é o escopo do sexto e derradeiro capítulo. 


\section{DELIMITAÇÃO E JUSTIFICATIVA DO TEMA}

A pesquisa tem por objeto o estudo da possibilidade e do regime jurídico da aplicação da tutela inibitória em casos de assédio moral no trabalho. A opção do tema decorre da observação da prática forense trabalhista, em que as ações que versam sobre atos de assédio moral são apresentadas, invariavelmente, após a consumação dos danos à vítima.

O sistema é anacrônico. Vive-se uma época na qual a efetiva proteção aos direitos exige do ordenamento jurídico e dos aplicadores da lei medidas de caráter preventivo, e não apenas a clássica tutela de ressarcimento por valor equivalente (indenização de perdas e danos). Isso porque cada vez mais se solidifica a compreensão de que vários bens juridicamente protegidos não admitem a reparação de sua essência por valor monetário equivalente. Não são mensuráveis em dinheiro.

Assim o direito à saúde, à integridade física e psíquica, à honra, entre outros ${ }^{6}$. Não há como quantificar esses direitos em pecúnia. Não haverá, portanto, compensação financeira que satisfaça a vítima e não deixe em débito o ordenamento jurídico, o qual garante o direito de ação e a tutela adequada aos bens protegidos e direitos declarados ${ }^{7}$.

Cumpre ao direito e aos intérpretes, então, envidar esforços no sentido da prevenção das lesões a esses "novos direitos" 89 . Pois bem.

\footnotetext{
6 "Novos direitos ou mesmo o aperfeiçoamento de alguns outros, ou ainda o acréscimo de subsistemas de novas gerações a grandes ramos já existentes, como a não-discriminação, o respeito à privacidade, à dignidade das pessoas, implicam a existência, ainda que potencial, de novos conflitos." (BELTRAN, Ari Possidonio. Direito do trabalho e direitos fundamentais, São Paulo: LTr, 2002, p. 229)

${ }^{7}$ MARINONI, Luiz Guilherme. Técnica processual e tutela dos direitos. 2 ed. São Paulo: RT, 2008, p. 113.

${ }^{8}$ A expressão "novos direitos" foi usada já por Mauro CAPPELLETTI e Bryant GARTH, no célebre Acesso à justiça (Trad. Ellen Gracie Northfleet. Porto Alegre: Sergio Antonio Fabris Editor, 1988).

9 “Não há dúvida de que o ressarcimento em pecúnia, como forma de proteção jurisdicional dos direitos, não está de acordo com os valores do Estado constitucional. O dever estatal de proteger os direitos, especialmente os direitos fundamentais, obviamente demonstra a preocupação com a proteção da integridade dos direitos. Com a proteção da integridade do meio ambiente, do direito do consumidor, do direito à saúde, do direito à educação etc. Na verdade, tais direitos têm uma natureza que não admite a sua transformação em dinheiro. Bem por isso exigem a proteção jurisdicional na forma específica e não a tutela ressarcitória pelo
} 
O tema do assédio moral na relação de emprego é bastante delicado. Em jogo encontra-se a dignidade da pessoa trabalhadora, atacada por condutas hostis do empregador, de superiores hierárquicos ou mesmo de colegas. As consequências do assédio moral, descritas em doutrina, têm efeitos devastadores na vida da vítima e, não raro, de seus familiares.

Daí a justificativa de se empreender o estudo de formas de atuação judicial preventivas do assédio moral. O objetivo é que as lides pertinentes ao assédio moral sejam levadas ao Poder Judiciário antes que as consequências danosas à vida, à saúde e à dignidade da pessoa se concretizem. Que o juiz possa emitir comando de cessar a conduta considerada violenta ou abusiva. Que não reste apenas, e tardiamente, a possibilidade de compensação financeira à vítima.

Ademais, não se pode deixar de constatar que a prevenção dos danos à saúde dos trabalhadores é pensamento que ganha atualmente foros de universalidade ${ }^{10}$. A Constituição Federal previra, já em 1988, no inciso XXII do art. $7^{\circ}$, o direito à "redução dos riscos inerentes ao trabalho, por meio de normas de saúde, higiene e segurança", o que denota a preocupação do constituinte com a prevenção dos danos que possam ser causados ao trabalhador.

Está, enfim, assentada a ideia de que é na prevenção de acidentes do trabalho, doenças ocupacionais e de um modo geral dos danos à saúde do trabalhador que devem se concentrar os esforços dos operadores do direito do trabalho e do direito processual do trabalho ${ }^{11}$. Entretanto, é preciso superar a retórica; é preciso construir caminhos para que a

equivalente." (MARINONI, Luiz Guilherme. Curso de processo civil: teoria geral do processo. v. 1. São Paulo: Editora RT, 2006, p. 229).

${ }^{10}$ É afirmada a ideia de que "não cabe a alienação da saúde, sua permuta com adicionais monetários, mas investimentos criados com políticas sociais e, mormente, empresariais na alteração de condições e métodos do trabalho humano. Para tal fim, vale-se de uma estratégia fundamental, a prevenção" (DINIZ, Ana Paola Santos Machado. Saúde no trabalho: prevenção, dano e reparação. São Paulo: LTr, 2003, p. 50).

${ }^{11}$ Com efeito, "entende-se urgente a criação de mecanismos de proteção à saúde integral do trabalhador (física e psicológica) dentro de um ambiente de trabalho sadio em busca da manutenção para as próximas gerações do valor social do trabalho como fundante de uma democracia igualitária, justa e inclusiva." (OLIVEIRA, Paulo Eduardo Vieira de. Assédio moral no trabalho: caracterização e consequências. São Paulo: LTr, 2013, p. 55) 
prevenção não acabe se tornando lugar-comum de discursos e declarações, com pouca ou nenhuma presença no mundo real do trabalho.

Por certo, há empecilhos que têm de ser enfrentados na busca da tutela preventiva. Um deles - talvez um dos principais - é a reduzida expressão econômica da ação inibitória, o que, na prática atual do processo do trabalho, reduz ou dificulta a incidência dos honorários dos advogados dos empregados. Não obstante esse problema seja de fato circunstancial, é notório que a maior parte das ações trabalhistas é movida por advogados particulares (não os fornecidos pelos sindicatos profissionais) cujos honorários são negociados ad exitum, isto é, em um percentual do proveito financeiro a ser obtido pelo autor no processo. Evidentemente, se o conteúdo do processo é uma obrigação de fazer ou de não fazer (tutela exclusivamente preventiva), não haverá base de cálculo para incidência de honorários advocatícios. Trata-se de um problema de acesso à justiça ${ }^{12}{ }^{13}$.

Outro questionamento que não pode ser ignorado vem da crítica à invariavelmente temida concentração de poderes nas mãos dos juízes. Como se verá oportunamente, o manejo eficaz da tutela inibitória requer a superação de algumas características do processo formatado em parâmetros liberais. Mostra-se necessária a mitigação do princípio da adstrição do juiz ao pedido (especialmente quanto aos meios executivos) e também a invasão da esfera jurídica do réu antes da produção de qualquer dano. Tais concepções seriam inimagináveis no contexto do processo civil de cunho marcadamente liberal.

O trabalho propõe, todavia, uma visão menos liberal do processo; a proposta é tratar o processo - em particular, o processo do trabalho - como o instrumento de

\footnotetext{
12 “A expressão 'acesso à justiça' é reconhecidamente de difícil definição, mas serve para determinar duas finalidades básicas do sistema jurídico - o sistema pelo qual as pessoas podem reivindicar seus direitos e/ou resolver seus litígios sob os auspícios do Estado. Primeiro, o sistema deve ser igualmente acessível a todos; segundo, ele deve produzir resultados que sejam individual e socialmente justos." (CAPPELLETTI e GARTH, 1988, p. 8). Mas “[o] acesso à justiça pode, portanto, ser encarado como o requisito fundamental o mais básico dos direitos humanos - de um sistema jurídico moderno e igualitário que pretenda garantir, e não apenas proclamar os direitos de todos." (ibidem, p. 12). Nesse sentido, para Arion Sayão ROMITA, "de nada vale assegurar direitos sem que sejam instituídos organismos aptos a torná-los efetivos" (Direitos Fundamentais nas Relações de Trabalho. 4 ed. São Paulo: LTr, 2012, p. 177).

${ }^{13}$ Nesse mesmo contexto, o entendimento do Tribunal Superior do Trabalho de que, em regra, não cabem na Justiça do Trabalho honorários advocatícios de sucumbência (súmulas 219 e 329) contribui para dificultar sobremaneira o exercício do direito de ação no tocante a pretensões de caráter preventivo.
} 
salvaguarda e realização de direitos, máxime os direitos fundamentais dos trabalhadores, que têm assento constitucional.

Assim, a ideia é a de que, embora existam riscos e inconvenientes na ampliação do uso da tutela preventiva no processo do trabalho, os problemas mais graves a enfrentar são, em verdade, as violações à dignidade das pessoas nos casos de assédio moral. Essa constatação justifica a procura de um meio idôneo à prevenção dos danos causados pelo assédio moral, embora existam (porque sempre existem!) riscos a correr. É preciso sopesar os riscos.

Uma última ressalva quanto à delimitação do tema: não se propõe a confecção de uma espécie de catálogo de tutelas preventivas de assédio moral. Tal tarefa, além de não ser pertinente aos objetivos de um trabalho científico, seria contraproducente, seja da perspectiva teórica (reduziria a análise à superficialidade das hipóteses conhecidas), seja da perspectiva prática (representaria simplesmente a ampliação do horizonte do direito positivo, sem criticar as amarras do juiz à lei).

O objetivo é, em suma, enfatizar justamente a liberdade (discricionária, não arbitrária) de atuação do juiz no caso concreto, da perspectiva da necessidade de prestação da tutela jurisdicional mais adequada às circunstâncias da realidade examinada pelo juiz, em cada processo. 


\title{
3. PROCESSO DO TRABALHO E DIREITOS FUNDAMENTAIS
}

\author{
Corrida contra o relógio, \\ Silicone contra a gravidade \\ Dedo no gatilho, velocidade \\ Quem mente antes diz a verdade \\ Satisfação garantida \\ Obsolescência programada \\ Eles ganham a corrida antes mesmo da largada [...] \\ Quem são eles? \\ Quem eles pensam que são? ${ }^{14}$
}

\subsection{Panorama geral sobre a teoria dos direitos fundamentais}

\subsubsection{Conceito}

Sem embargo das divergências doutrinárias sobre a terminologia ${ }^{15}$, a expressão direitos fundamentais é usada neste trabalho para designar os direitos assim constantes do rol positivado na Constituição do país. A expressão direitos humanos (ou direitos do homem) teria um caráter mais abrangente, se referiria a direitos consagrados universalmente ou previstos em declarações de alcance internacional ${ }^{16}$, nem sempre coincidentes com os catálogos constitucionais de cada Estado soberano ${ }^{17}$.

\footnotetext{
${ }^{14}$ Engenheiros do Hawaii. “3 3 do plural”. In: Surfando Karmas \& DNA. Rio de Janeiro: Universal, 2002.

${ }^{15}$ Além das expressões mencionadas, são usadas também as seguintes: "liberdades individuais, liberdades públicas, liberdades fundamentais, direitos humanos, direitos constitucionais, direitos públicos subjetivos, direitos da pessoa humana, direitos naturais, direitos subjetivos" ( $c f r$. DIMOULIS, Dimitri; MARTINS, Leonardo. Teoria geral dos direitos fundamentais. 3 ed. São Paulo: Editora RT, 2011, p. 47).

${ }^{16}$ A distinção das noções de direitos humanos e direitos fundamentais é bem trabalhada por Fábio Konder COMPARATO (A afirmação histórica dos direitos humanos. 8 ed. São Paulo: Saraiva, 2013, p. 71). Cf. também, sobre o assunto, ROMITA (2012, p. 57); BRANCO, Ana Paula Tauceda. A colisão de princípios constitucionais no direito do trabalho. São Paulo: LTr, 2007, p. 40; WEIS, Carlos. Os direitos humanos contemporâneos. 2 ed. São Paulo: Malheiros, 2010, pp. 23-24; SILVA, José Antônio Ribeiro de Oliveira. A saúde do trabalhador como um direito humano: conteúdo essencial da dignidade humana. São Paulo: LTr, 2008, pp. 24-25.

${ }^{17}$ Para José Joaquim Gomes CANOTILHO, “direitos do homem são direitos válidos para todos os povos e em todos os tempos (dimensão jusnaturalista-universalista); direitos fundamentais são os direitos do homem, jurídico-institucionalmente garantidos e limitados espacio-temporalmente." (Direito constitucional e teoria da constituição. 7 ed. Coimbra: Almedina, 2003, p. 393).
} 
Nesse panorama, o conteúdo da expressão direitos fundamentais é definido a partir da noção de fundamentalidade formal, isto é, são direitos fundamentais aqueles previstos no catálogo constitucional positivo ${ }^{18}$. É conveniente registrar a construção doutrinária acerca da chamada fundamentalidade material, em função da qual existem direitos fundamentais no ordenamento, independentemente da previsão no rol constitucional, quando observados certos requisitos de equivalência ${ }^{19}$. Todavia, essa discussão não tem maiores consequências para o presente estudo e, por isso, não será desenvolvida a fundo ${ }^{20}$.

Por outro lado, o que é de todo conveniente ressaltar, conforme afirmado e reafirmado por Norberto BOBBIO, é que o problema dos direitos fundamentais não é, nos dias atuais, teórico e de justificação, mas sim prático, político, de concretização ${ }^{21}$.

A Constituição Federal de 1988 possui extenso rol de direitos fundamentais, muitos dos quais ainda estão a exigir concretização. Precisam ser implementados,

${ }^{18}$ Cf. CANOTILHO, 2003, p. 379. ROMITA define direitos fundamentais como "os que, em dado momento histórico, fundados no reconhecimento da dignidade da pessoa humana, asseguram a cada homem as garantias de liberdade, igualdade, solidariedade, cidadania e justiça" (2012, p. 51). Nas palavras de Gilmar Ferreira MENDES, "os direitos fundamentais são elementos integrantes da identidade e da continuidade da Constituição" (Direitos fundamentais e o controle de constitucionalidade. 3 ed. São Paulo: Saraiva, 2004, p. 1 , grifos do original).

${ }^{19}$ Ingo Wolfgang SARLET refere-se, nesse sentido, ao princípio da equivalência, e afirma que "direitos fundamentais em sentido material somente poderão ser os que por sua substância e importância possam ser equiparados aos constantes do catálogo" (A eficácia dos direitos fundamentais. 6 ed. Porto Alegre: Livraria do Advogado Editora, 2006, p. 106). CANOTILHO salienta que "a ideia de fundamentalidade material insinua que o conteúdo dos direitos fundamentais é decisivamente constitutivo das estruturas básicas do Estado e da sociedade. [...] a fundamentalização pode não estar associada à constituição escrita e à ideia de fundamentalidade formal como o demonstra a tradição inglesa das Common-Law Liberties." (2003, p. 379).

${ }^{20}$ É conveniente, todavia, registrar que, como salientado por Flávia PIOVESAN, "sempre se mostrou intensa a polêmica sobre a natureza e o fundamento dos direitos humanos - se são direitos naturais e inatos, direitos positivos, direitos históricos ou, ainda, direitos que derivam de determinado sistema moral. Esse questionamento ainda permanece intenso no pensamento contemporâneo" (Direitos Humanos e o Direito Constitucional Internacional. 11 ed. São Paulo: Saraiva, 2010, p. 113).

${ }^{21}$ Para BOBBIO, "[o] problema fundamental em relação aos direitos do homem, hoje, não é tanto o de justificá-los, mas o de protegê-los. Trata-se de um problema não filosófico, mas político." (A era dos direitos, p. 23, grifo do original). E reforça o autor: "Não se trata de saber quais e quantos são esses direitos, qual é sua natureza e seu fundamento, se são direitos naturais ou históricos, absolutos ou relativos, mas sim qual é o modo mais seguro para garanti-los, para impedir que, apesar das solenes declarações, eles sejam continuamente violados.” (ibidem, p. 25). Cf. também PIOVESAN, 2010, p. 114. 
respeitados, tutelados ${ }^{22}$. Em especial, certamente, entre os chamados direitos sociais, ou direitos fundamentais a prestações.

Permeia, portanto, o presente trabalho esta preocupação: a necessidade de tutelar efetivamente os direitos fundamentais dos trabalhadores, antes da realização definitiva do dano e das consequências nefastas desse dano. Daí a necessidade de construir ferramentas destinadas a atuar antes da violação do direito - área das tutelas inibitórias.

De início, é conveniente uma abordagem da propedêutica dos direitos fundamentais, como sua noção histórica e suas gerações.

\subsubsection{Noção histórica e gerações de direitos fundamentais}

A noção contemporânea de direitos do homem tem raízes no racionalismo iluminista do século XVIII, quando ocorreram as duas principais revoluções que geraram declarações de direitos: a Independência Americana e a Revolução Francesa. O contexto histórico é a luta contra o absolutismo, contra o assim chamado antigo regime.

O surgimento da ideia de direitos fundamentais deu-se, pois, na reação contra os poderes ilimitados do soberano, tal como era configurado o poder político no Estado absolutista $^{23}$. Os direitos previstos nas declarações do século XVIII são, então, basicamente direitos de liberdade, aqueles que geram a abstenção, por parte do Estado, de interferências

\footnotetext{
22 Jorge Luiz SOUTO MAIOR entende que, no âmbito trabalhista, existem "dois obstáculos quase invencíveis para a consagração dos direitos humanos: não reconhecer a agressão, em concreto, dos direitos humanos nas relações intersubjetivas que se desenvolvem em sociedades injustas; e, deixar em segundo plano a efetivação de certos valores humanísticos, que não se compatibilizam, numa equação de custobenefício, com os valores da classe dominante" ("As tutelas inibitórias na proteção dos direitos humanos: uma análise na ótica do direito do trabalho". In: CORREAA, Lelio Bentes. VIDOTTI, Tárcio José [coord.]. Trabalho infantil e direitos humanos: homenagem a Oris de Oliveira. São Paulo: LTr, 2005, p. 211).

23 "Essas ideias encontravam um ponto fundamental em comum, a necessidade de limitação e controle dos abusos de poder do próprio Estado e de suas autoridades constituídas e a consagração dos princípios básicos da igualdade e da legalidade como regentes do Estado moderno e contemporâneo." (MORAES, Alexandre de. Direitos humanos fundamentais. 8 ed. São Paulo: Atlas, 2007, p. 1). No mesmo sentido, cf. PIOVESAN, 2010, p. 143; e LAFER, Celso. A reconstrução dos direitos humanos: um diálogo com o pensamento de Hannah Arendt. São Paulo: Companhia das Letras, 1988, p. 126.
} 
na esfera individual dos $\operatorname{cidadãos}^{24}$. São, por exemplo, os direitos de liberdade de locomoção, de reunião, de manifestação do pensamento, o direito de propriedade, entre outros. Os chamados direitos de primeira geração ${ }^{25}$, ou direitos civis e políticos.

Tais direitos eram carregados de individualismo, que caracteriza a filosofia burguesa dessa época. Pressupunham a igualdade de todos - no aspecto formal ${ }^{26}$-, a qual era também um postulado das declarações mencionadas. O objetivo era possuir liberdade e igualdade entre todos, com o mínimo de intervenção do Estado nas relações privadas. Cabia ao Estado Liberal assegurar a autonomia da vontade das pessoas e proteger a propriedade privada, para que assim a sociedade evoluísse economicamente, segundo as regras do livre mercado.

As declarações não eram, contudo, sensíveis às desigualdades materiais entre os homens, já que dotadas de abstração e generalidade como características marcantes ${ }^{27}$. Com o tempo, essas desigualdades propiciaram novas reivindicações e carecimentos de direitos a ser tutelados ${ }^{28}$. Os movimentos de trabalhadores sob o influxo das revoluções

\footnotetext{
24 "A concepção primitiva dos direitos fundamentais consistia em delimitar as áreas em que a vontade individual poderia livremente se projetar, sem que o Estado aí pudesse interferir." (BELTRAN, 2002, p. 191). "Por isso, a doutrina tradicional sustenta que os direitos de primeira dimensão são direitos de defesa do indivíduo frente ao Estado." (LEITE, Carlos Henrique Bezerra. Eficácia horizontal dos direitos fundamentais na relação de emprego. Revista Brasileira de Direito Constitucional. Número 17, jan/jun 2011, p. 34).

${ }^{25}$ Não raro se usa, em trabalhos doutrinários, em vez do termo utilizado (geração), a expressão dimensão, ou ainda a expressão família. Sem embargo das críticas doutrinárias respectivas (cf. DIMOULIS e MARTINS, 2011, pp. 32-33; SARLET, 2009, p. 56; ROMITA, 2012, p. 102), usa-se o termo geração por ser o mais tradicional e não significar, necessariamente, a superação de uma por outra das gerações históricas dos direitos fundamentais (FELICIANO, 2005, p. 5). Cf. também, sobre as gerações de direitos fundamentais, as considerações de SILVA, J. A., 2008, p. 43-45; e MORAES, Alexandre de. Direito constitucional. 28 ed. São Paulo: Atlas, 2012, p. 29.
}

${ }^{26}$ SILVA, J. A., 2008, p. 45.

27 BOBBIO, referindo-se à Declaração Universal dos Direitos do Homem de 1948, escreveu que ela "conserva apenas um eco porque os homens, de fato, não nascem livres nem iguais. São livres e iguais com relação a um nascimento ou natureza ideais, que era precisamente a que tinham em mente os jusnaturalistas quando falavam em estado de natureza. A liberdade e a igualdade dos homens não são um dado de fato, mas um ideal a perseguir; não são uma existência, mas um valor; não são um ser, mas um dever-ser." (2004, p. 29).

${ }^{28}$ A ideia de novos carecimentos é usada a partir da explanação de BOBBIO acerca do caráter histórico dos direitos do homem. Para ele, "não é preciso muita imaginação para prever que o desenvolvimento da técnica, a transformação das condições econômicas e sociais, a ampliação dos conhecimentos e a intensificação dos meios de comunicação poderão produzir tais mudanças na organização da vida humana e das relações sociais que se criem ocasiões favoráveis para o nascimento de novos carecimentos e, portanto, para novas demandas de liberdade e de poderes." (2004, p. 33). No mesmo sentido a doutrina de FELICIANO (2005, p. 2). 
industriais e da filosofia marxista ${ }^{29}$, já no século XIX, fizeram com que uma segunda geração de direitos do homem surgisse: a dos direitos econômicos e sociais ${ }^{30}$.

Os direitos de segunda geração têm a missão de buscar a igualdade material entre as pessoas e, em boa parte, requerem do Estado uma prestação, um agir, e não a abstenção que satisfaz os direitos de primeira geração ${ }^{31}$.

O contexto histórico do nascimento da segunda geração dos direitos humanos revela, na perspectiva dos direitos dos trabalhadores, a exploração selvagem da mão de obra de homens, mulheres e até mesmo crianças nas fábricas do capitalismo incipiente ${ }^{32}$, mediante o pagamento de salários muito baixos ${ }^{33}$, suficientes apenas para assegurar a mera

${ }^{29}$ SOUTO MAIOR, J. L. O direito do trabalho como instrumento de justiça social. São Paulo: LTr, 2000, pp. 59-60.

30 “Os direitos da segunda geração são os direitos sociais, culturais e econômicos, bem como os direitos coletivos ou de coletividades, introduzidos no constitucionalismo do Estado Social" (BELTRAN, 2002, p. 197-198). Cf. também PIOVESAN, 2010, p. 144.

31 "À medida que as sociedades do laissez-faire cresceram em tamanho e complexidade, o conceito de direitos humanos começou a sofrer uma transformação radical. A partir do momento em que as ações e relacionamentos assumiram, cada vez mais, caráter mais coletivo que individual, as sociedades modernas necessariamente deixaram para trás a visão individualista dos direitos, refletida nas 'declarações de direitos', típicas dos séculos dezoito e dezenove.” (CAPPELLETTI e GARTH, 1988, pp. 10-11). “A chamada segunda geração de dos direitos humanos surge em decorrência da deplorável situação da pobre das cidades industrializadas da Europa Ocidental, constituída sobretudo por trabalhadores expulsos do campo e/ou atraídos por ofertas de trabalho nos grandes centros." (WEIS, 2010, p. 49).

"Verifica-se então que os ordenamentos jurídicos passam a permitir que o indivíduo possa exigir do Estado, além do dever de abstenção nos seus direitos de primeira dimensão, uma atuação positiva, a fim de assegurar diretamente a realização de um direito de segunda dimensão.” (LEITE, 2011, p. 35). Cf. também LAFER, 1988, p. 127.

32 A "sociedade que se formou demonstrava claramente ser necessária a luta por uma outra plataforma emancipatória, já que havia restado inviabilizado o exercício substancial do direito à liberdade [...]. Assim, já na primeira metade do século XIX, diagnosticava-se uma violenta pauperização do proletariado naquela sociedade em que os contratos de emprego firmados entre o rico e o pobre - fosse este quem quer fosse [sic], ou seja, criança, adulto, homem, mulher, mutilado, doente, idoso ou gestante - tinham suas cláusulas absolutamente convalidadas pelo tal Estado Liberal que se limitava a um papel de mero árbitro da sociedade responsável por afirmar a condição de liberdade e de igualdade desses cidadãos operários" (BRANCO, 2007, pp. 42-43). No mesmo sentido, cf. SOUTO MAIOR (2000, p. 59).

Manuel Alonso OLEA refere o "abuso do trabalho infantil" na época, com jornadas de até dezesseis horas por dia, cumpridas por crianças de oito ou nove anos (Introdução ao direito do trabalho. Tradução da 5 ed. espanhola. Curitiba: Genesis, 1997, p. 333).

33 Segundo SOUTO MAIOR, a Revolução Industrial ocorreu primeiramente na Inglaterra, em razão das condições favoráveis proporcionadas, entre outros fatores, pela abundância de mão de obra nas cidades, o que "gerou baixos ganhos para os trabalhadores e altos lucros para os industriais. Assim, vê-se como a ideia de lucro baseada em baixo custo da mão de obra é da própria essência da industrialização” (2000, p. 56). No mesmo sentido, cf. OLEA, 1997, p. 328-329. 
- e precária - sobrevivência dos trabalhadores ${ }^{34} 35$. Às vezes, sequer em sobrevivência se poderia falar: tantos acidentes ocorriam nas fábricas, que muitos trabalhadores morreram ou foram mutilados, em situações amparadas no princípio da igualdade formal, isto é, contratos formalizados regularmente, entre pessoas dotadas de capacidade e autonomia para se vincularem a obrigações ${ }^{36}$.

Foi se revelando à consciência social $^{37}$ a brutal desigualdade entre as partes contratantes nesse tipo de situação: de um lado havia um empresário industrial com capital acumulado e disponível; de outro lado, miseráveis desprovidos de capital e de outro meio de se manterem vivos que não a alienação da sua força de trabalho, com nulas chances de efetivar uma real negociação de valor de salário, dada a enorme disponibilidade de mão de

\footnotetext{
34 "O ritmo acelerado do trabalho, a acumulação de capital, a reserva de mão-de-obra, o individualismo, o empreendedorismo, o espírito liberal, a coexistência de todos esses fatores repercute intensamente nas fábricas, gerando consequências muito desastrosas para os trabalhadores e, paradoxalmente, para o próprio modelo recém-criado." (SOUTO MAIOR, J. L. Curso de direito do trabalho: teoria geral do direito do trabalho, volume I: parte I. São Paulo: LTr, 2011, p. 134).

"A liberdade de mercado, maior aspiração da ascendente burguesia, propiciou o desenvolvimento do regime capitalista de produção, mas, na busca frenética por produtividade e majoração do lucro, deu-se a exploração desumana dos seres humanos trabalhadores, espoliados em seus direitos mais fundamentais, dentre os quais a saúde e a própria vida, em muitos casos; demais, a perda gradativa da saúde levava a falecimentos precoces dos laboristas, o que não era bom nem mesmo para os industriais." (SILVA, J. A., 2008, p. 45).
}

${ }^{35}$ Oliveira VIANA fez uma descrição da época que merece leitura direta: "No seu inframundo repululava a população operária: era toda uma ralé fatigada, sórdida, andrajosa, esgotada pelo trabalho e pela subalimentação; inteiramente afastada das magistraturas do Estado; vivendo em mansardas escuras, carecidas dos recursos mais elementares de higiene individual e coletiva; oprimida pela deficiência dos salários; angustiada pela instabilidade do emprego; atormentada pela insegurança do futuro, próprio e da prole; estropiada pelos acidentes sem reparação; abatida pela miséria sem socorro; torturada na desesperança da invalidez e da velhice sem pão, sem abrigo, sem amparo. Só a caridade privada, o impulso generoso de algumas almas piedosas, sensíveis a essa miséria imensa, ousava atravessar as fronteiras deste inframundo, os círculos tenebrosos deste novo Inferno, para levar, aqui e ali, espaçada e desordenadamente, o lenitivo das esmolas, quero dizer: o socorro aleatório de uma assistência insuficiente. Os capitães de indústria, ocupados com a acumulação e a contagem de seus milhões e o gozo dos benefícios de sua riqueza, não tinham uma consciência muito clara do que significava a existência deste inframundo da miséria, que fica do outro lado da vida, longe de suas vistas aristocráticas, e cujos gritos de ódio, cujas apóstrofes indignadas, cujas reivindicações de justiça eles não estavam em condições de ouvir e, menos ainda, de entender e atender." (Apud SÜSSEKIND, Arnaldo et al. Instituições de direito do trabalho. 22 ed. São Paulo: LTr, 2005, p. 35).

36 “O liberalismo pujante considerava inadmissível qualquer interferência na liberdade do operário de trabalhar quanto desejasse, para quem quer que fosse, nas condições que entendesse para si convenientes. [...] Os problemas oriundos desse pensamento foram imensos, já que as indústrias floresceram tendo como único norte o ganho econômico, espaço não havendo para ponderações acerca da saúde do operário." (DINIZ, 2003, p. 22-23). Cf. também SIMÓN, Sandra Lia. A proteção constitucional da intimidade e da vida privada do empregado. São Paulo: LTr, 2000, p. 22-25.

${ }^{37}$ OLEA, 1997, p. 361. 
obra barata que se apresentava nas cidades de então ${ }^{38}$. Cada trabalhador tinha de se agarrar desesperadamente ao emprego que lhe fosse oferecido, sob pena de morrer de fome.

Assim, a despeito da beleza dos discursos e das regras lógicas do livre mercado, não existia, em tal contexto, verdadeira igualdade. $\mathrm{O}$ dogma da igualdade formal servia apenas para soterrar qualquer esperança de mudar a realidade daquelas pessoas ${ }^{39}$. Era preciso superar a igualdade formal e partir em busca de uma igualdade substancial (ou material), para o quê era exigível a intervenção do Estado nas relações sociais, de modo a proteger os núcleos básicos dos direitos das pessoas em condições precárias. Um mínimo de direitos para a vida digna era dever do Estado.

Daí as fortes reivindicações e o surgimento dos direitos econômicos e sociais, amparados em deveres estatais de prestação ${ }^{40}$.

Retoma-se, aqui, a ideia que vinha de ser abordada, de concretização dos direitos sociais. Como não basta a mera abstenção, pelo contrário, envolve um agir dispendioso (do Estado e eventualmente de particulares, como se verá adiante), a realização dos direitos sociais prestacionais costuma ser postergada, não raro sem argumentação mais consistente do que a menção aos custos envolvidos nas prestações prometidas pelo direito fundamental ${ }^{41}$.

\footnotetext{
38 "É neste sentido, ademais, que o longo processo de concentração de terras, conduzindo os camponeses para as cidades, onde restam empobrecidos, favorece a formação do exército de mão-de-obra que, em razão da necessidade, se submete ao trabalho fabril, sendo elementos essenciais para o desenvolvimento do capitalismo" (SOUTO MAIOR, 2011, p. 136).

${ }^{39}$ Sobre o tema, cf. COMPARATO, 2013, p. 65-66.

${ }^{40}$ Toma corpo, a partir daí, a discussão sobre o chamado "custo dos direitos" - questão essa presente no debate atual dos direitos fundamentais no Brasil. Cf. sobre o assunto, por todos, SARLET, 2009, p. 373.

${ }^{41}$ Aliás, a própria cláusula denominada reserva do possível não é imune a críticas, quando usada para restringir a eficácia de direitos fundamentais: "Não há possibilidade de mitigar os efeitos da norma definidora do direito fundamental social como sugere a não fundamentada - e da discussão alemã mal importada figura da 'reserva do possível'." (DIMOULIS e MARTINS, 2011, p. 98). Segundo esses autores, "o intérprete e o aplicador do direito não devem se preocupar com a figura da reserva do possível, e sim com a determinação rigorosa da área de proteção de cada direito. A pergunta crucial é saber o que exatamente garante a Constituição ao titular de certo direito fundamental prestacional ou social" (ibidem, p. 101, grifo do original), e acrescentam: "Tendo estabelecido a área de proteção do direito de maneira rigorosa, cabe ao Estado realizar a prestação, sendo as alegações de 'impossibilidade' irrelevantes, tal como é irrelevante a alegação do contribuinte de que se encontra na impossibilidade de pagar seus impostos." (ibidem, p. 102). Também sobre a reserva do possível, cf. BRANCO, 2007, p. 46.
} 
Além disso, há outro enfoque que precisa ser dado a essa eterna carência de concreção dos direitos sociais.

A humanidade chegou a um desequilíbrio tal, no início do século $\mathrm{XX}$, que se colocou em risco o próprio modelo de produção capitalista. A concorrência acirrada no plano internacional contribuiu para a eclosão da Primeira Guerra Mundial, que durou de 1914 a $1918^{42}$. Os danos foram imensuráveis, seja no aspecto humano das vidas perdidas, seja no próprio aspecto econômico, em razão da perda de mão de obra masculina e também da destruição de parques industriais. O cenário era de devastação, de verdadeiro colapso ${ }^{43}$, e um lampejo de consciência coletiva ${ }^{44}$ levou à valorização do trabalho humano e das garantias sociais, no Tratado de Versalhes, que regulou, já em 1919, as relações decorrentes do conflito.

O relevante documento declarou expressamente que o trabalho humano não pode ser considerado como mercadoria de comércio $^{45}$, e fixou as bases de um sistema capitalista responsável - que teria como limite de atos de concorrência a observância das garantias sociais dos trabalhadores. Dito de outro modo: não seria justificável a redução de custos e preços se essa redução fosse operada a partir do sucateamento de garantias sociais.

$\mathrm{Na}$ mesma esteira ideológica, veio nessa época o movimento conhecido como constitucionalismo social, capitaneado pelas Constituições do México, de 1917, e da Alemanha (Weimar), de $1919^{46}$. Os direitos econômicos e sociais passaram a ser vistos em

\footnotetext{
${ }^{42}$ SOUTO MAIOR, nesse sentido, sustenta que "enquanto os trabalhadores se organizam internacionalmente, o capital se desorganiza, visto que sua necessidade de expansão que não é mais suprida pelo colonialismo conduziu os Estados europeus a uma concorrência entre si, notabilizando-se os confrontos políticos entre a França e a Alemanha e a concorrência econômica entre a Alemanha e a Inglaterra" (2011, p. 242).

43 "O fato é que esse período de formação do capitalismo conduz a humanidade ao colapso social, político e econômico" (SOUTO MAIOR, 2011, p. 248).

${ }^{44}$ Nas palavras de COMPARATO, "a compreensão da dignidade suprema da pessoa humana e de seus direitos, no curso da História, tem sido, em grande parte, o fruto da dor física e do sofrimento moral. A cada grande surto de violência, os homens recuam, horrorizados, à vista da ignomínia que afinal se abre claramente diante de seus olhos; e o remorso pelas torturas, pelas mutilações em massa, pelos massacres coletivos e pelas explorações aviltantes faz nascer nas consciências, agora purificadas, a exigência de novas regras de uma vida mais digna para todos" (2013, p. 50).

45 No art. 427 do Tratado, lê-se o "princípio dirigente" de que "o trabalho não deve ser considerado simplesmente como mercadoria ou artigo de comércio".

${ }^{46}$ WEIS, 2010, p. 49; SILVA, J. A., 2008, p. 50-51.
} 
capítulos próprios dos textos constitucionais, o que reforçou a relevância desses direitos e a importância de sua efetiva implantação ${ }^{47}$.

O Tratado de Versalhes também criou a Organização Internacional do Trabalho (OIT), constituída por representantes dos governos, dos empresários e dos trabalhadores (composição tripartite), e que viria a editar normas de alcance internacional acerca de direitos e regulamentações gerais no âmbito das relações de trabalho ${ }^{48}$. Na expressão de PIOVESAN, a criação OIT foi um importante precedente no processo de internacionalização dos direitos humanos ${ }^{49}$.

Entretanto, a despeito dos horrores vivenciados pelas populações na guerra, o espírito da concorrência capitalista no contexto internacional não foi alterado em sua essência. Tanto que as principais potências econômicas europeias lançaram mão de "ratificações condicionadas" de algumas Convenções da OIT, de modo que as regulamentações internacionais não entrariam em vigor em seu ordenamento interno antes que os Estados concorrentes também as introduzissem em seus respectivos ordenamentos $^{50}$.

Não houve, então, como se vê, autêntica tomada de consciência da importância do respeito à dignidade humana e às garantias sociais dos trabalhadores. As

\footnotetext{
${ }^{47}$ Segundo LAFER, o constitucionalismo social veio também a influenciar a Constituição brasileira de 1934 (1988, p. 128).

${ }^{48}$ O preâmbulo da Constituição da Organização Internacional do Trabalho é repleto de significado no que diz respeito à importância de resguardar e efetivar os direitos sociais. Reza o preâmbulo que "a paz para ser universal e duradoura deve assentar sobre a justiça social" e também que "existem condições de trabalho que implicam, para grande número de indivíduos, miséria e privações, [e] o descontentamento que daí decorre põe em perigo a paz e a harmonia universais". Finalmente, dispõe que "a não adoção por qualquer nação de um regime de trabalho realmente humano cria obstáculos aos esforços das outras nações desejosas de melhorar a sorte dos trabalhadores nos seus próprios territórios". Daí o escopo de criação da própria OIT, encarregada, segundo o art. $1^{\circ}$ de sua Constituição, de "promover a realização do programa exposto no preâmbulo".
}

${ }^{49}$ 2010, p. 117. A autora reforça ainda que "o advento da Organização Internacional do Trabalho, da Liga das Nações e do Direito Humanitário registra o fim de uma época em que o Direito Internacional era, salvo raras exceções, confinado a regular relações entre Estados, no âmbito estritamente governamental. Por meio desses institutos, não mais se visava proteger arranjos e concessões recíprocas entre Estados; visava-se, sim, o alcance de obrigações internacionais a serem garantidas ou implementadas coletivamente, que, por sua natureza, transcendiam os interesses exclusivos dos Estados contratantes", essas obrigações "voltavam-se à salvaguarda dos direitos do ser humano" (ibidem, p. 118-119).

${ }^{50}$ Quanto a esses dados históricos, cf. SOUTO MAIOR, 2011, p. 263. 
maiores preocupações estavam voltadas, isso sim, à concorrência internacional; isto é, aos custos gerados pelo respeito às garantias sociais que se avolumavam, e que causariam a bancarrota de alguns se todos os concorrentes não as respeitassem de igual modo.

Sobrevieram então os conflitos da Segunda Guerra Mundial, entre 1939 e 1945, e depois a criação da Organização das Nações Unidas (ONU), verdadeiro marco histórico do século $\mathrm{XX}^{51}$, seguida da assinatura da Declaração Universal dos Direitos do Homem, em $1948^{52}$. Esse documento reconhece, no preâmbulo, “a dignidade inerente a todos os membros da família humana", e estabelece direitos fundamentais de todos os seres humanos, alguns relacionados ao objeto específico desta pesquisa, como o direito do artigo VIII, de "receber dos tribunais nacionais competentes remédio efetivo para os atos que violem os direitos fundamentais".

A Declaração Universal veio a ser regulamentada em 1966, por dois pactos autônomos (esses sim, tratados internacionais): o "Pacto Internacional dos Direitos Civis e Políticos" e o "Pacto Internacional dos Direitos Econômicos, Sociais e Culturais". A separação se deveu à tensão ideológica entre os Estados Unidos da América e a União das Repúblicas Socialistas Soviéticas (URSS), isto é, a materialização política da tensão entre capitalismo e socialismo, tensão essa que ficou conhecida historicamente como "guerra fria”. Assim, os países do bloco alinhado à potência capitalista firmaram sem oposições o pacto dos direitos civis e políticos, mas resistiram ao pacto dos direitos sociais; pelo contrário, os países do bloco alinhado à potência socialista firmaram o pacto dos direitos sociais, e resistiram ao pacto dos direitos civis e políticos ${ }^{53}$.

$\mathrm{Na}$ última quadra do século XX a União Soviética ruiu, e a tensão da guerra fria deu lugar à hegemonia do bloco capitalista. Isso ocorreu em tempos já tomados pela ideologia do neoliberalismo, o qual tem como base a desregulamentação e flexibilização

\footnotetext{
51 Segundo PIOVESAN, a criação das Nações Unidas "demarca o surgimento de uma nova ordem internacional” (2010, p. 130). Cf. também, sobre o assunto, SILVA, J. A., 2008, p. 56-57.

52 PIOVESAN avalia que a "Declaração consolida a afirmação de uma ética universal ao consagrar um consenso sobre valores de cunho universal a serem seguidos pelos Estados" (2010, p. 141). A mesma autora noticia de outro lado que a Declaração não é Tratado, e sim Resolução, razão pela qual "não apresenta força de lei" (ibidem, p. 148); contudo, traz as argumentações doutrinárias que fundamentam a visão de partes da Declaração como direito costumeiro internacional (ibidem, p. 150).
}

${ }^{53}$ COMPARATO, 2013, p. 292; WEIS, 2010, p. 55-56; PIOVESAN, 2010, p. 164-191. 
dos direitos dos trabalhadores, em uma perspectiva de desenvolvimento da economia em livre mercado. Não há muitas dificuldades, então, em compreender que era mais do que conveniente, na ótica do capitalismo neoliberal, manter as disposições concernentes aos direitos sociais no âmbito da retórica e das boas intenções. O discurso de efetividade de tutela dos direitos sociais representa, nesse âmbito, uma quebra das intenções neoliberais.

Assim, o desafio que se impõe ainda hoje é, como já se disse, o de concretizar e efetivar a tutela dispensada aos direitos sociais. Desafio esse que envolve diretamente o Poder Judiciário e o próprio processo do trabalho, conforme abordagem que será feita mais à frente ${ }^{54}$.

Pois bem. Além dos direitos fundamentais de primeira e de segunda geração, a doutrina ainda faz referência aos direitos de terceira geração, os quais seriam os direitos ligados à solidariedade ou - para os autores que salientam a relação com o lema da Revolução Francesa ${ }^{55}$ - à fraternidade. São direitos ligados ao desenvolvimento, e superam a dicotomia dos direitos individuais e coletivos: destinam-se ao gênero humano propriamente dito, não a indivíduo singular qualquer.

Paulo BONAVIDES ${ }^{56}$ lista cinco direitos básicos que compõem a terceira geração: (i) direito ao desenvolvimento, (ii) direito à paz, (iii) direito ao meio ambiente, (iv) direito de propriedade sobre o patrimônio comum da humanidade e (v) direito de comunicação.

Dentre esses direitos listados, assume especial relevância, para os fins específicos da presente pesquisa, o direito ao meio ambiente, e por essa razão uma análise

\footnotetext{
${ }^{54}$ Vide tópico 3.3, infra.

55 Nessa visão, o lema "Liberdade, Igualdade e Fraternidade" teria antecipado as gerações de direitos humanos e também a ordem de surgimento dessas gerações. A primeira geração, a dos direitos civis e políticos, seria fundada na "liberdade"; a segunda geração, a direitos econômicos e sociais, seria fundada na "igualdade" (máxime no aspecto material ou substancial); já a terceira geração, a dos direitos ao desenvolvimento, seria fundada na "fraternidade". (BONAVIDES, Paulo. Curso de direito constitucional. 13 ed. São Paulo: Malheiros, 2003, p. 563).
}

${ }^{56}$ BONAVIDES, 2003, p. 569. 
mais detida do tema (em especial versando o meio ambiente do trabalho) será levada a cabo em tópico próprio ${ }^{57}$.

Por fim, cumpre mencionar que no entendimento de alguns autores existiria ainda uma quarta geração de direitos fundamentais ${ }^{58}$, composta de direitos ligados à implementação efetiva do Estado Social, no que BONAVIDES denomina a "globalização política”. Seriam, no ápice do caminhar histórico dos direitos fundamentais, os direitos à democracia, à informação e ao pluralismo ${ }^{59}$.

Feita essa introdução acerca da teoria geral dos direitos fundamentais, passa-se ao estudo dos principais aspectos do problema da vinculação de particulares aos direitos fundamentais, ou da eficácia privada (ou horizontal) dos direitos fundamentais. Trata-se de tema de máxima relevância para o desenvolvimento deste trabalho e de suas proposições, uma vez que todo o raciocínio é construído sobre os pilares dos direitos fundamentais. É crucial, então, visualizar qual - e como - é a eficácia dos direitos fundamentais na relação de emprego.

\subsection{Vinculação dos particulares aos direitos fundamentais}

\subsubsection{Contextualização do problema}

$\mathrm{Na}$ configuração clássica, o sujeito passivo dos direitos fundamentais era exclusivamente o Estado. Para DIMOULIS e MARTINS, aliás, o próprio conceito de direitos fundamentais abrangeria essa nota característica. Segundo esses autores, os direitos fundamentais são “direitos público-subjetivos de pessoas (físicas ou jurídicas), contidos em dispositivos constitucionais e, portanto, que encerram caráter normativo supremo dentro do Estado, tendo como finalidade limitar o exercício do poder estatal em face da liberdade

\footnotetext{
${ }^{57}$ Vide tópico 4.3, infra.

${ }^{58}$ Entre os quais BELTRAN (2002, pp. 195-198) e LAFER (1988, p. 131).

${ }^{59} 2003$, p. 571.
} 
individual" ${ }^{, 60}$. Note-se que, nesse conceito, um tanto restritivo, somente o Estado pode ser destinatário direto das normas definidoras de direitos fundamentais ${ }^{61}$.

Os direitos do homem eram direitos de defesa dos cidadãos contra a atuação abusiva do Estado (na primeira geração) e direitos a prestações devidas pelo Estado (na segunda geração). Até por causa disso, parte da doutrina cunhou a expressão direitos públicos subjetivos, pois eram direitos exigíveis pelos cidadãos sempre em face do Estado.

Assim é, por exemplo, a configuração do direito de liberdade e de seus desdobramentos $\left(\mathrm{CF}\right.$, art. $\left.5^{\circ}\right)$. Trata-se de comandos dirigidos ao Estado, para que não se intrometa na locomoção das pessoas, não lhes proíba a reunião e a manifestação de ideias, e assim por diante.

No tocante aos direitos sociais a configuração primária não é diferente. $\mathrm{O}$ direito a prestações positivas, talvez com mais razão ainda, é exigível em face do Estado, obrigado a garantir a manutenção de condições de vida digna às pessoas. Assim o direito fundamental à saúde, por exemplo, cuja realização incumbe precipuamente ao Estado $(\mathrm{CF}$, art. 196).

O problema, portanto, incide em analisar as influências das normas de direitos fundamentais nas relações entre particulares, a despeito da configuração clássica desses direitos, a qual se mostrou insuficiente para resolver os problemas sociais contemporâneos.

As questões que se apresentam, então, são estas: (a) seriam exigíveis os direitos fundamentais em face de particulares também? (b) Estariam os particulares, ou alguns deles, vinculados à realização dos direitos fundamentais? (c) Em caso de resposta positiva, como seria operada essa eficácia dos direitos fundamentais nas relações privadas?

\footnotetext{
${ }^{60} 2011$, p. 49.

61 De forma semelhante, Alexandre de MORAES entende que "o importante é realçar que os direitos humanos fundamentais relacionam-se diretamente com a garantia de não-ingerência do Estado na esfera individual e a consagração da dignidade humana" (2007, p. 21).
} 
Mostra-se crucial, no âmbito deste trabalho, uma tomada de posição pela construção da eficácia dos direitos fundamentais nas relações entre particulares. No tópico seguinte essa discussão será mais aprofundada.

\subsubsection{Fundamentos da vinculação dos particulares}

É preciso, antes qualquer outra coisa, responder à seguinte pergunta: é necessária a eficácia dos direitos fundamentais nas relações privadas? Esse questionamento (o porquê da vinculação de particulares a direitos fundamentais) remete à crítica baseada na solidez e suficiência do direito privado para resolver conflitos em relações jurídicas entre particulares.

Sendo impossível eximir-se à tomada de posição no âmbito desse tema, afirma-se a hipótese de que a eficácia dos direitos fundamentais nas relações entre particulares não apenas é necessária, como também é inevitável do ponto de vista do direito positivo ${ }^{62}$.

Em primeiro lugar, a sociedade contemporânea é marcada pelo protagonismo do chamado poder privado, ou seja, o poder exercido por pessoas privadas no seio da coletividade. Com efeito, as relações são quase todas "de massa", isto é, produzem-se bens e serviços em cadeia, a venda desses bens e serviços é feita também em massa, para um público amorfo e não particularizado; finalmente, os problemas decorrentes dessa produção e desse mercado também são resolvidos (quando são resolvidos!) segundo a mesma lógica, ou seja, em massa, coletivamente ${ }^{63}$. Sequer se poderia falar, verdadeiramente, em relações intersubjetivas, pois de um lado figura um sujeito,

62 Segundo Wilson STEINMETZ, "é preciso enfatizar que a vinculação dos particulares a direitos fundamentais, além de ser uma imposição da constituição, é um instrumento socialmente necessário para a preservação e promoção dos direitos fundamentais ante as transformações, sobretudo no plano das relações de poder, das sociedades capitalistas contemporâneas" (STEINMETZ, Wilson. A Vinculação dos Particulares a Direitos Fundamentais. São Paulo: Malheiros, 2004, p. 83).

63 “Assim, com a devida valorização dada às demais espécies de interesse, em vista do advento da sociedade de massas, vem surgindo uma crescente necessidade de revisão dos mais diversos modelos jurídicos. Tal fenômeno tem tido reflexos muito sensíveis, especialmente no que concerne à busca de novas soluções no plano do processo, objetivando a efetiva justiça material a ser obtida, através da atividade jurisdicional." (CORREIA, Marcus Orione Gonçalves. As ações coletivas o direito do trabalho. São Paulo: Saraiva, 1994, p. 23). 
geralmente uma corporação, e de outro lado não se tem um sujeito propriamente dito, e sim a coletividade dos contratantes da corporação - trabalhadores e consumidores. Esses contratantes aderem às condições pensadas, estipuladas e formalizadas pela corporação, sem ter, na maioria dos casos, qualquer prerrogativa de estabelecer suas próprias condições ou cláusulas de seus interesses.

Aliás, até mesmo as tentativas de solução dos problemas desse mercado são fixadas pelas corporações: não raro se veem empresas que aceitam reclamações apenas pelo canal de autoatendimento na internet, ou pelo telefone, outras vezes o cancelamento de determinado serviço não pode ser feito por telefone (mesmo quando a compra foi feita por esse meio), apenas pessoalmente, em horário prefixado, e assim por diante.

Não é difícil perceber, à vista desses dados, que existem pessoas privadas dotadas de uma primazia tal em suas relações com outros particulares que, por isso mesmo, desequilibram a visão da relação jurídica privada tradicional, regida pelo direito privado clássico, fundado na igualdade formal e na autonomia privada ${ }^{64}$. São relações jurídicas assimétricas, desiguais, em que um sujeito maneja, de acordo com seus interesses, aspectos próprios dos direitos fundamentais das pessoas que com ele se relacionam ${ }^{65}$.

Há corporações que têm a seu alcance a violação da privacidade e da intimidade das pessoas, como as empresas de telefonia, por exemplo. Outras têm plena possibilidade de desconsiderar sigilos fiscais e financeiros, como os bancos. Concessionárias de serviços públicos como o fornecimento de água e energia elétrica, por sua vez, têm em suas mãos a própria sobrevivência de famílias inteiras.

\footnotetext{
64 “Refletindo sobre essa situação [as barreiras ao acesso à justiça], é de se esperar que os indivíduos tenham maiores problemas para afirmar seus direitos quando a reivindicação deles envolva ações judiciais por danos relativamente pequenos, contra grandes organizações.” (CAPPELLETTI e GARTH, 1988, p. 28).

65 Para STEINMETZ, "a sociedade capitalista desenvolvida, com um sistema de produção e consumo em escala, exigiu e exige uma sistemática de contratação em massa (contratos de massa), funcional e eficiente. Daí por que há muito prevalecem os contratos estandardizados, com destaque para os contratos de adesão. Os contratos standard representam uma das mais fortes restrições à liberdade contratual. Neles, o princípio da liberdade contratual reduz-se, praticamente, à liberdade de escolher entre contratar e não contratar. Há exíguo espaço - e, por vezes, nenhum espaço - para o exercício da liberdade de discutir e determinar o conteúdo e os efeitos do contrato e, nos casos de monopólios e de oligopólios econômicos de certos bens e serviços (e. g. água, energia elétrica, telefonia), até mesmo para o exercício da liberdade de escolher com quem contratar". (2004, p. 194-195, grifo no original). Cf. sobre o assunto, também, ROMITA, 2012, p. 200.
} 
Daí a razão pela qual o poder privado, característico da sociedade de massa contemporânea, atrai a incidência das normas de direitos fundamentais. Porque se vê hoje um fenômeno semelhante ao que ocorreu no século XVIII, na Europa, em relação ao poder absoluto do monarca: hoje, a sociedade reclama a limitação dos poderes privados, de forma comparável à reivindicação de limitação do poder político do Estado absolutista da parte final da era moderna ${ }^{66}$.

Eis, então, o fundamento da necessidade de vinculação dos particulares aos direitos fundamentais: os direitos fundamentais funcionam nas relações particulares como limites ao poder privado e tutelam os interesses das pessoas que não estão em condições de fazer valer seus direitos por meio do exercício da autonomia privada.

Mas não é apenas esse o fundamento da vinculação dos particulares aos direitos fundamentais. Além do papel de criar situações de direitos subjetivos, as normas de direitos fundamentais têm a natureza, também, de princípios fundamentais do ordenamento jurídico-constitucional. É a denominada dimensão objetiva dos direitos fundamentais, em cotejo com a anterior, a dimensão subjetiva ${ }^{67}$.

Pela dimensão subjetiva, os direitos fundamentais geram para os sujeitos posições de primazia, isto é, de exigibilidade de comportamentos ou prestações. É a noção clássica de direito subjetivo, no sentido de faculdade de exigir o cumprimento de obrigação por parte do devedor. A dimensão subjetiva é a usada como fundamento jurídico quando uma pessoa ingressa em juízo com pretensão derivada diretamente da norma definidora de direito fundamental. De fato, não há maiores problemas para a compreensão dessa dimensão, que é a natureza básica do que se entende por direito ${ }^{68}$.

\footnotetext{
${ }^{66}$ A "teoria dos direitos fundamentais como limites ao poder carece, em parte, de atualidade quando reduz o fenômeno do poder somente ao poder do Estado", pois "há muito o Estado não é o único detentor de poder talvez nunca tenha sido o único. No mundo contemporâneo, pessoas e grupos privados não só detêm poder político, econômico e ideológico como também desenvolvem lutas de e pelo poder" (STEINMETZ, 2004, p. $85)$.

${ }^{67}$ MENDES, 2004, p. 119.

${ }^{68}$ Cf., entre outros, DIMOULIS e MARTINS, 2011, p. 117.
} 
Além dessa dimensão subjetiva, os direitos fundamentais têm uma assim chamada dimensão objetiva. Nessa perspectiva, eles constituem valores básicos da ordem jurídica $^{69}$ e, por isso, geram diretrizes para a aplicação do direito, constitucional e infraconstitucional ${ }^{70}$. Dito de outro modo, os direitos fundamentais são verdadeiros parâmetros de interpretação e aplicação de todas as normas jurídicas, constitucionais e infraconstitucionais.

De fato, normas como a que consagra a igualdade de todos perante a lei e veda a discriminação $\left(\mathrm{CF}\right.$, art. $5^{\circ}$, caput), a que exalta a dignidade da pessoa como fundamento da República (art. $1^{\circ}$, III), a que estabelece a função social da propriedade (art. $5^{\circ}$, XXIII), a que veda a pena por crime não previsto em lei formal e anterior à conduta (art. $5^{\circ}$, XXXIX), ou a que garante direitos sociais como educação, saúde, moradia e alimentação (art. $6^{\circ}$, caput), não são apenas explicitações de direitos subjetivos, mas sim verdadeiros princípios do ordenamento jurídico. Tais princípios têm, entre outras, as funções de preencher axiologicamente o conteúdo de cláusulas gerais incluídas em normas infraconstitucionais (como a boa fé ${ }^{71}$, os bons costumes e a função social do contrato ${ }^{72}$, por exemplo) e orientar a interpretação das leis e demais normas de natureza ordinária.

\footnotetext{
69 "Os direitos fundamentais como sistema de valores regem, como decisão constitucional básica, todos os âmbitos do direito". "O caráter jurídico-objetivo dos direitos fundamentais, tal como enunciado pelo Tribunal Constitucional alemão, é produto de uma teoria axiológica dos direitos fundamentais. Para essa perspectiva teórica, os direitos fundamentais são valores objetivos da comunidade constitucionalizados." (STEINMETZ,
} 2004, p. 107).

70 DIMOULIS e MARTINS, 2011, p. 118-119. Por sua vez, STEINMETZ afirma que "Eficácia interpretativa é a propriedade que as normas constitucionais - como normas-regra e, sobretudo, como normas-princípio - têm de exercer a função de cânones de interpretação dos enunciados lingüísticos que veiculam normas de direito infraconstitucional ou, em outros termos, de ser pauta, diretriz, referência e balizamento da interpretação infraconstitucional." (2004, p. 127, com grifo no original).

${ }^{71}$ BARACAT, Eduardo Milléo. A boa-fé no direito individual do trabalho. São Paulo, LTr, 2003, p. 67-68. Cf. também DINIZ, 2003, p. 37-38.

72 A função social da propriedade tem ainda outro desdobramento que é a função social da empresa: "Substituindo aquela visão da empresa calcada em fins individuais e liberais descontextualizados do sistema jurídico nacional e da própria essência do Estado Social e Democrático de Direito, obtém-se como regra não mais como exceção - uma natural restrição ao uso, gozo, posse e gerência da empresa como entidade jurídica e propriedade que é, exigindo-lhe, a partir de então, uma responsabilidade social que recai tanto sobre as consequências de seus atos e funções internas - sobrevivência e continuidade -, como também sobre as externas - organização da produção e abastecimento -, ambas necessariamente fundamentadas e orientadas pelos princípios da equidade, da boa fé e da proporcionalidade, de modo a temperar e a conformar a autonomia privada [...].” (BRANCO, 2007, p. 79). Sobre o tema, cf. também SIMÓN (2000, p. 118-119). 
Essa função, decorrente da chamada eficácia irradiante dos direitos fundamentais $^{73}$, não pode ser relegada a segundo plano, e é nesse sentido que se sustenta ser inevitável a vinculação dos particulares aos direitos fundamentais; nem que seja apenas na perspectiva da eficácia irradiante - embora seja conveniente antecipar que isso não é tudo. Não seria concebível um direito privado de todo afastado das disposições constitucionais pertinentes aos direitos fundamentais, em sua dimensão objetiva.

Cumpre observar, nesse contexto, que o direito privado tem caminhado exatamente na direção do que se vem de sustentar. Voltando-se os olhos para a legislação e dogmática brasileiras no âmbito do direito privado, desde as duas décadas finais do século XX, não há como passar despercebida a característica marcantemente social (isto é, menos individualista) dos institutos básicos do direito civil.

O Código Civil brasileiro de 2002 encampou ideias como a função social do contrato (art. 421), relativizou a autonomia privada em institutos como a lesão e o estado de perigo como vícios do negócio jurídico (arts. 156 e 157) e previu em várias ocasiões a aplicação e interpretação do direito segundo cláusulas gerais, de conteúdo indeterminado (tais como a boa fé objetiva, por exemplo: art. 422). Tudo a aproximar, de certa forma, a regulação geral do direito privado da eficácia irradiante dos direitos fundamentais. E a doutrina não demorou a perceber a característica social do novo Código Civil, em comparação com o individualismo exacerbado do diploma anterior, o Código Civil de 1916.

Além do Código Civil, atua no mesmo sentido a Lei 8.078, de 1990, que instituiu o Código de Proteção e Defesa do Consumidor (CDC), a regular relações que, a despeito de essencialmente privadas, são notadamente assimétricas, as relações de consumo. E o legislador o fez com um diploma repleto de normas cogentes, de ordem pública, tendentes à proteção jurídica da parte mais fraca economicamente: o consumidor de bens e serviços na sociedade de massas. Aliás, a elaboração dessa lei ordinária era um mandamento do constituinte de 1988 (CF, art. 5 XXXII; ADCT, art. 48), o que demonstra

\footnotetext{
${ }^{73}$ Sobre a chamada eficácia irradiante, cf., entre outros, ROMITA, 2012, p. 199; e MARINONI, 2008, p. 132-133. Por outro lado, e embora não seja conveniente expender uma análise exaustiva da dogmática dos direitos fundamentais, ressalte-se que há uma crítica de Robert ALEXY a respeito da insuficiência da tese de irradiação dos direitos fundamentais no contexto da eficácia horizontal (Teoria dos direitos fundamentais. 2 ed. Tradução de Virgílio Afonso da Silva. São Paulo: Malheiros, 2011, p. 524-528).
} 
a imbricação sólida entre direito privado e direitos fundamentais, e a forte influência exercida por estes sobre aquele.

Em suma, é preciso deixar claro que o direito privado contemporâneo já não é aquele direito privado do século XIX e início do século XX, baseado na sacralidade da autonomia da vontade e da igualdade formal. Tanto o direito civil propriamente dito quanto outras disciplinas do direito privado (como o direito do consumidor, o direito empresarial e o direito de família) têm hoje seus fundamentos fincados nos direitos fundamentais, vistos como princípios ordenadores do sistema jurídico.

Dúvidas não devem restar, então, de que os direitos fundamentais possuem eficácia nas relações entre particulares ${ }^{74}$. A próxima questão a tratar diz respeito ao modo pelo qual se dá essa eficácia, e é centrada no debate envolvendo as teorias da eficácia mediata e da eficácia imediata dos direitos fundamentais nas relações entre particulares.

\subsubsection{Modos de vinculação dos particulares aos direitos fundamentais}

Existem diferentes teorias que buscam explicar o modo de aplicação das normas de direitos fundamentais nas relações entre particulares. Em razão dos limites do tema deste trabalho, não é necessário, e mesmo conveniente, aprofundar e exaurir o estudo de todas as teorias ${ }^{75}$. Em síntese, pode-se dizer que há duas teses principais, em torno das quais gravitam os entendimentos doutrinários mais consolidados: (a) a teoria da eficácia imediata dos direitos fundamentais nas relações privadas, e (b) a teoria da eficácia mediata, isto é, indireta, dos direitos fundamentais nas relações privadas, mediação essa feita primordialmente pela intervenção do legislador infraconstitucional ${ }^{76}$, mas também pelo Judiciário.

\footnotetext{
${ }^{74}$ Segundo MENDES, da vinculação da jurisdição aos direitos fundamentais "resulta para o Judiciário não só o dever de guardar estrita obediência aos chamados direitos fundamentais de caráter judicial, mas também o de assegurar a efetiva aplicação do direito, em especial dos direitos fundamentais, seja nas relações entre os particulares e o Poder Público, seja nas relações tecidas exclusivamente entre particulares” (2004, p. 118).

75 Até porque, nas palavras de MENDES, “a discussão sobre a aplicação dos direitos fundamentais às relações privadas está muito longe de assumir contornos dogmáticos claros” (2004, p. 130).

${ }^{76}$ SARLET, 2009, p. 396-400.
} 
Primeiramente, apresenta-se, em resumo, a teoria da eficácia mediata dos direitos fundamentais nas relações privadas. Essa teoria parte da ideia de que cabe ao legislador intermediar essa relação normativa, traduzindo, por assim dizer, a regra de direito fundamental da constituição para o direito privado. A lei ordinária - e não a norma constitucional - seria a base do regime de direito privado. Nesse contexto, seria desnecessária (quiçá indevida) a fundamentação direta na Constituição de direitos oponíveis a particulares ${ }^{77}$.

A teoria da eficácia mediata mostra a preocupação de evitar que em relações entre particulares seja suscitada solução de um conflito com base diretamente em norma de direito fundamental. Isso poderia gerar o inconveniente de instaurar uma discussão entre dois sujeitos de direitos fundamentais (dois particulares) em torno de uma norma de direito fundamental - facilitando a ocorrência de colisão de direitos fundamentais ${ }^{78}$. Com efeito, recorde-se que, na concepção de direito fundamental como aquele direito que é oponível ao Estado, não há risco de colisão, já que o Estado é sempre devedor de direito fundamental, nunca um titular de direito fundamental. Nas relações entre particulares, entretanto, o risco de haver colisão é, de fato, plausível $^{79}$.

Daí a tese de que cabe ao legislador, em primeiro plano, mediar a aplicação dos direitos fundamentais nas relações privadas. É na previsão expressa em legislação infraconstitucional que se encontrará segurança e certeza quanto à eficácia do direito fundamental entre os particulares, sem a necessidade de buscar fundamentação direta na Constituição Federal.

Por exemplo, cite-se o caso do direito de igualdade entre os empregados da mesma empresa. No aspecto do valor do salário, o empregador deve respeitar requisitos de razoabilidade para estabelecer diferenças entre as remunerações de empregados que tenham funções idênticas. É uma concretização do direito fundamental de igualdade (na vertente da não-discriminação), mas não é necessária a fundamentação direta de uma

\footnotetext{
${ }^{77}$ DIMOULIS e MARTINS, 2011, p. 109; STEINMETZ, 2004, p. 136-143.

78 "O fenômeno da colisão de direitos fundamentais se materializa quando, in concreto, o exercício de um direito fundamental por um titular obstaculiza, afeta ou restringe o exercício de um direito fundamental de um outro titular." (STEINMETZ, 2004, p. 132-133).
}

${ }^{79}$ MENDES, 2004, p. 124-125. 
solução para esse caso na norma constitucional presente no art. $5^{\circ}$ da Constituição Federal. O legislador ordinário verteu, por assim dizer, o direito fundamental para uma regra específica de direito do trabalho (o art. 461 da Consolidação das Leis do Trabalho ${ }^{80}$ ), a qual tem se mostrado suficiente para a regulação dessas situações.

Pode-se compreender, então, que para a teoria da eficácia mediata dos direitos fundamentais nas relações privadas, a vinculação dos particulares a direitos fundamentais é em primeiro lugar uma questão de legislação ${ }^{81}$. Cabe ao legislador a tarefa de estabelecer as vinculações pertinentes dos particulares aos direitos fundamentais, por meio da edição de leis ordinárias específicas a cada tipo de relação jurídica privada.

Todavia, não se pode aceitar um total arbítrio do Legislativo na aferição de conveniência e oportunidade para estabelecer a vinculação dos particulares aos direitos fundamentais. Seria um âmbito tal de discricionariedade que contrariaria as bases do Estado Democrático de Direito. E é justo que se diga: a teoria da eficácia mediata não aceita esse arbítrio.

$\mathrm{Na}$ ausência de concretização legislativa, deverá incidir a mediação estatal por meio do Judiciário. Com efeito, caberá ao juiz estabelecer vinculações privadas a direitos fundamentais, nos casos concretos que lhe forem submetidos, sempre que não existir mediação eficiente por parte da legislação ordinária.

O juiz, por sua vez, tem basicamente (sempre na perspectiva da teoria da eficácia mediata) dois instrumentos para realizar a mediação referida. $O$ primeiro instrumento é a interpretação e aplicação do direito privado segundo os valores objetivos

\footnotetext{
${ }^{80}$ Art. 461. Sendo idêntica a função, a todo trabalho de igual valor, prestado ao mesmo empregador, na mesma localidade, corresponderá igual salário, sem distinção de sexo, nacionalidade ou idade.

$\S 1^{\circ}$. Trabalho de igual valor, para os fins deste capítulo, será o que for feito com igual produtividade e com a mesma perfeição técnica, entre pessoas cuja diferença de tempo de serviço não for superior a dois anos.

$\S 2^{\circ}$. Os dispositivos deste artigo não prevalecerão quando o empregador tiver pessoal organizado em quadro de carreira, hipótese em que as promoções deverão obedecer aos critérios de antigüidade e merecimento.

$\S 3^{\circ}$. No caso do parágrafo anterior, as promoções deverão ser feitas alternadamente por merecimento e por antigüidade, dentro de cada categoria profissional.

$\S 4^{\circ}$. O trabalhador readaptado em nova função, por motivo de deficiência física ou mental atestada pelo órgão competente da Previdência Social, não servirá de paradigma para fins de equiparação salarial.

81 "Para a teoria da eficácia mediata, a eficácia de direitos fundamentais entre particulares é, em primeiro plano, uma tarefa de legislação [...]. Mais precisamente, cabe ao legislador delimitar, ponderar e harmonizar a eficácia de direitos fundamentais e bens constitucionalmente protegidos nas relações entre os particulares". (STEINMETZ, 2004, p. 143)
} 
decorrentes do sistema constitucional de direitos fundamentais. Cabe ao juiz interpretar e aplicar cada disposição legal de direito privado em consonância com os valores concretizados no ordenamento pelos direitos fundamentais constantes da Constituição Federal. Os direitos fundamentais constituem uma constelação de valores e princípios que orientam o intérprete e aplicador do direito privado, no momento em que ele estabelece soluções para litígios concretos. Trata-se da já mencionada eficácia irradiante dos direitos fundamentais, que é em boa medida o instrumento por excelência de aplicação dos direitos fundamentais nas relações privadas - na ótica da teoria da eficácia mediata.

O segundo instrumento que o juiz pode manejar para realizar a mediação e fazer incidir os direitos fundamentais nas relações privadas é o que se tem denominado preenchimento axiológico ${ }^{82}$ de cláusulas gerais ${ }^{83}$ do direito privado com o conteúdo dos direitos fundamentais.

Cláusulas gerais e de conteúdo indeterminado, tais como "função social do contrato", "boa fé objetiva", "bons costumes", entre outras, funcionariam como válvulas de introdução, no sistema de direito privado, dos conteúdos de direitos fundamentais que devam reger relações entre particulares. Por meio do preenchimento dessas cláusulas, o juiz realiza a eficácia dos direitos fundamentais, de forma indireta ou mediata. Não há, como se vê, fundamentação direta da solução da lide privada em normas de direitos fundamentais.

A teoria da eficácia mediata dos direitos fundamentais nas relações privadas gera, entretanto, alguns problemas. O principal deles parece ser a excessiva dependência da boa vontade do legislador ordinário na concretização das normas de direitos fundamentais.

\footnotetext{
${ }^{82}$ STEINMETZ, 2004, p. 145.

83 Para STEINMETZ, "no direito privado, as cláusulas gerais são havidas como recurso interpretativoaplicativo, que o legislador põe à disposição do juiz, para a restrição, in concreto, da autonomia privada e do exercício de direitos ou interesses subjetivos legais." (2004, p. 147). Por sua vez, Ana Paula de BARCELLOS salienta que "ao utilizar conceitos jurídicos indeterminados e cláusulas gerais, o legislador acaba transferindo a delimitação do sentido e alcance dos enunciados normativos para o intérprete." (Ponderação, racionalidade e atividade jurisdicional. Rio de Janeiro: Renovar, 2005, p. 13).
} 
A realidade brasileira dos últimos anos não recomenda essa confiança na celeridade do Poder Legislativo ${ }^{84}$. Mesmo diante de expressa determinação do constituinte originário, a mora legislativa já chegou a patamares emblemáticos. Para ficar em apenas um exemplo, desde 1988 a vontade constitucional era expressa no sentido de que o aviso prévio, como direito dos trabalhadores, fosse proporcional ao tempo de serviço (art. $7^{\circ}$, XXI). Não menos do que vinte e três anos se passaram, até que veio a lume a Lei 12.506/2011 (publicada no Diário Oficial da União em 13 de outubro de 2011), a regulamentar o referido dispositivo. Durante esse interregno, o aviso prévio proporcional foi, na prática, letra morta contida em norma constitucional, situação bastante grave, em especial por se tratar de norma incluída no rol dos direitos fundamentais.

Além desse, outro aspecto negativo da teoria da eficácia mediata é a verdadeira submissão das normas constitucionais, definidoras de direitos fundamentais, a regras infraconstitucionais de natureza ordinária. Há, pelo menos, dois problemas teóricos nesse efeito: a) o resgate da separação estanque entre direito público e direito privado, a confrontar a evolução da Ciência do Direito no sentido da superação dessa dicotomia; b) a inversão da ordem hierárquica fundamental do ordenamento jurídico, pela qual são as normas constitucionais as que detêm a hierarquia máxima no sistema, a elas devendo as leis ordinárias se conformar, não o contrário.

Na síntese oportuna de Wilson STEINMETZ ${ }^{85}$,

Condicionar, de forma exclusiva, a eficácia de normas de direitos fundamentais entre particulares à mediação legislativa e à mediação judicial interpretativa e aplicativa dos textos de normas de direito privado - de modo especial, as cláusulas gerais - é propor a 'legalização' dos direitos fundamentais, é substituir o princípio da constitucionalidade pelo princípio da legalidade. Mais perigosa do que a 'jusfundamentalização' do direito civil é a 'civilização' ('infraconstitucionalização') dos direitos fundamentais.

\footnotetext{
84 A propósito, SARLET, ao tratar do princípio da proibição de retrocesso social, afirma que "negar reconhecimento ao princípio da proibição de retrocesso social significaria, em última análise, admitir que os órgãos legislativos [...] dispõem do poder de tomar livremente suas decisões mesmo em flagrante desrespeito à vontade expressa do Constituinte" (SARLET, I. W. Algumas notas a respeito dos direitos fundamentais sociais e a proibição de retrocesso: desafios e perspectivas. Cadernos da Amatra IV, ano V, n. 13. Porto Alegre: HS Editora, 2010, p. 32).
}

85 2004, p. 156. 
Assim, a teoria da aplicação mediata dos direitos fundamentais nas relações particulares não parece contribuir para a máxima eficácia desses direitos ${ }^{86}$.

Já a teoria da eficácia imediata (ou direta) dos direitos fundamentais nas relações privadas sustenta que não é imprescindível a mediação estatal, legislativa ou judiciária, para que os direitos fundamentais possam ser aplicados nas relações jurídicas privadas. Essa teoria mostra-se inegavelmente mais atenta à preocupação constitucional de máxima eficácia dos direitos fundamentais.

Com efeito, não se harmoniza com a preocupação de máxima eficácia a afirmação de que necessariamente deve haver uma mediação legislativa ou judicial para que os direitos fundamentais possam ser aplicados em relações privadas. Não tem sentido essa exigência, a se partir da ideia de que a posição de primazia hierárquica é a das normas de direitos fundamentais, não das normas infraconstitucionais.

Tem-se objetado, contra a teoria da eficácia imediata, que a aplicação direta das normas de direitos fundamentais em relações privadas terminaria por esvaziar de conteúdo o direito privado. Ainda, argumenta-se que pode ser criada uma situação na qual se contraponham dois titulares de direitos fundamentais em rota de colisão.

Ambas as objeções, contudo, apesar de bem fundamentadas e defendidas, não procedem. Em primeiro lugar, o direito privado não precisa de um "isolamento" do direito constitucional para sobreviver. Não são (o direito constitucional e o direito privado) compartimentos estanques; em certa medida, não podem abrir mão de uma convivência prática harmoniosa, a fim de fazer com que o ordenamento jurídico consiga regular todas as áreas normativas de forma razoável. Todavia, essa convivência harmoniosa não deve obscurecer a premissa fundamental de qualquer análise jurídica (pelo menos as análises que tenham por objeto o direito positivo brasileiro): as normas constitucionais, em especial aquelas que definem direitos fundamentais, têm posição hierárquica superior no ordenamento, em relação às regras infraconstitucionais de direito privado.

\footnotetext{
${ }^{86}$ Vejam-se, a propósito, as considerações de DIMOULIS e MARTINS sobre o exemplo pertinente à aplicação do princípio da igualdade em matéria de remuneração, no âmbito da relação de emprego: "Em nossa opinião, prevalece a liberdade do empregador que pode estabelecer os critérios de remuneração de seus funcionários, tal como alguém escolhe seus amigos com critérios pessoais sem que seja obrigado a tratar 'igualmente' ou 'sem distinção de qualquer natureza' todas as pessoas.” (2011, p. 113)
} 
Em segundo lugar, não é correto sustentar que a teoria da eficácia imediata levaria à ruína da função legislativa do Estado na área do direito privado. $\mathrm{O}$ argumento é injustificadamente extremista ${ }^{87}$. Quando existir regulação legislativa infraconstitucional que efetue adequadamente a transposição do conteúdo de direito fundamental ao campo específico de direito privado, não há razão para afastar a validade e eficácia dessa legislação. Dito de outro modo: nada obsta a que se dê preferência à ponderação efetuada de forma legítima e constitucionalmente adequada pelo legislador ordinário. Nessa hipótese, pode mostrar-se desnecessário o recurso à fundamentação direta na Constituição Federal para obter a eficácia do direito fundamental; e não parece haver problema teórico algum nisso.

Por exemplo, pode-se recordar a já citada norma do art. 461 da CLT, que regula a igualdade de remuneração em casos de trabalho de igual valor na mesma empresa. Trata-se de uma autêntica mediação legislativa, que concretiza de forma constitucionalmente adequada o direito fundamental de igualdade no âmbito do direito do trabalho. É de fácil observação empírica que a norma infraconstitucional tem sido bastante à solução de ampla gama de casos concretos envolvendo o tema, o que torna desnecessário o recurso à fundamentação direta na norma constitucional do direito fundamental de igualdade. Mas essa conclusão não sustenta o argumento para elidir a teoria da eficácia imediata.

De fato, há casos em que não existe a mediação legislativa, e pode-se assumir que igualmente não existam cláusulas gerais que amparem a mediação judicial por preenchimento axiológico; é nessas hipóteses que se revela a importância da teoria da eficácia imediata ${ }^{88}$.

\footnotetext{
${ }^{87}$ Aliás, com Wílson STEINMETZ, "registre-se que nenhum teórico da eficácia imediata propõe que o juiz e os tribunais sobreponham, em matéria de direitos fundamentais, suas ponderações ex constitutione às ponderações do legislador. Quando há regulação legislativa específica e conforme à Constituição e às normas de direitos fundamentais, então deve prevalecer, no caso concreto, a aplicação da norma infraconstitucional" (2004, p. 268).

${ }^{88}$ Até porque "se o legislador ordinário não cria regulações normativas instituindo supostos fáticos específicos e consequiências jurídicas determinadas com vistas à demarcação e harmonização dos 'espaços jusfundamentais' entre particulares e, em um determinado caso concreto, a solução judicial via cláusulas gerais não é possível, então há apenas duas alternativas: ou se nega a eficácia, sem mais, ou se admite a eficácia imediata" (STEINMETZ, 2004, p. 174).
} 
O Supremo Tribunal Federal proferiu interessante julgamento envolvendo essa questão, em que assentou o entendimento pela vinculação direta dos particulares às normas de direitos fundamentais. A ementa do acórdão tem o seguinte teor:

SOCIEDADE CIVIL SEM FINS LUCRATIVOS. UNIÃO BRASILEIRA DE COMPOSITORES. EXCLUSÃO DE SÓCIO SEM GARANTIA DA AMPLA DEFESA E DO CONTRADITÓRIO. EFICÁCIA DOS DIREITOS FUNDAMENTAIS NAS RELAÇÕES PRIVADAS. RECURSO DESPROVIDO. I. EFICÁCIA DOS DIREITOS FUNDAMENTAIS NAS RELAÇÕES PRIVADAS. As violações a direitos fundamentais não ocorrem somente no âmbito das relações entre o cidadão e o Estado, mas igualmente nas relações travadas entre pessoas físicas e jurídicas de direito privado. Assim, os direitos fundamentais assegurados pela Constituição vinculam diretamente não apenas os poderes públicos, estando direcionados também à proteção dos particulares em face dos poderes privados. II. OS PRINCÍPIOS CONSTITUCIONAIS COMO LIMITES À AUTONOMIA PRIVADA DAS ASSOCIAÇÕES. A ordem jurídico-constitucional brasileira não conferiu a qualquer associação civil a possibilidade de agir à revelia dos princípios inscritos nas leis e, em especial, dos postulados que têm por fundamento direto o próprio texto da Constituição da República, notadamente em tema de proteção às liberdades e garantias fundamentais. O espaço de autonomia privada garantido pela Constituição às associações não está imune à incidência dos princípios constitucionais que asseguram o respeito aos direitos fundamentais de seus associados. A autonomia privada, que encontra claras limitações de ordem jurídica, não pode ser exercida em detrimento ou com desrespeito aos direitos e garantias de terceiros, especialmente aqueles positivados em sede constitucional, pois a autonomia da vontade não confere aos particulares, no domínio de sua incidência e atuação, o poder de transgredir ou de ignorar as restrições postas e definidas pela própria Constituição, cuja eficácia e força normativa também se impõem, aos particulares, no âmbito de suas relações privadas, em tema de liberdades fundamentais. III. SOCIEDADE CIVIL SEM FINS LUCRATIVOS. ENTIDADE QUE INTEGRA ESPAÇO PÚBLICO, AINDA QUE NÃO-ESTATAL. ATIVIDADE DE CARÁTER PÚBLICO. EXCLUSÃO DE SÓCIO SEM GARANTIA DO DEVIDO PROCESSO LEGAL. APLICAÇÃO DIRETA DOS DIREITOS FUNDAMENTAIS À AMPLA DEFESA E AO CONTRADITÓRIO. As associações privadas que exercem função predominante em determinado âmbito econômico e/ou social, mantendo seus associados em relações de dependência econômica e/ou social, integram o que se pode denominar de espaço público, ainda que nãoestatal. A União Brasileira de Compositores - UBC, sociedade civil sem fins lucrativos, integra a estrutura do ECAD e, portanto, assume posição privilegiada para determinar a extensão do gozo e fruição dos direitos autorais de seus associados. A exclusão de sócio do quadro social da UBC, sem qualquer garantia de ampla defesa, do contraditório, ou do devido processo constitucional, onera consideravelmente o recorrido, o qual fica impossibilitado de perceber os direitos autorais relativos à execução de suas obras. A vedação das garantias constitucionais do devido processo legal acaba por restringir a própria liberdade de 
exercício profissional do sócio. O caráter público da atividade exercida pela sociedade e a dependência do vínculo associativo para o exercício profissional de seus sócios legitimam, no caso concreto, a aplicação direta dos direitos fundamentais concernentes ao devido processo legal, ao contraditório e à ampla defesa (art. $5^{\circ}$, LIV e LV, CF/88). IV. RECURSO EXTRAORDINÁRIO DESPROVIDO (STF-RE 201819/RJ, rel. Min. ELLEN GRACIE, rel. p/ acórdão Min. GILMAR MENDES, j. 11/10/2005, $2^{\mathrm{a}}$ T., DJ 27/10/2006, p. 64).

Os trechos em destaque evidenciam que, no entender do STF, as normas consagradoras de direitos fundamentais têm aplicação direta nas relações entre particulares e influenciam o espaço de autonomia privada das pessoas, espaço esse que não está infenso aos conteúdos dos direitos fundamentais previstos na Constituição Federal ${ }^{89}$.

Finalmente, a possibilidade de colisões de direitos fundamentais não pode ser negada. Mas a existência de colisão não representa nenhuma fissura do ponto de vista da integridade do sistema jurídico, até porque o próprio sistema conta com técnica de solução adequada, baseada na ponderação e na regra da proporcionalidade ${ }^{90}$.

Cumpre salientar, para fechar este tópico, que parte da doutrina defende a vinculação direta (aplicação imediata) dos particulares a direitos fundamentais quando preenchido o requisito da notável diferença de poder entre os particulares envolvidos na relação jurídica em exame ${ }^{91}$. Isto é, quando na relação privada se encontrar uma diferença de poder acentuada, existirá entre os sujeitos verdadeira relação de subordinação, semelhante à que existe entre um particular e o Estado - e não uma relação de coordenação, característica da relação jurídica privada clássica.

\footnotetext{
${ }^{89} \mathrm{O}$ acórdão do STF evidencia a aplicação do direito fundamental ao devido processo legal em seu sentido substancial, no âmbito das relações privadas (NERY JÚNIOR, Nélson. Princípios do processo civil na Constituição da República. 3 ed. São Paulo: RT, 1996, pp. 35-38). Trilhando raciocínio semelhante, o Tribunal Superior do Trabalho, por sua Seção de Dissídios Coletivos, decidiu pela invalidade de uma cláusula de convenção coletiva de trabalho que excluía do direito ao benefício da cesta básica os empregados que estivessem em período de experiência. Entendeu-se que "a exclusão dos trabalhadores em contrato de experiência não se coaduna princípio constitucional do art. $3^{\circ}$, IV, in fine, da CF/88" (Tribunal Superior do Trabalho. Recurso Ordinário 020260-19-2010-5-04-0000, SDC, Rel. Min. Kátia Magalhães Arruda, data de julgamento 9.10.2012, cfr. Informativo/TST 025).

${ }^{90}$ Sobre a regra (ou princípio, ou postulado) da proporcionalidade, cf., entre outros: ÁVILA, Humberto. Teoria dos princípios: da definição à aplicação dos princípios jurídicos. 12 ed. São Paulo: Malheiros, 2011, p. 173-188; e SILVA, Virgílio Afonso da. Direitos fundamentais: conteúdo essencial, restrições e eficácia. 2 ed. São Paulo: Malheiros, 2010, p. 167-182.
}

${ }^{91}$ SARLET, 2009, p. 397. 
Nessa relação jurídica desigual haverá, para aplicação das normas constitucionais de direitos fundamentais, razões similares às que existem nas relações de direito público. Com efeito, a preocupação do sistema jurídico com o abuso de poder deve incidir tanto para limitar o poder do Estado quanto para limitar o poder de pessoas privadas que estejam numa posição tal de supremacia social que possam ferir diretamente direitos fundamentais alheios.

\subsubsection{Direito do trabalho e vinculação dos particulares aos direitos fundamentais}

A função deste tópico é a de reforçar a conclusão de que, no direito do trabalho, a eficácia privada dos direitos fundamentais é direta e imediata. Com efeito, se dúvida existir quanto ao modo de eficácia dos direitos fundamentais nas relações privadas de outros meandros jurídicos, é preciso não perder de vista que, no direito do trabalho, em razão de suas características essenciais, essa eficácia deve ser imediata.

Em primeiro lugar, a eficácia imediata se justifica em razão da notável diferença de poder entre as partes da relação de emprego. Parece evidente que a diferença de poder existe nas relações entre consumidores e fornecedores, e entre clientes e instituições financeiras; porém, ela existe, por definição, e é ainda mais notável nas relações entre empregados e empregadores.

De fato, a relação de emprego se caracteriza justamente pela subordinação do empregado e pelo poder diretivo do empregador, os quais são vistos como verso e anverso do mesmo fenômeno ${ }^{92}$. A subordinação do empregado ao poder do empregador é nota conceitual da relação jurídica de emprego ${ }^{93}$ (diferentemente do que ocorre na relação de

92 Nesse sentido são as considerações de Otávio Pinto e SILVA (Subordinação, autonomia $e$ parassubordinação nas relações de trabalho. São Paulo: LTr, 2004, p. 16). É interessante também notar que, "contraditoriamente à liberdade de mercado que a empresa reclama em sua relação negocial, a relação com os empregados é dominada pela subordinação destes” (GUEDES, Márcia Novaes. Terror psicológico no trabalho. 3 ed. São Paulo: LTr, 2008, p. 58).

93 “A subordinação ou relação de dependência se pode dizer, é a característica mais importante da relação de emprego" (ALKIMIN, Maria Aparecida. Assédio moral na relação de trabalho. 2 ed. Curitiba: Juruá, 2009, p. 24). Cf. também PAMPLONA FILHO, Rodolfo. O dano moral na relação de emprego. 3 ed. São Paulo: LTr, 2002, p. 92. 
consumo, por exemplo, que não tem a subordinação ou sujeição como nota conceitual). Se assim é, a própria natureza dessa relação jurídica já demonstra o requisito da notável diferença de poder entre os sujeitos, de modo a atrair a vinculação direta dos direitos fundamentais nesse âmbito ${ }^{94}$. Por outras palavras, inexistindo essa diferença de poder (no aspecto jurídico, frise-se), não se estará tratando de verdadeira relação de emprego.

A subordinação do empregado o impele a acatar as ordens dadas pelo empregador no âmbito da execução do serviço e manutenção do meio ambiente do trabalho, mas não se resume a isso. A subordinação traz consigo deveres anexos, por assim dizer, que se imbricam no contrato de trabalho e são mesmo exigidos da parte do patrão: deveres de respeito e educação que, embora devessem ser via de mão dupla, não são. Os empregados não obtêm o mesmo respeito e a mesma educação, com a mesma facilidade, em relação aos patrões, estando estes últimos em posição privilegiada, também nesse aspecto $^{95}$.

Existe uma cultura de submissão, nas relações de trabalho no Brasil. Até mesmo discordar do patrão em quesitos como política e religião não se mostram ações recomendáveis; quando o assunto adentra ao meio ambiente do trabalho, então, a cautela é máxima. Cobrar melhorias ambientais, reivindicar aumentos salariais e outras questões dessa espécie não são condutas tão fáceis de pôr em prática como as cobranças efetuadas pelo empregador acerca da qualidade do serviço, atrasos e faltas de seus empregados. Tudo isso em razão da titularidade do poder privado na relação jurídica de emprego: é o empregador que detém o poder diretivo, o qual implica o dever de sujeição do empregado - a subordinação jurídica. Além, é claro, de razões históricas e culturais que serão mencionadas mais adiante.

\footnotetext{
${ }^{94}$ Perfilhando o mesmo entendimento, LEITE propugna que "como as relações de trabalho subordinado são marcadas pela desigualdade entre os particulares, de um lado o empregador, que detém o poder empregatício (econômico, regulamentar, diretivo e disciplinar), e do outro o empregado, hipossuficiente e vulnerável, parece-nos inegável a plena aplicação da eficácia horizontal dos direitos fundamentais nas relações empregatícias." (2011, p. 39).

95 Para VIANA, "o contrato de trabalho tem algo que, por assim dizer, supera a própria contratualidade: coloca o empregado sob o poder unilateral do empregador, imerso numa atmosfera de subordinação que o acompanha, em certa medida, até fora dos limites da fábrica e da jornada de trabalho" (1996, p. 82).
} 
Entre os aspectos do poder diretivo, cumpre destacar a função essencial desempenhada pelo assim denominado poder disciplinar, pelo qual o empregador tem assegurada a prerrogativa de aplicar punições aos empregados, evidentemente nos termos da lei ${ }^{96}$. O poder disciplinar é uma espécie de garantia da subordinação dos trabalhadores, pois com as ferramentas punitivas o empresário domina as ações dentro da empresa, no tocante ao direcionamento da prestação de serviços e, também, nos aspectos da ordem e obediência no meio ambiente do trabalho.

Pode o empregador, no âmbito do poder disciplinar, valer-se de advertências para punir faltas leves de seus empregados, e da suspensão, para punir faltas de gravidade mais acentuada. As faltas gravíssimas dos trabalhadores são tipificadas em lei (CLT, art. $482^{97}$ ) e acarretam a despedida por justa causa - modalidade de extinção do contrato de trabalho que retira o direito do empregado de receber qualquer verba rescisória, salvo o salário propriamente dito e parcelas cuja aquisição já se tenha aperfeiçoado.

A despedida por justa causa é uma medida de excepcional poder de coerção ${ }^{98}$. A pessoa sempre terá um receio fundado ao receber a ameaça de ser dispensada da empresa por justa causa, pois essa pena não só lhe retirará os direitos rescisórios (agredindo sua integridade financeira) como também poderá, se divulgada, dificultar bastante a obtenção de novo emprego. O manejo da coerção decorrente da possibilidade de dispensa por justa causa coloca o empregador em situação deveras confortável, do ponto de vista da concentração do poder privado.

\footnotetext{
${ }^{96}$ SIMÓN, 2000, p. 107-108.

97 Art. 482. Constituem justa causa para rescisão do contrato de trabalho pelo empregador: a) ato de improbidade; b) incontinência de conduta ou mau procedimento; c) negociação habitual por conta própria ou alheia sem permissão do empregador, e quando constituir ato de concorrência à empresa para a qual trabalha o empregado, ou for prejudicial ao serviço; d) condenação criminal do empregado, passada em julgado, caso não tenha havido suspensão da execução da pena; e) desídia no desempenho das respectivas funções; f) embriaguez habitual ou em serviço; g) violação de segredo da empresa; h) ato de indisciplina ou de insubordinação; i) abandono de emprego; j) ato lesivo da honra ou da boa fama praticado no serviço contra qualquer pessoa, ou ofensas físicas, nas mesmas condições, salvo em caso de legítima defesa, própria ou de outrem; k) ato lesivo da honra e boa fama ou ofensas físicas praticadas contra o empregador e superiores hierárquicos, salvo em caso de legítima defesa, própria ou de outrem; 1) prática constante de jogos de azar. Parágrafo único. Constitui igualmente justa causa para dispensa de empregado, a prática, devidamente comprovada em inquérito administrativo, de atos atentatórios à segurança nacional.
}

98 Entendida a coerção como "o poder de coagir" (OLIVEIRA, Sebastião Geraldo de. Proteção jurídica à saúde do trabalhador. 6 ed. São Paulo: LTr, 2011, p. 41). 
Aliás, em se tratando de dispensa do emprego, em alguns casos sequer é necessário o recurso à ameaça de justa causa para gerar a submissão dos trabalhadores. Em um ordenamento jurídico como o brasileiro, no qual se reconhece, a despeito da norma inserida no art. $7^{\circ}$, inciso I, da CF, o direito potestativo de resilição do contrato de trabalho pelo empregador, sem necessidade de justificação ou explicação ${ }^{99}$, a manutenção financeira da vida do trabalhador e de sua família está de fato nas mãos do empregador. E isso lhe atribui um poder extremo. Mesmo no caso dos empregados de cargos mais altos e bem remunerados, o pavor decorrente da possibilidade de ser despedido - ainda que sem justa causa - chega a comprometer a saúde dos trabalhadores.

Vê-se, assim, que o empregador exerce no contrato de trabalho um poder privado avassalador - muito mais do que seria necessário para configurar a diferença notável de poder entre particulares e atrair, segundo esse entendimento, a eficácia direta dos direitos fundamentais ${ }^{100}$.

No entanto, não bastassem essas circunstâncias, outro fator concorre para a situação privilegiada do empregador: o ordenamento jurídico não lhe impõe, via de regra, a observância de procedimento estruturado para a aplicação das penalidades, mesmo a dispensa por justa causa. Mais uma vez, tem-se campo fértil para o agir inesperado e de certa forma abrupto do empregador. Ele decide aplicar a justa causa ao trabalhador e assim age; pura e simplesmente, deixa-o sem trabalho, sem salário, sem verbas rescisórias e, ainda, sem seguro-desemprego ${ }^{101}$. Cabe ao trabalhador dispensado, se quiser (e se puder!), acionar judicialmente o empregador para discutir a licitude da dispensa. E nesse eventual

\footnotetext{
${ }^{99}$ Segundo Enoque Ribeiro dos SANTOS, “o sistema trabalhista brasileiro favorece os empresários, que possuem ampla liberdade para exercer o seu poder de mando na dispensa de seus empregados, sem quaisquer justificativas". (2009, p. 49).

${ }^{100}$ Realmente, "de nada adiantaria o Estado respeitar o direito à intimidade e à vida privada dos indivíduos, se não houvesse mecanismos que impusessem esse mesmo dever aos empresários, no âmbito das relações laborais" (SIMÓN, 2000, p. 102).

101 O inciso II do art. $7^{\circ}$ da CF prevê o benefício do seguro-desemprego em "caso de desemprego involuntário", cláusula que tem sido interpretada pela doutrina e jurisprudência como excludente da situação de dispensa por justa causa. Ademais, a corroborar essa visão, o art. $2^{\text {o }}$ da Lei 7.998/1990 estipula que o programa de seguro-desemprego destina-se a "prover a assistência financeira temporária ao trabalhador desempregado em virtude de dispensa sem justa causa, inclusive a indireta, e ao trabalhador comprovadamente resgatado de regime de trabalho forçado ou da condição análoga à de escravo" (inciso I).
} 
processo judicial o ônus da demora depõe contra o reclamante, para piorar sua situação já bastante fragilizada $^{102}$.

O raciocínio desenvolvido serve para demonstrar que é mais do que compreensível o estado permanente de sujeição do empregado ao empregador. Os empregados, no ordenamento brasileiro, não têm qualquer segurança no emprego, não têm como saber se e quando poderão ser despedidos, com ou sem justa causa. Não há como negar que esse estado de sujeição, tal como sombra a rondar o meio ambiente do trabalho e a mente dos trabalhadores, os faz medirem suas palavras e calcularem seus comportamentos, de modo a evitar, o mais possível, praticar algo que os desabone na empresa.

É uma significativa restrição à autonomia da vontade dos trabalhadores, que se relaciona aos fundamentos teóricos do direito do trabalho - composto em grande parte de normas cogentes e tutelares dos direitos do empregado, considerados em princípio indisponíveis. Nesse contexto devem ser lidas regras como a que comina pena de nulidade para alterações contratuais que acarretem, "direta ou indiretamente”, prejuízos ao empregado, ainda que ele tenha concordado com a alteração (CLT, art. $468^{103}$ ).

O empregado não tem possibilidade real de discutir em condições de igualdade as cláusulas do contrato de trabalho; aliás, mesmo por ocasião do término do contrato a sujeição econômica ainda se faz presente, o que às vezes leva o trabalhador a assinar "pedido de demissão" para não se ver despedido por justa causa, o que pioraria ainda mais sua situação financeira.

Diante desses argumentos, é possível sedimentar a proposição de que o empregador encontra-se em posição tal de supremacia de poder em face do empregado que

\footnotetext{
102 "Os efeitos dessa delonga [processual], especialmente se considerados os índices de inflação, podem ser devastadores. Ela aumenta os custos para as partes e pressiona os economicamente fracos a abandonar suas causas, ou a aceitar acordos por valores muito inferiores àqueles a que teriam direito." (CAPPELLETTI e GARTH, 1988, p. 20).

${ }^{103}$ CLT, art. 468. Nos contratos individuais de trabalho só é lícita a alteração das respectivas condições por mútuo consentimento, e, ainda assim, desde que não resultem, direta ou indiretamente, prejuízos ao empregado, sob pena de nulidade da cláusula infringente desta garantia. Parágrafo único. Não se considera alteração unilateral a determinação do empregador para que o respectivo empregado reverta ao cargo efetivo, anteriormente ocupado, deixando o exercício de função de confiança.
} 
estará, o primeiro, diretamente vinculado às normas de tutela dos direitos fundamentais do segundo.

Deve o empregador, portanto, respeitar (e fazer respeitar) o direito de liberdade de seus empregados, tratá-los de maneira isonômica ${ }^{104}$, abster-se de violar sua intimidade, e assim por diante. E tais deveres independem de previsão em legislação ordinária, a partir do momento em que se adota a tese da vinculação direta do empregador às normas de direitos fundamentais ${ }^{105}$.

Por fim, não é exagero reforçar a argumentação constatando-se que grande parte dos direitos dos empregados está arrolada no artigo $7^{\circ}$ da Constituição Federal. São, portanto, direitos fundamentais na ótica formal, o que torna evidente sua aplicação direta e imediata na relação de emprego. Não haveria qualquer sentido em se defender a vinculação apenas mediata do empregador aos direitos enunciados nos incisos do artigo $7^{\circ}$ mencionado. Afinal, se esses dispositivos constitucionais não se dirigissem ao empregador diretamente, seriam eles apenas mandados normativos destinados ao Poder Legislativo.

Por essas razões, não deve haver dúvida de que, ao menos no ordenamento jurídico brasileiro, a eficácia horizontal dos direitos fundamentais se dá, no âmbito da relação de emprego, de forma imediata.

\subsection{Processo do trabalho como instrumento de proteção de direitos fundamentais}

\subsubsection{Leitura constitucional do processo do trabalho no Brasil}

O direito do trabalho é permeado, como exposto acima, de regras com matriz constitucional, e nesse âmbito a eficácia dos direitos fundamentais é imediata. Na relação

\footnotetext{
${ }^{104}$ Nesse aspecto se assume a divergência entre o que se vem de sustentar e o posicionamento de DIMOULIS e MARTINS, descrito na nota de rodapé 86, supra.

105 A tese que ora se sustenta não vem senão corroborar o princípio da proteção, que "se refere ao critério fundamental que orienta o Direito do Trabalho, pois este, ao invés de inspirar-se num propósito de igualdade, responde ao objetivo de estabelecer um amparo preferencial a uma das partes: o trabalhador" (PLÁ RODRIGUEZ, Américo. Princípios de direito do trabalho. Trad. Wagner Giglio. 3 ed. São Paulo: LTr, 2000, p. 83).
} 
jurídica de emprego existe uma pessoa fortemente sujeita a outra, no aspecto da subordinação jurídica, a qual gera, muitas vezes, um estado de verdadeira sujeição pessoal. É nesse contexto que se releva a importância do processo do trabalho como instrumento de proteção de direitos fundamentais.

A Constituição Federal estabelece que a competência para processar e julgar os conflitos oriundos da relação de trabalho é da Justiça do Trabalho (art. 114). E o processo do trabalho, regulado basicamente na própria CLT, é o instrumento de que se vale a Justiça do Trabalho para a aplicação concreta do direito material trabalhista aos casos que lhe são submetidos à apreciação ${ }^{106}$.

O direito do trabalho termina por ser aplicado, por assim dizer, mediante as regras procedimentais do processo trabalhista. É preciso consignar, por isso, que o processo do trabalho tem importância fundamental na realização e implementação dos direitos fundamentais dos trabalhadores. E essa afirmação molda o prisma pelo qual o processo do trabalho deve ser visto e estudado ${ }^{107}$.

A premissa que deve ficar clara é: o processo do trabalho tem a missão de tutelar direitos fundamentais. Quando se pleiteia em juízo o pagamento de verbas rescisórias, décimo terceiro salário, FGTS e outras parcelas garantidas no $\operatorname{artigo} 7^{\circ}$ da Constituição Federal, não se faz menos do que requerer tutela jurisdicional a direitos de índole constitucional. Pede-se, pois, a proteção a direitos fundamentais ${ }^{108}$.

\footnotetext{
106 “A Justiça do Trabalho do século XXI, ao menos no contexto pátrio (e sobretudo após a EC 45/04), é fundamentalmente uma organização judiciária dedicada à defesa e à promoção de direitos fundamentais de cidadãos trabalhadores (especialmente os direitos de segunda geração ou dimensão, ditos 'direitos sociais')." (FELICIANO, Guilherme Guimarães (coord.). Fênix: por um novo processo do trabalho. São Paulo: LTr, 2011, p. 52).

107 “Ao direito processual que assegurará a efetividade das normas protetivas das garantias normativas trabalhistas impõe-se a impregnação das mesmas características" (FAVA, Marcos Neves. Ação civil pública trabalhista: teoria geral. 2 ed. São Paulo: LTr, 2008, p. 55). Cf. também PIRES, Líbia da Graça. Teoria da distribuição dinâmica do ônus da prova no processo do trabalho. Tese de Doutorado. São Paulo: Faculdade de Direito da Universidade de São Paulo, 2011, p. 222.

${ }^{108} \mathrm{O}$ direito do trabalho, "sob um prisma internacional, é, inegavelmente, uma face importante, e até mais visível, dos direitos humanos. [Logo], aquilo que muitas vezes encaramos como mero desrespeito de obrigações contratuais, quando estamos diante de um descumprimento de normas trabalhistas, trata-se, na verdade, de uma agressão aos direitos humanos" (SOUTO MAIOR, 2005, p. 214). Cf. também OLEA, 1997, p. 414-415; e CUNHA, Rodrigo Giostri da. O processo do trabalho como instrumento de efetivação dos direitos sociais trabalhistas: contribuições para o aprimoramento da prestação jurisdicional trabalhista. Dissertação de Mestrado. São Paulo: Faculdade de Direito da Universidade de São Paulo, 2008, p. 66.
} 
Da mesma forma, os processos que versam sobre alegações de assédio moral no âmbito de relação de emprego estão diretamente relacionados a direitos fundamentais e à própria dignidade da pessoa ${ }^{109}$. Não se pode, portanto, tratar esse tipo de processo com os mesmos parâmetros com que se tratam, por exemplo, ações de cobrança de débitos bancários, ou litígios entre pessoas jurídicas.

Os princípios informadores do processo do trabalho devem estar em sintonia com os princípios do direito do trabalho e, principalmente, com os parâmetros de sentido dos direitos fundamentais previstos na Constituição Federal ${ }^{110}$ (até mesmo por força da chamada eficácia irradiante dos direitos fundamentais, de que já se fez menção ${ }^{111}$ ). Com efeito, mostra-se incongruente haver no sistema jurídico, de um lado, um direito material informado por princípios como o da irrenunciabilidade e o da proteção do trabalhador, e de outro lado o direito processual com nítidas características liberais individualistas, informado por princípios como inércia da jurisdição e fomento à transação.

Nesse sentido, embora extrapole aos limites deste trabalho a construção de uma nova teoria geral do processo do trabalho, é preciso assentar algumas premissas necessárias ao desenvolvimento da linha de pesquisa, de modo a compatibilizar o processo do trabalho brasileiro com as promessas constitucionais relativas aos direitos fundamentais dos trabalhadores. A atuação do juiz do trabalho deve ser pautada, constantemente, pela ideia de realizar e implementar os direitos fundamentais ${ }^{112}$.

\footnotetext{
109 “A ocorrência do assédio moral no trabalho viola diversos direitos fundamentais do empregado, causandolhe prejuízos de ordem psíquica, fisiológica e econômica” (OLIVEIRA, P. E. V., 2013, p. 30).

110 “A proteção meramente paliativa destes direitos possui o efeito de esvaziar todo o sentido dos direitos previstos [...]" e "a efetividade processual desemboca na assunção de que cabe ao Estado o oferecimento de tutelas adequadas." (PONTINHA, Priscila Lopes. Ação inibitória no processo do trabalho e seus contornos processuais característicos. Revista Trabalhista Direito e Processo. São Paulo, ano 8, número 29, jan/mar 2009, p. 191). Cf. também CUNHA, 2008, p. 30.

${ }^{111}$ Vide tópico 3.2.2, supra.

112 "Natural, portanto, que tais características da relação jurídica de direito material que o processo do trabalho está voltado, as quais o direito comum desconhece, como regra, exerçam decisiva influência sobre as técnicas processuais e que, por isso mesmo, o processo transpareça pender para o lado do empregado." (SOUTO MAIOR, J. L.. Direito processual do trabalho: efetividade, acesso à justiça e procedimento oral. São Paulo: LTr, 1998, p. 23-24). Cf. também CUNHA, 2008, p. 40-41.
} 
Assim, em primeiro lugar, a inércia da jurisdição trabalhista (ne procedat udex ex officio) deve ser temperada pelo princípio da irrenunciabilidade dos direitos pelo trabalhador, e pela própria eficácia irradiante dos direitos fundamentais dos trabalhadores, na forma da Constituição Federal. Se o processo do trabalho é, como deve ser, o instrumento para a realização dos direitos fundamentais dos trabalhadores, a postura do juiz deve ser ativa e preocupada ${ }^{113}$ com a tutela de tais direitos, que escapam da esfera meramente individual do reclamante em causa própria. A integridade dos direitos trabalhistas é uma questão de manutenção de um modelo de sociedade baseado no sistema capitalista $^{114}$.

Nesse contexto, cabe ao juiz, por exemplo, a iniciativa de perquirir provas para constatar eventual descumprimento e inobservância de direitos pelo empregador, independentemente de aparente desinteresse (ou mesmo despreparo técnico) do autor da ação ou seu procurador. Ainda, no momento de decisão, deve-se admitir a chamada "extrapetição", no sentido da possibilidade de emissão de provimento jurisdicional distinto do postulado, ou em montante superior ao postulado, desde que observadas as garantias de contraditório e ampla defesa na fase de instrução do processo $^{115}$.

O princípio dispositivo sofre, portanto, uma restrição no processo do trabalho, decorrente dos princípios da proteção e da irrenunciabilidade.

113 "É preciso, portanto, que o juiz deixe de ser uma pessoa que apenas assiste à luta das partes em desigualdade de condições, inerte à espera do momento de decidir. O juiz tem que ser participativo. A ele foi incumbida a árdua tarefa de fazer justiça. Deverá por isso agir de forma a evitar as desigualdades" (BEBBER, Júlio César. Princípios do processo do trabalho. São Paulo: LTr, 1997, pp. 76-77).

114 Debruçando-se na análise dos efeitos da Primeira Guerra Mundial, SOUTO MAIOR refere que "no Tratado de Versalhes há um reconhecimento expresso de que o desprezo pelas condições de trabalho e de vida dos trabalhadores, advindas do modelo capitalista de produção, que se desenvolveu em nível mundial, foi uma das causas principais da conflagração." (2011, p. 251).

115 “A garantia do contraditório é inerente às partes litigantes” e, para observá-la, "é suficiente que seja dada oportunidade aos litigantes para se fazerem ouvir no processo" (NERY JUNIOR, 1996, p. 132-134); veja-se que essa afirmação não elide a possibilidade (e mesmo necessidade) de prestação ex officio da tutela jurisdicional. "Deve-se, pois, renunciar à adstrição do juiz ao pedido, liberando-o para conceder coisa diferente e/ou superior ao que fora pleiteado, diante da análise dos fatos e das provas presentes nos autos do processo." (BEBBER, J. C. Processo do trabalho: adaptação à contemporaneidade. São Paulo: LTr, 2011, p. 197). No mesmo sentido escreveu Marcos Neves FAVA: "Diversas são as consequências práticas, para o processo laboral, do reconhecimento de uma função - ou princípio - de intervenção social, do que é exemplo o enfraquecimento do poder dispositivo da parte, encerrado na instauração ex officio de dissídio coletivo, em caso de suspensão das atividades de trabalho, ou na concessão, aparentemente extra petita, de direitos garantidos na legislação, mas não explicitamente requeridos na exordial, v.g., a multa do art. 467 da CLT." (2008, p. 56). 
No processo comum vigora (também com alguns temperamentos, frise-se $\mathrm{e}^{116}$ ) o princípio dispositivo, pelo qual à parte cabe a iniciativa da postulação da tutela jurisdicional, e também a possibilidade de abrir mão dela ${ }^{117}$. Já no processo do trabalho, uma vez acionado o aparato judicial, os princípios informadores do direito material são também acionados, e passa a Justiça do Trabalho a deter interesse institucional na tutela dos direitos fundamentais envolvidos no caso concreto. É desse interesse que deve o juiz estar imbuído ao agir no processo que envolve direitos fundamentais do trabalhador.

Outra característica do processo do trabalho, segundo essa leitura constitucional, que é uma consequência do que se vem de sustentar, é a forte restrição ao princípio da autonomia da vontade.

A autonomia da vontade é um postulado do individualismo que marcou as bases do direito privado moderno. Segundo esse postulado, o sujeito pode dispor de seus direitos como melhor lhe aprouver, inclusive com a renúncia a seu exercício. A autonomia da vontade pressupõe uma igualdade formal entre os sujeitos envolvidos nas relações jurídicas, igualdade essa que na realidade se apresenta com foros de exceção à regra, de raridade. Justamente por isso, o próprio direito civil (cerne e matriz do direito privado) já admite muitas restrições ao princípio da autonomia da vontade.

No direito do trabalho, por sua vez, essa restrição deve ser muito mais forte. $\mathrm{O}$ trabalhador, por razões que dispensam explicações minuciosas, não tem condições fáticas de negociar com o empresário as cláusulas do contrato que regerá a relação de emprego. $\mathrm{Na}$ quase totalidade dos casos, o empresário fixa todas as cláusulas contratuais, e cabe ao

\footnotetext{
${ }^{116}$ BEDAQUE, José Roberto dos Santos. Poderes instrutórios do juiz. 3 ed. São Paulo: Editora Revista dos Tribunais, 2001, pp. 90-91.

117 “O princípio dispositivo consiste na regra de que o juiz depende, na instrução da causa, da iniciativa das partes quanto às provas e às alegações em que se fundamentará a decisão: iudex secundum allegata et probata partium iudicare debet. [...] Todavia, diante da colocação publicista do processo, não é mais possível manter o juiz como mero espectador da batalha judicial.” (CINTRA, Antônio Carlos de Araújo. DINAMARCO, Cândido Rangel. GRINOVER, Ada Pellegrini. Teoria geral do processo. 10 ed. São Paulo: Malheiros, 1994, p. 64, grifos do original).
} 
trabalhador apenas a decisão de aceitar, ou não, ingressar na empresa ${ }^{118}$. É um exemplo típico de contrato de adesão.

Ademais, após a formação do contrato de trabalho, também pode o empregador promover alterações baseadas naquilo que a doutrina concebe como o ius variandi, isto é, a prerrogativa de direcionar o modo da prestação de serviços no interesse da produção da empresa ${ }^{119}$.

Como se vê, é tal a desigualdade entre os sujeitos da relação de emprego que não se pode aceitar uma visão puramente contratualista, individualista, da situação desses mesmos sujeitos. O empregado precisa das normas jurídicas cogentes para obter a satisfação de seus direitos trabalhistas, pois não tem força para impor esse cumprimento ao empregador $^{120}$.

Daí por que o processo do trabalho não pode virar as costas a esses princípios do direito material. Processo do trabalho não é processo civil; é o instrumento por excelência de aplicação do direito do trabalho e deve ser influenciado pelos princípios do direito material. No processo, portanto, o trabalhador sofre, também, forte restrição em sua autonomia de vontade; assim é que não deve ser admitida, por exemplo, a renúncia pura e

\footnotetext{
${ }^{118} \mathrm{O}$ "empregador opta, enquanto opção nenhuma tem o trabalhador. Decide o capital, desde a existência do negócio, passando por sua estruturação, localização, ramo de atividade, tecnologia a ser impressa, até a forma de divulgação do produto ou serviço. Nada decide o trabalhador, senão a trabalhar ou não trabalhar. $\mathrm{O}$ salário, fixa-o a economia; a jornada, limita-a a lei; o turno, escolhe-o o patrão; as férias, designa-as o empregador; o sistema de folgas, escalona-o o contratante, etc." (FAVA, M. N. Execução trabalhista efetiva. São Paulo: LTr, 2009, p. 22).

${ }^{119}$ Paulo Emílio Ribeiro de VILHENA refere que "na grande maioria dos casos, o objeto da prestação do contrato de trabalho é indeterminado ou determinável. A determinabilidade incumbe ao empregador ou a quem o substitua na escala hierárquica ou no posto de comando de uma secção da atividade empresária". (Relação de emprego: estrutura legal e supostos, 3 ed. São Paulo: LTr, 2005, p. 261). "Se pode ditar a rotina diária do trabalho, o empregador também pode, naturalmente, mudar o tom e o teor de cada comando. É o ius variandi, o de certo modo, o poder diretivo em movimento." (VIANA, 1996, p. 214). Cf. também PLÁ RODRIGUEZ, 2000, p. 410-411; e SANTOS, Enoque Ribeiro dos. O dano moral na dispensa do empregado. 4 ed. São Paulo: LTr, 2009, p. 43.

120 Observa VIANA que "quem dá as ordens - quase sempre sozinho - é o empregador, não apenas determinando o modo pelo qual o empregado deve cumprir a prestação-trabalho, nem somente fiscalizando e aplicando punições, mas também regulando todos os outros aspectos da vida da empresa" (1996, p. 120).
} 
simples do direito postulado inicialmente ${ }^{121}$, a despeito de existir previsão desse ato no processo civil (CPC, art. 269, inciso V).

Tal conclusão tem especial validade para a análise da conciliação no processo do trabalho. Como se sabe, desde a década de 40 do século XX a Consolidação das Leis do Trabalho prevê o "espírito conciliatório" no processo do trabalho ${ }^{122}$. Na atualidade, esse espírito não apenas manteve sua vigência, como ainda se espraiou pelos demais ramos jurídicos, em grande parte como tentativa de resposta a problemas estruturais de funcionamento do Poder Judiciário no Brasil ${ }^{123}$.

Entretanto, não se pode perder de vista que a conciliação, no âmbito trabalhista, não pode ser usada como meio de obter verdadeira renúncia do trabalhador. $\mathrm{O}$ discurso de aplicação pura da regra de "concessões mútuas entre as partes", na forma como o legislador civil previu o instituto da transação (Código Civil, art. 840) tem dado azo, na rotina forense, a acordos absolutamente descabidos, com os quais, por um ou outro motivo, os trabalhadores consentem ${ }^{124}$.

${ }^{121}$ PLÁ RODRIGUEZ, ao se referir ao princípio da irrenunciabilidade, define sua aplicação como a "impossibilidade jurídica de privar-se voluntariamente de uma ou mais vantagens concedidas pelo direito trabalhista em benefício próprio" (2000, p. 142). Vê-se, pois, que a renúncia, pura e simples, no processo do trabalho, não se mostra compatível com o princípio basilar da irrenunciabilidade.

${ }^{122}$ É expresso o art. 764 da CLT sobre a sujeição de todos os processos da jurisdição da Justiça do Trabalho à conciliação. O caput do artigo dispõe que "os dissídios individuais ou coletivos submetidos à apreciação da Justiça do Trabalho serão sempre sujeitos à conciliação”. No que diz com a atuação dos juízes do Trabalho, o $\S 1^{\circ}$ do mesmo artigo estipula que eles "empregarão sempre os seus bons ofícios e persuasão no sentido de uma solução conciliatória dos conflitos".

Homero Batista Mateus da SILVA refere que "a afirmação do art. 764 no sentido de que os processos trabalhistas serão sempre sujeitos à conciliação foi desde cedo interpretada como sendo uma de suas características fundamentais, figurando, inclusive, nas listas de elementos de independência do processo do trabalho em relação ao processo civil." (Curso de direito do trabalho aplicado. v. 9. Rio de Janeiro: Elsevier, 2010, p. 10-11, grifo do autor).

${ }^{123}$ Nesse contexto foi editada pelo Conselho Nacional de Justiça (CNJ) a Resolução 125, de 29.11.2010, a qual "dispõe sobre a Política Judiciária Nacional de tratamento adequado dos conflitos", tendo em vista especialmente que "a conciliação e a mediação são instrumentos efetivos de pacificação social, solução e prevenção de litígios, e que a sua apropriada disciplina em programas já implementados nos país tem reduzido a excessiva judicialização dos conflitos de interesses, a quantidade de recursos e de execução de sentenças" (cf. exposição de motivos da Resolução 125/2010).

124 É nesse sentido a ressalva feita por CAPPELLETTI e GARTH (1988, p. 87): “Aqui, novamente, precisamos ser cuidadosos. A conciliação é extremamente útil para muitos tipos de demandas e partes, especialmente quando consideramos a importância de restaurar relacionamentos prolongados, em vez de simplesmente julgar as partes vencedoras ou vencidas. Mas, embora a conciliação se destine, principalmente, a reduzir o congestionamento do judiciário, devemos certificar-nos de que os resultados representam verdadeiros êxitos, não apenas remédios para problemas do judiciário, que poderiam ter outras soluções." 
Por exemplo, de fora parte os casos em que a pretensão processual do reclamante envolve matéria fática e provas orais ainda não apreciadas, muitas vezes a empresa reclamada comparece em audiência sem possuir a comprovação do pagamento das verbas rescisórias, das férias vencidas e não concedidas ao empregado, além dos depósitos do FGTS e eventual acréscimo rescisório de 40\%. Em tais situações, é possível a formalização de um acordo pelas partes, mas não se pode admiti-lo em valor inferior à somatória desses direitos mínimos. São direitos fundamentais do trabalhador, aos quais ele não pode renunciar ${ }^{125}$.

Não obstante, muitas vezes o trabalhador se vê premido por necessidades financeiras que o levam a aceitar um "acordo" em valor manifestamente inferior ao que é devido pela empregadora ${ }^{126}$. É nesse instante que o processo do trabalho, e o juiz do trabalho, concretamente, têm de atuar no sentido da restrição à autonomia da vontade do autor da ação, parte hipossuficiente na relação jurídica. A transação não pode importar em renúncia mascarada a direitos fundamentais, e o processo do trabalho não pode servir a interesses que tenham esse efeito (a renúncia) como norte ${ }^{127}$.

Não deve, contudo, o processo restringir a autonomia da vontade do trabalhador em transações lesivas e, de outro lado, deixá-lo à própria sorte, na espera do resultado de um procedimento que pode durar muito tempo ${ }^{128}$. Daí a importância da

${ }^{125}$ Dados empíricos significativos acerca do teor de acordos que têm sido homologados pela Justiça do Trabalho no Brasil encontram-se em HIRANO, Ana Farias. Acordos homologados pela Justiça do Trabalho: uma análise dos dissídios individuais na fase de conhecimento. Dissertação de Mestrado. Faculdade de Direito da Universidade de São Paulo, 2008.

${ }^{126}$ Esse fenômeno ocorre, inclusive e infelizmente, na fase de execução da sentença. "Rotineiros são, em sede do processo do trabalho, os acordos por valor inferior ao da liquidação, no curso das execuções, o que revela que o tempo está distribuído de forma não equânime, incentivando o abandono de direitos, para que o resultado efetivo - isto é, a entrega real do bem da vida disputado pelos litigantes - seja alcançado mediante renúncia de dada parcela dos valores em disputa, como franca demonstração do desespero do autor." (FAVA, 2009, p. 51).

127 "Por oportuno, registre-se que o princípio da conciliabilidade é também um princípio de conciliação responsável (o que revela outra vez a dialética com os princípios da razoabilidade e da proporcionalidade; ou, no plano jurídico-material, a dialética com o próprio princípio da irrenunciabilidade). Quer-se com isso dizer que o juiz do Trabalho pode, também por ele, recusar homologação a acordos ruinosos (i.e., espoliativos), fraudulentos (e.g., os simulatórios), genéricos (e.g., os desproporcionalmente quitatórios) ou ainda os tendentes a fins ilegais (e.g., aqueles instrumentalizados para a evasão fiscal)." (FELICIANO, 2011b, p. 37).

128 'É preciso ter muito claro, entretanto, que para a real proteção judicial dos direitos humanos não é suficiente e, pelo contrário, é perigoso só cumprir formalidades judiciárias, ter uma aparência de proteção 
aplicação de institutos como a tutela antecipada, regulado basicamente no art. 273 do Código de Processo Civil.

O processo do trabalho não tem regra expressa sobre a antecipação de tutela genérica, apenas previsões pontuais de liminares em casos de transferência de empregado e de reintegração de empregado estável por ser dirigente sindical ${ }^{129}$. Logo, a antecipação de tutela genérica, prevista no art. 273 do $\mathrm{CPC}^{130}$, é aplicável no processo do trabalho por força da regra do art. 769 da CLT. Quanto a essa aplicação, de fato, não há cizânia teórica relevante. A problemática na verdade é a aplicação efetiva, prática, do instituto da tutela antecipada no processo do trabalho.

A se assumirem as premissas relativas à missão constitucional do processo do trabalho, conforme se está a sustentar, a conclusão decorrente não pode ser outra: a tutela antecipada no processo do trabalho deve ser a regra, não a exceção.

E isso porque os requisitos previstos no art. 273 do CPC em geral estão presentes nas ações trabalhistas. Em primeiro lugar, o "fundado receio de dano irreparável

judicial, que adormece a vigilância e que não é, porém, mais do que uma ilusão de justiça." (DALLARI, Dalmo de Abreu. O poder dos juízes. 3 ed. São Paulo: Saraiva, 2007, p. 38).

${ }^{129}$ CLT, art. 659. Competem privativamente aos presidentes das Juntas, além das que lhe forem conferidas neste Título e das decorrentes de seu cargo, as seguintes atribuições:

$[\ldots]$

IX - conceder medida liminar, até decisão final do processo, em reclamações trabalhistas que visem a tornar sem efeito transferência disciplinada pelos parágrafos do artigo 469 desta Consolidação.

$\mathrm{X}$ - conceder medida liminar, até decisão final do processo, em reclamações trabalhistas que visem reintegrar no emprego dirigente sindical afastado, suspenso ou dispensado pelo empregador.

${ }^{130}$ Art. 273. O juiz poderá, a requerimento da parte, antecipar, total ou parcialmente, os efeitos da tutela pretendida no pedido inicial, desde que, existindo prova inequívoca, se convença da verossimilhança da alegação e:

I - haja fundado receio de dano irreparável ou de difícil reparação; ou

II - fique caracterizado o abuso de direito de defesa ou o manifesto propósito protelatório do réu.

$\S 1^{\circ} \mathrm{Na}$ decisão que antecipar a tutela, o juiz indicará, de modo claro e preciso, as razões do seu convencimento.

$\S 2^{\circ}$ Não se concederá a antecipação da tutela quando houver perigo de irreversibilidade do provimento antecipado.

$\S 3^{\circ}$ A efetivação da tutela antecipada observará, no que couber e conforme sua natureza, as normas previstas nos arts. 588, $461, \S \S 4^{\circ}$ e $5^{\circ}$, e $461-\mathrm{A}$.

$\S 4^{\circ}$ A tutela antecipada poderá ser revogada ou modificada a qualquer tempo, em decisão fundamentada.

$\S 5^{\circ}$ Concedida ou não a antecipação da tutela, prosseguirá o processo até final julgamento.

$\S 6^{\circ}$ A tutela antecipada também poderá ser concedida quando um ou mais dos pedidos cumulados, ou parcela deles, mostrar-se incontroverso.

$\S 7^{\circ}$ Se o autor, a título de antecipação de tutela, requerer providência de natureza cautelar, poderá o juiz, quando presentes os respectivos pressupostos, deferir a medida cautelar em caráter incidental do processo ajuizado. 
ou de difícil reparação" (inciso I) é intuitivo nas causas trabalhistas; com efeito, se o autor, na maioria das vezes desempregado, busca o recebimento de verbas salariais (consequentemente, de natureza alimentar) ou rescisórias, não há muito o que perquirir para constatar o preenchimento desse requisito legal. Afinal, muitas vezes será uma verdadeira busca pela sobrevivência. Da mesma forma, o "abuso de direito de defesa ou manifesto propósito protelatório do réu" (inciso II) pode ser facilmente aferido no caso concreto pelo juiz da causa.

Além disso, a concessão da tutela antecipada também pode ocorrer quando "um ou mais dos pedidos cumulados, ou parcela deles, mostrar-se incontroverso" (art. 273, $\left.\S 6^{\circ}\right)$. Não é raro que a ré, em sua defesa, admita o não pagamento de verbas rescisórias, por exemplo, sob o fundamento de dificuldades financeiras - e a situação concreta pode recomendar a antecipação da tutela de mérito, no todo ou em parte.

Por fim, cumpre mencionar o mais problemático dos requisitos da tutela antecipada: a "prova inequívoca" da "verossimilhança" da alegação do autor.

Independentemente das discussões gerais efetuadas pela doutrina do direito processual civil a respeito do exato alcance do requisito da verossimilhança, é preciso ler o caput do art. 273 do CPC com os mesmos olhos que leem o processo do trabalho a partir da Constituição Federal e dos direitos fundamentais. Ora, em se tratando de pleitos de pagamentos de parcelas rescisórias ou de verbas expressamente devidas ao empregado, o mínimo que se pode esperar do empregador que tenha razão é que demonstre a quitação dos títulos postulados de plano - demonstração essa que, a princípio, afastaria a verossimilhança da alegação do autor, de modo a repelir a antecipação da tutela.

De outro lado, em relação a pedidos da mesma natureza, caso a empresa ré não comprove, de plano, o pagamento das verbas postuladas, a verossimilhança da alegação do autor não existirá somente na hipótese de uma consistente argumentação de defesa, lastreada, evidentemente, em provas ou indícios razoáveis (alegação plausível de despedida por justa causa, por exemplo).

Caso contrário, isto é, ausente a prova do pagamento e também uma justificativa razoável e fundamentada, a antecipação da tutela de mérito é medida 
necessária. Retoma-se aqui a ideia de que a postura do juiz do trabalho deve ser a de quem tem a missão constitucional de proteger direitos fundamentais dos trabalhadores, com os instrumentos processuais colocados à sua disposição.

Não faz sentido uma situação em que a parte alega o descumprimento de direitos básicos, a outra parte não tem prova do cumprimento, tampouco justificativa para sua omissão, e caiba à parte lesada todo o ônus da espera pelo indefinido tempo de tramitação do processo. Ora, o instituto da tutela antecipada tem como função justamente distribuir de maneira mais adequada o ônus do tempo no processo, que não deve ser suportado exclusivamente pela parte que, aparentemente, tem razão ${ }^{131}$.

Esses os contornos que parecem indicar uma compreensão adequada do requisito da verossimilhança para a análise da tutela antecipada no processo do trabalho. Em verdade, o intérprete, ao apreciar a situação concreta, deve ter em mente a natureza do direito discutido e o risco que para a integridade desse mesmo direito representaria a demora no processo (o que nada mais é que a conjugação do caput do art. 273 com seu inciso I). Em se tratando de direitos trabalhistas básicos, ou mesmo de verbas rescisórias típicas, parece evidente que não se pode exigir muito para a constatação da verossimilhança da alegação.

Uma última característica que deve ser ressaltada no processo do trabalho contemporâneo, segundo sua leitura comprometida com os direitos fundamentais, é a prevalência da chamada tutela específica.

Nas obrigações de fazer e não fazer, o descumprimento da parte do devedor pode ensejar a conversão em equivalente monetário, para execução em tutela reparatória, ou então o direito pode ser protegido in natura, isto é, evitando-se a conversão em indenização de perdas e danos. Assim é a denominada tutela específica de obrigações de fazer e não fazer ${ }^{132}$, muito cara, aliás, aos propósitos desta pesquisa.

\footnotetext{
${ }^{131}$ MARINONI, L. G. Antecipação da tutela. 9 ed. São Paulo: RT, 2006, p. 23.

${ }^{132}$ Cf. arts. 461 e 461-A do Código de Processo Civil.
} 
Com efeito, em se tratando de direitos fundamentais dos trabalhadores, a tutela ressarcitória (conversão em indenização de perdas e danos) deve ser o último recurso do ordenamento para não deixar sem satisfação a lesão ocorrida. A primeira tentativa, sempre que possível, deve ser a proteção direta, a tutela específica. Em especial quando se cuida de direitos personalíssimos, como a integridade física e psíquica dos empregados, sua honra ou mesmo sua dignidade - bens jurídicos afetados pelo assédio moral, como se verá adiante.

Aliás, essa proposição nada mais é do que uma das facetas do direito fundamental de ação, garantido, pelo inciso XXXV do art. $5^{\circ}$ da Constituição Federal, em caso de lesão e também de ameaça a direito ${ }^{133}$.

Todavia, a práxis do processo do trabalho brasileiro não caminha, infelizmente, nessa direção. Sobre ela é a abordagem do próximo tópico.

\subsubsection{A visão patrimonialista e a necessidade de mudança}

A despeito das diretrizes constitucionais que deveriam reger o processo trabalhista, na esteira do quanto se expôs no tópico anterior, na prática forense o processo do trabalho atual se apresenta com forte feição patrimonialista ${ }^{134}$. Todas as discussões parecem resumir-se a quantias, a cálculos, a dívidas de valor. Discussões envolvendo horas extras, por exemplo, não raro são tratadas quase exclusivamente com fórmulas matemáticas (adicionais, divisores, reflexos etc), sem muitas alusões à importância histórica da limitação da jornada de trabalho e à influência que ela tem na manutenção da

\footnotetext{
${ }^{133}$ CUNHA, 2008, p. 37.

134 “Com efeito, a tradição celetária infelizmente legou ao Direito do Trabalho um viés contratualista [...] e sobretudo patrimonialista, encaminhando respostas monetárias - com inúmeros ensejos para multas, indenizações e reparações em pecúnia - onde a rigor caberiam tutelas preventivas ou reparações específicas [...]. Essa tendência recrudesceu-se no foro, ao longo de meio século, a tal ponto que as próprias soluções não monetizantes da Consolidação foram ofuscadas e praticamente não se veem na prática forense." (FELICIANO, Guilherme Guimarães. Tutela inibitória em matéria labor-ambiental. Revista do TST. Brasília, v. 77, número 4, out/dez 2011, p. 142).
} 
saúde dos trabalhadores. Desse modo, em alguns aspectos, o processo se desvincula da realidade material que tem o dever de regular $^{135}$.

Ações de cunho preventivo são raras. Poucas são as postulações de tutelas inibitórias ou específicas, justamente porque existe a cultura de olhar para o direito do trabalho como algo relacionado meramente a dívidas de valor, essencialmente negociáveis ${ }^{136}$.

Não é de se estranhar, portanto, que a conversão de obrigações específicas em perdas e danos seja a regra; a exceção é a proteção de direitos na forma do regime da tutela específica de obrigações de fazer e não fazer. Nesse sentido, assevera FELICIANO que

\begin{abstract}
Num ramo da Ciência Jurídica em que o objeto útil dos contratos é a própria força de trabalho da pessoa humana (i.e., uma projeção de sua personalidade), a vulnerabilidade dos direitos fundamentais de tantos quantos laborem sob subordinação é especialmente aguçada; e, no entanto, a imensa maioria das ações propostas na Justiça do Trabalho não persegue a satisfação dos conteúdos de direitos fundamentais como a vida, a integridade física, a liberdade, a honra, a privacidade ou a informação, mas a quitação de direitos de crédito de estrita aferição patrimonial. $^{137}$
\end{abstract}

E prossegue o autor:

Essa é, por evidente, uma disfunção do sistema brasileiro de tutela processual trabalhista. E o primeiro passo para corrigi-la é promover a

\footnotetext{
${ }^{135}$ Ademais, o "processo não é tratado como meio destinado a solucionar controvérsias, mas como fenômeno dotado de valores intrínsecos, na maioria das vezes representadas por formas vazias de conteúdo e desnecessárias à finalidade do ato processual. Daí decorre a valorização do meio em detrimento do fim inversão de valores que o processualista acaba aceitando, muitas vezes inconscientemente." (BEDAQUE, 2007, p. 53).

"O caráter patrimonial do direito do trabalho é apenas a forma tida como mais eficiente para a proteção de valores fundamentais, como a saúde, a vida e a dignidade do trabalhador.” (CUNHA, 2008, p. 71).

136 “A Consolidação das Leis do Trabalho, na mesma linha do antigo Código Civil, não se ocupou detidamente dos direitos de personalidade, com algumas poucas e raras exceções. [...] A lacuna, própria da época em que editada a CLT, decorre da visão reducionista do legislador, que tratou da relação de emprego como se nela as obrigações das partes se restringissem à prestação do trabalho pelo empregado, de um lado, e ao pagamento da remuneração pelo empregador, de outro lado. Tudo ficou limitado ao plano meramente patrimonial, o que se mostra tanto mais injustificável quanto é certo que, sendo o empregado, sempre e necessariamente, pessoa física (art. $3^{\circ}$, da CLT), os direitos de personalidade encontram-se inevitavelmente em causa em todo e qualquer contrato de trabalho." (MALLET, Estêvão. Direito, trabalho e processo em transformação. São Paulo: LTr, 2005, p. 18).
}

${ }^{137} 2005$, p. 2. 
conscientização difusa dos operadores jurídicos quanto às possibilidades e aos benefícios da tutela judicial preventiva e/ou restauradora nos quadros de violação (em ato ou potência) dos direitos fundamentais dos trabalhadores. ${ }^{138}$

É preciso mudar, portanto. E, na esteira do pensamento de FELICIANO, a mudança deve começar pela conscientização da função do processo em relação à proteção dos direitos fundamentais dos trabalhadores. Daí se poderá perceber com facilidade que a característica patrimonialista não contribui para essa função primordial do processo ${ }^{139}$.

O sistema real do processo do trabalho no Brasil é perverso. O discurso doutrinário e jurisprudencial da celeridade, simplicidade e eficácia já não tem tanta correspondência na prática ${ }^{140}$. O trabalhador, em regra, é dispensado de seu emprego e vai a juízo postular a tutela a direitos que alega terem sido desrespeitados. A audiência é agendada para período que, às vezes, encontra-se no limite do que se pode considerar razoável $^{141}$. Chegado o dia, não raro, por motivos diversos, a audiência é adiada. Após a audiência, também o julgamento pode demorar; depois os recursos, a citação para execução, impugnação aos cálculos e à penhora, novos recursos.

\footnotetext{
138 ibidem, p. 3.

139 “[...] as ações individuais, pelas quais se busca a reparação do dano sofrido, com a condenação do agressor ao pagamento daquilo que deveria ter pago, com a 'penalidade' dos juros de $1 \%$ ao mês, não capitalizados, mais correção monetária (contando sempre com a possibilidade do acordo, pelo qual se paga bem menos do que é devido) já se demonstraram completamente ineficazes para coagir ao cumprimento do direito do trabalho. O sistema processual, além disso, visto na perspectiva meramente ressarcitória e incentivando conciliações que, no fundo, representam autênticas renúncias aos direitos trabalhistas, acaba funcionando como incentivador da prática do ilícito [...]" (SOUTO MAIOR, 2005, p. 220).
}

${ }^{140}$ Em muitos aspectos, o processo civil comum avançou mais do que o processo do trabalho em relação à
efetividade da tutela jurisdicional; faz alguns anos que se veem as discussões sobre a aplicabilidade de vários
novos institutos do Código de Processo Civil (como o polêmico art. 475-J, entre outros) no âmbito do
processo do trabalho. "Não é demais destacar que o Processo do Trabalho tornou-se, ao longo do tempo,
emblema de simplicidade e eficiência, verdadeiro manancial de referência para a instituição do procedimento
dos juizados especiais cíveis, assim como para muitas das alterações aplicadas ao Código de Processo Civil.
Porém, isso não pode significar isolamento, tampouco reconhecimento de sua forma como perfeita ou imune
a atualizações e modernização. Pelo contrário, nossos dias são bem diferentes, as demandas no Poder
Judiciário também." (CHAVES, Luciano Athayde. A recente reforma no processo comum: reflexos no
direito judiciário do trabalho. 3 ed. São Paulo: LTr, 2007, p. 33-34).

${ }^{141}$ Nas grandes cidades do Brasil, não chega a causar espanto que uma audiência seja agendada para depois de um ano. 
A satisfação do direito pode demorar anos. Isso se essa perspectiva de demora do processo $^{142}$ não forçar, de certo modo, o autor da ação a aceitar um acordo em bases questionáveis para solucionar logo o litígio. Em certas situações práticas, esse ato final representa a desistência do cidadão de lutar pelo direito que a Constituição Federal lhe prometeu. É a vitória de quem infringiu a ordem jurídica, do devedor trabalhista.

Diante da premissa afirmada, e reafirmada, de que a missão do processo do trabalho é a de tutelar direitos fundamentais, esse cenário deve ser urgentemente alterado.

É preciso dar preferência à tutela preventiva dos direitos: evitar lesões a direitos do empregado, quando possível, deve ser prioridade na jurisdição trabalhista. Na atual conformação do processo civil, aliás, os operadores do processo do trabalho precisam construir alternativas para a proteção mais eficaz dos direitos em jogo ${ }^{143}$.

E não há razão para esperar reformas legislativas. A lentidão destas não se coaduna com os objetivos do processo do trabalho ${ }^{144}$. As lesões aos direitos ocorrem neste momento, a tutela prometida pela Constituição Federal é devida desde já, e o aparelhamento legal é suficiente para a respectiva prestação, uma vez interpretado criativamente, à luz dos princípios constitucionais ${ }^{145}$. Ademais, como salienta Júlio César

\footnotetext{
${ }^{142}$ Convencionou-se chamar de dano marginal o prejuízo causado pela demora na tramitação do processo, ainda que se trate exclusivamente do tempo minimamente necessário para a observância das garantias fundamentais das partes.

143 “O jurista contemporâneo não pode mais ser uma pessoa isolada do mundo e manietada intelectualmente, que se limita a reproduzir, sem qualquer reflexão, antigas ideias e práticas consagradas. Sua função social é muito maior. Cabe-lhe, por isso, situar-se o mais próximo possível da realidade, permitir a discussão axiológica, abandonar a pseudoneutralidade, e questionar a ordem estabelecida, a fim de dar ao direito um cunho progressista, com a criação de novas soluções.” (BEBBER, 2011, p. 72).
}

${ }^{144}$ É conveniente ressaltar que não há motivos para se temer a chamada judicialização da política, na medida em que inexistam abusos de poder por parte do Judiciário: "Diante desse movimento sociológico, certos autores têm empregado a expressão supra — 'judicialização da política’ — para designar a tendência pósmoderna de que as omissões ou insuficiências da legiferância e das políticas públicas sejam supridas pela construção jurisprudencial. Tendência que reputamos bem-vinda, se expurgados os excessos e as teratologias (pois, no limite, corroem o sistema dos 'checks and balances' e vulneram o princípio do artigo $2^{\circ}$ da CRFB). Esse fenômeno revela-se útil, se não necessário, para o pronto atendimento das novas demandas e a solução dos novos litígios, que do contrário defrontariam a inércia e a morosidade natural dos Poderes Executivo e Legislativo (a cujos trâmites políticos, próprios do 'iter' decisório, o Judiciário é menos permeável)." (FELICIANO, 2005, p. 29).

145 "No entanto, há que se considerar que apenas a elaboração de normas, prestigiando a deformalização, não é suficiente. No momento de interpretação e aplicação do direito, deve aquele que irá aplicá-lo ou interpretálo afastar-se de uma tendência que persegue os juristas em geral. Quer dizer, deve evitar uma interpretação que prestigie a formação de uma 'estrutura pesada e formal' e que frustre a efetivação dos interesses 
BEBBER, a reforma legislativa é importante, "mas não se pode pensar que todas as coisas mudam pela simples modificação legislativa. É preciso mais. É preciso reforma do pensamento. É preciso mudança de atitude."146

Daí a contribuição que este trabalho almeja fornecer. O objetivo é auxiliar na construção de possibilidades, de alternativas, na busca da prevenção do assédio moral na relação de emprego; aparelhar a jurisdição trabalhista com instrumentos aptos à tarefa de prevenir a consumação e as graves consequências do assédio moral. Para tanto, é preciso ter em mente que o processo do trabalho deve alcançar uma característica mais criativa e menos patrimonialista.

coletivos e difusos. Assim, embora esteja trabalhando com uma infra-estrutura 'leve e deformalizada' (a prevista na norma), o jurista pode, equivocadamente e através da interpretação, concretizar uma estrutura 'formalizada e pesada'. Este fato se deve, talvez, a uma deficiência na nossa cultura jurídica (que é transmitida, geração a geração, nas escolas), atada ao tradicional pensamento individualista herdado do direito civil liberal." (CORREIA, 1994, p. 29-30).

146 2011, p. 19. Ademais, conforme exposto por DALLARI (2007, p. 84), "[a] primeira grande reforma que deve ocorrer no Judiciário, e sem dúvida a mais importante de todas, é a mudança de mentalidade. [...] Ainda é comum ouvir-se um juiz afirmar, com orgulho vizinho da arrogância, que é 'escravo da lei'. E com isso fica em paz com sua consciência, como se tivesse atingido o cume da perfeição, e não assume responsabilidade pelas injustiças e pelos conflitos humanos e sociais que muitas vezes decorrem de suas decisões. [...] Um juiz não pode ser escravo de ninguém nem de nada, nem mesmo da lei". Até porque "o juiz escravo da lei tem grande possibilidade de ser, na realidade, escravo dos compradores de leis" (ibidem, p. 85). 


\title{
4. ASSÉDIO MORAL NA RELAÇÃO DE EMPREGO
}

\author{
Um homem se humilha \\ Se castram seu sonho \\ Seu sonho é sua vida, \\ E vida é trabalho. \\ E sem o seu trabalho, \\ Um homem não tem honra \\ E sem a sua honra, \\ Se morre, se mata \\ Não dá pra ser feliz, \\ Não dá pra ser feliz... ${ }^{147}$
}

\subsection{Considerações iniciais}

O fenômeno chamado no Brasil de assédio moral ${ }^{148}$ não é recente, nem próprio ou exclusivo das relações trabalhistas. Trata-se de uma manifestação de violência, e como tal certamente acompanha as relações humanas há muito tempo. É a violência psicológica $^{149}$, por meio da qual alguém submete uma pessoa a sofrimentos sem se expor diretamente à crítica de terceiros ou mesmo à reação da própria vítima, que não raro sequer consegue perceber de imediato que é alvejada por uma conduta hostil.

A atenção dispensada ao assédio moral em pesquisas acadêmicas é que tem aumentado. Justifica esse aumento o fato de que são relatados na imprensa e em processos judiciais comportamentos hostis entre alunos de uma escola, entre vizinhos, entre pessoas da mesma família. A área de abrangência das hostilidades psicológicas não é pequena.

\footnotetext{
${ }^{147}$ Gonzaguinha. "Um homem também chora (guerreiro menino)". In: Alô, Alô, Brasil. Rio de Janeiro: EMI, 1983.

148 "Conhecido na Europa como mobbing, no Brasil se utiliza o termo assédio moral”, espécie de violência que "sobreviveu por séculos inteiramente ignorada de médicos e juristas" (GUEDES, 2008, p. 19). A mesma autora informa que a "França adotou o termo harcèlement moral para definir o fenômeno e a Espanha o traduziu para acoso moral, vertendo-se para o português em assédio moral.” (ibidem, p. 33, grifos do original). Cf. também, sobre a nomenclatura equívoca do assédio moral, OLIVEIRA, P. E. V. (2013, p. 14).

149 TURTE, Samantha Lemos. Violência psicológica e assédio moral no trabalho: percepção e estratégias de enfrentamento de adolescentes trabalhadores. Dissertação de Mestrado. São Paulo: Faculdade de Saúde Pública da Universidade de São Paulo, 2011, p. 41 et seq.
} 
Mas a área trabalhista tem merecido destaque nos estudos sobre o assédio moral. A relação jurídica de emprego fornece um ambiente propício para essa prática: em sua própria configuração, como já se expôs, o poder é necessariamente unilateral ${ }^{150}$. Há de um lado o empregador, que dirige a atividade econômica na qual é empregada a força de trabalho alheia e, por essa mesma razão, detém o chamado poder diretivo ou empregatício $^{151}$. De outro lado, há o empregado, que presta mediante remuneração sua força de trabalho, subordinando-se ao poder do empregador.

É bem verdade que a doutrina ressalta o caráter meramente jurídico dessa subordinação do empregado ao empregador ${ }^{152}$, mas esse dado não deixa de ser interessante, pois realça a necessidade de constante vigilância sobre abusos do poder empregatício. É porque a tendência a ocorrerem esses abusos continua alta; o abuso do poder pelo empregador não sai da ordem do dia; chega a ser corriqueiro.

Não é apenas o aspecto jurídico da subordinação na relação de emprego que propicia o ambiente favorável à prática de hostilidades. Em geral, existe também uma forte dependência econômica do empregado, para quem o trabalho é fonte de subsistência, não raro a única, para si e sua família. A ameaça ou o perigo (real ou potencial) de perder o emprego podem ser vistos por ele como verdadeira ameaça à manutenção de sua vida. É uma situação de extrema gravidade. A tendência de submeter-se a desmandos do empregador ou do superior hierárquico provém do temor - às vezes verdadeiro pânico - de

\footnotetext{
${ }^{150}$ Daí a ênfase com que Paulo Eduardo Vieira de OLIVEIRA ressalta a importância da preservação da "cidadania sócio-laboral", isto é, a cidadania inserida no contexto da relação de emprego: "A matéria tem relevo jurídico inquestionável e eminente no campo do Direito do Trabalho por dois motivos: por um lado, pela especificidade da prestação do trabalho, cuja inseparabilidade da pessoa do trabalhador torna mais prováveis as ameaças aos seus direitos fundamentais; por outro lado, pela possibilidade de limitação desses mesmos direitos no quadro de vínculo de emprego, que necessita de enquadramento em termos jurídicos." (Direito do trabalho e cidadania. Revista LTr. v. 71. p. 1094-1098, 2007).

151 "Poder empregatício é o conjunto de prerrogativas asseguradas pela ordem jurídica e tendencialmente concentradas na figura do empregador, para exercício no contexto da relação de emprego. Pode ser conceituado, ainda, como o conjunto de prerrogativas com respeito à direção, regulamentação, fiscalização e disciplinamento da economia interna à empresa e correspondente prestação de serviços." (DELGADO, Maurício Godinho. Curso de direito do trabalho. 4 ed. São Paulo: LTr, 2005, p. 629).

152 OLIVEIRA, P. E. V. "Princípio da proteção da dignidade e da intimidade do trabalhador". In: NAHAS, Tereza Christina (Org.). Princípios de direito e processo do trabalho: questões atuais. Rio de Janeiro: Elsevier, 2009, p. 174. Para Otávio Pinto e SILVA, “a subordinação não é um status do trabalhador, pois não é ele o objeto do contrato de trabalho, mas sim sua atividade" (2004, p. 17). Cf. a respeito também SIMÓN, 2000, p. 108.
} 
perder o posto de trabalho; posto esse pelo qual o empregado pode pagar caro, com a própria saúde $^{153}$.

Esse o contexto no qual se insere a análise, já realizada ${ }^{154}$, de vinculação direta do empregador às normas consagradoras de direitos fundamentais de seus empregados. Trata-se da necessidade de proteger direitos fundamentais de pessoas que estão expostas ao poder alheio, numa relação desigual em que é extremamente reduzida a possibilidade de defesa.

Neste capítulo, propõe-se tomar contato com a doutrina mais específica do assédio moral trabalhista, de modo a estudar suas características e efeitos.

\subsection{Noção e espécies de assédio moral.}

\subsubsection{Dificuldades na formulação de uma definição de assédio moral}

Não é tarefa simples a proposição de uma definição de assédio moral, até porque não existe entre os estudiosos do tema um pleno consenso acerca das notas conceituais do fenômeno. Essa circunstância não traz, porém, nenhum prejuízo para a continuidade da pesquisa, na medida em que a definição estrita e exata de fenômenos como o assédio moral na relação de emprego é praticamente impossível. Existe o risco de um corte reducionista da realidade, no sentido de se evitar a nebulosidade significativa dos contornos da definição do assédio moral. Em outras palavras: ter a resposta pronta para cada hipótese (se é ou não é assédio moral) perde a importância em relação à análise da significação de cada caso, com seu contexto, causas e consequências ${ }^{155}$, sempre na perspectiva da efetividade da cláusula geral de tutela à pessoa ${ }^{156}$.

\footnotetext{
${ }^{153}$ Assim ocorre com “a permanente iminência do 'não-trabalho' ou do 'bico', que representa a ameaça da 'precariedade objetiva', que pode levar o trabalhador, e junto com ele sua família, a uma situação de perda de poder aquisitivo, muitas vezes de grandes proporções, causando ruptura em suas vidas, perda de identidade profissional e isolamento social." (SELIGMANN-SILVA, Edith et al. O mundo contemporâneo do trabalho e a saúde mental do trabalhador. Revista Brasileira de Saúde Ocupacional. São Paulo, volume 35, n. 122, julho-dezembro/2010, p. 187-188).

${ }^{154}$ Vide tópico 3.2.4, supra.

155 “Tal como não existe uma única designação, também não existe uma definição aceita por todos que estudam o fenômeno." (OLIVEIRA, P. E. V., 2013, p. 14).
} 
Desse modo, é importante apreender o conceito de assédio moral, conforme as definições doutrinárias mais aceitas. Entretanto, não há razão para prolongar a discussão sobre casos limítrofes; uma análise jurídica do assédio moral na relação de emprego deve ter como norte, sempre, o estado de sujeição da vítima e a potencial violação a seus direitos fundamentais, em um contexto de construção de um meio ambiente do trabalho sadio e equilibrado $^{157}$. Se todos, ou somente alguns autores concordam que tal ou qual conduta seria definida como assédio moral, é um aspecto não muito profícuo da discussão, para os objetivos do presente trabalho ${ }^{158}$.

\subsubsection{Definições doutrinárias e legislativas. Conceito proposto.}

A proposta deste tópico é a apresentação de um panorama das definições mais correntes do assédio moral na relação de trabalho.

Para a autora francesa Marie-France HIRIGOYEN, importante referência nos estudos relacionados ao assédio moral, este

é definido como qualquer conduta abusiva (gesto, palavra, comportamento, atitude...) que atente, por sua repetição ou sistematização, contra a dignidade ou integridade psíquica ou física de

\footnotetext{
156 "A tutela da pessoa humana não pode ser fracionada em isoladas hipóteses, microssistemas, em autônomas fattispecie não-intercomunicáveis entre si, mas deve ser apresentada como um problema unitário, dado o seu fundamento, representado pela unidade do valor da pessoa. Esse fundamento não pode ser dividido em tantos interesses, em tantos bens, como é feito nas teorias atomísticas. A personalidade é, portanto, não um 'direito', mas um valor, o valor fundamental do ordenamento, que está na base de uma série (aberta) de situações existenciais, nas quais se traduz a sua incessantemente mutável exigência de tutela. Por isso, não pode existir um número fechado (numerus clausus) de hipóteses tuteladas: tutelado é o valor da pessoa, sem limites, salvo aqueles postos no seu interesse e no interesse de outras pessoas humanas. Nenhuma previsão especial pode ser exaustiva, porque deixaria de fora, necessariamente, novas manifestações e exigências da pessoa, que, com o progredir da sociedade, passam a exigir uma consideração positiva." (MORAES, Maria Celina Bodin de. Danos à pessoa humana: uma leitura civil-constitucional dos danos morais. Rio de Janeiro: Renovar, 2003, p. 121, grifos do original).

${ }^{157}$ TURTE, 2011, p. 48.

${ }^{158}$ Salienta-se, apenas para maior clareza: não é irrelevante ou indevida a discussão doutrinária acerca dos exatos limites da definição de assédio moral. O que se vem de sustentar é que, para o objetivo do presente trabalho, essa discussão não gera consequências relevantes, pois é possível uma interpretação "extensiva" do conceito de assédio moral, por assim dizer.
} 
uma pessoa, ameaçando seu emprego ou degradando o clima de trabalho. ${ }^{159}$

Trata-se, como se vê, de um conceito bastante amplo, o que não significa necessariamente uma deficiência. Em verdade, a noção de assédio moral não diz tanto com condutas plenamente identificadas ou identificáveis, quanto com um processo de agressão psicológica, que deve ser analisado em seu todo. A mesma autora realça que "cada ataque tomado de forma isolada não é verdadeiramente grave; o efeito cumulativo dos microtraumatismos frequentes e repetidos é que constitui a agressão"160.

Essa é, aliás, uma das facetas mais cruéis do assédio moral. A conduta hostil é de início quase imperceptível, de modo que a vítima demora a perceber que está sendo $\operatorname{agredida}^{161}$.

A tônica do conceito de assédio moral, proposto por HIRIGOYEN, incide, portanto, nas ideias de "repetição ou sistematização".

Márcia Novaes GUEDES, na mesma linha de entendimento, afirma que

No mundo do trabalho, assédio moral significa todos aqueles atos comissivos ou omissivos, atitudes, gestos e comportamentos do patrão, da direção da empresa, de gerente, chefe, superior hierárquico ou dos colegas, que traduzem uma atitude de contínua e ostensiva perseguição que possa acarretar danos relevantes às condições físicas, psíquicas, morais e existenciais da vítima. ${ }^{162}$

\footnotetext{
${ }^{159}$ HIRIGOYEN, Marie-France. Mal-estar no trabalho: redefinindo o assédio moral. Tradução de Rejane Janowitzer. 4 ed. Rio de Janeiro: Bertrand Brasil, 2009, p. 17.

${ }^{160}$ Ibidem, p. 17.

161 "Por meio de palavras aparentemente inofensivas, alusões, sugestões ou não-ditos, é efetivamente possível desequilibrar uma pessoa, ou até destruí-la, sem que os que a rodeiam intervenham." (HIRIGOYEN, M-F. Assédio moral: a violência perversa no cotidiano. Tradução de Maria Helena Kühner. 11 ed. Rio de Janeiro: Bertrand Brasil, 2009, p. 11). "As vítimas procuram levar na brincadeira ou ignorar em um primeiro momento. Só que as agressões se multiplicam, não param. O indivíduo é acuado, atacado, inferiorizado por um longo e tormentoso período. Surgem os impactos psicológicos mais comuns: humilhação, depressão, cansaço intermitente, perda do sono, crise nervosa, choro." (CERQUEIRA, Vinícius da Silva. Assédio moral organizacional nos bancos. Dissertação de Mestrado. Faculdade de Direito da Universidade de São Paulo, 2012, p. 20).
}

162 2008, p. 33. 
Reforça a autora a ideia de continuidade para a configuração do assédio moral, mantendo a amplitude das condutas que podem ser usadas para a prática da agressão psicológica. Em outras palavras, o assédio é um processo complexo tendente a afrontar a integridade pessoal da vítima.

Já segundo Sônia Mascaro NASCIMENTO, o assédio moral

caracteriza-se por ser uma conduta abusiva, de natureza psicológica, que atenta contra a dignidade psíquica, de forma repetitiva e prolongada, e que expõe o trabalhador a situações humilhantes e constrangedoras, capazes de causar ofensa à personalidade, à dignidade ou à integridade psíquica, e que tenha por efeito excluir a posição do empregado no emprego ou deteriorar o ambiente de trabalho, durante a jornada de trabalho e no exercício de suas funções. ${ }^{163}$

Trata-se de outra definição que, não obstante a tentativa de maior delimitação conceitual em relação às anteriores, se apresenta bastante ampla, e também menciona o caráter procedimental do assédio moral (“de forma repetitiva e prolongada”).

Paulo Eduardo Vieira de OLIVEIRA entende que

o assédio moral no trabalho é uma forma de comportamento negativa entre trabalhadores, ou entre superiores hierárquicos e subordinados, pelo qual a pessoa ou as pessoas visadas são repetidamente humilhadas, direta ou indiretamente, por uma ou mais pessoas, com o propósito de isolamento. ${ }^{164}$

Candy Florêncio THOME também assevera que a repetição dos atos de agressão psicológica é essencial para a identificação do assédio moral ${ }^{165}$. No mesmo sentido, e com amparo em autores espanhóis, Zeno SIMM entende que a reiteração de conduta integra a definição do assédio moral ${ }^{166}$. Por fim, Sebastião Geraldo de OLIVEIRA menciona expressamente a reiteração como elemento de sua definição de assédio moral ${ }^{167}$.

163 NASCIMENTO, Sônia A. C. Mascaro. O assédio moral no ambiente do trabalho. Jus Navigandi, Teresina, ano 8, n. 371, 13 jul. 2004. Disponível em: 〈http://jus2.uol.com.br/doutrina/texto.asp?id=5433〉. Acesso em: 16 out. 2010.

1642013 , p. 25.

165 THOME, Candy Florêncio. O assédio moral nas relações de emprego. 2 ed. São Paulo: LTr, 2009, p. 40.

${ }^{166}$ Para o autor, que se refere ao fenômeno como "acosso psíquico", "parece mais correto concluir-se que a prática reiterada do comportamento lesivo é mesmo elemento identificador do acosso psíquico, presente em 
Para além das definições doutrinárias, também se verificam no Brasil, em âmbitos municipais e estaduais, algumas definições de assédio moral ${ }^{168}$. A Lei 13.288/2002, do Município de São Paulo, dispõe sobre a aplicação de penalidades aos servidores públicos pela prática do assédio moral e, no parágrafo único do art. $1^{\circ}$, define o assédio moral como

todo tipo de ação, gesto ou palavra que atinja, pela repetição, a autoestima e a segurança de um indivíduo, fazendo-o duvidar de si e de sua competência, implicando em dano ao ambiente de trabalho, à evolução da carreira profissional ou à estabilidade do vínculo empregatício do funcionário, tais como: marcar tarefas com prazos impossíveis; passar alguém de uma área de responsabilidade para funções triviais; tomar crédito de idéias de outros; ignorar ou excluir um funcionário só se dirigindo a ele através de terceiros; sonegar informações de forma insistente; espalhar rumores maliciosos; criticar com persistência; subestimar esforços.

A definição legal, além de salientar a repetição dos atos ofensivos, traz um rol exemplificativo de condutas que se enquadram no conceito de assédio moral adotado. $\mathrm{Na}$ mesma esteira, outros Municípios brasileiros também regulamentaram punições por assédio moral no âmbito de suas administrações, mencionando definições semelhantes à

sua definição, e quando o dano psíquico emergir de um único ato isolado poder-se-á estar diante de uma figura distinta, igualmente censurável" (SIMM, Zeno. Acosso psíquico no ambiente de trabalho. São Paulo: LTr, 2008, p. 112).

167 "Considera-se, portanto, assédio moral o comportamento do empregador, seus prepostos ou colegas de trabalho, que exponha o empregado a reiteradas situações constrangedoras, humilhantes ou abusivas, fora dos limites normais do poder diretivo, causando degradação do ambiente laboral, aviltamento à dignidade da pessoa humana ou adoecimento de natureza ocupacional.” (OLIVEIRA, S. G., 2011, p. 235).

Na mesma linha de entendimento estão Maria Aparecida ALKIMIN (2009, p. 38 e p. 43), Viviany GALVÃO (Assédio moral: mal-estar no trabalho. Maceió: Edufal, 2011, p. 86), Vilja Marques ASSE (Um fenômeno chamado psicoterrorismo. Revista LTr, São Paulo, v. 68, n. 7, julho/2004, p. 819), José Affonso DALLEGRAVE NETO (Responsabilidade civil no direito do trabalho. 3 ed. São Paulo: LTr, 2008, p. 210), Mauro SCHIAVI (Ações de reparação por danos morais decorrentes da relação de trabalho. São Paulo: LTr, 2007, p. 117), Alice Monteiro de BARROS (Proteção à intimidade do empregado. São Paulo: LTr, 1997, p. 184), Ernesto LIPPMANN (Assédio sexual nas relações de trabalho. 2 ed. São Paulo, LTr, 2004, p. 36), Claudio Armando Couce de MENEZES (Assédio moral e seus efeitos jurídicos. Jus Navigandi. Teresina, ano 14, n. 2489, 25.4.2010. Disponível em http://jus2.uol.com.br/doutrina/texto.asp?id=14747. Acesso em 16.10.2010, p. 2), CERQUEIRA (2012, pp. 21-22).

${ }^{168}$ Existe uma longa relação de leis e projetos de lei que versam sobre assédio moral disponível para consulta em www.assediomoral.org. 
adotada pela Lei do Município de São Paulo ${ }^{169}$, com variações não essenciais do ponto de vista do conceito.

No âmbito estadual, a primeira Lei aprovada no Brasil sobre o tema, ao que se pôde apurar, foi a Lei 3.921/2002, do Estado do Rio de Janeiro, cujo art. $2^{\text {o }}$ dispõe:

\begin{abstract}
Artigo $2^{\circ}$ - Considera-se assédio moral no trabalho, para os fins do que trata a presente Lei, a exposição do funcionário, servidor ou empregado a situação humilhante ou constrangedora, ou qualquer ação, ou palavra ou gesto, praticada de modo repetitivo e prolongado, durante o expediente do órgão ou entidade, e, por agente, delegado, chefe ou supervisor hierárquico ou qualquer representante que, no exercício de suas funções, abusando da autoridade que lhe foi conferida, tenha por objetivo ou efeito atingir a auto-estima e a autodeterminação do subordinado, com danos ao ambiente de trabalho, aos serviços prestados ao público e ao próprio usuário, bem como, obstaculizar a evolução da carreira ou a estabilidade funcional do servidor constrangido.
\end{abstract}

Parágrafo único - $\mathrm{O}$ assédio moral no trabalho, no âmbito da administração pública estadual e das entidades colaboradoras, caracteriza-se, também, nas relações funcionais escalões hierárquicos, pelas seguintes circunstâncias:

I. determinar o cumprimento de atribuições estranhas ou atividades incompatíveis com o cargo do servidor ou em condições e prazos inexeqüíveis;

II. designar para funções triviais, o exercente de funções técnicas, especializadas ou aquelas para as quais, de qualquer forma, sejam exigidos treinamento e conhecimento específicos;

III. apropriar-se do crédito de idéias, propostas, projetos ou de qualquer trabalho de outrem;

IV. torturar psicologicamente, desprezar, ignorar ou humilhar o servidor, isolando-o de contatos com seus colegas e superiores hierárquicos ou com outras pessoas com as quais se relacione funcionalmente;

V. sonegar de informações que sejam necessários ao desempenho das funções ou úteis à vida funcional do servidor;

VI. divulgar rumores e comentários maliciosos, bem como críticas reiteradas, ou subestimar esforços, que atinjam a saúde mental do servidor; e

VII. na exposição do servidor ou do funcionário a efeitos físicos ou mentais adversos, em prejuízo de seu desenvolvimento pessoal e profissional.

${ }^{169}$ Alguns desses diplomas são os seguintes: Lei 4.027/2003, de Bagé-RS; Lei 3.671/2002, de Americana-SP; Lei 2.665/2006, de Balneário Camboriú-SC; Lei 2.949/2002, de Brasília-DF; Lei 11.409/2002, de CampinasSP; Lei 5.534/2002, de Divinópolis-MG; Lei 1.977/2003, de Gravataí-RS; Lei 358/2002, de Guarulhos-SP; Lei 189/2002, de Natal-RN; Lei 2.382/2003, de Resende-RJ; Lei 1.510/2007, de Rolim de Moura-RO; Lei 6.986/2006, de Salvador-BA; Lei 511/2003, de São Gabriel d'Oeste-MS; Lei 1.210/2004, de Sorriso-MT. 
Mais uma ratificação do caráter sistemático do assédio moral, uma vez que a Lei refere expressamente o "modo repetitivo e prolongado" das práticas ofensivas. São semelhantes, nesse aspecto, as legislações dos Estados de Minas Gerais ${ }^{170}$ e São Paulo ${ }^{171}$. Além disso, também o Estado de Mato Grosso possui legislação que veda a prática de assédio moral e sexual, mas não traz definição das respectivas condutas ${ }^{172}$; ainda, a legislação do Estado do Rio Grande do Sul proíbe a prática do assédio moral, mas os artigos que traziam definições foram vetados pelo Governador do Estado ${ }^{173}$. Remanesce na legislação, por assim dizer, uma vedação com cláusula aberta.

Em âmbito federal, pouco existe de regulamentação normativa acerca do assédio moral. Pode-se pôr em relevo, contudo, nesse cenário de predominante silêncio, que a Lei 11.948/2009 veda a concessão de crédito pelo Banco Nacional de Desenvolvimento Econômico e Social (BNDES) a empresas condenadas por assédio moral. $\mathrm{O}$ art. $4^{\circ}$ da Lei dispõe:

Art. $4^{\circ}$ - Fica vedada a concessão ou renovação de quaisquer empréstimos ou financiamentos pelo BNDES a empresas da iniciativa privada cujos dirigentes sejam condenados por assédio moral ou sexual, racismo, trabalho infantil, trabalho escravo ou crime contra o meio ambiente.

Conquanto não tenha o legislador trazido nenhuma definição de assédio moral (o que não seria mesmo recomendável, dada a finalidade orçamentária do diploma legal em exame), a medida restritiva funda-se no entendimento do Poder Judiciário sobre o tema. A vedação deriva de condenação (não há exigência de trânsito em julgado) por prática de assédio moral, entre outras figuras cuja gravidade evidente indica que o assédio está a demandar mais atenção da sociedade e do poder público. Passa da hora, portanto, da edição de uma legislação federal específica sobre o assédio moral nas relações de trabalho.

À vista de todos os elementos referidos, é possível compreender o assédio moral trabalhista como um processo de agressão psicológica, instaurado no meio ambiente

\footnotetext{
${ }^{170}$ Lei Complementar 117/2011, do Estado de Minas Gerais.

${ }^{171}$ Lei 12.250/2006, do Estado de São Paulo.

${ }^{172}$ Lei Complementar 4/1990, do Estado de Mato Grosso, art. 144, inciso XIX (redação dada por lei de 2009).

${ }^{173}$ Lei 12.561/2006, do Estado do Rio Grande do Sul.
} 
do trabalho, composto de um conjunto sistemático de atos, comissivos ou omissivos, praticados de forma reiterada e capazes de minar a autoconfiança da vítima, desestabilizála psicologicamente e subjugá-la aos interesses do agressor.

Alguns aspectos do conceito proposto devem ser salientados. Em primeiro lugar, é necessário compreender o assédio moral como um processo ${ }^{174}$, composto por vários atos, reiteradamente praticados. Como se viu, a doutrina é sedimentada no sentido de que a reiteração é necessária à configuração do assédio ${ }^{175}$. Não é, portanto, assédio moral a conduta única e delimitada do patrão ou de superior hierárquico ou de colega de trabalho que ofenda a vítima diretamente em sua personalidade, intimidade ou honra. Temse nesse caso uma conduta não abrangida no conceito de assédio moral - o que não significa, evidentemente, a exclusão de seu caráter ilícito.

Em segundo lugar, os efeitos do assédio moral não devem compor a sua definição, pois lhe são externos. Daí a preferência pela locução capazes de na definição acima exposta. $\mathrm{O}$ agir do assediador tem a capacidade de gerar os nefastos efeitos conhecidos do assédio moral, e é o que basta; se, de fato, tais danos foram causados em concreto, é uma questão alheia à conceituação da conduta do agressor como assédio moral $^{176}$. Justifica-se essa opção, inclusive, porque são diferentes os níveis de resistência das pessoas a agressões psicológicas ${ }^{177}$. Alguns indivíduos podem sucumbir às primeiras investidas de um chefe perverso; a outros, em razão de características pessoais, podem as

\footnotetext{
${ }^{174}$ Entende-se por processo uma "sequência contínua de fatos ou operações que apresentam certa unidade ou que se reproduzem com certa regularidade" (Grande Dicionário Houaiss da Língua Portuguesa, versão eletrônica, disponível em < http://houaiss.uol.com.br $>$ ).

${ }^{175}$ É expressa a doutrina de Paulo Eduardo Vieira de OLIVEIRA no sentido de que "deve ser acrescentado um outro importante elemento para identificação do assédio moral no trabalho, qual seja, o caráter repetitivo e sistemático da conduta do agressor" (2013, p. 31), uma vez que o "assédio moral não se manifesta em uma única ocorrência, sendo necessária a prática repetida e reiterada de atos que, mesmo sendo isoladamente de pouca gravidade, dada a repetição, podem levar a situações muito graves." (ibidem, p. 43-44).

${ }^{176}$ A conclusão que se vem de sustentar tem amparo na doutrina de Paulo Eduardo Vieira de OLIVEIRA: "O resultado final, que não é necessariamente propositado, é o isolamento no ambiente de trabalho ou a saída do local de trabalho, ou mesmo a rescisão do contrato de trabalho a pedido do empregado." (2013, p. 25, grifo nosso).

177 "Pero, aunque haya alguna divergencia doctrinal, los daños psicológicos de la víctima, siendo un indicio muy significativo de la existencia de acoso moral, no son una exigencia constitutiva de la existencia de acoso moral. Si le diéramos ese valor, "podría comportar hacer de peor condición a aquellas personas con mayor resistência'." (LOUSADA AROCHENA, José Fernando. La prueba de la discriminación y del acoso sexual y moral em el proceso laboral. Cadernos da Amatra IV. Porto alegre, ano 2, n. 3, abril-junho/2002. Disponível em <http://www.amatra4.org.br/publicacoes/cadernos/caderno-03?start=4〉, acesso em 24.10.2011, p. 15).
} 
mesmas investidas revelar-se inofensivas do ponto de vista do dano psicológico ou moral. Mas numa e noutra hipótese a avaliação dos atos do chefe deve chegar à mesma conclusão: será, ou não, assédio moral.

Em terceiro lugar, o conceito proposto não especifica quais são os interesses que movem o assediador. Opta-se, com isso, por não restringir a qualificação do assédio moral em função da real intenção do agressor. Tais interesses podem consistir em eliminar a vítima da empresa, destruí-la psicologicamente ou mesmo fazê-la trabalhar mais e mais, no intuito de incrementar a produtividade. Pode haver, também, outro interesse não identificável, diferente dos mais conhecidos ou recorrentes. Mas esses aspectos não devem ter relevância para qualificar-se, ou não, a conduta agressiva como assédio moral.

Encerra este tópico a ressalva de que o conceito de assédio moral é necessariamente amplo, e está em constante construção. O fenômeno é complexo e dinâmico, e a cada dia pode ser constatado em práticas diferentes, em variados lugares e empresas. Não parece viável, portanto, fechar os contornos de uma definição estrita do que seja assédio moral na relação de emprego, para repelir o enquadramento no conceito de condutas que se mostrem essencialmente similares. A análise do caso concreto à luz das características do assédio moral indicará o correto enquadramento teórico da questão.

\subsubsection{Espécies de assédio moral}

As espécies de assédio moral na relação de emprego, mais frequentemente mencionadas na doutrina, são as decorrentes de uma classificação com base na direção e sentido do fluxo de violência psicológica. Assim, haveria o assédio moral vertical (descendente e ascendente) e o horizontal. De cada uma dessas espécies se tratará nos tópicos seguintes.

Além dessas, porém, uma outra categoria tem exigido mais atenção, a do assédio moral organizacional, cuja abordagem será também efetuada em tópico específico. Aliás, opta-se por iniciar a exposição justamente pelo assédio organizacional, já que sua compreensão se afigura imprescindível para a correta visão das demais espécies mencionadas. 
De fato, qualquer tipo de assédio moral trabalhista (horizontal, vertical descendente ou vertical ascendente) deve ser estudado pela ótica da organização, isto é, da empresa ou estabelecimento empregador. Por outras palavras, o estudo parte do ponto de vista da organização, cujo arranjo influencia as relações pessoais entre os trabalhadores, como se verá a seguir.

\subsubsection{Assédio moral organizacional}

O assédio moral organizacional "é um processo contínuo de hostilidades, estruturado via política organizacional ou gerencial, que tem como objetivo imediato aumentar a produtividade, diminuir custos, reforçar os espaços de controle, ou excluir os trabalhadores que a empresa não deseja manter em seus quadros." 178

Aqui, note-se, a figura do agressor é em verdade exercida pela empresa, pela organização. A organização quer fazer valer seus interesses por meio da violência, que é institucionalizada (embora nunca assumida, sempre pressuposta) nas relações pessoais entre os empregados, em especial no sentido da direção do fluxo de poder hierárquico (de cima para baixo - vertical descendente).

O assédio organizacional não depende da presença de um indivíduo perverso em posto de comando; não tem natureza subjetiva. Na verdade, é a organização que atua de modo perverso, e as pessoas que ali trabalham são levadas a atos com os quais não necessariamente concordariam ${ }^{179}$.

\footnotetext{
${ }^{178}$ SOBOLL, Lis Andrea P.; GOSDAL, Thereza Cristina (organizadoras). Assédio moral interpessoal e organizacional: um enfoque interdisciplinar. São Paulo: LTr, 2009, p. 19.

179 “O assédio organizacional independe da intenção deliberada do agente de degradar as condições de trabalho ou atingir o empregado, mas representa uma escolha da empresa ou instituição como estratégia de administração, de redução de custos e/ou, de estimular maior produtividade" (SOBOLL e GOSDAL, 2009, p. 38).
} 
Essa modalidade de assédio moral não passou despercebida a HIRIGOYEN, não obstante o enfoque subjetivo característico de suas análises, voltadas em geral às personalidades dos agressores e das vítimas ${ }^{180}$. Ela relata que

Se a perversidade consiste em levar os indivíduos na direção do que existe de pior neles e incutir comportamentos perversos, pode-se dizer que incontestavelmente existem empresas perversas. Em lugar de incentivar cada empregado a dar o melhor de si mesmo, no seu próprio interesse e no da empresa, elas acirram as rivalidades e fazem com que as pessoas utilizem procedimentos desleais. ${ }^{181}$

E ainda:

Quando a hierarquia impõe a um grupo de trabalhadores objetivos dificilmente alcançáveis, pode ocorrer a tentação de excluir do grupo os menos produtivos. Quando uma direção deseja livrar-se de um empregado, contenta-se por vezes em sugerir ao grupo que ele é indesejável. Os colegas, por espírito de obediência ou por medo, afastamse dele, isolam-no e, por um processo agora bem conhecido, assediamno. ${ }^{182}$

Como se vê, há uma faceta do assédio moral que independe das personalidades dos sujeitos envolvidos diretamente nas condutas hostis ${ }^{183}$. Esse é o assédio organizacional.

Nessa modalidade de assédio moral, é relevante a influência do próprio modelo de produção atual ${ }^{184}{ }^{185}$. Com efeito, é comum em várias empresas, de distintos ramos de atuação, a divisão dos empregados em equipes, que competem entre si por

\footnotetext{
${ }^{180}$ Características percebidas também na crítica de CERQUEIRA (2012, p. 30-31).

${ }^{181}$ HIRIGOYEN, 2009b, p. 208.

${ }^{182}$ ibidem, p. 272.

183 “Os executivos que transmitem a perversidade não sentem prazer em fazer sofrer; às vezes até sofrem de verdade por causar sofrimento; porém, por medo ou covardia, calam-se. É como se [...] seu senso moral não existisse ou lhes tivesse sido extirpado [...]." (HIRIGOYEN, ibidem, p. 274).

${ }^{184}$ ALKIMIN, 2009, p. 70; ASSE, 2004, p. 820.

185 "Esse modelo fragmentado e individualizado de produção propicia a desarticulação da organização de classe dos trabalhadores, que acusa uma retração acentuada a partir do final da década de 80. [...] Soma-se a esse quadro hostil, a adesão por algumas empresas à violência psicológica ou violência invisível para o controle da subjetividade dos trabalhadores." (ARAÚJO, Adriane Reis. O assédio moral organizacional e medidas internas preventivas e repressivas. In: SOBOLL e GOSDAL, 2009, p. 57).
} 
produção com a finalidade de receber "prêmios" em forma de remuneração adicional. Práticas de gestão como essa não colaboram para o sentimento de solidariedade entre os trabalhadores, que passam a se ver como adversários uns dos outros ${ }^{186}$.

Aliás, o efeito é exatamente o oposto da solidariedade: é a acentuação do individualismo, o qual inegavelmente favorece o assédio moral ${ }^{187}$. A tônica da presente abordagem é, portanto, desvelar a atuação da organização: esta não é "neutra" ou "inocente" na maioria dos episódios de assédio moral entre seus empregados. A dinâmica das relações pessoais na empresa é ditada pela organização; esta compõe um arranjo produtivo que propicia as condutas de assédio entre os empregados.

O referido arranjo produtivo não é elaborado sem finalidades muito bem definidas. No exemplo da divisão de trabalhadores em equipes concorrentes, a intenção é evidente - aumentar produtividade pela competição - e existe a assunção dos riscos concretos (verdadeiro dolo eventual) de ocorrência de assédio moral, em especial o descendente e o horizontal. Não deve causar surpresa ou espanto que tal modelo de organização produtiva gere condutas de assédio moral entre os empregados; em vez disso, deve-se ver com clareza que o assédio é um efeito ordinário e de certa forma esperado do referido modelo. Daí a relevância da atuação preventiva proposta neste trabalho: a prevenção deve ser focada nos modelos organizacionais que propiciem as hostilidades psicológicas no âmbito do trabalho.

É nesse sentido a concepção de um assédio organizacional: a empresa estrutura as relações interpessoais de uma forma tal que as hostilidades entre os

\footnotetext{
186 "Segundo Sennett a lógica do trabalho atual prima pelo 'trabalho em equipe', [...] porém complementa que tais 'equipes' são fortemente permeadas por relações sociais superficiais. Tais relações superficiais acabam por propiciar, e até mesmo incentivar, a competição sem limites e a rivalidade entre os trabalhadores dos mais diversos níveis hierárquicos. Este ambiente de competitividade extrema muitas vezes é instituído pelos próprios modelos e políticas de gestão da empresa. [...] A empresa incentiva tal concorrência 'estimulante' entre os próprios colaboradores tendo como principal objetivo o aumento da produtividade. Nesta situação observa-se que as práticas e o objetivo da empresa podem inclusive vir a caracterizar uma situação de assédio moral organizacional." (EBERLE, André Davi. SOBOLL, Lis Andrea Pereira. CREMASCO, Maria Virgínia Filomena. Compreensões sobre o assédio moral no trabalho a partir da psicodinâmica do trabalho. In: SOBOLL e GOSDAL, 2009, p. 110-111).

187 Afinal, o "assédio é uma patologia da solidão. As pessoas isoladas são prioritariamente as mais ameaçadas. As que possuam aliados ou amigos estão mais protegidas.” (HIRIGOYEN, 2009b, p. 51). No mesmo sentido o entendimento de MENEZES (2010, p. 4).
} 
trabalhadores nada mais são do que os desdobramentos esperados da própria $\operatorname{organização~}^{188}$.

Assim, é possível conceber mecanismos de tutela jurisdicional que atuem nas estruturas perversas da organização e, com isso, previnam casos de assédio moral no trabalho.

\subsubsection{Assédio moral vertical descendente}

$\mathrm{O}$ assédio moral vertical descendente envolve como vítima um subordinado e como agressor o superior hierárquico ou o patrão, que abusa de seu poder em face do primeiro $^{189}$. É por certo a modalidade mais comum de assédio moral na relação de emprego, pois nela a vítima está mais desprotegida, uma vez que a sujeição por temor da perda do emprego se acentua ${ }^{190}$.

Muitas vezes o assédio moral praticado pelo patrão ou pelo superior hierárquico esconde a fragilidade da pessoa que ocupa posto de comando na organização, que pode se ver ameaçada pela vítima, seja em razão do potencial profissional dela, seja mesmo por ter motivos para desconfiar que a vítima não compõe homogeneamente o grupo de trabalho. Pode ocorrer também que a empresa adote de forma institucionalizada a chamada gestão por estresse ${ }^{191}$, e com isso estimule a prática do assédio moral pelos

\footnotetext{
${ }^{188}$ Nas palavras de CERQUEIRA, “a gestão, em si, é o agente agressor” (2012, p. 32).

189 "Esse tipo de assédio é proveniente do empregador, compreendido na expressão o empregador propriamente dito, bem como qualquer outro superior hierárquico" (ALKIMIN, 2009, p. 61).
}

190 "Verifica-se o assédio moral de tipo vertical durante a execução do contrato de trabalho, quando a violência psicológica é praticada de cima para baixo, deflagrada pela direção da empresa ou por um superior hierárquico contra o empregado." (GUEDES, 2008, p. 39).

${ }^{191}$ A gestão por estresse propicia as condições de surgimento do assédio moral no ambiente de trabalho. "A pressão da chefia surge como fonte de tensão, medo e ansiedade, estimulando a aceleração do ritmo, a sobrecarga física e a rivalidade entre os colegas, na busca do reconhecimento dos chefes. Para evitar demissão e punição, o trabalhador se dispõe a cumprir a transpor as quotas e, para manter o chefe o mais longe possível, busca realizar a tarefa o melhor possível. A vigilância de gestos e atos incomoda bastante o trabalhador e, se perdurar no tempo, pode ensejar um processo de fadiga." (DINIZ, 2003, p. 90). Paulo Eduardo Vieira de OLIVEIRA salienta que "a pressão competitiva, os prazos a cumprir, os objetivos a serem alcançados dentro da previsão orçamentária, a redução de custos e o aumento da produtividade, a indefinição de procedimentos, as margens de lucro a serem alcançadas e o grande número de solicitações diárias que requerem atenção de forma continuada, são um risco permanente da ocorrência de estresse profissional e da degeneração dos ambientes de trabalho e dos níveis de produtividade” (2013, p. 17). 
gestores em face de seus subordinados, o que pode gerar incrementos de produtividade à empregadora, na visão do empresário ${ }^{192}$.

Não se deve perder de vista, portanto, nos moldes do desenvolvimento do tópico anterior, a perspectiva organizacional do assédio moral. A análise simplista de atribuir toda a origem e a motivação do assédio moral nas empresas a perturbações e características meramente individuais das pessoas envolvidas contribui para manter submerso o problema mais relevante a resolver nessa questão, que é a conduta da organização. Esta deve esforçar-se por manter o respeito à dignidade e aos direitos fundamentais dos empregados, inclusive no que diz com a violência psicológica. E o discurso da impunidade empresarial não colabora com essa finalidade.

No Brasil, existe ainda outro fator que contribui para a frequência da prática do assédio moral vertical descendente: é o fator cultural das relações autoritárias de trabalho.

A colonização brasileira pelos portugueses foi marcada pela exploração econômica. E o problema do trabalho foi, desde o início, de crucial importância. O explorador português tinha à sua frente um território imenso, infinitamente maior que o território de seu país de origem, e que oferecia recursos naturais valiosos, em farta quantidade. Eram necessários muitos braços para o trabalho indispensável à retirada das riquezas oferecidas pelo novo mundo.

A primeira opção foi o uso do trabalho dos índios nativos. Os índios de início colaboraram $^{193}$, mas depois de certo tempo começaram a recusar e, às vezes, fugir dos

\footnotetext{
192 “A empresa deixa um indivíduo dirigir seus subordinados de maneira tirânica ou perversa, ou porque isto lhe convém, ou porque não lhe parece ter a menor importância.” (HIRIGOYEN, 2009a, p. 75).

193 Caio PRADO JÚNIOR, ao tratar da incipiente exploração do pau-brasil nos primeiros anos da colonização, referiu que "é graças aliás à presença relativamente numerosa de tribos nativas no litoral brasileiro que foi possível dar à indústria um desenvolvimento apreciável. Só as tripulações dos navios que efetuavam o tráfico não dariam conta, a não ser de forma muito limitada, da árdua tarefa de cortar árvores de grande porte como o pau-brasil, que alcança um metro de diâmetro na base do tronco e 10 a 15 metros de altura, transportá-las até a praia e daí às embarcações. Não foi difícil obter que os indígenas trabalhassem; miçangas, tecidos e peças de vestuário, mais raramente canivetes, facas e outros pequenos objetos os enchiam de satisfação; e em troca dessa quinquilharia, de valor ínfimo para os traficantes, empregavam-se arduamente em servi-los.” (História econômica do Brasil. Atualização de 1970. São Paulo: Brasiliense, 2008, p. 25).
} 
brancos que lhes punham ao trabalho forçado ${ }^{194} 195$. A partir de então, adota-se o sistema de trabalho que vigoraria por muito tempo e definiria traços relevantes da futura sociedade brasileira: a escravidão, abastecida pelo tráfico de escravos africanos.

O sistema do escravismo, que durou mais de três séculos no Brasil e foi abolido oficialmente apenas em 1888, moldou culturalmente a sociedade brasileira no que tange às relações de trabalho. A relação de trabalho passa a ser vista e compreendida como relação de dominação, relação de poder. Tanto isso é certo que, após a abolição, com o aumento vertiginoso do uso da mão de obra de imigrantes europeus, alguns países daquele continente deliberaram desestimular as emigrações de seus cidadãos para o Brasil, em razão do péssimo tratamento que lhes era dispensado pelos empregadores brasileiros, acostumados que foram a lidar com escravos, não com homens livres ${ }^{196}$.

De fato, o escravo não era visto como pessoa, e sim como patrimônio ${ }^{197}$. Não tinha, pois, dignidade. O patrão não se preocupava com seus sentimentos, e se atribuía o direito de usar a força física quando lhe aprouvesse, inclusive para infligir castigos ao escravo. Era inimaginável, em um sistema como esse, um discurso de igualdade e respeito à dignidade do trabalhador.

Pois bem. A escravidão foi abolida, mas, como dito acima, ela moldou a cultura brasileira nas relações de trabalho ${ }^{198}$. As relações trabalhistas no Brasil são, até

\footnotetext{
${ }^{194}$ PRADO JÚNIOR, 2008, p. 35; VIANA, 1996, p. 32.

195 Relata Sérgio Buarque de HOLANDA que os índios "dificilmente se acomodavam, porém, ao trabalho acurado e metódico que exige a exploração dos canaviais. Sua tendência espontânea era para atividades menos sedentárias e que pudessem exercer-se sem regularidade forçada e sem vigilância e fiscalização de estranhos. [...] O resultado eram incompreensões recíprocas que, de parte dos indígenas, assumiam quase sempre a forma de uma resistência obstinada, ainda quando silenciosa e passiva, às imposições da raça dominante" (Raízes do Brasil. 26 ed. São Paulo: Companhia das Letras, 1995, p. 48).

${ }^{196}$ Com efeito, em meado do século XIX “alarma-se a opinião pública na Europa, em particular na Alemanha e em Portugal, donde provinha então a maior parte da imigração para o Brasil, com a sorte aqui reservada para seus compatriotas emigrados. Sucedem-se os inquéritos oficiais e, em grande maioria, eles são desfavoráveis e desaconselham a emigração. Desencadeia-se então contra ela forte campanha, e a emigração para o Brasil chega a ser proibida na Alemanha em 1859." (PRADO JÚNIOR, 2008, p. 188).
}

197 “[O] escravo não tinha o reconhecimento de pessoa humana, tão menos tinha vontade própria; era tratado como res; sua relação com seu amo era uma 'autêntica relação real de domínio"” (ALKIMIN, 2009, p. 18). Cf. também OLEA, 1997, p. 152.

${ }^{198}$ SOUTO MAIOR, 2000, p. 61-64. 
hoje, marcadas pelo autoritarismo e pelo abuso de poder. Na expressão de André Luiz Souza AGUIAR,

a classe empresarial brasileira não está habituada a negociar e desenvolver técnicas gerenciais para a sedução e interação do empregado. Ao contrário, suas respostas são sempre obtidas por meio do autoritarismo e pela imposição do estilo próprio de administrar. [...] A desumanização das relações de trabalho ainda está impregnada dos valores organizacionais brasileiros: o grito forte do senhor de engenho ainda retumba no portão da fábrica!. ${ }^{199}$

Hoje, o uso da violência física perdeu totalmente a legitimidade, mas a violência psicológica assumiu o papel de ferramenta gerencial na hierarquia trabalhista brasileira. Tal é o papel do assédio moral como substituto da violência física no contexto cultural atual $^{200}$.

Assim, se atualmente não se pode pensar em infligir dores físicas aos empregados no ambiente do trabalho, como se fazia outrora, usam-se palavras e gestos, ironias e humilhações, para lhes causar dores psicológicas, isto é, instaura-se o assédio moral. É importante salientar a correlação entre o sofrimento físico gerado no passado e o sofrimento psíquico gerado hoje, como ferramentas de gestão nas mãos de empregadores e superiores hierárquicos. Essa correlação se afigura essencial para uma compreensão adequada do assédio moral nas empresas brasileiras.

Em perspectiva ampla, o assédio moral vertical descente, embora possa apresentar uma vítima perfeitamente definida, gera seus efeitos sobre todos os empregados do ambiente. A partir do momento em que um dos trabalhadores do grupo é perseguido pelo patrão ou pelo gerente, os demais trabalhadores têm a tendência de afastar-se da vítima, para evitar sofrer junto com ela; com isso, tentam evitar a virtual condição de próxima vítima.

\footnotetext{
199 AGUIAR, André Luiz Souza. Assédio moral: o direito à indenização pelos maus-tratos e humilhações sofridos no ambiente do trabalho. 2 ed. São Paulo: LTr, 2006, p. 70, grifos do original.

200 "Em substituição ao conflito - enquanto renovação e reorganização do dinamismo organizacional tornou-se corriqueiro o assédio moral nas relações interpessoais das organizações. Ao se cultivarem intrigas, brigas, discussões, formação de grupos e com o fomento da hostilidade, sem um poder regulador ético, constrói-se espaço para que atos violentos como o assédio moral floresçam e comecem a marcar as relações interpessoais com antagonismo e rivalidade." (AGUIAR, 2006, p. 26-27).
} 
Essa circunstância gera um duplo efeito. De um lado, fortalece o poder do assediador, que percebe ter "encurralado" a vítima na solidão, na ausência total de apoio. De outro lado, e pelo mesmo motivo, aumenta o sofrimento da vítima, que não tem para quem pedir ajuda na situação vivenciada.

Como círculo vicioso, esses efeitos induzem mais e mais obediência dos colegas da vítima ao poder do assediador. A solidariedade dos trabalhadores fica esvaziada pelo medo, pois cada um deles também teme pelo seu posto de trabalho e pela própria saúde, que certamente pode ser afetada pela conduta do assediador ${ }^{201}$.

É nesse contexto que a prática do assédio moral funciona como elemento de poluição do meio ambiente do trabalho, fazendo o problema extrapolar o âmbito meramente individual dos sujeitos envolvidos, e assumir foros de interesse coletivo. Desse aspecto se tratará com mais vagar, porém, em tópico específico ${ }^{202}$.

\subsubsection{Assédio moral horizontal}

O assédio moral horizontal é aquele em que o assediador (comumente mais de um assediador) ocupa na organização o mesmo nível hierárquico da vítima. Logo, é uma espécie de assédio moral em que não existe, a priori, abuso de poder hierárquico pelo patrão ou por um superior ${ }^{203}$.

Não raro, o assédio horizontal é causado pela competitividade exacerbada ${ }^{204}$, fomentada por diretrizes da gestão empresarial. Colegas que disputam promoções ou

\footnotetext{
201 “A ameaça de perder o emprego dá azo à arrogância e ao cinismo como métodos de gerenciamento. O medo gera condutas de obediência, ou mesmo de submissão tanto da pessoa visada como dos colegas que deixam que o assédio moral aconteça, que não querem ver o que se passa em torno deles. Quem está presente ou por perto teme, caso se prontifique a defender a vítima, ser estigmatizado, perseguido e jogado na próxima onda de despedidas." (THOME, 2009, p. 137)

${ }^{202}$ Vide a abordagem das questões afetas ao meio ambiente do trabalho no tópico 4.3, infra.

203 "O assédio horizontal é a perseguição desencadeada pelos colegas de trabalho. [...] Esta espécie de psicoterror tanto ocorre de forma individual quanto coletiva." (GUEDES, 2008, p. 40). Cf. também ALKIMIN, 2009, p. 63.

${ }^{204}$ MENEZES, 2010, p. 4.
} 
prêmios por produtividade podem tender ao assédio uns contra os outros - o que não deixa de transparecer a perversidade da organização como um todo ${ }^{205}$.

Assim, é preciso sempre retomar a ideia de que a organização não é, em geral, inocente nos episódios de assédio moral que ocorrem no âmbito das relações de trabalho. Ainda que se trate de assédio moral horizontal, a conduta da organização pode se mostrar fundamental para a geração da situação de violência psicológica (em razão das técnicas de administração ou gestão por estresse ou competitividade), ou sua continuidade (a omissão das chefias, que veem na tensão psicológica dos subordinados a oportunidade de incremento de produtividade).

Por outro lado, existe uma tendência humana para a violência psicológica, para a prática de atos perversos em determinadas situações, a qual explica muitos dos episódios de assédio moral horizontal. Tal espécie de assédio é recorrente, por exemplo, entre crianças, dentro ou fora do âmbito escolar, o que tem chamado a atenção de educadores nos últimos anos, e não deixa de ser um dado empírico a amparar a hipótese de que o ser humano é, em si, um assediador em potencial.

Por exemplo, a inveja entre profissionais é um importante fator desencadeante de assédio moral horizontal. O sucesso de um trabalhador pode, de certa forma, provocar reações de inveja em seus colegas do mesmo nível hierárquico, de modo a estimulá-los a praticar hostilidades contra o primeiro, que se destaca de forma indesejável ${ }^{206}$.

Em um caso como esse, se de um lado a culpa da organização na geração da situação de assédio moral é reduzida, de outro lado não se deve perder de vista a responsabilidade do empregador de manter um meio ambiente do trabalho sadio e equilibrado, o que significa dizer, livre de hostilidades psicológicas. Mesmo na hipótese,

205 "Mesmo quando a perseguição é horizontal (um colega agredindo outro colega), a chefia não intervém. Ela se recusa a ver, ou deixa as coisas acontecerem. [...] O conflito, na verdade, degenera porque a empresa se recusa a interferir" (HIRIGOYEN, 2009a, p. 67). "Pode acontecer que o empregador, visando ao mercado competitivo e à lucratividade, não se preocupe com organizar o trabalho com base na valorização das relações interpessoais e prevenção de condutas por parte dos empregados que tornem o ambiente de trabalho degradante e hostil. E se assim não o faz, fica indiferente às práticas de assédio moral que um colega infringe sobre o outro" (ALKIMIN, 2009, p. 46).

206 "Um dos pilares para a ocorrência do assédio moral numa organização é a inveja, intrinsecamente vinculada ao poder e ao abuso narcísico.” (AGUIAR, 2006, p. 37, grifo do original). 
portanto, de uma situação de assédio moral horizontal ligada a fatores individuais dos trabalhadores envolvidos, a organização tem a incumbência de atuar preventivamente e coibir a violência psicológica, de modo a preservar a integridade e a dignidade de seus empregados.

\subsubsection{Assédio moral vertical ascendente}

Trata-se da espécie mais rara de assédio moral ${ }^{207}$. Nela, um superior hierárquico sofre assédio de seus subordinados. Há relatos de casos de assédio ascendente, por exemplo, em relação a um novo chefe de uma equipe já entrosada e acostumada a um sistema de trabalho que o novato propõe mudar ${ }^{208}$. A tendência a conservar o modo de vida do grupo gera a tensão, e a exclusão do elemento novo passa a ser buscada, por meio de condutas hostis.

Também aqui, no assédio vertical ascendente, pode ser a inveja o elemento propulsor das condutas hostis. Tal situação ocorre em casos nos quais um dos subordinados é promovido a um posto superior e passa a ser vítima dos antigos colegas. HIRIGOYEN relata, nesse sentido, o caso de uma secretária-assistente que é promovida para um cargo de responsabilidade e, a partir daí, se vê como alvo das hostilidades das secretárias com quem trabalhava nos anos anteriores ${ }^{209}$.

Reitera-se nesse aspecto a observação feita no tópico anterior, no sentido da necessidade da conduta preventiva da organização, também quanto ao assédio moral em sua modalidade vertical ascendente.

\footnotetext{
${ }^{207}$ HIRIGOYEN, 2009a, p. 74.

208 “A substituição de um superior que exerça liderança carismática em relação à equipe pode trazer, para o substituto, graves dificuldades de adaptação, especialmente se este adota estilo menos exuberante e conquistador. Isso se acentua quando a pessoa substituída era, também, reconhecida por sua perícia e experiência e participou ativamente, com a equipe, de situações difíceis no passado, as quais ataram fortes laços emocionais entre ela e seus liderados." (FIORELLI, José Osmir. FIORELLI, Maria Rosa. MALHADAS JÚNIOR, Marcos Júlio Olivé. Assédio moral: uma visão multidisciplinar. São Paulo: LTr, 2007, p. 62).

${ }^{209}$ HIRIGOYEN, 2009a, p. 74-75.
} 


\subsection{Meio ambiente do trabalho e assédio moral}

A proposta deste tópico é realçar a visão do assédio moral como fenômeno diretamente ligado ao meio ambiente do trabalho, pois o assédio polui o ambiente e gera, por isso, consequências jurídicas que extrapolam os limites da relação estrita agressorvítima.

$\mathrm{Na}$ atual ordem constitucional, o meio ambiente equilibrado é direito fundamental de todas as pessoas. O art. 225 da Constituição Federal dispõe, em seu caput, que "todos têm direito ao meio ambiente ecologicamente equilibrado, bem de uso comum do povo e essencial à sadia qualidade de vida, impondo-se ao Poder Público e à coletividade o dever de defendê-lo e preservá-lo para as presentes e futuras gerações".

O art. 200 da CF faz menção expressa ao meio ambiente do trabalho, quando dispõe que compete ao Sistema Único de Saúde "colaborar na proteção do meio ambiente, nele compreendido o do trabalho" (inciso VIII).

Assim, o meio ambiente do trabalho é um aspecto da proteção geral ambiental elevada, pela Constituição Federal, a patamar de direito fundamental ${ }^{210}$.

\footnotetext{
210 "Dessa forma, o meio ambiente equilibrado, muito embora previsto no art. 225 da CF [...], trata-se indubitavelmente de um direito fundamental, posto que inerente ao direito à vida e à vida com qualidade. A proteção ambiental, que visa tutelar a qualidade do meio ambiente em função da qualidade de vida, é uma forma de direito fundamental da pessoa humana, direito este que foi reconhecido pela Declaração do Meio Ambiente, adotada pela Conferência das Nações Unidas, em Estocolmo, em junho de 1972, cujos vinte e seis princípios constituem prolongamento da Declaração Universal dos Direitos do Homem.” (PADILHA, Norma Sueli. Do meio ambiente do trabalho equilibrado. São Paulo: LTr, 2002, p. 19).

"O meio ambiente está indubitavelmente ligado aos direitos humanos. O respeito ao direito ao meio ambiente equilibrado implica, necessariamente, a defesa do direito à vida, que é o mais básico dos direitos fundamentais" (RENAULT, Luiz Otávio Linhares. MUNIZ, Mirella Karen de Carvalho Bifano. "Meio ambiente e vida: direitos fundamentais convergentes com o direito do trabalho e com o processo do trabalho". In: SENA, Adriana Goulart de (coord). Dignidade humana e inclusão social: caminhos para a efetividade do direito do trabalho no Brasil. São Paulo: LTr, 2010, p. 63). Cf., no mesmo sentido: SILVA, J. A., 2008, p. 126-135; MELO, Raimundo Simão de. Direito ambiental do trabalho e a saúde do trabalhador: responsabilidades legais, dano material, dano moral, dano estético. 4 ed. São Paulo: LTr, 2010, p. 32-34.
}

Assim também o entendimento da jurisprudência: "Assédio moral. O meio ambiente do trabalho do sadio e hígido é direito constitucionalmente assegurado. O empregado não pode ser levado ao desgaste físico e/ou emocional a tal ponto de lhe causar sofrimento totalmente desproporcional à mera prestação dos serviços contratados. As esferas pessoal, privada e íntima do ser é [sic] inviolável e o contrato laboral jamais dá poder ao empregador de atacá-las sob qualquer circunstância. Tais atitudes remontam-se à Idade Média e aos anos sombrios dos primórdios do direito do trabalho, não sendo hoje tolerável no estado constitcional." (TRT/2a Região. RO 00011371420115020046, 14ª turma, Rel. Maria Elizabeth Mostardo Nunes, DOE 14.12.2012). 
Não é tarefa simples definir o que deve ser entendido por meio ambiente. A Lei 6.938/1981 (que dispõe sobre a Política Nacional do Meio Ambiente) define meio ambiente como "o conjunto de condições, leis, influências e interações de ordem física, química e biológica, que permite, abriga e rege a vida, em todas as suas formas" (art. $3^{\circ}$, inciso I) ${ }^{211}$.

Norma Sueli PADILHA elabora um conceito amplo, segundo o qual

o meio ambiente é tudo aquilo que cerca um organismo (o homem é um organismo vivo), seja o físico (água, ar, terra, bens tangíveis pelo homem), seja o social (valores culturais, hábitos, costumes, crenças), seja o psíquico (sentimento do homem e suas expectativas, segurança, angústia, estabilidade), uma vez que os meios físico, social e psíquico são os que dão as condições interdependentes, necessárias e suficientes para que o organismo vivo (planta ou animal) se desenvolva na sua plenitude. $^{212}$

É importante a definição fornecida pela autora, uma vez que sua formulação é explícita no tocante à inclusão do meio psíquico na noção de meio ambiente, além dos meios físico e social ${ }^{213}$. Nessa perspectiva, põe-se em relevo a pertinência do estudo do assédio moral como fenômeno diretamente ligado ao meio ambiente do trabalho.

Celso FIORILLO menciona expressamente o equilíbrio ambiental e a ausência de comprometimento da incolumidade físico-psíquica dos trabalhadores. Para ele,

Constitui meio ambiente do trabalho o local onde as pessoas desempenham suas atividades laborais, sejam remuneradas ou não, cujo equilíbrio está baseado na salubridade do meio e na ausência de agentes que comprometam a incolumidade físico-psíquica dos trabalhadores. ${ }^{214}$

\footnotetext{
${ }^{211}$ Cf. MELO, 2010, p. 29; MORAES, Monica Maria Lauzid de. O direito à saúde e segurança no meio ambiente do trabalho. São Paulo: LTr, 2002, p. 24-25; SADY, João José. Direito do meio ambiente de trabalho. São Paulo: LTr, 2000, p. 14-16.

${ }^{212}$ PADILHA, 2002, p. 20-21.

${ }^{213}$ No mesmo sentido é a doutrina de Ana Paola Santos Machado DINIZ (2003, p. 43). Para SADY, "a partir de tal concepção, o complexo de questões que envolvem o bem-estar do obreiro no local de trabalho expande-se, evoluindo de mero cipoal de normas protetivas para ser pensado como um microssistema referenciado a um interesse constitucionalmente tutelado" (2000, p. 21).
}

214 FIORILlO, Celso Antonio Pacheco. Curso de direito ambiental brasileiro. 3 ed. São Paulo: Saraiva, 2002, p. 22-23. 
Como se vê, não se pode pretender uma compreensão estrita do conceito de meio ambiente do trabalho, de modo a abranger apenas aspectos físicos; o meio ambiente do trabalho é muito mais do que isso ${ }^{215}$.

É nesse sentido que foram expostas, anteriormente, as consequências do assédio moral não apenas sobre a vítima direta, mas também sobre os colegas de trabalho, que são afetados pela disseminação do medo no meio ambiente ${ }^{216}$. A isso se deve denominar poluição do meio ambiente do trabalho, em seu aspecto psicológico ${ }^{217}$.

Com efeito. O empresário que em sua atividade explora mão de obra assalariada assume o dever de fornecer aos empregados um meio ambiente do trabalho equilibrado e sadio ${ }^{218} 219$. Com se viu, esse é um direito fundamental dos trabalhadores, porque o equilíbrio do meio ambiente está ligado ao próprio direito à vida - e à qualidade de vida. Nesse equilíbrio ambiental deve-se pensar nos aspectos físicos (ruídos, umidade, poeira, fumaça, ergonomia), mas também e sobretudo nos aspectos psicológicos ${ }^{220}$.

\footnotetext{
215 "Na busca do conceito de meio ambiente do trabalho, procura-se conjugar a ideia de local de trabalho à de conjunto de condições, leis, influências e interações de ordem física, química e biológica, que incidem sobre o homem em sua atividade laboral. O conceito transcende a concepção meramente espacial (local de trabalho como elemento do contrato de trabalho) e rejeita a dicotomia natural x artificial." (FIGUEIREDO, Guilherme José Purvin de. Direito ambiental e a saúde dos trabalhadores. 2 ed. São Paulo: LTr, 2007, p. 40, com grifos no original).
}

216 “[Essa] prática contamina o ambiente de trabalho, violando a garantia constitucional de um meio ambiente do trabalho sadio e equilibrado, além de agredir a dignidade da pessoa humana do trabalhador" (ALKIMIN, 2009, p. 37).

217 "Entendemos que a proteção constitucional ao meio ambiente traduz-se, também, como defesa da humanização do trabalho, não só limitado à preocupação com as concepções econômicas que envolvem a atividade laboral, mas resgatando a finalidade do trabalho como espaço de construção de bem-estar, de identidade e de dignidade daquele que labora." (PADILHA, 2002, p. 19).

218 "Uma das obrigações fundamentais do empregador é propiciar aos empregados um meio ambiente do trabalho sadio. Trata-se de um dever instituído por diversas normas jurídicas, muitas com nível constitucional. Este dever decorre da exploração da atividade econômica e dela obtém o lucro, que não pode ser conseguido sobre a desconsideração da dignidade da pessoa humana, constitucionalmente protegida pelos artigos $1^{\circ}$, III, e 170, caput, ambos da Constituição Federal de 1988." (LIMA, Firmino Alves. Assédio sexual e o meio ambiente do trabalho. Revista da Amatra XV, número 4/2011, p. 154). "Destarte, impõe-se ao empregador a obrigação de assegurar ao empregado um ambiente de trabalho sadio, hígido e livre de qualquer abuso ou infortúnio." (DALLEGRAVE NETO, 2008, p. 213). Cf. também DINIZ, 2003, p. 47.

219 "A preservação do meio ambiente, inclusive a do meio ambiente no local de trabalho ou decorrente do trabalho, é pauta permanente de todos os escalões sérios, tanto do governo quanto da sociedade civil." (BELTRAN, 2002, p. 231).

220 "[O] stress profissional passou a ser considerado um grande mal para a saúde do trabalhador e para o mundo do trabalho, sendo até mesmo tachado de mal do século XX, fruto da moderna organização do trabalho" (ALKIMIN, 2009, p. 34). 
Um excursus necessário. As doenças mentais têm tido sua incidência aumentada $^{221}$, e há motivos para considerar a influência de causas profissionais nesse aumento.

Aqui reside um problema que tem sido recorrente na prática forense. Há muitos processos em que os trabalhadores alegam que foram acometidos de doenças mentais ou psicológicas por causa do trabalho e, por isso, postulam indenização e estabilidade no emprego em face de seus empregadores, haja vista o alegado caráter ocupacional das enfermidades. As empresas reclamadas, obviamente, contestam a relação de causalidade entre o trabalho e a doença, e a perícia médica realizada, não raro, afirma que é impossível determinar se existe nexo causal entre a doença e o trabalho desempenhado ${ }^{222}$.

Tais doenças têm uma causalidade dita multifatorial, e é bastante difícil separar os fatores determinantes de sua eclosão em certas situações ${ }^{223}$. Resultado: os empregadores são absolvidos, por ausência de provas.

Apenas para não deixar de mencionar esse aspecto do problema, mas sem esquecer que o objeto da pesquisa não alcança a respectiva resolução, a visão ambiental do assédio moral pode colaborar cientificamente também em relação a isso. Se a chamada multifatorialidade causal das doenças psicológicas impede que se isole apenas uma ou algumas causas como determinantes para a eclosão da enfermidade, não se pode deixar de reconhecer que na maioria das vezes será impossível afirmar, de outro lado, que o trabalho não contribuiu para a doença do trabalhador. Ora, nesse caso, a análise do meio ambiente

\footnotetext{
${ }^{221}$ Segundo SELIGMANN-SILVA et al., com base em dados da OMS, "os transtornos mentais chamados menores atingem $30 \%$ dos trabalhadores ocupados e os transtornos mentais graves, cerca de 5\% a $10 \%$ " (2010, p. 188). Cf. também TURTE, 2011, p. 61.

${ }^{222}$ Sebastião Geraldo de OLIVEIRA refere, a propósito, que o estabelecimento do nexo de causalidade das doenças ocupacionais enseja uma investigação complexa, e conclui ser preferível basear-se em um "grau elevado de probabilidade" a exigir a certeza absoluta nessa matéria (Indenizações por acidente do trabalho ou doença ocupacional. 3 ed. São Paulo: LTr, 2007, p. 141).

223 “A organização do trabalho, a qualidade das relações humanas, sobretudo com a chefia, as condições de higiene e segurança do ambiente de trabalho, além de fatos externos como ameaça de desemprego ou subemprego interferem demasiadamente no sentimento do trabalhador quanto ao valor do seu trabalho para a empresa e para a sociedade como um todo, depreciando sua qualidade de vida." (DINIZ, 2003, p. 47).
} 
do trabalho real, a que estava submetido o reclamante, poderá dar uma suficiente compreensão da relevância do aspecto laboral no desencadeamento da doença. Um meio ambiente psicologicamente poluído seria, presumidamente, elemento causal de uma doença psicológica, o que ampararia os deveres jurídicos decorrentes do caráter ocupacional da doença.

Fecha o parêntese.

O assédio moral é, portanto, um fator de poluição do meio ambiente do trabalho, em seu aspecto psicológico ${ }^{224}$. Essa ideia é fundamental. Ainda que não se trate de assédio organizacional, aquele em que o agressor é a própria empresa como um todo, a omissão da organização em relação à conduta hostil de um gerente, de colegas e mesmo de subordinados acarreta a sua responsabilidade, pois o empregador nesses casos tem o dever de agir; agir no sentido de construir o meio ambiente do trabalho equilibrado, livre da poluição psicológica causada pela prática do assédio moral.

Omitindo-se em relação ao assédio moral praticado, o empregador permite a poluição psicológica no meio ambiente do trabalho, como se vem de sustentar.

Segundo a doutrina, o direito ao meio ambiente do trabalho equilibrado tem natureza difusa ${ }^{225}$. Encontra-se na Lei 8.078/1990 (Código de Proteção e Defesa do Consumidor - CDC) o regime dessa classificação de direitos. Segundo o inciso I do parágrafo único do art. 81 , são direitos ou interesses difusos "os transindividuais, de natureza indivisível, de que sejam titulares pessoas indeterminadas e ligadas por circunstâncias de fato" ${ }^{226}$.

\footnotetext{
${ }^{224}$ MENEZES, 2010, p. 2.

${ }^{225}$ Para PADILHA, "o equilíbrio do meio ambiente do trabalho, como parte integrante e importante do meio ambiente considerado como um todo, constitui, sem sombra da dúvida, um direito essencialmente difuso" (2002, p. 50). No mesmo sentido: CAPPELLETTI e GARTH, 1988, p. 26; FELICIANO, 2011, p. 146-147; SADY, 2000, p. 25.
}

${ }^{226}$ CORREIA, 1994, p. 18-19; FAVA, 2008, p. 35-37. 
Parece adequado o enquadramento do direito ao meio ambiente do trabalho equilibrado como direito difuso ${ }^{227}$. A única preocupação é com uma possível interpretação restritiva quanto à legitimidade para agir em caso de violação do direito. Na linha da exposição da presente pesquisa, essa legitimidade deve ser a mais ampla possível, admitindo-se o ingresso de demandas coletivas e também individuais.

Se o assédio moral, por um lado, constitui uma poluição labor-ambiental e pode dar azo à tutela coletiva judicial, por outro lado não pode deixar de ensejar a possibilidade da demanda individual do trabalhador que se sinta afetado. A ação, nessa hipótese, tem por objetivo defender o direito fundamental do trabalhador em questão, seja ele a vítima direta da conduta hostil ou um membro da coletividade afetada pela poluição psicológica no ambiente.

Recorde-se que a classificação engendrada no art. 81 do CDC é muito dependente da pretensão exercida em juízo. Ou seja, é possível haver, para o mesmo fato, uma pretensão de tutela de interesse difuso, ou de interesse coletivo em sentido estrito, ou de interesse individual homogêneo; ou, ainda, pode haver uma pretensão complexa que envolva a tutela de todas essas espécies de interesses ${ }^{228}$.

Por fim, é preciso ressaltar o princípio básico e fundamental do direito ambiental, cujo conteúdo interessa diretamente ao desenvolvimento desta pesquisa: o princípio da prevenção ${ }^{229}$.

\footnotetext{
227 "Na verdade, podemos afirmar que o meio ambiente do trabalho equilibrado transcende o interesse coletivo, para atingir até mesmo o interesse público, pois diz respeito ao bem comum." (ALKIMIN, 2009, p. 30). Cf. também MELO, 2010, p. 35.

Rodolfo PAMPLONA FILHO conclui que "a preservação de boas condições de trabalho configura-se, portanto, como um interesse de todos, de caráter transindividual, conformado em um direito indivisível, cujo titular é um sujeito indeterminado e indeterminável” (2002, p. 120).

228 “Outra confusão recorrente precisa ser desfeita: o mesmo interesse não pode ser simultaneamente difuso, coletivo e individual homogêneo, pois se trata de espécies distintas. O que pode ocorrer é que uma única combinação de fatos, sob uma única relação jurídica, venha a provocar o surgimento de interesses transindividuais de mais de uma categoria, os quais podem até mesmo ser defendidos numa única ação civil pública ou coletiva. Assim, de um único evento fático e de uma única relação jurídica consequente, é possível advirem interesses múltiplos." (MAZZILI, Hugo Nigro. A defesa dos interesses difusos em juízo. 16 ed. São Paulo: Saraiva, 2003, p. 54).

${ }^{229}$ Similar ao princípio da prevenção é o princípio da precaução, que também tem forte incidência no direito ambiental. FELICIANO esclarece que enquanto "o princípio da prevenção atua no marco da certeza científica", de outro lado o "princípio da precaução atua além dessas fronteiras, preordenando a conduta de menor risco em contextos de relativa imponderabilidade científica". (2011, p. 144). Sobre o assunto, cf. também RENAULT, 2010, p. 71; MELO, 2010, p. 52-58.
} 
As normas ambientais têm por fundamento e finalidade última a prevenção, uma vez que as lesões ao meio ambiente, via de regra, não comportam a reparação devida, apenas uma imposição de pagamento de soma em dinheiro que de forma alguma alcançará a tutela do bem que deveria ser protegido de maneira eficaz ${ }^{230}$.

Daí a importância que assume a prevenção. Em matéria ambiental, é para ela que devem convergir todos os esforços ${ }^{231}$.

Nesse contexto, o uso da tutela inibitória mostra-se fundamental. Para o aspecto diretamente envolvido nesta pesquisa, a tutela inibitória do assédio moral na relação de emprego tem por finalidade assegurar o meio ambiente do trabalho, protegê-lo contra a poluição e degradação causadas pela prática sistemática de condutas hostis.

À luz, portanto, do direito ambiental e de suas garantias constitucionais, a emissão de provimento jurisdicional inibitório de condutas de assédio moral, no âmbito da relação de emprego, nada mais é do que o esforço para atender ao princípio fundamental da prevenção. Busca-se com isso evitar a poluição labor-ambiental, e o desencadeamento de condições propícias ao surgimento de enfermidades entre os trabalhadores.

\footnotetext{
230 "De fato, a prevenção é preceito fundamental, uma vez que os danos ambientais, na maioria das vezes, são irreversíveis e irreparáveis." (FIORILLO, 2002, p. 36). Segundo PADILHA, "a ótica que orienta todo o direito ambiental assenta-se na prevenção. É o direito que não se contenta, assim, em reparar e reprimir dano ambiental, uma vez que a degradação do ambiente, como regra, é irreparável. Prevenir a ocorrência de danos ambientais é a pedra fundamental do direito ambiental.” (2002, p. 97).

231 “O princípio da prevenção encontra-se presente ainda na ótica do Poder Judiciário e da administração. Com efeito, a aplicação da jurisdição coletiva, que contempla mecanismos de tutela mais adaptados aos direitos difusos, objetivando impedir a continuidade do evento danoso, bem como a possibilidade de ajuizamento de ações que apenas visem uma atuação preventiva, a fim de evitar o início de uma degradação (através de liminares, de tutela antecipada), a aplicação do real e efetivo acesso à justiça e o princípio da igualdade real, estabelecendo tratamento paritário entre os litigantes, são instrumentos utilizados com vistas a salvaguardar o meio ambiente e a qualidade de vida." (FIORILLO, 2002, p. 38).
} 


\subsection{Assédio moral e dignidade da pessoa ${ }^{232}$}

Uma das hipóteses de partida da presente pesquisa é a de que o assédio moral consiste em um atentado à dignidade da vítima ${ }^{233}$, tendo em vista especialmente seus efeitos devastadores na vida, saúde e integridade psíquica da pessoa assediada ${ }^{234}$.

Todavia, a consistência dessa afirmação (a relação do assédio moral com a violação da dignidade humana) requer uma razoável atenção ao estudo do conteúdo jurídico do princípio da dignidade da pessoa. Até para evitar o estímulo ao seu uso como cláusula de máxima generalidade e baixa densidade normativa, que pode ser aplicada em toda e qualquer situação, para favorecer qualquer interesse.

\section{Críticas doutrinárias existem nesse sentido. Para Maria Cristina PEDUZZI o} princípio da dignidade da pessoa "tem sido continuamente empregado como fundamento para justificar distintas decisões judiciais" ${ }^{, 235}$, situação que evidenciaria uma crise de falta de segurança jurídica ${ }^{236}$.

\footnotetext{
${ }^{232}$ Não obstante a consistente explicação de COMPARATO (2013, p. 31) acerca da expressão "dignidade da pessoa humana" e o pleonasmo apenas aparente, no presente trabalho optou-se por "dignidade da pessoa", e eventualmente "dignidade humana", por se considerarem tais expressões suficientemente significativas para a compreensão da ideia.

${ }^{233}$ Nesse sentido o entendimento de MENEZES (2010, p. 2).

234 "Depois da intangibilidade da vida humana, a primeira consequência direta que se pode tirar do princípio da dignidade é o respeito à integridade física e psíquica da pessoa humana." (AZEVEDO, Antônio Junqueira de. Caracterização jurídica da dignidade da pessoa humana. Revista USP. São Paulo, n. 53, março/maio 2002, p. 97, com grifos no original).
}

${ }^{235}$ PEDUZZI, Maria Cristina Irigoyen. O princípio da dignidade da pessoa humana na perspectiva do direito como integridade. São Paulo: LTr, 2009, p. 18. Semelhante preocupação demonstra Maria Celina Bodin de MORAES: "Uma vez que a noção é ampliada pelas numerosíssimas conotações que enseja, correse o risco da generalização, indicando-a como ratio jurídica de todo e qualquer direito fundamental. Levada ao extremo, essa postura hermenêutica acaba por atribuir ao princípio um grau de abstração tão intenso que torna impossível a sua aplicação." (2003, p. 84).

${ }^{236}$ É preciso, contudo, consignar a discordância com o raciocínio global efetuado pela autora na sequência de sua monografia. Para ela, "a argumentação com base em valores não considera exclusivamente o que é correto juridicamente, mas sim o que é bom para aquela sociedade, com vistas à concretização de seus próprios fins, de modo que os argumentos de política, de funcionalidade e de finalidade social passam a se sobrepor ao argumento normativo. [...] não compete ao juiz exercer sua discricionariedade para substituir a voz do legislador [...]. Isso conduz à insegurança jurídica” (PEDUZZI, 2009, p. 56). Como foi exposto anteriormente, o presente trabalho propõe justamente a superação dessa visão estrita e positivista da função jurisdicional. 
Daí a importância do estudo do conteúdo jurídico do princípio da dignidade da pessoa, mas sem medo ou receio de aplicação dos critérios valorativos e axiológicos. É preciso demonstrar que a decisão judicial, ao expor motivação baseada na dignidade da pessoa, não está, por isso mesmo, a esconder uma atuação arbitrária do julgador. Essa cláusula fundamental possui densidade normativa e aptidão para legitimar a fundamentação jurídica ${ }^{237}$.

Segundo doutrina mais aceita, a noção contemporânea de dignidade da pessoa tem raiz no pensamento de Emanuel Kant ${ }^{238}$, para quem o homem existe como fim em si mesmo, não como meio ou instrumento; enquanto as coisas têm preço e podem ser substituídas, as pessoas possuem dignidade, o que exclui a atribuição de preço, ou a possibilidade de mera substituição ${ }^{239}$.

O conceito de dignidade da pessoa é de difícil formulação. Para SARLET, uma "conceituação clara" de dignidade da pessoa é "no mínimo difícil de ser obtida". O mesmo autor salienta que

a dignidade da pessoa humana não poderá ser conceituada de maneira fixista, ainda mais quando se verifica que uma definição dessa natureza não se harmoniza com o pluralismo e a diversidade de valores que se manifestam nas sociedades democráticas contemporâneas. ${ }^{240}$

\footnotetext{
237 O relevante papel político da magistratura atrai inclusive a responsabilidade diante de decisões fundamentadas em cláusula de razoável abstração, como a dignidade da pessoa, quando a justiça do caso concreto o exigir. "Há magistrados que invocam fundamentos teóricos para o acobertamento que dão às injustiças, alegando que o magistrado deve ser um aplicador estrito da lei, politicamente neutro e sem responsabilidade moral pelas iniquidades que possam estar contidas, com maior ou menor evidência, em suas decisões. Dizem que o magistrado não é legislador, e que se não obedecerem rigorosamente a letra da lei, desaparece a uniformidade das decisões e se abre caminho para o excesso de subjetividade dos magistrados." (DALLARI, 2007, p. 53).
}

${ }^{238}$ Cf. ALKIMIN, 2009, p. 18. "Compõe o imperativo categórico a exigência de que o ser humano seja visto, ou usado, jamais como um meio para atingir outras finalidades, mas sempre como um fim em si. Isto significa que todas as normas decorrentes da vontade legisladora dos homens precisam ter como finalidade o homem, a espécie humana enquanto tal. O imperativo categórico orienta-se, então, pelo valor básico, universal e incondicional da dignidade humana.” (MORAES, M. C. B., 2003, pp. 80-81).

${ }^{239}$ Cf. sobre o tema o escorço histórico presente na obra de SARLET, I. W. Dignidade da pessoa humana e direitos fundamentais na Constituição Federal de 1988. 8 ed. Porto Alegre: Livraria do Advogado, 2010, p. 37-38. Também ressaltando o aspecto de que o homem não é instrumento, mas sim o próprio fim, cf. BRANCO, 2007, p. 55.

COMPARATO aduz que a dignidade da pessoa vai além, "ela resulta também do fato de que, pela sua vontade racional, só a pessoa vive em condições de autonomia, isto é, como ser capaz de guiar-se pelas leis que ele próprio edita." (2013, p. 34).

${ }^{240}$ SARLET, 2010, p. 49. 
Isso não significa que se deva abrir mão de buscar uma noção conceitual (ainda que mínima) do princípio da dignidade da pessoa, de modo a garantir-lhe o conteúdo e eficácia $^{241}$. Segundo a definição proposta por SARLET, a dignidade da pessoa é

a qualidade intrínseca e distintiva reconhecida em cada ser humano que o faz merecedor do mesmo respeito e consideração por parte do Estado e da comunidade, implicando, neste sentido, um complexo de direitos e deveres fundamentais que assegurem a pessoa tanto contra todo e qualquer ato de cunho degradante e desumano, como venham a lhe garantir as condições existenciais mínimas para uma vida saudável, além de propiciar e promover sua participação ativa e co-responsável nos destinos da própria existência e da vida em comunhão com os demais seres humanos, mediante o devido respeito aos demais seres que integram a rede da vida. ${ }^{242}$

Como se vê da definição proposta, essa "qualidade intrínseca e distintiva" de cada pessoa implica "um complexo de direitos e deveres fundamentais" que a assegurem "contra todo e qualquer ato de cunho degradante e desumano". Pode-se aí vislumbrar a força normativa do princípio da dignidade da pessoa, o qual fica dotado de eficácia jurídica plena $^{243}$.

Sim, porque ainda que se considerem os direitos fundamentais catalogados no rol constitucional como desdobramentos e concreções da noção de dignidade da pessoa, fazendo com que eles sejam redutíveis a ela, não se pode absorver uma teoria de interpretação da constituição que retire a eficácia própria do princípio da dignidade da pessoa. Esse princípio tem, por si, força jurídica e eficácia plena, independentemente da vigência dos demais direitos fundamentais constantes do rol da Constituição Federal.

${ }^{241}$ Para Ingo SARLET, no mesmo sentido da preocupação que foi exposta acerca do conteúdo jurídico do princípio, a renúncia à busca de fundamentação e legitimação da noção de dignidade da pessoa humana “pode de fato resultar em uma aplicação arbitrária e voluntarista da noção de dignidade”. (2010, p. 49).

${ }^{242}$ SARLET, 2010, p. 70.

243 A dignidade da pessoa também "há de inspirar todas as atividades hermenêuticas" (BRANCO, 2007, p. 58). Para ROMITA, "A dignidade da pessoa humana atua como fundamento do princípio estruturante do Estado Democrático de Direito e, em consequência, impregna a totalidade da ordem jurídica, espraia-se por todos os ramos do direito positivo e inspira não só a atividade legislativa, como também a atuação do Poder Judiciário." (2012, p. 277). 
Pois bem. A questão a enfrentar agora é a de saber em que medida o assédio moral representa uma violação à dignidade da pessoa.

A prática do assédio moral afronta a dignidade da vítima no sentido de que tende a lhe retirar a possibilidade de se postar existencialmente como pessoa autônoma e consciente de seu papel na coletividade (mesmo considerado o microcosmo da empresa em que ela trabalha ou o departamento onde é lotada).

A vítima do assédio moral perde a autoconfiança e, também, vê o desmoronamento de sua vida profissional, pessoal e familiar. Esses caracteres são referidos de forma contundente pela doutrina especializada. É, na perspectiva da vítima, uma total perda de sentido ${ }^{244}$. Nesse contexto, sua dignidade é violentada, pois a vítima é feita instrumento do poder do agressor, seja este um colega narcisista perverso ou mesmo o sistema da empresa, no caso do assédio organizacional.

O trabalhador deixa de ser pessoa, e passa a ser visto apenas como "recurso humano", como uma força de trabalho que deve ser mais e mais explorada, em favor do aumento do lucro da empresa ${ }^{245}$. Quando muito, ele passa a ser o instrumento de manutenção das relações autoritárias de trabalho, nas mãos de um chefe perverso.

Constata-se aí a agressão direta à dignidade da pessoa ${ }^{246}$. É a negação da máxima de Kant, de que "o homem existe como fim em si mesmo". É o tratamento do homem como meio, como ferramenta, como mercadoria ${ }^{247}$.

\footnotetext{
244 "Quando o processo de assédio se estabelece, a vítima é estigmatizada: dizem que é de difícil convivência, que tem mau caráter, ou então que é louca. Atribui-se à sua personalidade algo que é consequiência do conflito e esquece-se o que ela era antes, ou o que ela é em um outro contexto. Pressionada ao auge, não é raro que ela se torne aquilo que querem fazer dela." (HIRIGOYEN, 2009a, p. 69).

${ }^{245}$ Como ressalta COMPARATO, "enquanto o capital é, por assim dizer, personificado e elevado à dignidade de sujeito de direito, o trabalhador é aviltado à condição de mercadoria, de mero insumo no processo de produção, para ser ultimamente, na fase de fastígio do capitalismo financeiro, dispensado e relegado ao lixo social como objeto descartável" (2013, p. 36).

${ }^{246}$ Sem olvidar, evidentemente, que "a saúde do trabalhador, como espécie do gênero, compõe, ineludivelmente, o chamado conteúdo essencial da dignidade da pessoa humana, não podendo, jamais, ser postergada sua preservação" (SILVA, J. A., 2008, p. 78).

${ }^{247}$ Recorde-se do já referido art. 427 do Tratado de Versalhes, que veda o tratamento do trabalho como mercadoria; cf. também SOUTO MAIOR, 2011, p. 250 et seq.
} 
Inevitável, a esta altura, o seguinte questionamento: é mesmo necessária essa construção teórica de afronta da dignidade da pessoa pela prática do assédio moral? Não existem inúmeros direitos fundamentais catalogados que são passiveis de violação específica nos casos de assédio moral (honra, intimidade, integridade física ou psíquica)? Essa constatação não parece tornar indevida a remissão direta ao princípio da dignidade humana, em matéria de assédio moral?

O questionamento é válido. Em especial diante da tendência doutrinária de resguardar o princípio da dignidade da pessoa, no sentido de que ele seja acionado apenas nas situações mais graves de supressão da própria condição humana, de modo a evitar o indesejável "desgaste" do princípio, decorrente de sua transformação em lugar-comum retórico.

Não se pode, de fato, menosprezar a importância desse cuidado. O princípio da dignidade da pessoa é carregado de conteúdo ético e foi erigido, no Brasil, a valor fundamental da República, na Constituição Federal de 1988 (art. 1º, inciso III). Dele decorrem inúmeras consequências jurídico-constitucionais e cargas de eficácia de outras normas de direito constitucional e infraconstitucional, as quais são por sua vez dotadas de vigência própria, e eficácia mais densa, por se referirem a situações mais específicas.

Nesse contexto pode ser retomado o exemplo do direito fundamental à limitação da jornada de trabalho (CF, art. $\left.7^{\circ}, \mathrm{XIII}\right)$. Parece difícil contestar a afirmação de que esse direito tem seu fundamento no princípio da dignidade da pessoa - o direito à limitação do tempo de trabalho em favor do empregador evita que o empregado se torne algo como um maquinário a serviço da produção, e põe em relevo as necessidades humanas básicas da existência extralaboral: o convívio familiar e social, o lazer, a educação, entre outros.

Contudo, embora seja importante não perder de vista a relação entre o direito fundamental à limitação de jornada e o princípio da dignidade da pessoa, é desnecessário formular discussões específicas sobre essa relação a cada ação judicial que tenha por objeto o pagamento de horas extras. O direito fundamental catalogado no art. $7^{\circ}$ da $\mathrm{CF}$ e a legislação ordinária pertinente ao tema são mais do que suficientes para a tutela 
jurisdicional devida na hipótese. O que é pertinente e necessário é que se faça a interpretação dessas normas à luz do valor fundamental da dignidade da pessoa.

Por sua vez, o assédio moral é diferente, nesse aspecto. Como se viu em tópicos anteriores, o assédio moral ainda não tem sua conceituação bem definida no Brasil, senão por diplomas legais mais voltados à área administrativa de alguns Estados e Municípios. Para o trabalhador em geral, nas relações de emprego regidas pela Consolidação das Leis do Trabalho, o assédio moral ainda é uma figura de noção fugidia e nebulosa, a despeito da evidente gravidade atestada pela produção científica recente.

Quanto ao assédio moral, portanto, é mais do que conveniente evidenciar, à falta de um regime legal específico e suficiente, sua relação direta com o princípio da dignidade da pessoa.

Ademais, a abordagem da prevenção também recai no mesmo princípio. A tutela inibitória no processo do trabalho é de aplicação prática bastante incipiente no Brasil, e particularmente nos casos de assédio moral o aparato procedimental é um tanto confuso. É razoável esperar, nesse contexto, que o Judiciário seja levado a uma discussão que envolva a ponderação entre direitos para avaliar o cabimento de uma ordem inibitória específica de assédio moral. E, nessa ponderação, é plausível que sejam alegados pelo empregador direitos como o de propriedade e a própria segurança jurídica ${ }^{248}$.

É por todos esses motivos que se justifica a remissão direta da situação à violação do princípio da dignidade da pessoa. A despeito da validade do questionamento, então, existe uma razão plausível para a construção que se vem de defender: justamente a necessidade de uma nova postura do processo e do juiz do trabalho nos casos de assédio moral, em especial no que toca à sua prevenção.

A ideia do manejo da tutela preventiva, com a consequente invasão da esfera jurídica do réu antes mesmo da produção de qualquer dano, em nossa ordem processual, enseja naturalmente inúmeros conflitos de bens a tutelar. Nesse contexto, é importante que

${ }^{248}$ Veja-se que a segurança jurídica foi o princípio usado de forma recorrente por PEDUZZI, para criticar a aplicação axiológica da dignidade da pessoa $(2009$, p. 56$)$; tal questão foi salientada neste mesmo tópico, anteriormente. 
fique claro que um desses bens submetidos à ponderação é a dignidade humana do trabalhador. Pois, nesse panorama, haverá a imposição de um ônus argumentativo ${ }^{249}$ maior para que o juiz da causa negue a proteção eficaz que a vítima procura obter pelo processo.

Em atenção à máxima clareza: não se está a defender que a ação que visa à tutela inibitória de assédio moral deva necessariamente ser resolvida com base em ponderação de direitos, nem se pretende catalogar a priori quais seriam os direitos envolvidos. A proposta é apenas firmar o entendimento de que, nesses processos, a lide abrange diretamente o conteúdo jurídico da dignidade da pessoa ${ }^{250}$. Com isso, sendo o caso de ponderar no caso concreto os direitos em colisão, é fundamental não ter dúvidas da presença da dignidade humana nessa análise.

\subsection{Consequências do assédio moral.}

A proposta deste tópico é demonstrar as consequências e prejuízos decorrentes da prática do assédio moral no meio ambiente do trabalho. O que se verifica das pesquisas sobre o assunto é que, embora as vítimas evidentemente sofram as piores e mais graves consequências do assédio, também as empresas são prejudicadas em seus interesses ${ }^{251}$ e, em um contexto mais amplo, a coletividade arca com parte dos prejuízos.

\footnotetext{
249 Sobre a tese do ônus argumentativo amplo para a restrição a conteúdos de direitos fundamentais, vide SILVA, V. A., 2010, em especial p. 40-41.

${ }^{250}$ Embora não sejam desconhecidas construções em que a dignidade da pessoa é sopesada e relativizada em favor da proteção plena da propriedade do empregador. SOUTO MAIOR assevera: "por exemplo, jurisprudência e doutrina têm concluído que a proteção da propriedade, por parte do empregador, justifica que este submeta seus empregados a procedimentos de revista íntima, desde que se o faça com respeito à dignidade humana. $\mathrm{O}$ esvaziamento da expressão 'respeito à dignidade humana' funciona aí justamente para que, na prática, a dignidade humana seja desrespeitada", porque "ao se firmar que a proteção da propriedade legitima uma certa 'flexibilidade' da proteção do ser humano estabelece-se o pressuposto de que a proteção do ser humano está em segundo plano em relação à propriedade" (2005, p. 210-211). VIANA entende que a revista pessoal somente seria lícita quando indispensável e, ainda assim, autorizada em negociação coletiva (1996, p. 233). Por outro lado, Estêvão MALLET reputa ilícita a revista que se qualifique como íntima, mas “outras formas de revista ou de inspeção, que não tenham caráter íntimo, encontram amparo no poder diretivo do empregador e não violam o dever de boa fé contratual. Não estão, portanto, peremptoriamente afastadas" (Direitos da personalidade e direito do trabalho. Revista do TRT 7ª Região, Fortaleza, ano 30, n. 30, jan/dez 2007, p. 142).

${ }^{251}$ Embora a tônica da presente dissertação não sejam os interesses empresariais, e sim a proteção efetiva à dignidade e aos direitos fundamentais dos trabalhadores, não se pode ignorar a advertência de HIRIGOYEN, segundo quem "para convencer donos de empresa muito pragmáticos, é preciso privilegiar os argumentos
} 
A prevenção do assédio moral está ligada, portanto, a uma questão de interesse público. Sobre essa ideia não pode haver dúvida.

Conforme já exposto anteriormente ${ }^{252}$, o assédio moral é uma violação direta à dignidade da pessoa. Somente por essa razão, a gravidade da conduta já pode ser compreendida. Mas não é só isso. As consequências físicas e psicológicas para a vítima são arrasadoras.

HIRIGOYEN assinala que

Todas as vítimas, com raríssimas exceções, experimentam uma desestabilização permanente. Em todas as outras formas de sofrimento no trabalho e, em particular, no caso de uma pressão profissional excessivamente forte, quando cessa o estímulo, cessa também o sofrimento, e a pessoa consegue recuperar o estado normal. $\mathrm{O}$ assédio moral, ao contrário, deixa seqüelas marcantes que podem evoluir do estresse pós-traumático até uma sensação de vergonha recorrente ou mesmo modificações duradouras de personalidade. ${ }^{253}$

A mesma autora reforça:

Quando existe um grande investimento afetivo no trabalho, em caso de afastamento ou exclusão ocorre o que, em nosso jargão, chamamos de desmoronamento pessoal. ${ }^{254}$

Com efeito, o trabalho é um aspecto muito relevante da vida da maioria das pessoas. É um meio de sobrevivência e de ascensão social, sem dúvida, mas sua importância não se resume a esses fatores. Pelo trabalho a pessoa exterioriza valores de sua personalidade, de sua existência; a modificação do mundo real pelo trabalho humano é um objeto cultural de grande valor intrínseco. Muitas vezes, é isso que dá sentido à vida da

racionais e avaliados estatisticamente, mais do que os elementos humanos e éticos. É preciso mostrar-lhes que o assédio moral custa muito e que as estratégias de prevenção são um bom investimento." (2009b, p. 321).

${ }^{252}$ Vide tópico 4.4, supra.

${ }^{253}$ Ibidem, p. 164.

${ }^{254}$ Ibidem, p. 233. 
pessoa - gerando mesmo uma confusão entre as ideias de "trabalhar para viver" e "viver para trabalhar" 255 .

Apontam no mesmo sentido as conclusões extraídas por Margarida BARRETO de sua pesquisa de campo sobre o problema do assédio moral trabalhista. A autora relata:

Constatei que viver, para os trabalhadores e as trabalhadoras, significa proporcionar melhores condições de vida a seus filhos, garantir a sobrevivência da família, trabalhar, enfim. É comum os trabalhadores se referirem ao trabalho como o 'tudo em sua vida', mostrando sua dependência a esse respeito. Tudo que os impeça de trabalhar será sempre assustador. Dessa forma, adoecer adquire para eles uma dimensão de sofrimento que vai além do biológico e não pode ter lugar no seu cotidiano. $^{256}$

E ainda:

A identificação do trabalho com a própria vida desvela uma dimensão vivida por homens e mulheres que o mostra como produtor não somente de mercadorias, mas do próprio homem. É naquilo que produz que ele coloca sua vida, sua alegria e a potência de ação. ${ }^{257}$

O assédio moral representa, então, uma potencial ofensa ao direito ao trabalho, pois pode excluir a pessoa de seu emprego e, mais que isso, pode minar a capacidade laborativa da vítima. Consequentemente, ao impedir o exercício desse direito, o assédio moral assume a feição de ofensa ao direito à vida. Daí a compreensão de que o assédio moral viola diretamente a personalidade do trabalhador e tem a possibilidade de concretizar um verdadeiro atentado à sua vida ${ }^{258}$.

\footnotetext{
${ }^{255}$ Carlos Eduardo Carrusca VIEIRA salienta, da perspectiva da psicologia, que "[na] condição de uma atividade útil e socialmente valorizada, que não encontra equivalência em outras atividades da vida, o trabalho é objeto de investimento afetivo capaz de portar uma significação narcísica estreitamente relacionada à estima que o indivíduo faz de si mesmo, situada também no interjogo das mediações com os pares. [...] O trabalho constitui-se como uma atividade que, para além de suas dimensões fisiológicas e cognitivas, implica pessoalmente o trabalhador e coloca-o frente a outrem, comportando assim dimensões sociais e éticas." (Assédio: do moral ao psicossocial. Curitiba: Juruá, 2008, p. 141). Cf. também TURTE, 2011, p. 19.

${ }^{256}$ BARRETO, Margarida. Violência, saúde e trabalho: uma jornada de humilhações. São Paulo: EDUC, 2006, p. 35, grifo do original.

${ }^{257}$ BARRETO, 2006, p. 129.

${ }^{258}$ TURTE, 2011, p. 61.
} 
É nesse contexto que a expressão usada por HIRIGOYEN, citada acima, assume uma carga de significação extremamente forte. $\mathrm{O}$ "desmoronamento pessoal" do trabalhador por causa do assédio moral deve ser compreendido à luz do princípio da dignidade da pessoa, como verdadeira tentativa de supressão de sua condição humana: uma aniquilação $^{259}$.

Nesse sentido, GUEDES relata que

Heinz Leymann juntamente com outros psicoterapeutas encontraram grandes semelhanças entre o dano produzido por assédio moral desordem pós-traumática por estresse (DTS) e aquele observado nas vítimas de prisões, campos de concentração e extermínio nazistas. ${ }^{260}$

A mesma autora enuncia as seguintes consequências da prática de assédio

moral:

Os efeitos nefastos para o organismo submetido ao assédio moral no trabalho não se limitam ao aspecto psíquico, mas atingem o corpo físico, fazendo com que todo o organismo se ressinta das agressões. Os distúrbios podem recair sobre o aparelho digestivo, ocasionando bulimia, problemas gástricos diversos e úlcera. [...]

Os danos na esfera emocional atingem em cheio a vida familiar e social da vítima, desencadeando crise existencial, crise de relacionamento e crise econômica. [...]

A crise de relacionamento social é corolário dessa situação de crise existencial: a vítima se torna amarga, lamurienta e desagradável. [...]

Não são raros os relatos das vítimas afirmando que depois do sofrimento passaram a compreender os motivos que podem levar uma pessoa a matar outra. ${ }^{261}$

Por outro lado, conforme já salientado, os colegas próximos da vítima, ainda que não sofram diretamente os efeitos da conduta hostil do agressor, sofrem os efeitos

\footnotetext{
259 "O rebaixamento de função ou a mortificante inatividade, a derrisão, o assédio sexual, as sanções disciplinares injustas, a revista reiterada, a vigilância abusiva, a sujeição humilhante e discriminatória, a solidão proveniente da segregação e do isolamento físico ou decorrente do comportamento indiferente ou de franca rejeição dos colegas, ferem a espontaneidade do indivíduo e atingem a esperança e a alegria de viver, provocando a depressão e o desgaste psicofísico." (GUEDES, 2008, p. 128).

${ }^{260}$ GUEDES, ibidem, p. 54-55.

${ }^{261}$ GUEDES, 2008, p. 108.
} 
dessa conduta na poluição do meio ambiente do trabalho, pois esse ambiente fica dominado pelo medo ${ }^{262}$.

GUEDES reforça que

o terror psicológico no trabalho atinge direitos e interesses de todos os trabalhadores envolvidos na organização em que o sujeito perverso atua. Seguramente numa situação de assédio moral no trabalho, existem interesses transindividuais em jogo, [uma vez que] a ação do sujeito perverso pode saturar o ambiente de trabalho a ponto de todas as pessoas que ali trabalhem sentirem os efeitos nocivos da violência. ${ }^{263}$

Enfim, a prática do assédio moral tem uma ampla incidência coletiva no meio ambiente do trabalho. Não se trata de mero atrito entre duas pessoas, com reflexos meramente individuais. $\mathrm{O}$ interesse coletivo dos trabalhadores direta ou indiretamente envolvidos deve ser colocado em primazia - e atrai a atenção do processo no sentido de conferir a tutela jurisdicional mais adequada à proteção desse interesse.

Finalmente, não se devem ignorar os custos sociais do assédio moral, decorrentes de absenteísmo das vítimas, aposentadorias e tratamentos de saúde 264265.

Têm contribuído muito nesses índices, como já mencionado anteriormente, as chamadas doenças psíquicas, muitas delas ligadas ao trabalho. THOME refere nesse sentido uma transformação do "perfil ideológico das doenças tradicionais do trabalho, com

\footnotetext{
262 "O medo gera condutas de obediência, ou mesmo de submissão, por parte da pessoa visada, mas também por parte dos colegas que deixam que tal aconteça, que não querem ver o que se passa em torno deles. É o que se dá no atual reinado do individualismo, do “cada um por si”" (HIRIGOYEN, 2009a, p. 87).

${ }^{263}$ GUEDES, ibidem, p. 126.

264 "O Estado paga um alto custo tanto no que diz respeito à saúde pública, quanto no que concerne a aposentadorias precoces." (GUEDES, ibidem, p. 110). "O assédio moral afeta também os custos operacionais da empresa, com a baixa produtividade daí advinda, absenteísmo, falta de motivação e de concentração que aumentam os erros no serviço." (BARROS, Alice Monteiro de. A proteção jurídica à intimidade do empregado. 2 ed. São Paulo: LTr, 2009).

265 Entretanto, o argumento de natureza econômica, tendente a salientar os custos sociais dos prejuízos à saúde dos trabalhadores, deve ser encarado meramente como argumento de reforço. Em verdade, o direito à saúde é direito fundamental, e não se pode medir ou ponderar com análises econômicas de custos. Nesse sentido: "O trabalho não deve expropriar do homem seu vigor físico ou mental, mesmo que isso represente crescimento econômico não somente para o empresário, mas para a nação como um todo. A higidez do trabalhador é um direito fundamental e se impõe aos interesses do capitalismo, sejam estes quais forem." (DINIZ, 2003, p. 42).
} 
o acréscimo de um número muito alto de doenças psíquicas diante do sofrimento mental causado aos trabalhadores"266.

Mesmo uma rápida e superficial observação prática de ações trabalhistas em trâmite atualmente autoriza a conclusão de que as doenças psíquicas são cada vez mais comuns em trabalhadores de diversos ramos profissionais.

Sebastião Geraldo de OLIVEIRA menciona a Estratégia Comunitária da União Europeia para a saúde e segurança no trabalho (2007-2012), a qual referia expressamente que

\begin{abstract}
Atualmente, os problemas associados a uma má saúde mental constituem a quarta causa mais frequente de incapacidade para o trabalho. A OMS calcula que, até 2020, a depressão venha a tornar-se a principal causa de incapacidade. O local de trabalho pode ser um espaço privilegiado para prevenir problemas psicológicos e promover uma melhor saúde mental. ${ }^{267}$
\end{abstract}

Tudo, como se vê, a indicar que a saúde mental dos trabalhadores está precária. A situação demanda providências concretas de prevenção.

Entre as patologias psíquicas mais graves, nesse quadro de alarmante incidência nos dias atuais, está a chamada síndrome de burnout. Tal enfermidade consiste no esgotamento mental do trabalhador por situação de estresse prolongado ${ }^{268}$, isto é, o estresse prolongado leva a uma situação de exaustão, de fadiga extrema ${ }^{269}$.

${ }^{266}$ THOME, 2009, p. 91.

${ }^{267}$ OLIVEIRA, Sebastião Geraldo de. Proteção jurídica à saúde do trabalhador. 6 ed. São Paulo: LTr, 2011, p. 211.

268 "O significado do termo stress pode ser entendido com o processo de tensão diante de uma situação de desafio por ameaça ou conquista." (CATALDI, 2011, p. 44).

269 “A síndrome do burnout surge em decorrência do estresse cronificado, da tensão permanente, que acaba provocando algo semelhante a um 'incêndio interno' ou queima total das energias para o trabalho, como sugere o termo em inglês.” (OLIVEIRA, S. G., 2011, p. 225-226). Segundo CATALDI (2011, p. 46-48), existem três aspectos básicos da doença: a) exaustão emocional; b) despersonalização e distanciamento do trabalhador; c) redução das realizações pessoais e profissionais. A autora também enfatiza que "[a] síndrome de burnout não aparece repentinamente como resposta a um estressor determinado. [...] O quadro de burnout vai instalando-se insidiosamente [...]" (ibidem, p. 48). 
O assédio moral leva a situações de estresse prolongado, tanto na vítima direta quanto nos trabalhadores que partilham o mesmo meio ambiente do trabalho e, como visto, sofrem as consequências da poluição psicológica decorrente da conduta do assediador ${ }^{270}$. Assim, é preciso pôr em destaque o assédio moral no trabalho como uma das causas da síndrome de burnout ${ }^{271}$.

Quanto ao caráter ocupacional da síndrome de burnout, ele não representa novidade alguma. O Regulamento da Previdência Social (Decreto 3.048/1999) prevê expressamente, em seu Anexo II, lista "B”, a síndrome de burnout (também denominada "síndrome de esgotamento profissional") ligada a fatores ocupacionais, como o trabalho penoso e as "dificuldades físicas e mentais" no trabalho ${ }^{272}$. A subsunção da prática de assédio moral a essas previsões é evidente.

Diante do que foi exposto, fica evidente que não se pode mais abordar o assédio moral como problema individual, como problema de relacionamento entre pessoas com características divergentes. O problema do assédio moral tem natureza coletiva e, quanto às consequências previdenciárias, afeta inclusive interesses públicos secundários ${ }^{273}$. O tema da prevenção do assédio moral deve assumir preponderância sobre a reparação dos danos causados, em virtude da natureza dos bens jurídicos afetados pela violência psicológica.

\footnotetext{
${ }^{270}$ SILVA, J. A., 2008, p. 166.

271 "Diante da análise das principais causas do surgimento da síndrome de burnout, fica claro que os atos que configuram assédio moral no trabalho geram insatisfação, ansiedade e desespero, criando condições profícuas para a configuração do burnout." (THOME, 2009, p. 97). No mesmo sentido: DALLEGRAVE NETO, 2008, p. 212.

${ }^{272}$ A lista de doenças do Regulamento da Previdência Social tem, e não poderia ser diferente, caráter exemplificativo e não exaustivo. Vide, nesse sentido: TEIXEIRA, Sueli. A depressão no meio ambiente do trabalho e sua caracterização como doença do trabalho. Revista do Tribunal Regional do Trabalho da $\mathbf{3}^{\mathbf{a}}$ Região, v. 46, n. 76. Belo Horizonte: julho/dezembro 2007, p. 36-37.
}

${ }^{273}$ ALKIMIN, 2009, p. 87-88. 


\subsection{Assédio moral e dano moral}

Não seria conveniente encerrar este capítulo sem algumas considerações sobre o dano moral decorrente do assédio moral trabalhista e sua compensação.

O dano moral $^{274}$ é hoje a face mais visível do assédio moral e de suas consequências. E não é difícil entender a razão desse fato: em geral, os processos dizem respeito a situações pretéritas, envolvendo trabalhador que já deixou o emprego e pretende ressarcimento de danos alegadamente causados pela conduta do ex-empregador. É justamente em face desse cenário que a presente pesquisa voltou-se para a valorização da prevenção; isto é, para o sentido de evitar o dano.

É tamanha a relação entre dano moral e assédio moral na prática forense que, não raro, ocorre verdadeira confusão entre as denominações. Com frequência a petição inicial requer uma compensação em razão de assédio moral, e narra um episódio delimitado no tempo e no espaço, no qual o autor da ação teria sido ofendido por um superior hierárquico $^{275}$.

Aliás, convém ressaltar a impropriedade científica da própria expressão dano moral, conforme a lição de Paulo Eduardo Vieira de OLIVEIRA. Para o autor, a denominação mais correta seria dano pessoal, por abranger todos os aspectos da personalidade que são atingidos pela conduta do agressor ${ }^{276}$. Nesta dissertação, todavia, não obstante a procedência da crítica mencionada, optou-se pelo uso da expressão dano

\footnotetext{
${ }^{274}$ Assumindo-se que, "no momento atual, doutrina e jurisprudência dominantes têm como adquirido que o dano moral é aquele que, independentemente de prejuízo material, fere direitos personalíssimos, isto é, todo e qualquer atributo que individualiza cada pessoa, tal como a liberdade, a honra, a atividade profissional, a reputação, as manifestações culturais e intelectuais, entre outros." (MORAES, M. C. B., 2003, p. 157). Sobre as notas conceituais do instituto, cf. também SANTOS, E. R., 2009, p. 55-57; e PAMPLONA FILHO, 2002, p. 52-53.

${ }^{275}$ Como foi exposto anteriormente, esse ato não tipifica o assédio moral no ambiente de trabalho. Vide a respeito o tópico 4.2.2, supra.

276 “ $O$ termo tecnicamente correto, porque melhor exprime o conceito jurídico do instituto, é dano pessoal ou dano à personalidade, tomado o termo pessoa em toda sua ampla dimensão, compreendendo a integridade psicofísica, a intelectual, a afetiva, a moral e a social." (OLIVEIRA, P. E. V. O dano pessoal no direito do trabalho. 2 ed. São Paulo: LTr, 2010, p. 40).
} 
moral, não por outro motivo senão a consagração da denominação pelo uso generalizado na comunidade jurídica ${ }^{277}$.

O fato que se pretende pôr em relevo é que, na maioria das vezes, é por meio dos pedidos de compensação por dano moral que o Poder Judiciário tem contato com as práticas de assédio moral no meio ambiente do trabalho. O desafio que se apresenta, portanto, é o de sair da rotina de avaliar situações pretéritas e danos consumados, para passar a atuar na prevenção dos danos, na prevenção do assédio moral no trabalho.

A própria compensação do dano moral é um paliativo que não serve de medida corretiva, sequer do ponto de vista da vítima que teve seu pedido atendido no processo. É pacífico em doutrina que o valor em dinheiro não repara o dano moral sofrido pela vítima, até porque o bem jurídico afetado não é passível de reconstrução ou de reparação ${ }^{278}$. Tem-se na compensação em dinheiro uma medida de satisfação à vítima, que por um lado poderá usar essa quantia na busca de prazeres que favoreçam o esquecimento da dor causada pelo dano moral ${ }^{279}$; e que, por outro lado, terá a visão de que o sofrimento que lhe foi causado gerou uma resposta ao agressor - a punição do agressor ${ }^{280}$, por si só, acarreta uma satisfação pessoal à vítima.

De outro lado, apesar da insuficiência das compensações por dano moral para a proteção efetiva aos bens jurídicos da personalidade, existem aspectos positivos que

277 Yussef CAHALI enfatiza que "é possível distinguir, no âmbito dos danos, a categoria dos danos patrimoniais, de um lado, dos danos extrapatrimoniais, ou morais, de outro" (CAHALI, Yussef Said. Dano moral. 3 ed. São Paulo: RT, 2005, p. 20-21).

${ }^{278}$ Com efeito, “a sanção do dano moral não se resolve numa indenização propriamente, já que indenização significa eliminação do prejuízo e das suas conseqüências, o que não é possível quando se trata de dano extrapatrimonial; a sua reparação se faz através de uma compensação, e não de um ressarcimento; impondo ao ofensor a obrigação de um pagamento de uma certa quantia em dinheiro em favor do ofendido, ao mesmo que agrava o patrimônio daquele, proporciona a este uma reparação satisfativa" (CAHALI, 2005, p. 44).

Para Valdir FLORINDO, “A indenização por dano moral não significa o pretium doloris (preço da dor), porque essa verdadeiramente nenhum dinheiro paga" (Dano moral e o direito do trabalho. 4 ed. São Paulo: LTr, 2002, p. 280).

"Aquele que sofre um dano moral deve ter direito a uma satisfação de cunho compensatório. Diz-se compensação, pois o dano moral não é propriamente indenizável; 'indenizar' é palavra que provém do latim, 'in dene', que significa devolver (o patrimônio) ao estado anterior, ou seja, eliminar o prejuízo e suas conseqüências - o que, evidentemente, não é possivel no caso de uma lesão de ordem extrapatrimonial." (MORAES, M. C. B., 2003, p. 145).

${ }^{279}$ FLORINDO, 2002, p. 281.

${ }^{280}$ SANTOS, E. R., 2009, p. 74. 
também merecem apresentação. Em primeiro lugar, e tendo em vista até mesmo a imensa variedade de temas que vêm sendo suscitados nos processos trabalhistas, a jurisprudência assume um posto de vital importância ao suprir a lacuna legislativa na definição do que gera e do que não gera danos à personalidade do empregado. Trata-se de um efeito conexo das decisões judiciais sobre comportamentos futuros.

A partir do momento em que se consolida a jurisprudência, por exemplo, no sentido de que algumas dinâmicas de grupo, nas quais alguns empregados são expostos a situações constrangedoras, acarretam danos à personalidade e dever de indenizar ${ }^{281}$, as empresas passam a ter outro parâmetro de avaliação da própria organização. As estratégias empresariais são muitas vezes revistas com base nesses precedentes.

Além disso, existe um fator preventivo secundário, por assim dizer, que reside no arbitramento das compensações por dano moral, mesmo no bojo de processos individuais. A condenação de um empregador por determinada conduta que se repute ofensiva da personalidade do trabalhador deve acarretar, imediatamente, a cessação desse comportamento eventualmente praticado em face de outros empregados da empresa. Significa, na visão do empresário, uma verdadeira "redução de passivo", pois se a um dos trabalhadores foi deferida compensação por aquele ato, espera-se que os demais também sejam potenciais litigantes, com grande probabilidade de verem atendidos seus pedidos pelo Judiciário. Seria a multiplicação das compensações, em prejuízo ao patrimônio e à imagem do empregador.

Daí a proposição doutrinária de que o arbitramento da compensação por dano moral deve levar em consideração, entre outros critérios, o desestímulo ao ofensor ${ }^{282}$. A condenação deve servir-lhe de forte motivo para não reincidir na conduta ilícita. Essa não

\footnotetext{
${ }^{281}$ Nesse sentido a decisão do Tribunal Superior do Trabalho no Recurso de Revista 78100-90-2006-5-040011, Rel. Min. Renato de Lacerda Paiva, DJ 3.4.2013.

${ }^{282}$ Nesse sentido: OLIVEIRA, P. E. V., 2010, p. 72-73; FELICIANO, 2005, p. 15.

"Embora o escopo fundamental da responsabilidade civil seja a reparação do dano sofrido pelo lesado, e não a punição do lesante, há de que se ter presente que, na problemática do dano moral, além dessa finalidade principal, compensatória, como forma de reparar a dor do lesado, também existe uma finalidade punitiva; além disso, a indenização do dano moral exerce uma função admonitória, valendo como advertência para que o ofensor não venha a reincidir na prática de atos atentatórios aos direitos de personalidade de outrem" (CAHALI, 2005, p. 562).
} 
deixa de ser uma atuação preventiva já adotada pelo Judiciário, ainda que na perspectiva individual $^{283}$.

Aliás, com o intuito de potencializar esse efeito preventivo das compensações financeiras, em alguns casos o Judiciário tem arbitrado uma compensação por dano social, além da compensação individual do autor da ação, em especial quando o poder econômico do ofensor recomenda majoração da condenação em patamar acima do que seria razoável deferir a apenas uma vítima ${ }^{284}$.

Não deve haver dúvidas, contudo, acerca da insuficiência desses efeitos preventivos das ações individuais que tratam de assédio moral e de dano moral. A prevenção necessária no âmbito do assédio moral é uma providência concreta e real, com eficácia na proteção à personalidade dos trabalhadores, antes que um deles venha a propor sua pretensão de ressarcimento por danos que nunca poderão ser remediados verdadeiramente.

${ }^{283}$ Tal é o escopo da compensação do dano moral: "De um lado, deve, como qualquer ressarcimento, compensar a vítima através da indenização pelos danos (rectius, dores) sofridos. É a chamada função compensatória. De outro lado, ao se propor que as condições econômicas das partes sejam consideradas, assim como o grau de culpa do ofensor, é estabelecida uma outra causa de ressarcimento, desta vez visando punir o ofensor [...]. É a chamada função punitiva, que alguns chamam de função preventiva, pedagógica ou exemplar." (MORAES, M. C. B., 2003, p. 31-32).

${ }^{284}$ Algumas indenizações pela prática de dano social têm sido impostas em sentenças proferidas por juizes de primeiro grau de jurisdição, mas, no mais das vezes, são reformadas em grau recursal. Entretanto, é possível perceber um lento e tímido avanço da jurisprudência no sentido da manutenção dessas condenações. Um exemplo é a seguinte decisão recentemente proferida pelo Tribunal Regional do Trabalho da $4^{\mathrm{a}}$ Região em sede de recurso ordinário (grifos nossos):

"Portanto, demonstrado nestes autos que as demandadas têm praticado, de forma deliberada, desrespeito à ordem jurídica trabalhista, o que tem culminado com número significativo de ações nesta Justiça Especializada, devendo o julgador proferir condenação que objetive a reparação específica pertinente ao dano social perpetrado, ainda que fixada de ofício pelo titular da sentença, para proteção da coletividade e da ordem jurídica, em virtude de seu compromisso ético com a proteção da dignidade da pessoa humana e do trabalho. Nessa senda, não há falar em julgamento "extra petita", não comportando reforma a sentença, por esse prisma, muito menos violação aos arts. 128 e 460, do CPC, já que, ainda que não tenha havido requerimento de indenização por dano social, incumbe ao Julgador, ex officio, ao constatar que o empregador esteja infringindo reiteradamente direitos trabalhistas, adotar medidas que inibam tal conduta e comportamento. Com relação ao valor fixado e o destino a ser dado ao montante, entendo que está dentro de parâmetros razoáveis e proporcionais aos atos que vem sendo praticados pelas rés, sendo irrelevante a elas que a importância da indenização seja utilizada para pagamento de demandas arquivadas na Unidade Judiciária. Ou seja, a pena pecuniária aplicada às reclamadas é decorrente de dano social, nada sendo mais justo do que utilizar o valor da indenização para pagamento de dívidas pendentes, oriundas de processos não findos, atingindo, de certo modo, o fim social da indenização imputada. Nesse contexto, por entender justa a medida adotada pelo julgador de primeiro grau, mantenho a sentença por seus próprios fundamentos, inexistindo ofensa/violação a qualquer dos dispositivos legais invocados pelas reclamadas. Provimento negado. (RO 0000983-94-2012-5-04-0663, originário da $3^{\text {a }}$ VT de Passo Fundo/RS, Rel. Des. Maria Madalena Telesca, DJ 20.11.2013). 
Essa providência concreta e real pode ser obtida por meio da tutela inibitória, cujo regime jurídico será analisado no capítulo seguinte. 


\section{A TUTELA INIBITÓRIA E A PREVENÇÃO DO ASSÉDIO MORAL}

Tá vendo aquele colégio, moço?

Eu também trabalhei lá

Lá eu quase me arrebento,

Pus a massa, fiz cimento,

Ajudei a rebocar

Minha filha inocente

Vem pra mim toda contente,

Pai, vou me matricular

Mas me diz um cidadão,

Criança de pé no chão

Aqui não pode estudar 285

\subsection{Considerações iniciais}

$\mathrm{Na}$ linha do que foi exposto no capítulo 3, supra, uma das possibilidades de construção de novas soluções no processo é justamente a tutela jurisdicional preventiva, ou simplesmente tutela inibitória ${ }^{286}$. Mas para alcançar sua efetividade é preciso superar algumas ideias que prevalecem na ciência do processo há muito tempo.

O direito processual viveu no fim do século XIX e início do século XX o que se pode chamar de fase de autonomia científica, isto é, houve uma consolidação da autonomia do direito processual em relação ao direito material. $\mathrm{O}$ direito processual deixou de ser um apêndice do direito material para alcançar o patamar de ciência autônoma e independente.

Tal fase, se de um lado gerou um inegável desenvolvimento à ciência processual, de outro terminou por implicar uma visão abstrata do processo, com total separação do direito material a que ele serve. O processualista de um modo geral passou a ter a tendência de ver o processo com uma sensível distância do direito material em

${ }^{285}$ Zé Geraldo. "Cidadão”. In: Terceiro Mundo. São Paulo: CBS, 1981.

286 "La tutela inhibitoria se presenta como idónea para proteger aquellos derechos que no tienen um equivalente pecuniario o que teninéndolo no cumplen con una función patrimonial." (VILLEGAS, Aldo Zela. Los ámbitos de aplicación de la tutela inhibitoria y la jurisprudencia peruana. Genesis. Revista de Direito Processual Civil. Curitiba, ano 10, número 36, abr/jun 2006, p. 357). 
discussão, como que para evitar a "contaminação" das categorias processuais pelas manchas da realidade, da efetiva lide que deve ser solucionada. Criou-se uma abstração excessiva no manejo do processo, como decorrência da busca de autonomia científica ${ }^{287}$.

Essa abstração não decorre, todavia, exclusivamente da fase autonomista do direito processual. Existiu também, evidentemente, uma forte influência da ideologia liberal da época, que pregava a mínima intervenção estatal na esfera jurídica dos indivíduos (individualismo), e que moldou a figura do juiz como ser imparcial e neutro ${ }^{288}$.

Pode-se, assim, ver o processo clássico liberal como um processo dirigido por um juiz neutro em relação à discussão concreta da causa, que manejava abstratamente institutos processuais, sempre com a preocupação de interferir o mínimo possível na esfera de liberdade dos indivíduos 289 .

Cabia à perfeição nessa modalidade de processo a estrutura de procedimento que posterga a satisfação do direito do autor a um momento posterior ao trânsito em julgado de uma sentença condenatória, que impõe ao réu uma obrigação de pagar indenização equivalente ao prejuízo comprovado, e que pode ser executada segundo o rito minuciosamente previsto na lei (execução forçada por expropriação).

É preciso perceber que a esse processo em geral não interessa qual é o direito alegadamente violado, e nisso reside o caráter abstrato antes mencionado. Não se avalia a importância ou o peso das posições jurídicas de autor e réu, não há diferenças decorrentes

\footnotetext{
287 “A técnica passou a imperar, e era considerada valor quase-absoluto, acima até mesmo do próprio direito material, que foi relegado a plano inferior. A observância das regras processuais era mais importante que a solução da questão substancial.” (BEDAQUE, 2007, p. 19)

288 "Para a burguesia no poder, não havia que se dar ao juiz grande independência, formado que fora no sistema anterior, acostumado que estava a uma ordem jurídica plena de privilégios e desigualdades. Não lhe poderia ser atribuída, portanto, a moralização do processo civil, sobretudo para avaliar o dano; competia-lhe apenas aplicar, se possível literalmente, o texto legal.” (MORAES, M. C. B., 2003, p. 201).

289 “Este modelo de 'processo', que pode ser chamado de 'processo civil clássico', além de refletir, sobre o plano metodológico, as exigências da escola sistemática, baseadas na necessidade de isolar o processo do direito material, espelha os valores do direito liberal, fundamentalmente a neutralidade do juiz, a autonomia da vontade, a não ingerência do Estado nas relações dos particulares e a incoercibilidade do facere." (MARINONI, L. G. Tutela inibitória: individual e coletiva. 5 ed. São Paulo: Editora Revista dos Tribunais, 2012 , p. 25). O mesmo autor, em outra obra, relata que "a intenção de depurar o processo civil de sua contaminação pelo direito substancial, a ele imposta pela tradição jurídica do século XIX, levou a doutrina chiovendiana a erguer as bases de um 'direito processual civil' completamente despreocupado com o direito material”. (MARINONI, 2008, p. 43).
} 
da natureza do bem jurídico envolvido na discussão. O processo é sempre o mesmo, a atuação do juiz é sempre a mesma e a forma de execução é sempre a mesma ${ }^{290}$.

Em um contexto como esse, não havia espaço para uma tutela jurisdicional preventiva $^{291}$.

Hoje, porém, a realidade social é outra e exige do Estado uma postura diferente no manejo do processo, entendido como ferramenta de garantia de direitos fundamentais ${ }^{292}$. A Constituição prevê e garante direitos que não podem ser satisfeitos por meio de uma indenização em dinheiro; direitos diretamente relacionados à dignidade, à honra, à integridade física e psíquica, ao meio ambiente, que reclamam proteção jurisdicional efetiva, de modo a impedir a violação de sua essência, e não apenas o remédio tardio da reparação de danos ${ }^{293}$.

O processo em geral, e o processo do trabalho em particular, não pode mais se contentar com as soluções tipificadas na legislação ${ }^{294}$, que em sua grande maioria preveem a conversão da obrigação em ressarcimento, em indenização de perdas e danos. Precisa ser revisto o dogma de cunho liberal pelo qual a esfera jurídica do réu apenas pode ser

\footnotetext{
290 "A tutela ressarcitória, limitando-se a exprimir o equivalente pecuniário do bem almejado, nega as necessidades de determinado grupo ou classe e a diversidade de importância dos bens. Nada mais natural quando o objetivo é apenas preservar o funcionamento do mercado, sem qualquer preocupação com a tutela das posições social e economicamente mais fracas.” (MARINONI, 2012, p. 288)

291 “A tendência em privilegiar os valores da liberdade individual em relação aos poderes de intervenção estatal não permitiu o surgimento de uma função jurisdicional preventiva. Se o valor que deveria ser preservado era a liberdade individual, com a proibição de o Estado interferir na vida dos cidadãos, qualquer ingerência sua nas relações entre os particulares sem que houvesse sido violado um direito seria vista como um atentado à liberdade individual.” (MARINONI, 2012, p. 267)

${ }^{292}$ FAVA, 2008, p. 64.

293 “[...] é possível entender a preocupação de se procurar no ordenamento jurídico não apenas um mecanismo que repare a agressão, mas que, sobretudo, evite-a. Na perspectiva dos direitos humanos, penalizar o agressor não basta, pois o mal que o desrespeito à vida representa, ainda mais quando se torna prática comum, não é jamais reposto por uma indenização. É necessário, por conseguinte, que se evite a agressão. Nesta linha de preocupação é que surge a tutela inibitória [...]” (SOUTO MAIOR, 2005, p. 216).

${ }^{294}$ Como bem lembra BEDAQUE, a "forma na medida certa é fator de garantia. A ausência dela enseja abusos, normalmente por parte dos mais fortes. O formalismo exagerado, todavia, é sinônimo de burocracia, escudo utilizado pelos covardes e preguiçosos para esconder-se." (2007, p. 25). "Mas processo não é, e nem poderia ser, somente forma. Toda a organização e a estrutura desse mecanismo encontram sua razão de ser nos valores e princípios constitucionais por ele incorporados. A técnica processual, em última análise, destina-se a assegurar o justo processo, ou seja, aquele desejado pelo legislador ao estabelecer o modelo constitucional ou devido processo constitucional." (ibidem, p. 26, grifo no original).
} 
invadida após uma exaustiva cognição judicial e também depois de a sentença transitar em julgado.

No âmbito do direito do trabalho essa insensibilidade à prevenção é notoriamente maléfica. Como já exposto no capítulo anterior, o assédio moral na relação de emprego enseja a violação de direitos fundamentais de trabalhadores e, nesse aspecto, reclama também mais do processo do que meras indenizações pecuniárias a ser pagas após o trânsito em julgado e um interminável procedimento de execução por expropriação.

Além disso, o trabalhador busca o Poder Judiciário com urgência, na grande maioria dos casos; busca no processo a satisfação de direitos fundamentais, ligados à sua sobrevivência e à de sua família. Esse processo não pode, então, relegar toda a possibilidade de satisfação do direito da pessoa para depois do trânsito em julgado de uma sentença condenatória - o que, na prática brasileira, pode durar anos.

Mas é o que tem ocorrido.

As ações de cunho preventivo existem em proporção ínfima; e também a concessão de tutela antecipada no processo do trabalho tem sido reservada acima de tudo a liberações de alvarás para levantamento de FGTS e seguro-desemprego (atos que a rigor não afetam em nada a esfera jurídica do réu). Mesmo a reintegração de empregado estável (dirigente sindical, gestante e outros casos) parece ser excepcional, justamente porque se tem em mente desde logo a indenização posterior.

É inegável que a sociedade contemporânea não mais aceita esse cenário, de insuficiência e ineficiência do processo. A proposta é que o enfoque da atuação do Poder Judiciário mude. O juiz deve estar presente não para constatar a violação ao direito e determinar o pagamento de uma indenização por isso. O juiz deve atuar no sentido de se evitar a lesão ao direito ${ }^{295}$. Daí a importância da tutela inibitória.

\footnotetext{
295 "Parece estar em processo de superação a clássica figura, típica do dinamismo patriarcal, do magistrado neutro, ascético cumpridor da lei e distante das partes e da sociedade." (PRADO, Lídia Reis de Almeida. $O$ juiz e a emoção. 5 ed. Campinas: Editora Millennium, p. 103).
} 
É bem verdade que existem fortes resistências a conceber o juiz com esse papel político relevante. É arraigada a noção de que o princípio da separação de poderes conduz o juiz a ser um frio espectador dos embates sociais ${ }^{296}$, os quais são decididos, à luz da letra da lei, com imparcialidade, noção que tem sido deturpada para significar neutralidade e desinteresse ${ }^{297}$. Por isso a clássica relevância de aspectos como a iniciativa de parte, a vedação à atuação ex officio do juiz, a vedação ao julgamento ultra ou extrapetita, entre tantos outros. A visão tradicional é a do juiz meramente técnico, que fornece soluções a conflitos mediante mera interpretação da vontade legislativa ${ }^{298}$ (da lei em sentido estrito), e para quem não faz a menor diferença saber quais são os efeitos sociais concretos de suas decisões.

\footnotetext{
${ }^{296}$ Nesse sentido, a proposição de que "a realidade dos fatos sempre fica obscurecida quando quem quer conhecê-la dela faz parte. Não é por outro motivo que o julgador deve ser, sempre, um 'terceiro desinteressado', alheio à lide" (GIDI, Antônio. Coisa julgada e litispendência em ações coletivas. São Paulo: Saraiva, 1995, p. 133).

Hoje, porém, é insustentável conceber o juiz como um ser estranho à sociedade na qual está, indubitavelmente, inserido. "Não é, portanto, o magistrado, de carreira ou não, mero expectador, ou autômato, ou simples aplicador de lei escrita, mas sim o intérprete da realidade, o tradutor da mens legis, o elemento destacado da sociedade para fazer justiça" (BITTAR, Carlos Alberto. A missão do juiz no processo moderno. Revista dos Tribunais, ano 83, v. 704, junho/1994, p. 266).
}

297 "Polarizada em interesses antagônicos, a sociedade produz conflitos entre os antagonistas. Estes conflitos, de regra, confluem para o Poder Judiciário. A decisão judicial não é neutra, mas sempre opção por uma ou outra ideia em choque." (PORTANOVA, Rui. Motivações ideológicas da sentença. 5 ed. Porto Alegre: Livraria do Advogado, 2003, p. 63). "É por isso que não há falar em neutralidade judicial. O juiz que escreveu um artigo de doutrina sobre determinado tema jurídico não está impedido de atuar num feito em que o mesmo tema esteja em questão. Assim também um juiz negro pode julgar um caso de racismo, uma juíza pode julgar um machista. Por igual, um juiz homossexual não é suspeito em processo que envolva direitos e obrigações oriundas de uniões afetivas entre pessoas do mesmo sexo." (ibidem, p. 143).

José Carlos Barbosa MOREIRA, em estudo sobre a imparcialidade do juiz, ministra esta indispensável lição: "Dizer que o juiz deve ser imparcial é dizer que ele deve conduzir o processo sem inclinar a balança, ao longo do itinerário, para qualquer das partes, concedendo a uma delas, por exemplo, oportunidades mais amplas de expor e sustentar suas razoes e de apresentar as provas de que disponha. Tal dever está ínsito no de 'assegurar as partes igualdade de tratamento', para reproduzir os dizeres do art. 125, I, do CPC. Outra coisa é pretender que o juiz seja neutro, no sentido de indiferente ao êxito do pleito. Ao magistrado zeloso não pode deixar de interessar que o processo leve a desfecho justo; em outras palavras, que saia vitorioso aquele que tem melhor direito. Em semelhante perspectiva, não parece correto afirmar, sic et simpliciter, que para o juiz 'tanto faz' que vença o autor ou que vença o réu. A afirmação só se afigura verdadeira enquanto signifique que ao órgão judicial não é lícito preferir a vitória do autor ou a do réu, e menos que tudo atuar de modo a favorecê-la, por motivos relacionados com traços e circunstâncias pessoais de um ou de outro: porque o autor é X, simpático, ou porque o réu é $\mathrm{Y}$, antipático, ou vice-versa. Repito, porém: ao juiz não apenas é lícito preferir a vitória da parte que esteja com a razão, seja ela qual for, senão que lhe cumpre fazer tudo que puder para que a isso realmente se chegue - inclusive, se houver necessidade, pondo mãos à obra para descobrir elementos que lhe permitam reconstituir, com a maior exatidão possível, os fatos que deram nascimento ao litígio, pouco importando que, afinal, sua descoberta aproveite a um ou a outro litigante." (Imparcialidade: reflexões sobre a imparcialidade do juiz. Revista Jurídica Nota Dez. Porto Alegre, ano 46, número 250, agosto/1998, p. 9). No mesmo sentido, cf. BEDAQUE, 2001, p. 107-109.

298 “A concepção meramente declaratória da sentença seria apenas um excesso de lógica, correspondendo a uma representação extremamente simplificada do processo de formação das decisões. Cabe, pois, ao juiz, realizar opções de caráter valorativo e político - que impedem sua redução à mera figura de um computador, que possuiria respostas padronizadas para todas as questões propostas." (CORREIA, 1994, p. 6) 
Entretanto, a postura exigida do Poder Judiciário, hoje, é a postura efetiva de uma função do poder do Estado (que é uno) ${ }^{299}$. O mesmo Estado que legisla e administra é o que atua no processo, perante os membros da sociedade, dirimindo controvérsias, consolidando direitos, atuando a lei, ouvindo e permitindo que a voz dos atores sociais seja ouvida. Não se espera do juiz que seja um funcionário burocrata que confere a solução das lides com a mera leitura das soluções escritas nas leis pelo Poder Legislativo, ou as escritas pelo Executivo em normas diversas ${ }^{300}$. Espera-se mais do juiz ${ }^{301}$.

O Poder Judiciário assumiu uma importância notável na democracia brasileira. É no processo judicial que as diversas classes sociais postulam o reconhecimento de direitos e exigem o cumprimento de obrigações da parte de outras pessoas e mesmo do próprio Estado. O processo tem a função de veicular a influência das pessoas comuns no cenário político e social do país ${ }^{302}$. Por isso, o juiz, ao dirigir o processo e ao sentenciar a

\footnotetext{
299 "No estágio atual da ciência do direito, a atividade jurisdicional assume relevantíssimo valor político, mas, em contrapartida, não se aceita mais decisão vinculada, inocente e mecanicamente, à ideologia inserida na lei. [...] O juiz é um agente político do Estado e do Poder. Foi investido nessa função por critérios estabelecidos na Constituição e mediante a forma legal. O juiz deve ser a expressão da democracia. Diante disso, não há razão para enclausurar o julgador em cubículos formais de procedimento, sem liberdade de movimento, e com pouquíssima liberdade criativa." (PORTANOVA, 2003, p. 122-123). Até porque, segundo VIANA, "por mais que se esforce, o juiz jamais será um mero técnico que aplica leis. Mesmo que não o perceba, nem o queira, haverá sempre um componente ideológico em suas decisões" (1996, p. 404).
}

${ }^{300}$ Lídia Reis de Almeida PRADO, ao tratar do arquétipo do juiz no Brasil, diz que ele "é coletivamente percebido como um personagem um tanto anacrônico, que trabalha sem a presteza esperada pelas partes, um ser distante, instalado em pomposos locais de trabalho." (2010, p. 42).

301 “Um vizinho muito próximo do formalista é o juiz acomodado, o que se afirma apolítico e entende que não é tarefa sua fazer indagações sobre a justiça, a legitimidade e os efeitos sociais das leis. Esse é, possivelmente, o caso da maioria dos juízes." (DALLARI, 2007, p. 40). "Com efeito, a sociedade espera do juiz, no fundo, a garantia dos seus direitos, que somente pode se concretizar na citada integração valorativa e na real independência do Poder Judiciário” (BITTAR, 1994, p. 266).

302 Rui PORTANOVA sustenta que "o processo vai ser visto teleologicamente como instrumento de participação política do indivíduo no centro das decisões do Estado" (2003, p. 101). Ana Paula de BARCELLOS enfatiza que "parte da sociedade (no Brasil e também em outros países), descrente do processo político normal, alimenta a expectativa de que o Judiciário seja afinal um espaço onde possam desenvolver-se de maneira mais lisa a discussão e a definição de políticas públicas” (2005, p. 16).

Pode-se mesmo dizer, com Maria Celina Bodin de MORAES, que "o Direito converte-se em arena privilegiada - e seguramente mais legítima - para o debate entre as diversas concepções acerca do modo como a pessoa e o grupo social devem interagir, equilibrando-se mutuamente" (2003, p. 20).

Também DINAMARCO parece concordar com essa visão, ao asseverar que "o exercício da ação e da defesa, ao longo do procedimento e ao lado dos atos de jurisdição, constitui ao mesmo tempo cooperação trazida para o correto exercício desta e participação que não pode ser obstada aos interessados”. (2013, p. 134). 
pretensão, não pode ser um burocrata; deve ser um verdadeiro agente político ${ }^{303}$. E principalmente ter a visão do alcance político de sua função ${ }^{304}$.

Nesse contexto, a tutela jurisdicional preventiva é medida a ser valorizada. Aliás, a palavra prevenção está muito em voga nos domínios do direito do trabalho, quase sempre ligada a questões de acidente do trabalho e também de segurança e saúde no trabalho $^{305}$, inclusive em âmbito internacional ${ }^{306}$.

Então, o processo do trabalho deve ser aparelhado para acompanhar essas prioridades. O juiz do trabalho deve assumir sua função política e social e concretizar as aspirações da comunidade no tocante à prevenção de lesões a direitos fundamentais dos

\footnotetext{
303 "No estágio atual da Ciência do Direito, a atividade jurisdicional assume relevantíssimo valor político, mas, em contrapartida, não se aceita mais decisão vinculada, inocente e mecanicamente, à ideologia inserida na lei. [...] O juiz é um agente político do Estado e do Poder. Foi investido nessa função por critérios estabelecidos na Constituição e mediante forma legal. O juiz deve ser a expressão da democracia. Diante disto, não há razão para enclausurar o julgador em cubículos formais de procedimento, sem liberdade de movimento, e com pouquíssima liberdade criativa [...]. Está-se a exigir dos magistrados um saber liberto da lei, multidisciplinar, antidogmático e antiformalista [...]. Claro, não é defeso adotar a lei ou a jurisprudência nos julgamentos. O que está fora de cogitação é repetir a lei sem reflexão sobre o justo no caso concreto e sem apreciação adequada às necessidades sociais, econômicas e políticas da época." (PORTANOVA, 2003, p. 122-123)

"Na verdade o direito é sempre político, por suas origens e por seus efeitos sobre os indivíduos enquanto participantes necessários da convivência, com seus valores e seus interesses que só se realizam no social, bem como sobre os grupos sociais e a sociedade como um todo. A afirmação da neutralidade política do direito é equivocada ou maliciosa." (DALLARI, 2007, p. 59).
}

304 “O momento atual é marcado pela forte interpenetração entre Poderes, com o reconhecimento, inclusive, da possibilidade de judicialização de políticas públicas, e, como reflexo processual, pelo aparecimento de instrumentos de participação mais ativa dos cidadãos nos processos decisórios, como é o caso da ação civil pública, marcadas pelo papel vocalizador de anseios sociais por seus entes legitimados." (FABRE, Luiz Carlos Michele. LAVEZO, Taís. Tutela inibitória na ação civil pública trabalhista. O Trabalho. Curitiba, número 166, dezembro/2010, p. 5933)

305 É nesse contexto que se vê no Brasil o Programa Nacional de Prevenção de Acidentes de Trabalho (Trabalho Seguro), capitaneado pelo Tribunal Superior do Trabalho (TST) e pelo Conselho Superior da Justiça do Trabalho (CSJT). O programa visa "à formulação e execução de projetos e ações nacionais voltados à prevenção de acidentes de trabalho e ao fortalecimento da Política Nacional de Segurança e Saúde no Trabalho" (Cfr. http://www.tst.jus.br/web/trabalhoseguro/apresentacao, acesso em 28.10.2013).

${ }^{306}$ É importante referir, quanto ao âmbito internacional, as edições do Congresso Mundial de Saúde e Segurança do Trabalho, organizado pela OIT e pela Associação Internacional de Seguridade Social (AISS). O Congresso se realiza a cada três anos, desde 1955, e tem alcançado a adesão de cerca de 140 países. Em 2011 realizou-se o $19^{\circ}$ Congresso, na Turquia, no qual foi publicada a "Declaração de Istambul", que, além de qualificar o meio ambiente do trabalho seguro e sadio como direito fundamental, exorta os países aderentes à "construção e a promoção de uma cultura nacional sustentável de prevenção". A $20^{a}$ ediçãa do Congresso está prevista para agosto/2014, na cidade de Frankfurt, Alemanha. 
trabalhadores (entre as quais o assédio moral e a violação à saúde psíquica detêm inegável relevância) $)^{307}$.

A tutela inibitória se apresenta, portanto, como técnica bastante útil para atingir esse objetivo.

\subsection{Uma premissa necessária: ato ilícito e dano}

A doutrina que constrói o regime da tutela inibitória se esforça para modificar uma noção arraigada no direito civil: a de que só pode existir ato ilícito se houver dano causado a alguém.

Tradicionalmente, uma das notas conceituais da ilicitude (ou antijuridicidade) é o dano. Não por outra razão o art. 186 do Código Civil brasileiro dispõe: "aquele que, por ação ou omissão voluntária, negligência ou imprudência, violar direito $e$ causar dano $a$ outrem, ainda que exclusivamente moral, comete ato ilícito”.

Todavia, na esteira do que se vem de sustentar, essa noção deve ser revista. É admissível que uma determinada conduta contrarie o ordenamento jurídico em sua prática mesma, sem que se cogite a princípio de um dano efetivo. São momentos distintos: em primeiro lugar se dá a prática do ato pelo sujeito, ato esse que afronta uma norma jurídica; como consequência, pode ocorrer que esse mesmo ato implique um prejuízo para outro sujeito, caracterizando o dano decorrente do ilícito. Todavia, não é correto identificar a ilicitude com a geração do dano. Este pode, por uma ou outra razão, não se concretizar, e seria ilógica a conclusão de que essa circunstância torna lícita a conduta do sujeito que afrontou o ordenamento jurídico.

\footnotetext{
307 "[A] tutela inibitória se apresenta como resposta à chamada crise da modernidade (a idéia de que as promessas da modernidade - liberdade, igualdade e fraternidade - não forma devidamente cumpridas), mesclando-se com pensamentos neopositivistas e voltando-se as demandas do chamado juspositivismo garantista, filosofia jurídica que reformulará conceitos de existência, validade e eficácia a partir da constatação de que conquanto a ordem jurídica seja garantista, porquanto reconhecedora de uma vasta gama de direitos fundamentais, a prática jurídica não o é, porquanto desvirtuada por determinados vícios perpetuados sob o rótulo da cientificidade” (FABRE e LAVEZO, 2010, p. 5933).
} 
Uma coisa, portanto, é a antijuridicidade, a ilicitude; outra coisa é o dano causado pelo ato ilícito. O dano é consequência eventual e não necessária do ato ilícito, não um seu componente conceitual ${ }^{308}$.

Essa forma de ver o fenômeno da ilicitude favorece a aplicação prática de uma tutela jurisdicional tendente à prevenção do ilícito. Com efeito, se é preciso conferir mais importância à prevenção de lesão de direitos e, consequentemente, aparelhar o processo para que atue preventivamente, não se pode, de outro lado, exigir que o provimento jurisdicional só possa ser conferido a quem demonstrar que tenha sofrido dano injusto em seu direito, ou demonstrar a probabilidade do dano.

A tutela jurisdicional preventiva é aquela a ser prestada antes que se produza o dano; logo, até esse momento, a conduta do réu de fato não causou dano algum. E a finalidade da tutela inibitória é exatamente evitar a prática do ato ilícito e, consequentemente, a produção do dano ${ }^{309}$.

Não se pode interpretar que a conduta do réu, apenas por não ter causado (até então) nenhum dano, seja necessariamente lícita. Agir em desacordo com a ordem jurídica é praticar ato ilícito. O dano é uma consequência acidental da ilicitude (pode ou não ocorrer), e com ela não se confunde ${ }^{310}$. Por isso é que, constatando o juiz que foi ou provavelmente será praticado ato ilícito que pode vir a causar o dano temido pela vítima, o

\footnotetext{
${ }^{308}$ PONTINHA, 2009, p. 201.

309 CORDEIRO, Wolney de Macedo. A tutela inibitória como elemento concretizador das medidas antidiscriminatórias no âmbito da relação de trabalho. Jus Navigandi. Teresina, ano 13, n. 2075, 7.3.2009, p. 10. (Disponível em http://jus2.uol.com.br/doutrina/texto.asp?id=12407 Acesso em 16.10.2010).
}

310 Sergio CAVALIERI FILHO, após colacionar diversos entendimentos doutrinários acerca das notas conceituais da ilicitude, sustenta que "o conceito estrito de ato ilícito, tendo a culpa como um de seus elementos, tornou-se insatisfatório até mesmo na responsabilidade subjetiva. Em sede de responsabilidade civil objetiva, cujo campo de incidência é hoje vastíssimo, só tem guarida o ato ilícito lato sensu, assim entendido como a mera contrariedade entre a conduta e a ordem jurídica, decorrente da violação de dever jurídico preexistente". (Programa de responsabilidade civil. 6 ed. São Paulo: Malheiros, 2005, p. 32-33). Note-se que essa noção de "mera contrariedade entre a conduta e a ordem jurídica" coincide com o que se vem de sustentar no presente tópico, isto é, o dano não é elemento conceitual da ilicitude. Na mesma obra, páginas à frente, o autor parece ratificar essa proposição, à vista da cuidadosa exposição acerca do conceito de dano: "sem o dano, não haverá o que reparar, ainda que a conduta tenha sido culposa e até dolosa [...]. Daí a afirmação, comum praticamente a todos os autores, de que o dano é não somente o fato constitutivo mas, também, determinante do dever de indenizar" (ibidem, p. 95-96). Perceba-se, o dano compõe o dever de indenizar, não o conceito de ilicitude. 
provimento inibitório será cabível, de modo a proibir a reiteração da conduta e, consequentemente, evitar a produção do dano.

Mas a categoria que diretamente influi na análise e concessão da tutela inibitória é a do ilícito, não a do dano. Não é preciso que o autor fundamente o pedido na probabilidade do dano; o que se discute na ação inibitória é a probabilidade do agir ilícito.

Essa construção não impõe contradição com a teoria geral da responsabilidade civil, segundo a qual o dano é pressuposto necessário do dever de indenizar. Não há dúvida quanto à pertinência desse pressuposto. De fato, somente pode existir dever de indenizar quando algum dano houver de ser reparado. Se não houver dano, não haverá indenização. Porém, a distinção entre ato ilícito e dano se dá em momento anterior. No momento em que não é cabível a indenização ou a reparação (porque inexiste dano), mas pode ser cabível a tutela jurisdicional preventiva da lesão. Tutela essa que, tempestiva e adequada, trará como efeito a proteção em face da lesão do direito e, consequentemente, evitará qualquer discussão acerca da responsabilidade civil ou dever de indenizar.

Nesse sentido, para MARINONI, "é preciso deixar claro que o dano é uma consequência meramente eventual do ato contrário ao direito. $\mathrm{O}$ dano é requisito indispensável para a configuração da obrigação ressarcitória, mas não para a constituição do ilícito". 311

Por essas razões é que não faz sentido pensar em tutela inibitória ou preventiva com os pressupostos da responsabilidade civil ou do dever de indenizar. Aqui reside a importância da distinção entre ato ilícito e dano, que se afigura essencial para a correta compreensão dos pressupostos da tutela inibitória.

\footnotetext{
${ }^{311}$ MARINONI e ARENHART, Manual do processo de conhecimento. 5 ed. São Paulo: Editora Revista dos Tribunais, 2006, p. 439. No mesmo sentido: FABRE e LAVEZO, 2010, p. 5932.
} 


\subsection{Conceito e características da tutela inibitória.}

A tutela inibitória é prestada em "ação de conhecimento de natureza preventiva, destinada a impedir a prática, a repetição ou a continuação do ilícito" ${ }^{\text {,312 }}$. Logo, a ação inibitória é uma ação de conhecimento preventiva. MARINONI salienta que

A ação inibitória é consequência necessária do novo perfil do Estado e das novas situações de direito substancial. Ou seja, a sua estruturação, ainda que dependente de teorização adequada, tem relação com as novas regras jurídicas, de conteúdo preventivo, bem como com a necessidade de se conferir verdadeira tutela preventiva aos direitos, especialmente aos de conteúdo não-patrimonial. ${ }^{313}$

Funda-se a ação inibitória individual nas disposições do art. 461 do Código de Processo Civil, e a ação de caráter coletivo no art. 84 do Código de Defesa do Consumidor, conforme se verá com mais vagar em tópico posterior.

É importante ressaltar que a tutela inibitória destina-se à prevenção em face da conduta ilícita, a qual, como se viu antes, não se confunde com o dano. Ou seja, a discussão a ser travada em ação inibitória não diz respeito ao dano ou à probabilidade de sua produção, mas sim ao próprio agir ilícito do réu ${ }^{314}$.

No campo de aplicação da presente pesquisa (o assédio moral na relação de emprego), é visível o ganho de eficácia proporcionado pela objetividade da discussão na ação inibitória: não se haverá de discutir a possibilidade, ou probabilidade, de geração de dano à vítima pela conduta alegadamente abusiva. Logo, não se estenderá a matéria

\footnotetext{
${ }^{312}$ MARINONI, 2012, p. 32.

${ }^{313}$ MARINONI, L. G. Tutela inibitória e tutela de remoção do ilícito. Jus Navigandi. Teresina. Ano 9. n. 272, 5 abr 2004, p. 2. Disponível em <http://jus.com.br/revista/texto/5041. Acesso em 23.6.2012.

${ }^{314}$ MARINONI salienta que "essa ação não requer nem mesmo a probabilidade do dano, contentando-se com a simples probabilidade de ilícito (ato contrário ao direito). Isso por uma razão simples: imaginar que a ação inibitória se destina a inibir o dano implica na suposição de que nada existe antes dele que possa ser qualificado de ilícito civil. Acontece que o dano é uma conseqüência eventual do ato contrário ao direito, os quais, assim, podem e devem ser destacados para que os direitos sejam mais adequadamente protegidos" (2004, p. 3).
} 
probatória até esse ponto. A questão é inquirir acerca da ilicitude da conduta praticada ou em vias de ser praticada no ambiente de trabalho.

Com isso se evita um grande problema: o do nexo de causalidade entre danos psicológicos das vítimas e as condutas patronais, ou os desequilíbrios do meio ambiente do trabalho. É notória, como já salientado anteriormente, a insuficiência de meios técnicos no processo para se aferir com razoável margem de segurança se todas as enfermidades psicológicas que acometem trabalhadores são mesmo causadas pelo trabalho.

$\mathrm{Na}$ ação inibitória, o que se quer é evitar que o ilícito seja praticado, continuado ou repetido. A ausência de dano será a consequência remota mais benéfica da efetividade da tutela inibitória. Não se discute o dano, nem se deve discutir se a conduta patronal é apta a gerar esse ou aquele tipo de dano físico ou psicológico no empregado. $\mathrm{O}$ objeto da discussão é, como exposto acima, o caráter ilícito da conduta ${ }^{315}$.

Como se vê pela definição, a tutela inibitória se destina a prevenir a prática, a continuação ou a repetição do ilícito. São três realidades diferentes, evidentemente, que implicarão diferenças no tratamento da pretensão, especialmente em relação à prova. A tutela inibitória preventiva da prática de um ato ilícito, antes mesmo de qualquer comportamento por parte do réu, é a chamada tutela inibitória "pura", a qual requer, como se analisará em tópico próprio, muito cuidado na produção e na valoração das provas.

A tutela inibitória pode se destinar à prevenção da continuação do ilícito, situação na qual o réu já pratica o ato ilícito temido, e a pretensão do autor é a cessação dessa prática; o autor quer que o ato deixe de ser praticado.

Por fim, a pretensão do autor da ação também pode ser evitar a repetição de um ato ilícito que o réu já praticou e que possa vir a praticar novamente. Não seria nesse caso um ato continuado, e sim um ato que já foi praticado no passado e que segundo fundada suspeita do autor pode ser novamente praticado pelo réu.

\footnotetext{
315 MARINONI é enfático ao sustentar que "o que se quer deixar claro é que para a obtenção da tutela inibitória não é necessária a demonstração de um dano futuro, embora ele possa ser invocado, em determinados casos, até mesmo para se estabelecer com mais evidência a necessidade da inibitória” (2012, p. 41).
} 
Situação diferente das três mencionadas é aquela na qual o ato ilícito foi completamente praticado, e as consequências da ilicitude ainda se produzem no tempo. A tutela que, nessa situação, tenha a finalidade de remediar as consequências do ato ilícito, sem que se fale em reparação de danos, é chamada propriamente de tutela de remoção do ilícito - e não se identifica com a tutela inibitória.

A tutela de remoção do ilícito (tutela reintegratória, na classificação de MARINONI) destina-se a suprimir os efeitos de um ato ilícito já completamente praticado. Não há falar, nesse caso, em tutela inibitória, pois esta se dirige à prevenção de uma conduta; quando não existe mais conduta temida a prevenir (apenas efeitos de uma conduta já praticada), não se está a tratar de tutela inibitória ${ }^{316}$.

Para melhor esclarecimento, analisam-se alguns exemplos. Se a tutela preventiva destina-se a impedir que haja a imposição, pelo empregador, de punições humilhantes a empregados que não alcancem meta mínima de produtividade, ou a impedir que essa ilicitude seja repetida ou continuada na empresa, trata-se de verdadeira tutela inibitória.

Suponha-se, porém, na mesma linha de raciocínio, que o gerente de equipe de vendedores crie um ranking entre eles conforme o cumprimento das metas de produtividade, e coloque as informações em um quadro exposto em local de grande visibilidade no estabelecimento. Seria ilícita a conduta do gerente se ele pusesse, ao lado do nome do vendedor com mais baixa produtividade, o desenho de uma tartaruga, com evidente intuito de constrangê-lo. A pretensão do empregado (ou de algum ente legitimado a agir em seu favor) poderia ser, então, de retirar esse quadro do local, independentemente da discussão acerca da existência de dano a ser reparado. Trata-se nessa hipótese de tutela de remoção do ilícito, pois não se pretende prevenir uma conduta, mas sim suprimir efeitos de uma conduta ilícita já praticada.

\footnotetext{
${ }^{316}$ Até porque "existe diferença entre impedir o agir ilícito e remover o ilícito cujos efeitos estão repercutindo no tempo.” (MARINONI, 2012, p. 130). Cf. também FABRE e LAVEZO, 2010, p. 5935.
} 


\subsection{Justificação da tutela inibitória. Importância da prevenção do assédio moral.}

A base da tutela inibitória é o direito fundamental de ação, entendido como o direito a uma tutela jurisdicional tempestiva e adequada. Nesses termos, será tempestiva a tutela jurisdicional quando incide a tempo de manter a integridade do direito tutelado; em outras palavras, a tutela deixa de ser tempestiva quando prestada somente depois da consolidação da lesão ao direito do autor. Ainda que seja para remediar a situação com indenização de perdas e danos.

Será, ademais, adequada a tutela jurisdicional quando ela atende às peculiaridades do caso e às características do direito que se tem em discussão. Não se vê adequação na tutela ressarcitória, que condena o réu a pagar indenização de perdas e danos, se o direito tutelado tem notório conteúdo extrapatrimonial, isto é, não pode, por definição, ser convertido em pecúnia ${ }^{317}$. Nessas hipóteses, a tutela jurisdicional adequada é aquela que visa a manter a integridade do direito, restringindo-se a conversão em perdas e danos a casos extremos de impossibilidade da tutela específica.

Aliás, o inciso XXXV do art. $5^{\circ}$ da Constituição Federal dispõe expressamente que "nenhuma lei excluirá da apreciação do Poder Judiciário lesão ou ameaça a direito", redação essa que parece claramente admitir - ou, mais que isso, exigir - um instrumento processual apto a proteger os direitos contra as ameaças de lesão ${ }^{318}$.

Tendo-se em mente essas premissas, a efetividade de uma tutela preventiva, para a proteção dos direitos em face de ameaças de lesões, nada mais é do que exigência do direito fundamental de ação, prometido pelo Estado brasileiro por norma da Constituição

${ }^{317}$ CORDEIRO, 2009, p. 6.

318 "Na verdade, há direito fundamental à efetividade da tutela jurisdicional e, assim, direito fundamental à tutela preventiva, o qual incide sobre o legislador - obrigando-o a instituir as técnicas processuais capazes de permitir a tutela preventiva - e sobre o juiz - obrigando-o a interpretar as normas processuais de modo a delas retirar instrumentos processuais que realmente viabilizem a concessão de tutela de prevenção." (MARINONI, 2004, p. 2-3). Cf. também, sobre a tutela jurisdicional efetiva como direito fundamental, a lição de BEDAQUE (2007, p. 78). CANOTILHO é claro ao sustentar que "as normas - constitucionais, internacionais e legais - garantidoras da abertura da via judiciária devem assegurar a eficácia da protecção jurisdicional" (2003, p. 497). 
Federal $^{319}$. Com efeito, de nada adiantaria a promessa do direito fundamental de ação como proteção em face de ameaça de lesão se toda e qualquer situação levada ao Judiciário fosse resolvida com base em condenação a pagar indenização de perdas e danos, para execução por expropriação após o trânsito em julgado ${ }^{320}$. É dever do juiz extrair do sistema, por meio de interpretação construtiva, as técnicas capazes de cumprir a promessa constitucional de proteção dos direitos ${ }^{321}$.

Como já foi salientado, a sociedade atual não se satisfaz com a aplicação prática do processo como concebido no início do século passado. Os princípios liberais do processo, que induziam a neutralidade do juiz e a mínima intervenção na esfera jurídica do réu, foram em grande parte afetados pelo movimento de acesso à justiça, que prega uma democratização da atuação do Poder Judiciário. Este não pode mais fingir que lida apenas com proprietários em discussões pautadas pela conversão em moeda ${ }^{322}$. Hoje todas as pessoas são potenciais destinatárias dos serviços da jurisdição, e direitos novos são discutidos no âmbito judicial, direitos que não aceitam a mesma lógica da conversão em perdas e danos. Essas mudanças afetaram, como não poderia deixar de ser, o conteúdo do direito fundamental de ação.

Ora, se a conversão das obrigações em indenização de perdas e danos satisfazia os litigantes do passado e ainda satisfaz algumas situações do presente, não se pode deixar de constatar que inúmeras situações de direito material não aceitam essa lógica. No direito do trabalho, em especial, a íntima relação entre a satisfação dos direitos do trabalhador e sua sobrevivência deve induzir uma jurisdição mais atenta à função

\footnotetext{
${ }^{319}$ PONTINHA, 2009, p. 194.
}

\footnotetext{
320 "A tutela jurisdicional precisa ser efetiva. Para tanto, muitas vezes é necessário renunciar ao dogma da certeza e abrandar as garantias inerentes à segurança jurídica, a fim de evitar que o tempo deteriore a utilidade prática da tutela." (BEDAQUE, 2007, p. 87).

${ }^{321}$ Nesse sentido, para BEDAQUE, "assume grande importância o papel do processualista. É fundamental que ele consiga extrair do sistema positivo soluções aptas a compatibilizar o formalismo necessário e os objetivos do processo, para evitar que a estrita observância daquele não comprometa estes" (2007, p. 44).

322 “[Ao] protagonista do Código Civil, sujeito de direitos e proprietário, cabia somente velar por seus familiares e por seus bens, apresentando-se desvinculado do tecido social que o envolvia. Individualmente, como cidadão, ainda não havia conquistado a plenitude de seus direitos políticos e sociais, carecendo, durante o século XIX e nas primeiras décadas do século $\mathrm{XX}$, dos poderes legais que lhe iriam permitir atuar politicamente" (MORAES, M. C. B., 2003, p. 103).
} 
preventiva contra as ameaças de lesão a direitos, nos estritos termos do inciso XXXV do art. $5^{\circ}$, já mencionado. É um novo direito de ação.

E esse novo direito de ação deve partir da lógica da proteção aos direitos fundamentais $^{323}$. Trata-se da lógica da tutela específica dos direitos e da prevenção das lesões, pois os direitos fundamentais são, por definição, invioláveis e inalienáveis. Uma vez praticada, a lesão a direito fundamental não pode ser reparada com dinheiro; uma indenização nesse tipo de situação nada mais é que um paliativo, uma compensação para a vítima, que não terá como ver seu patrimônio jurídico verdadeiramente restaurado ${ }^{324}$.

Vista a realidade por esse prisma, não há como não perceber que, se o processo permanecer atuando apenas segundo a lógica da reparação de prejuízos por perdas e danos, estará não apenas negando vigência ao direito fundamental de ação com o conteúdo qualificado da contemporaneidade, mas também e sobretudo autorizando a conclusão de que o poder econômico (privado ou público) pode expropriar os direitos fundamentais quando assim desejar.

Tal conclusão mostra-se necessária quando se vê a aplicação, no âmbito dos direitos fundamentais, do velho sistema da sentença condenatória de indenização por perdas e danos, a ser executada depois do trânsito em julgado. Esse regramento não implica menos do que a possibilidade de pagamento pelo direito fundamental alheio, pois transforma a violação em um montante pecuniário, tão-somente; montante esse que deverá ser pago em um tempo bastante longo, a considerar a realidade brasileira.

É a pura e insofismável negação da força cogente das normas de direitos fundamentais. A partir do momento em que o processo aparelha-se para tratar desses direitos apenas com a lógica da condenação ao pagamento de indenizações, tem-se a

\footnotetext{
${ }^{323}$ Sobre aspectos teóricos e de fundamentação dos próprios direitos fundamentais, vide o desenvolvimento do tema no capítulo 3, infra.

324 “A idéia de prevenção da própria ilicitude, antes mesmo da corporificação do dano, é técnica que busca, na via reflexa, conferir uma maior efetividade social aos provimentos jurisdicionais. Construiu-se, por conseguinte, no arcabouço processual brasileiro um conjunto de técnicas aptas a impedir a concretização do dano, mediante a adoção de medidas preventivas, coativas e repressivas. Não há dúvidas de que a idéia de tutela inibitória já existia de maneira dispersa em nosso ordenamento processual, conforme se vê da análise do instituto do interdito proibitório (atualmente previsto nos artigos 932 e 933 do Código de Processo Civil)." (CORDEIRO, 2009, p. 9).
} 
negação das promessas constitucionais de inviolabilidade de direitos fundamentais: não é inviolável o direito que pode ser desrespeitado mediante o pagamento de um valor em dinheiro $^{325}$. A ilicitude, vista em tal contexto, não é muito mais do que mera retórica. $\mathrm{O}$ agir ilícito pode ser "comprado", pode ser legitimado pela expectativa de reparar pecuniariamente o direito violado, em nítido pensamento mercadológico de precificação $^{326}$.

As tutelas preventivas são, portanto, uma necessidade constitucional. A técnica da tutela inibitória é exigida pelo direito fundamental de ação e não pode ser negligenciada por aspectos de legislação ordinária, portanto.

A propósito, é preciso desfazer o mito de que a tutela preventiva é incompatível com os poderes limitados de que o juiz dispõe no processo brasileiro. Não é verdade. O que ocorreu no Brasil foi uma clara opção política pela proteção mais eficaz dos direitos ligados à propriedade e à posse - e, nesses casos, o juiz brasileiro há muito tempo dispõe de poderes consideráveis para a efetividade da tutela dispensada ao direito material.

Tomem-se os exemplos das ações possessórias. Na ação de interdito proibitório, o "possuidor direto ou indireto, que tenha justo receio de ser molestado na posse, poderá impetrar o juiz que o segure da turbação ou esbulho iminente, mediante mandado proibitório, em que se comine ao réu determinada pena pecuniária, caso transgrida o preceito" (CPC, art. 932). Trata-se de tutela inibitória típica, prevista no direito positivo brasileiro há muito tempo, em face da qual não se veem insurgências doutrinárias ou científicas, tampouco empíricas. Mesmo quando se percebe que o legislador não tolheu do juiz o poder de fixar a "pena pecuniária" de acordo com as características do caso concreto.

\footnotetext{
325 "Como é óbvio, um processo que só permite a cobrança de dinheiro do autor do dano não constitui resposta adequada aos direitos. Um processo desse tipo é, na realidade, um incentivo à prática de danos ou, pior, uma porta aberta à desconsideração do direito material, já que o infrator, nesse caso, somente terá que pagar o valor equivalente ao do dano - e isso quando o direito puder ser medido em pecúnia - depois de um bom tempo, o que certamente poderá ser, em termos meramente econômicos e de mercado, uma excelente opção." ((MARINONI, 2012, p. 395).

326 “As perdas e danos ou a tutela pelo equivalente seriam necessárias não só para conservar o dogma da 'neutralidade' do juiz, como também para manter em funcionamento os mecanismos do mercado. É que no 'mercado' pouco importa as qualidades do sujeito ou as dos bens, de modo que a tutela pecuniária, ao expressar apenas o custo econômico do valor da lesão, mantinha íntegros os mecanismos do próprio mercado, sem alterar a sua lógica." (MARINONI, 2008, p. 47).
} 
Não haveria, portanto, razão alguma para admiração na aplicação de regime jurídico semelhante a esse em uma técnica de tutela de direitos outros que não a posse ou propriedade $^{327}$. Em outras palavras, o regime da tutela inibitória atípica, fundada nos instrumentais dos arts. 461 do CPC e 84 do CDC. Deve-se compreender a opção ideológica que fez o legislador: embora há menos de duas décadas ${ }^{328}$ tenha esboçado um regime de tutela inibitória atípica no direito brasileiro, a proteção eficaz da posse, do ponto de vista da prevenção, já está consolidada há muito mais tempo.

Na mesma esteira de raciocínio, também a ideologia dos aplicadores do direito se vê claramente ${ }^{329}$, quando pregam a inviabilidade ou inconveniência de uma tutela inibitória atípica que fuja ao sistema da sentença condenatória, e mantêm isenta de críticas a tradicional ação de interdito proibitório ${ }^{330}$, a qual tampouco se encaixa na classificação trinária das sentenças. Veja-se que o próprio legislador admite, no art. 921 do CPC, a cumulação do "pedido possessório" ao de condenação em perdas e danos. Ora, que natureza teria esse "pedido possessório", que pode ser cumulado com o de condenação ao pagamento de indenização? Trata-se, sem dúvida, de um provimento de natureza mandamental, em tudo semelhante ao provimento mandamental que caracteriza a concessão da tutela inibitória ${ }^{331}$.

Também pode ser citada como exemplo de tutela inibitória típica, no âmbito da proteção da propriedade e da posse, a ação de nunciação de obra nova, regulada pelos

\footnotetext{
327 "O dinheiro, a posse e a propriedade não são mais os únicos valores a serem protegidos juridicamente, em razão do que se faz necessário o desenvolvimento da técnica inibitória para a proteção dos direitos não patrimoniais. Isto significa, exemplificativamente, que a tutela inibitória não deve mais se prestar a somente agasalhar o direito do empregador através dos interditos proibitórios em greves, mas também deve servir para a proteção da saúde dos trabalhadores" (PONTINHA, 2009, p. 195).

${ }^{328}$ A atual redação do art. 461 do CPC foi dada pela Lei 8.952, de 1994.

${ }^{329}$ A ideologia do intérprete influi diretamente no resultado da interpretação do direito. Quando se está a tratar do próprio julgador, é igualmente inviável tentar separar a pessoa do juiz de sua interpretação do direito. "O juiz que não tem valores e diz que seu julgamento é neutro, na verdade está assumindo valores de conservação. $\mathrm{O}$ juiz sempre tem valores. Toda sentença é marcada por valores. $\mathrm{O}$ juiz tem que ter a sinceridade de reconhecer a impossibilidade de sentença neutra." (PORTANOVA, 2003, p. 74).
}

${ }^{330}$ A contradição aí é tamanha, a ponto de ser frequente o uso da ação preventiva de interdito proibitório na Justiça do Trabalho, por parte de empregadores, contra a "turbação" temida em movimentos grevistas, por exemplo.

${ }^{331}$ Sobre a natureza mandamental do provimento que concede a tutela inibitória, vide tópico 5.5, infra. 
arts. 934 e seguintes do mesmo CPC. Também esse procedimento é destinado a evitar a lesão a direitos do proprietário ou possuidor, e prevê expressamente a aplicação de pena para inobservância da ordem judicial (art. 936, inciso II) e a adoção de medidas executivas eficazes a cada caso concreto (parágrafo único do art. 936).

Esclareça-se que não se está a sugerir que a proteção dispensada à posse e à propriedade pelas ações possessórias e de nunciação de obra nova sejam inadequadas. Pelo contrário, são legítimas técnicas de tutelar adequadamente o direito material, pois preconizam a prevenção da lesão; têm caráter inegavelmente preventivo. O que se deve pôr em relevo é o fato de que a técnica da tutela preventiva deve, por imperativo do direito fundamental de ação, ser ampliada genericamente a todos os direitos que mereçam proteção mais eficaz que a reparação pecuniária - em especial os direitos fundamentais.

No que diz respeito mais diretamente ao âmbito desta pesquisa, não existe uma razão legítima do ponto de vista constitucional para que a tutela jurisdicional em face do assédio moral na relação de emprego seja menos eficaz do que a tutela dispensada aos direitos de propriedade e de posse $\mathrm{e}^{332}$. Ora, se para a proteção adequada aos direitos do proprietário e do possuidor pode o juiz extrapolar os estritos limites do sistema clássico da sentença condenatória, indenização de perdas e danos e execução por expropriação, com mais razão ainda deverá ele agir assim para a proteção da dignidade dos trabalhadores, para evitar a prática ou continuação do assédio moral no trabalho. Afinal, tem-se em mente um ordenamento jurídico cujos fundamentos são, entre outros, a dignidade da pessoa e o valor social do trabalho (CF, art. $1^{\mathrm{o}}$, incisos III e IV).

\subsection{Operacionalização da tutela inibitória. Meios executivos.}

Já foi salientado que a tutela inibitória é prestada em ação de conhecimento, mas convém reforçar essa questão, tendo em vista o uso tradicional, no direito processual

\footnotetext{
332 Aliás, é interessante a crítica de MARINONI nesse sentido. Após mencionar as ações de interdito proibitório e de nunciação de obra nova, de nítida feição inibitória, ele refere que "é realmente algo para estranhar, especialmente porque tais direitos têm conteúdo patrimonial, ao contrário de outros de conteúdo não patrimonial, como os direitos da personalidade, aos quais não se outorgou essa espécie de tutela" (2008, p. 64).
} 
civil brasileiro, das ações cautelares inominadas para obter verdadeira tutela preventiva do direito material.

A ação cautelar tem a finalidade de assegurar o resultado útil de outra ação, na qual se discute diretamente o direito material. Trata-se, por assim dizer, de uma ação instrumental em relação ao próprio processo, pois a proteção é dispensada ao resultado do processo dito principal. Em alguns casos, pode-se ajuizar a ação cautelar antes da ação principal, mas a lei prevê o caráter acessório da cautelar ao exigir o ajuizamento da ação principal em determinado prazo (CPC, art. 806).

Levando-se em consideração essas proposições, não faria sentido falar em "ação cautelar satisfativa", ou seja, uma ação que, embora qualificada como cautelar, proporcionasse ao autor a tutela por ele pretendida em favor de seu direito. Até porque, como se disse, a tutela cautelar se dirige a proteger o processo, não diretamente o direito material. Não obstante, o uso da ação cautelar como instrumento de proteção mais eficaz do direito material (a chamada cautelar "satisfativa") disseminou-se no Brasil há algumas décadas. Isso se deve à manifesta ineficiência do procedimento ordinário da ação de conhecimento em várias situações reais, que exigiam uma tutela mais rápida, mais efetiva e em um rito mais simples. E para isso o processo cautelar serviu como um remédio.

É de se salientar que as necessidades do direito material realmente condicionam a aplicação do direito processual. $\mathrm{O}$ uso indiscriminado da ação cautelar satisfativa evidenciou que era pouco o que o Código de Processo Civil oferecia para a tutela efetiva de vários direitos, os quais tiveram de procurar outra saída, outros instrumentos para a busca dessa tutela.

Hoje, todavia, o cenário normativo é diferente. O art. 461 do CPC prevê instrumentos mandamentais e executivos para que a proteção do direito material seja feita de forma mais eficaz, sem necessidade do uso deturpado de uma ação cautelar para alcançar a efetividade do processo. Trata-se mesmo de uma correção histórica. Na ação inibitória não se aplica a duplicidade de procedimentos que se via no uso das cautelares satisfativas de outrora (após obter um provimento liminar, era necessário que o autor propusesse a ação dita principal, ainda que fosse apenas para requerer a confirmação do provimento liminar - o que a rigor não faz o menor sentido, seja no aspecto substancial, 
seja no aspecto lógico). O manejo da ação inibitória com base nos instrumentais do art. 461 do CPC (ou, em âmbito coletivo, nos do art. 84 do CDC) é feito evidentemente em processo de conhecimento, no bojo do qual a pretensão é a proteção direta do direito material, da perspectiva do impedimento de sua violação. Já não existe, a partir desses instrumentais, razão para acreditar que a tutela inibitória enseja um pedido de provimento liminar para ser "confirmado", depois, em outro processo, dito "principal".

É verdade que a tutela inibitória enseja, via de regra, a possibilidade de emissão de provimento liminar, mas sua base é o processo de conhecimento. Uma vez superadas as fases postulatória e instrutória, o juiz proferirá sentença apta a gerar a coisa julgada material. Sem necessidade de ajuizar outra ação para ser a "principal", ou para "confirmar" a tutela prestada liminarmente.

É hora de perceber, então, que apenas a força da tradição sugere o uso da cautelar satisfativa para obter tutela preventiva de direito material. $\mathrm{O}$ direito positivo brasileiro possui hoje as ações de conhecimento preventivas que podem ser propostas com base nos arts. 461 do CPC e 84 do CDC, sem a necessidade de duplicação inútil de procedimentos, no ajuizamento das ações ditas principais.

Assentada a premissa de que se está a tratar de ação de conhecimento, e não cautelar, é preciso voltar os olhos à classificação das ações de conhecimento, e com isso constatar que a tutela inibitória não se amolda às características da ação condenatória, tampouco às da ação declaratória e às da ação constitutiva.

Tradicionalmente, as sentenças do processo de conhecimento são classificadas em três espécies: declaratória, constitutiva e condenatória. A sentença declaratória é a que simplesmente declara, para proporcionar certeza aos sujeitos envolvidos, a existência ou inexistência de uma relação jurídica. A sentença constitutiva tem a força de criar uma relação jurídica a partir de seus próprios efeitos. E a sentença condenatória é aquela que reconhece (rectius: declara) que o réu é devedor de uma determinada prestação em favor do autor e, além disso, autoriza a este o uso do aparato judiciário para promover a execução forçada do devedor, a fim de excutir-lhe parte do patrimônio para realizar o comando da sentença. 
Vê-se que do ponto de vista da tutela do direito material, tanto a sentença declaratória quanto a sentença constitutiva bastam, por si mesmas, para proporcionar ao sujeito a tutela almejada. Uma sentença que diga que o autor era empregado do réu (declaratória), máxime após transitada em julgado, basta para resolver a incerteza quanto ao vínculo de emprego, e nesse aspecto o litígio já está de pronto resolvido. Igualmente uma sentença de processo de inquérito para apuração de falta grave (CLT, art. 853-855), que conceda ao empregador a resolução contratual justificada de empregado estável, por si só é bastante a entregar ao autor da ação a tutela do seu alegado direito material. Tais sentenças não requerem a continuidade do procedimento judicial para que seja efetivamente tutelado o direito material a que elas se dirigem. São, portanto, sentenças que satisfazem.

Diferente é, nesse aspecto, a sentença condenatória. A sentença que condena mantém-se no campo da linguagem, no campo da abstração, e proporciona ao autor não a tutela de seu direito, mas sim mera possibilidade de alcançar essa tutela por outro procedimento, o procedimento de execução forçada. Transitada em julgado a sentença condenatória, a esfera jurídica do réu mantém-se inalterada, e a situação de insatisfação do autor também. Por isso, diz-se que a sentença condenatória é uma sentença que não satisfaz, por si só, a pretensão de direito material.

A eficácia prática da condenação, no processo civil e no processo trabalhista, é a autorização dada ao autor para dar início ao procedimento de execução. O que não importa satisfação imediata do direito material; aliás, em muitos casos sequer a execução alcança resultado prático que satisfaça o direito do autor, e com isso o processo se revela inútil do ponto de vista da tutela material do direito.

Questão interessante, a esta altura, é o enquadramento classificatório da sentença que defere a tutela inibitória. Tal provimento judicial é evidentemente distinto das noções de sentença declaratória e de sentença constitutiva, mas também é imperioso reconhecer que não se trata igualmente de sentença condenatória. A sentença que defere a tutela inibitória não abre ensejo à execução forçada, e tem de superar o campo da mera linguagem oficial, para determinar medidas práticas que assegurem sua eficácia. 
Trata-se de uma sentença que parte da doutrina chama de sentença mandamental, nomenclatura essa que é adotada no presente trabalho ${ }^{333}$. A sentença mandamental tem a característica de ordenar ao réu, sob uma cominação prevista no próprio comando judicial. Distingue-se nesse aspecto da sentença condenatória, que não ordena o pagamento da quantia reconhecidamente devida. A condenação não é uma ordem de cumprimento da obrigação; é o reconhecimento do débito, cujo inadimplemento ensejará a possibilidade de execução forçada. Tanto é assim que, quando o réu cumpre a obrigação reconhecida na sentença antes de ser executado, fala-se em cumprimento “espontâneo" da sentença ${ }^{334}$.

A sentença mandamental seria, portanto, uma quarta espécie na classificação das sentenças, e teria a característica de ordenar ao réu um comportamento sob cominação de multa ou outro meio de coerção. Isto é, a sentença mandamental tem sua força na coerção indireta sobre a vontade do obrigado; o réu cumpre a ordem judicial para evitar o mal que lhe seria causado caso a descumprisse ${ }^{335}$.

Nesse sentido atua a decisão que determina ao empregador, sob pena de multa diária por descumprimento da ordem, que não aplique sanções humilhantes a empregados que descumpram metas de produtividade; que suspenda procedimentos abusivos adotados por determinado gerente ou chefe de setor; que restabeleça a rotina de um empregado colocado indevidamente em ócio forçado, entre outros casos. A sentença mandamental é a que melhor opera a eficácia da tutela inibitória.

A classificação das sentenças que reconhece a sentença mandamental é chamada de classificação quinária (em oposição à tradicional classificação trinária), pois são estabelecidas cinco espécies de sentenças: além das três espécies tradicionais

\footnotetext{
${ }^{333}$ Sobre a origem da definição de sentença mandamental e as mudanças ocorridas em relação à sua ideia original, vide MOREIRA, José Carlos Barbosa. A sentença mandamental: da Alemanha ao Brasil. Revista de Processo. São Paulo, ano 25, n. 97, pp. 251-264, jan/mar 2000.

${ }^{334}$ BEBBER, 2007, p. 71.

335 "A mandamentalidade não está na ordem, ou no mandado, mas na ordem conjugada à força que se empresta à sentença, admitindo-se o uso de medidas de coerção para forçar o devedor a adimplir. Só há sentido na ordem quando a ela se empresta força coercitiva; caso contrário, a ordem é mera declaração. [...] a ordem, quando dirigida ao devedor, determina o adimplemento sob pena de um mal, enquanto a sentença condenatória não traz gravame algum no caso de não ser voluntariamente observada" (MARINONI, 2012, p. 337 , grifos do original).
} 
(declaratórias, constitutivas e condenatórias), a mandamental e a executiva (às vezes denominada executiva lato sensu) ${ }^{336}$.

Enquanto a sentença mandamental ordena ao réu, agindo por coerção indireta sobre sua vontade (meios indiretos de coerção), a sentença chamada de executiva alcança, ela própria (isto é, diretamente), a satisfação do direito material, independentemente da vontade do réu. Ocorre em casos como a busca e apreensão, remoção de pessoas e coisas, desfazimento de obras e impedimento de atividade nociva, nos exatos termos do $\S 5^{\circ}$ do art. 461 do CPC, o qual autoriza expressamente o uso de força policial, se necessário.

Tomando-se como exemplo a necessidade de manutenção do meio ambiente do trabalho sadio e equilibrado, em uma fábrica onde poluentes sejam liberados no ambiente em prejuízo da saúde dos trabalhadores, há mais de uma forma de alcançar a tutela efetiva do direito material. Pode-se ordenar ao empregador, sob pena de multa, a instalação de equipamento de proteção coletiva, que neutralize os efeitos da poluição no ambiente. Pode-se, de outro lado, interditar o funcionamento da fábrica até a comprovação de que a poluição ambiental cessou. No primeiro provimento exemplificado, tem-se uma tutela inibitória em sentença mandamental; no segundo exemplo, uma tutela inibitória em sentença executiva. Ambas com fundamento no art. 461 do CPC ou no art. 84 do CDC, conforme se esteja diante de processo individual ou coletivo.

É a necessidade de cada caso concreto que ditará a conveniência de agir com coerção indireta sobre a vontade do réu (sentença mandamental) ou de impor medida executiva direta sobre a esfera jurídica deste (sentença executiva), observado o princípio da necessidade, do qual se tratará adiante.

O que é necessário perceber, porém, é que o tratamento de conflitos trabalhistas relativos a assédio moral (entre outros) nos estreitos limites da ação condenatória não atende às necessidades materiais e de tutela efetiva dos direitos, do ponto

\footnotetext{
${ }^{336}$ BEBBER, Júlio César. O cumprimento da sentença no processo do trabalho. 2 ed. São Paulo: LTr, 2007, p. 30-31.
} 
de vista do direito fundamental de ação ${ }^{337}$. A sentença condenatória no processo do trabalho, passível apenas de execução forçada, tem sido uma forma de autorizar a expropriação de direitos fundamentais de trabalhadores mediante o pagamento de valores pecuniários $^{338}$; e, na medida em que se compreende o fenômeno do assédio moral como violação à dignidade humana, esse procedimento deve ser modificado com urgência, na linha do que já foi exposto acima. Daí a importância de o processo do trabalho passar a privilegiar as sentenças mandamentais e executivas, em especial para a proteção dos trabalhadores em face de condutas de assédio moral.

A tutela inibitória e o sistema das sentenças mandamentais e executivas afastam o princípio da tipicidade das formas executivas ${ }^{339}$. Por tal princípio entende-se a limitação da atuação do Judiciário, na execução, aos meios e às formas que estejam expressamente previstas em lei, na ordem procedimental que também a lei regula. $O$ princípio da tipicidade exclui a criatividade do juiz da execução na busca por efetividade. Cita-se o devedor, penhoram-se bens, avaliam-se os bens, discutem-se as matérias arguidas pelo devedor em embargos à execução, realiza-se praça pública dos bens, etc. A observância estrita do rito legal da execução é uma exigência do princípio da tipicidade.

No sistema da tutela inibitória, contudo, o princípio da tipicidade não vigora. Como se viu, não só a ordem sob pena de multa diária pode ser manejada pelo juiz; outros meios de execução podem ser privilegiados na busca da efetividade da tutela jurisdicional - aliás, é expresso o $\S 5^{\circ}$ do art. 461 do CPC ao dizer que o juiz poderá, "de ofício ou a

\footnotetext{
${ }^{337}$ Até porque "admitir a tutela ressarcitória, no caso de direitos não patrimoniais, é o mesmo que aceitar que o processo, em vez de servir à efetiva tutela do direito, somente pode condenar o violador a pagar por algo que não tem preço." (MARINONI, 2012, p. 139).

${ }^{338}$ MARINONI emite crítica contundente ao sistema da sentença condenatória no processo do trabalho, que merece transcrição: "Na verdade, a execução por expropriação, na Justiça do Trabalho, é um verdadeiro entrave não só à promessa constitucional de duração razoável do processo, como também à própria tutela do direito ao sustento do trabalhador. Tal procedimento somente serve para incentivar os que têm dinheiro a não pagar pontualmente. Sabe-se, em uma visão de mercado, que é muito melhor esperar para pagar depois de finalizado o procedimento (visto como autônomo ou como fase, tanto faz) de execução por expropriação, uma vez que o dinheiro, neste período de tempo, certamente dá frutos àquele que tem o tempo ao seu favor. Ademais, a demora também é utilizada pelo executado para vencer as resistências do exequente e, assim, para fazer gerar um acordo em que o trabalhador abre mão de parte do direito em troca da lentidão da justiça. Aí o devedor é mais uma vez beneficiado em prejuízo do credor; a diferença é a de que, no caso de 'acordo', lança-se ao demandante o imoral argumento de que a 'justiça é demorada', como se isto fosse um problema de quem é obrigado a ir a juízo e não de quem tem o dever de remediá-la." (2012, p. 349).
}

${ }^{339}$ MARINONI, 2012, p. 192. 
requerimento, determinar as medidas necessárias, tais como" as que são exemplificadas no mesmo dispositivo.

Se, em determinado caso concreto, o magistrado verificar que a imposição de multa ao réu não é eficaz para conduzi-lo ao cumprimento do comando judicial, é possível ao juiz adotar outra medida executiva, que se mostre, nessa hipótese, mais adequada. E pode não ser uma das medidas que o legislador exemplificou. Pode ser, até mesmo, a interdição do estabelecimento do empregador, em última análise ${ }^{340}$.

O que importa verificar e ter com clareza é que o legislador dotou o juiz de poderes executivos atípicos ${ }^{341}$. Poderes que o juiz deve usar no sentido da busca de eficácia da tutela jurisdicional. A mera execução por expropriação, no sistema da sentença condenatória, já se mostrou insuficiente em várias situações substanciais que não admitem apenas a conversão do direito em pecúnia para pagamento depois de muitos anos da violação.

Assim sendo, a concentração de poderes executivos nas mãos do juiz implica o reconhecimento de outro princípio, que visa a legitimar o uso desses mesmos poderes: o princípio da necessidade. Trata-se do uso dos poderes executivos do juiz na exata medida da necessidade para a tutela do direito, sem que haja excessos ilegítimos de restrição ao patrimônio jurídico do réu ${ }^{342}$.

\footnotetext{
340 "Parece claro, aliás, que, a depender da verossimilhança da alegação, e sempre a critério da autoridade judiciária, a interdição ou o embargo liminar estará permitido a qualquer tempo, mesmo à míngua de laudo preliminar e antes de qualquer audiência de justificação prévia. A grandeza do direito ameaçado determinará, via de regra, a concessão da tutela inibitória preventiva, concedendo-se imediata concreção aos princípios ambientais já referidos (em especial os da prevenção e da precaução)." (FELICIANO, 2011, p. 157, com grifos no original).
}

341 “É que em sede de tutela inibitória vigora o princípio da não identificação, ou da atipicidade, inexistindo taxatividade quanto às medidas cabíveis na busca pela efetividade de direitos. Daí a reaproximação entre direito material e processo, revelando um movimento neossincretista da teoria da ação." (FABRE e LAVEZO, 2010, p. 5937).

342 Até porque, como pondera Carlos Alberto Álvaro de OLIVEIRA, "[a] efetividade e a segurança apresentam-se como valores essenciais para a conformação do processo em tal ou qual direção, com vistas a satisfazer determinadas finalidades, servindo também para orientar o juiz na aplicação das regras e princípios. Poder-se-ia dizer, numa perspectiva deontológica, tratar-se de sobreprincípios, embora sejam, a sua vez, também instrumentais em relação ao fim último do processo, que é a realização da Justiça do caso. Interessante é que ambos se encontram em permanente conflito, numa relação proporcional, pois quanto maior a efetividade menor a segurança, e vice-versa. Assim, por exemplo, o exercício do direito de defesa, garantia ligada à segurança, não pode ser excessivo nem desarrazoado. Nos casos não resolvidos pela norma, caberá ao órgão judicial, com emprego das técnicas hermenêuticas adequadas, ponderar qual dos valores 
MARINONI fala em adequação dos meios executivos, em uso de meio idôneo e, ainda, em menor restrição possível a ser causada ao réu, para sedimentar a ideia da necessidade. Não é diferente da aplicação da própria regra da proporcionalidade: a restrição imposta ao direito do réu deve ser adequada, necessária e proporcional para que se legitime juridicamente ${ }^{343}$.

Essa legitimação da atuação judicial vem, porém, exposta na fundamentação da decisão que maneja os meios executivos para a tutela jurisdicional. É por meio da fundamentação da decisão que o juiz demonstra à sociedade a adequação da providência e sua necessidade para a proteção do direito em jogo; demonstra que a providência escolhida é aquela que, dentre as que protegem de maneira eficaz o direito do autor, menos agride a situação jurídica do réu. Aí reside a legitimidade dos poderes executivos judiciários ${ }^{344}$.

Quanto aos meios executivos propriamente ditos, cumpre mencionar com destaque a fixação da multa coercitiva, derivada das astreintes do direito francês. Trata-se

deverá prevalecer. Na verdade, garantismo e eficiência devem ser postos em relação de adequada proporcionalidade, por meio de uma delicada escolha dos fins a atingir." ( $O$ formalismo valorativo no confronto com o formalismo excessivo. PPGD-UFRGS, 2001, p. 4. Disponível em: http://www.ufrgs.br/ppgd/doutrina/CAO O Formalismo-valorativo no confronto com o Formalismo excessivo 290808.htm. Acesso em 30.3.2013.

${ }^{343}$ No mesmo sentido, quanto aos princípios do meio mais idôneo, menor restrição e proporcionalidade, o entendimento de FELICIANO (2011, p. 153).

344 “O poder de escolha, se é fundamental para o adequado exercício do poder, e é orientado pelas ideias de 'adequação', de 'meio idôneo' e de 'menor restrição possível', é legitimado pela necessidade de justificativa, vale dizer, de explicação das razões de escolha. Como se vê, esta forma de viabilizar o exercício do poder e, ao mesmo tempo controlá-lo, é fundamental em face dos direitos da sociedade contemporânea, e constitui pura manifestação da crescente necessidade de se pensar o direito para o caso concreto." (MARINONI, 2012, p. 203). Não se pode olvidar, outrossim, que o "juiz recebe do povo, através da Constituição, a legitimação formal de suas decisões, que muitas vezes afetam de modo extremamente grave a liberdade, a situação familiar, o patrimônio, a convivência na sociedade e toda uma gama de interesses fundamentais de uma ou de muitas pessoas. Essa legitimação deve ser permanentemente complementada pelo povo, o que só ocorre quando, segundo a convicção predominante, os juízes estão cumprindo seu papel constitucional, protegendo eficazmente os direitos e decidindo com justiça.” (DALLARI, 2007, p. 91).

"Sob pena de serem acusadas de puramente arbitrárias e ilegítimas em um estado democrático de direito, as escolhas do intérprete nesse ambiente demandam justificativas." (BARCELLOS, 2005, p. 39-40). "O juiz exerce poder político ao desempenhar uma das atividades próprias do Estado: a jurisdição. É, portanto, um agente delegado da sociedade, a quem deve contas de sua atuação. Note-se que a decisão judicial não é mero conselho: ela poderá ser imposta pela força ao jurisdicionado, se necessário, em uma manifestação típica do poder de império estatal. Parece evidente que o cidadão tem o direito de saber por que um seu agente delegado decidiu em determinado sentido e não em outro." (ibidem, p. 46).

A "fundamentação judicial é, ao lado do contraditório, a maior garantia dos cidadãos perante o Poder Judiciário nos Estados Democráticos de Direito.” (FELICIANO, 2011b, p. 40). 
do meio executivo em geral mais adequado à operacionalização da tutela inibitória ${ }^{345}$, e por isso o que tem mais incidência prática.

A multa coercitiva, como sugere a expressão, tem natureza de meio de coerção indireta sobre a vontade do réu, de modo a fazê-lo cumprir o provimento jurisdicional ${ }^{346}$. Nota-se, então, serem distintas a multa fixada para alcance de tutela específica e a indenização por perdas e danos. Esta, como se sabe, visa a reparar o prejuízo causado pela violação do direito; a multa, pelo contrário, quando usada no bojo de uma ação inibitória, tem a função justamente de impedir a violação do direito, já que induz o réu a observar o comando judicial, que veicula a tutela inibitória.

Tendo naturezas jurídicas distintas, não se pode sustentar a compensação da multa com a indenização (quando houver indenização ${ }^{347}$ ). Uma coisa não tem nada a ver com outra; a incidência da multa coercitiva não implica o "início" do pagamento da indenização dos prejuízos que eventualmente tenham sido causados ao autor e titular do direito. A cumulação da multa com a indenização eventualmente cabível não somente é recomendável, como se apresenta como decorrência necessária do sistema. Além do mais, a força coercitiva da multa seria bastante reduzida se o devedor de antemão soubesse que o valor da multa seria deduzido de eventual indenização a cujo pagamento fosse futuramente condenado. Seria um contrassenso, quase um estímulo à violação do direito.

\footnotetext{
345 “O meio mais usual com que a jurisdição atua sobre a vontade do Réu, na tutela inibitória veiculada por ação civil pública trabalhista, é através da cominação de multas, ora diárias (astreintes), ora fixas, ora fixas e multiplicadas pelo número de trabalhadores lesados, ora multiplicadas pelo número de obrigações descumpridas, multas estas que podem incidir sobre qualquer tipo de obrigação de fazer ou não-fazer, sem restrição legal para que se limitem a obrigações infungíveis." (FABRE e LAVEZO, 2010, p. 5938).

${ }^{346}$ Nesse sentido, Rodolfo de Camargo MANCUSO, ao tratar da sentença, proferida em ação civil pública, que comina multa coercitiva, ressalta que "sua carga impositiva sobre o devedor deve ser idônea a produzir em seu animus o estímulo suficiente para que ele opte pela prestação específica, em vez de pagar a multa diária: normalmente, para se obter esse efeito, bastará que o ônus financeiro representado pelo reiterado pagamento da astreinte se revele mais oneroso do que o cumprimento do julgado" (Ação civil pública: em defesa do meio ambiente, do patrimônio cultural e dos consumidores. 10 ed. São Paulo: Editora RT, 2007, p. 268).

347 "Importa perceber que a astreinte tem por fim forçar o réu a adimplir, enquanto o ressarcimento diz respeito ao dano. É evidente que a multa não tem qualquer relação com o dano, até porque, como acontece na tutela inibitória, pode não haver dano a ser indenizado." (MARINONI, 2012, p. 182-183). Cf. também MANCUSO, 2007, p. 271-272.
} 
Como consequência da distinção em relação à indenização de prejuízos, a multa coercitiva não será limitada ao valor da obrigação. Em outros termos, se houver um valor que antecipadamente se saiba seja o equivalente pecuniário do direito discutido, tal valor não deve ser considerado o limite máximo para a fixação da multa coercitiva em tutela inibitória ${ }^{348}$. Com efeito, também essa limitação seria contraditória, pois o réu entenderia que não teria nada a perder senão o fato de ressarcir o prejuízo entendido como equivalente ao direito cuja violação se quer evitar.

O argumento de aplicação do limite previsto no art. 412 do Código Civil não deve ser acolhido. Tal norma se insere no campo da regulamentação dos contratos, isto é, dos negócios jurídicos privados, e não no campo da eficácia de provimentos jurisdicionais mandamentais. Não há razão para aplicação da regra do art. 412 do CC no âmbito processual da tutela inibitória, até porque nesta vigora a regra da atipicidade dos meios executivos.

Quanto aos critérios de arbitramento da multa coercitiva, o legislador, coerentemente, silenciou. Incumbiu o juiz da tarefa de analisar, com base nas características do caso concreto, a medida da eficácia da multa e, com isso, fixar-lhe o valor mais adequado para cada caso. Fez bem o legislador. A multa deve ser compatível com a capacidade financeira do réu, isto é, não faz sentido uma multa de valor baixo para uma grande empresa multinacional, e é desnecessária - e, portanto, ilegítima - uma multa de valor alto demais em desfavor de uma pequena empresa familiar. É o juiz da causa, sensível às nuances de cada caso, quem melhores condições possui de arbitrar a multa em valor adequado.

Um instrumento adicional de eficácia da multa coercitiva é o aumento progressivo do seu valor. O juiz pode prever, por exemplo, uma multa de cem reais por dia de atraso no cumprimento da ordem; se o atraso ultrapassar cinco dias, a multa passa a ser de duzentos reais por dia, e se ultrapassar dez dias, ela passa a ser de trezentos reais por dia de atraso. Levando em consideração a capacidade de resistência que pode existir em razão

${ }^{348}$ MARINONI, 2012, p. 185; FABRE e LAVEZO, 2010, p. 5938. 
da solidez financeira do réu, tem-se aí uma forma de fazê-lo vulnerável à coerção e, com isso, dirigir sua vontade ao cumprimento da ordem judicial ${ }^{349}$.

Quanto ao momento da efetiva cobrança da multa coercitiva, existe um dissenso acerca da necessidade do trânsito em julgado da decisão. Tendo em vista a função coercitiva, de ameaça, para que o réu direcione sua vontade ao cumprimento da obrigação imposta pela decisão, MARINONI sustenta que a exigibilidade de pagamento da multa só ocorre com o trânsito em julgado. A coerção do réu ocorreria com a possibilidade de cobrança futura da multa, tão-somente ${ }^{350}$.

Outra discussão no regime da multa coercitiva se dá com sua imposição em decisão antecipada não confirmada pela sentença, isto é, quando a sentença é de improcedência. Nessa questão entram em jogo as formas de ver a multa coercitiva, ora como mecanismo que favorece o autor com a quantia derivada do descumprimento do réu, ora como verdadeiro instrumento de dignidade da jurisdição.

MARINONI, tendo em vista que a multa é destinada ao autor da ação, não concorda que ela seja cobrada do réu quando a sentença vem a rejeitar o pedido formulado pelo primeiro. Entende ele que "se o nosso sistema confere ao autor o produto da multa, é completamente irracional admitir que o autor possa ser beneficiado quando a própria jurisdição chega à conclusão de que ele não possui o direito que afirmou estar presente ao executar (provisoriamente) a sentença ou a tutela antecipatória"351.

Entretanto, o problema parece exigir uma análise da perspectiva da efetividade da jurisdição. Ora, se o Estado impôs ao réu um comportamento sob pena de incidência de

\footnotetext{
349 "Dada a finalidade da multa e a possibilidade - que é inerente a sua utilização - de o devedor resistir à pressão que ela tem por fim exercer, é até mesmo aconselhável que o juiz fixe uma multa que aumente progressivamente com o passar do tempo. O fluir do tempo sem o adimplemento do réu evidencia sua capacidade de resistência, e se o objetivo da multa é justamente quebrar esse poder de resistir, nada mais natural do que sua fixação em caráter progressivo." (MARINONI, 2012, p. 186).

350 "O que importa, em outras palavras, quando se pensa na finalidade coercitiva da multa, é a ameaça de o réu ter que futuramente arcar com ela. Com efeito, é importante deixar claro que a multa cumpre seu papel através da ameaça que exerce sobre o réu; a multa, para exercer sua finalidade coercitiva, não precisa ser cobrada antes do trânsito em julgado. A finalidade coercitiva não se relaciona com a cobrança imediata da multa, mas apenas com a possibilidade de sua cobrança futura; essa possibilidade é suficiente para atemorizar o demandado e, assim, convencê-lo a adimplir." (ibidem, p. 190-191).

${ }^{351}$ Ibidem, p. 190.
} 
multa, o não cumprimento da ordem implicaria desobediência fundada na própria razão, a qual evidentemente pode ou não prevalecer no julgamento final, mas não deixa de ser decorrente de visão subjetiva. Assim, por essa visão, a multa imposta antecipadamente seria condicionada (à confirmação pela sentença), e isso de certa forma poderia reduzir sua força coercitiva ${ }^{352}$.

Uma solução para o impasse seria executar a multa devida, independentemente da sentença de improcedência, mas em tal hipótese destinar o valor decorrente ao Estado ou a um fundo de interesse coletivo ${ }^{353}$, e não ao autor da ação - que, afinal, decidiu-se não ser o titular do direito que alegou no processo.

Embora com menos frequência, a tutela inibitória também pode ser em alguns casos operacionalizada por um provimento de natureza executiva. Na sentença executiva, como se disse antes, a satisfação do direito não depende da vontade do réu, a qual não é indiretamente influenciada por um meio de coerção. O provimento executivo dispõe diretamente sobre o ato concreto que será praticado para a adequada proteção do direito do autor, e o ato será praticado pelo próprio Estado, seja por oficial de justiça, seja pela polícia ou outro agente público.

Suponha-se o assédio moral praticado em reuniões periódicas, nas quais um superior hierárquico divulga a produtividade dos trabalhadores e, em seguida, aplica advertências constrangedoras aos menos produtivos, acompanhadas de "castigos" humilhantes no afã de estimular o rendimento no próximo período. Nessa situação, postulada uma tutela inibitória, o juiz pode se convencer de que mais adequada do que a imposição de multa ao réu seja a intervenção direta no estabelecimento, no momento da

352 Nesse sentido o entendimento de Paulo Ricardo POZZOLO: “A multa [...] é, no entanto, devida independentemente do resultado de mérito do processo, pois se trata de instrumento processual destinado ao cumprimento das ordens judiciais.” (Ação inibitória no processo do trabalho. São Paulo: LTr, 2001, p. 167). É no mesmo sentido a opinião de Priscila Lopes PONTINHA (2009, p. 213).

\footnotetext{
353 "No direito brasileiro, tais multas cominatórias revertem-se em favor do Autor. No caso das ações civis públicas trabalhistas, a tendência é a reversão ao Fundo de Amparo ao Trabalhador, criado pelo art. 10 da Lei 7.998/90 e em sintonia com o art. 13 da Lei 7.347/85, embora não se trate exatamente de um fundo específico de recomposição dos direitos lesados de que cuida esta lei e tampouco conte com a composição na forma por ela discriminada. Daí, portanto, a conveniência, notadamente em casos afetos a interesses de jovens, de reversão ao Fundo de Direitos da Criança e do Adolescente (FIA), ou a conversão dos valores em obrigações relacionadas aos direitos lesados, como a conversão em obrigação de elaborar cartilhas informativas, entregar bens a entidades beneficentes ou a órgãos de fiscalização do trabalho (computadores, veículos, etc.), ou até mesmo, de construir escolas e postos de saúde, como se dá quando as multas assumem patamares mais elevados (e que é comum em hipóteses de trabalho escravo)." (FABRE e LAVEZO, 2010, p. 5938).
} 
reunião, para que as condutas ilícitas não sejam praticadas. A ordem seria que o oficial de justiça comparecesse no local e cancelasse a reunião, ou mesmo que impusesse imediatamente a cessação das condutas tidas por ilícitas na decisão judicial.

Assim, reafirma-se que a tutela inibitória deve ser operada por meio da sentença mandamental ou da sentença executiva, tendo em vista as características do caso concreto, cuidadosamente analisadas e sopesadas pelo juiz da causa.

\subsection{Legitimação processual}

O intuito deste tópico é o de delinear as pessoas que devem estar nos polos da ação inibitória, isto é, quem tem legitimação para agir (no polo ativo), da perspectiva individual e da perspectiva coletiva, e também quem é naturalmente o réu a compor o polo passivo do mesmo processo.

Em primeiro lugar, a legitimação ativa da ação individual é, evidentemente, do trabalhador que em tese encontra-se na iminência de sofrer a conduta de assédio moral. $\mathrm{O}$ primeiro legitimado para agir é o próprio empregado que teme ser alvo da violência psicológica. Da mesma forma, se alguns trabalhadores temem a conduta patronal, a ação inibitória pode ser proposta por eles em regime de litisconsórcio ativo (a chamada ação plúrima), sem desnaturar seu caráter de ação individual.

É preciso, porém, reconhecer a dificuldade de exercício da pretensão individual à tutela inibitória pelo próprio trabalhador ameaçado. No Brasil, aliás, já é rara a propositura de ação trabalhista condenatória pelo empregado durante a vigência da relação de emprego, pois os postos de trabalho do país são cada vez mais precários e instáveis. O temor de perda do emprego posterga a maioria das lides trabalhistas para depois da dissolução do contrato de trabalho. Que se dirá, então, de uma ação que nem mesmo é condenatória, mas sim mandamental inibitória, de conteúdo preventivo, voltado ao futuro. Beira a utopia pensar que os empregados exercerão livremente o direito de ação para postular provimentos preventivos da prática de assédio moral, durante a vigência do contrato de trabalho. 
A depender, pois, do exercício individual do direito de ação pelo próprio trabalhador ameaçado, a tutela inibitória de assédio moral existirá apenas e tão-somente em discussões acadêmicas, e não transbordará para a vida prática.

Entretanto, o ordenamento jurídico possui alternativas para viabilizar o exercício do direito de forma plausível. Uma delas é a chamada substituição processual do trabalhador ameaçado pelo sindicato da categoria profissional, nos moldes do art. $6^{\circ}$ do Código de Processo Civil e do inciso III do art. $8^{\circ}$ da Constituição Federal. Se um ou alguns trabalhadores se veem ameaçados de sofrer assédio moral na empresa, pode o sindicato de classe propor a ação inibitória, em nome próprio, em favor dos trabalhadores.

Não importa que seja apenas um trabalhador afetado na situação concreta; isso não afasta a legitimação do sindicato. Primeiro, porque o permissivo da regra constitucional não exige que o direito seja coletivo para que a entidade sindical possa defendê-lo em juízo; segundo, porque como já visto antes a interpretação mais adequada que se faz do assédio moral na relação de emprego é a de que ele é um fenômeno coletivo, em essência.

Com efeito, assentou-se que o assédio moral é uma forma de poluição do meio ambiente do trabalho, uma poluição ambiental psicológica. Degrada e desequilibra o meio ambiente do trabalho de forma geral, ainda que as agressões psíquicas sejam dirigidas exclusivamente a um empregado da empresa. Tal poluição ambiental afeta o bem estar de todos os empregados que partilham do mesmo ambiente, de maneira que torna evidente que todos, e cada um deles, têm o direito de exigir que cesse a poluição causada pelo assédio moral.

No exemplo já citado do ranking dos empregados com base em produtividade individual, com aplicação de penalidade humilhante ao último colocado na apuração, pouco importa que o último colocado seja sempre um empregado determinado. Não apenas ele sofre (embora seu sofrimento seja maior) as consequências da degradação do ambiente pelo assédio moral: todos os trabalhadores se veem premidos pela necessidade de produzir mais e mais, de modo a se proteger das humilhações, o que gera um estado permanente de tensão psicológica que inclusive favorece, como se sabe, o surgimento de doenças 
ocupacionais. O direito ao meio ambiente do trabalho sadio é afetado, e por isso a legitimação para postular a tutela inibitória é coletiva, não meramente individual.

Daí por que não se deve afastar a legitimação dos sindicatos profissionais para a ação inibitória de assédio moral, mesmo que seja indicado como vítima direta da conduta da empresa apenas um dos empregados. Em tais hipóteses, o direito subjacente à pretensão é o direito coletivo, ou mesmo difuso, de manutenção do meio ambiente do trabalho sadio e equilibrado.

Note-se que a substituição processual pelo sindicato, com indicação dos nomes dos empregados substituídos individualmente, já perde um pouco da eficácia da ação, em comparação com a defesa dos direitos na perspectiva coletiva. É que a indicação de nomes de empregados na petição inicial pode acarretar a intimidação individual desses trabalhadores, com ameaças de desemprego ou outras represálias, de maneira a desestimular o sucesso da ação inibitória. É visível, portanto, que a interpretação mais adequada, que mais privilegia o direito fundamental de ação e a proteção do meio ambiente do trabalho, é a que outorga a legitimação coletiva para a ação inibitória de assédio moral, de forma ampla, sem necessidade de nomeação de empregados diretamente interessados na petição inicial.

Além dos sindicatos das categorias profissionais, cabe também, certamente, a atuação do Ministério Público do Trabalho na defesa de interesses difusos e coletivos dos trabalhadores, em especial na perspectiva do direito ao meio ambiente do trabalho sadio e equilibrado. E aqui não se deve entrar em discussões envolvendo a legitimidade do parquet para a defesa de direitos individuais homogêneos dos trabalhadores, pois como se viu a tutela inibitória de assédio moral não tem conteúdo de direito individual apenas: antes de tudo, trata-se de direito coletivo, para cuja defesa a legitimidade do MPT não é posta em dúvida $^{354}$.

Em suma, a legitimação ativa da ação inibitória de assédio moral deve ser acolhida de forma ampla, para possibilitar seu exercício não apenas pelo trabalhador

354 “O Ministério Público do Trabalho [...] tem exigido meio ambiente do trabalho adequado nas instalações das empresas, de forma a prevenir os riscos de acidentes com o trabalho perigoso, penoso e insalubre." (LEITE, Carlos Henrique Bezerra. Ministério Público do Trabalho. 3 ed. São Paulo: LTr, 2006, p. 172-173). Cf. também MORAES, M. M. L., 2002, p. 138. 
diretamente envolvido, ou por alguns trabalhadores diretamente envolvidos, mas também e sobretudo para possibilitar o exercício da ação coletiva a ser proposta pelos sindicatos profissionais ou pelo Ministério Público do Trabalho, em defesa do direito ao meio ambiente do trabalho sadio e equilibrado.

A legitimação passiva da ação inibitória é, naturalmente, do empregador. Isso por mais de um motivo. Primeiro, porque na maioria dos casos é o empregador, pessoalmente ou por seus prepostos, que pratica de fato o assédio moral na relação de emprego. Faz sentido que a ordem para inibição da conduta ilícita seja a ele direcionada. Em segundo lugar, é o empregador a pessoa dotada de poder privado no interior dessa relação, de maneira que ele pode suspender e evitar atos de prepostos seus, ainda que supostamente praticados ou em via de ser praticados sem seu prévio conhecimento. Em terceiro lugar, o empregador é obrigado a manter o meio ambiente do trabalho sadio e equilibrado, o que, como foi dito em mais de uma oportunidade, abrange também a perspectiva da saúde psíquica dos empregados. Assim, mesmo que se trate de assédio moral horizontal, por exemplo, sendo inadmissível a omissão patronal, ao empregador deve dirigir-se o mandamento judicial inibitório do assédio, de modo a fazê-lo agir no sentido da prevenção.

A legitimação passiva típica do empregador não deve excluir, de outro lado, a legitimação concorrente da pessoa diretamente indicada como assediadora. É possível, então, por exemplo, que ao lado da empresa empregadora esteja no polo passivo, como litisconsorte, o gerente ou diretor do estabelecimento em que supostamente ocorre ou ocorrerá o assédio moral.

Esse litisconsórcio passivo deve ser admitido, seja em razão da pertinência à lide do suposto assediador (que poderá assim exercer defesa própria), seja por dotar de maior eficácia o provimento mandamental, pois a ordem do juiz será dirigida não apenas à empresa, mas também à pessoa do gerente ou diretor, que invariavelmente terá menor capacidade de resistência ao mandamento judicial e, como consequência, mais probabilidade de obediência. 


\subsection{Peculiaridades da causa de pedir e da prova na ação inibitória}

Um dos requisitos da petição inicial é a causa de pedir, isto é, os fundamentos da demanda posta em juízo pelo autor, a razão de postular; na linguagem do Código de Processo Civil, a descrição do fato e dos fundamentos jurídicos do pedido (art. 282, inciso III) ${ }^{355}$. A causa de pedir é um dos elementos da ação, isto é, compõe a tríplice identidade ${ }^{356}$ (juntamente com as partes e o pedido) que define uma ação judicial e a diferencia de outras. Vê-se, então, a importância da causa de pedir para, por exemplo, delimitar os efeitos da coisa julgada.

A linguagem da Consolidação das Leis do Trabalho é sensivelmente diferente daquela do CPC, no tocante à exigência de indicação da causa de pedir. O art. 840 da CLT, em seu $\S 1^{\circ}$, prevê que a petição inicial trará uma "breve exposição dos fatos de que resulte o litígio", e a doutrina tem interpretado esse dispositivo como uma exigência menos rigorosa do que a contida no art. 282 do CPC. Daí a conclusão de que a petição inicial no processo do trabalho não precisa observar tantas formalidades para a aptidão, em comparação com a petição inicial do processo civil.

Dito isso, e voltando os olhos ao tema da ação inibitória, é preciso que haja na petição inicial uma descrição da conduta temida e que se pretende evitar (inibir). A alegação genérica de prática de assédio moral não é suficiente ${ }^{357}$, até porque a proibição geral do assédio moral, a ilicitude em tese, independe de provimento judicial específico. $\mathrm{O}$ autor deve trazer ao processo a descrição da conduta que quer ver proibida pela sentença, pois é sobre essa conduta descrita que incidirá o juízo de ilicitude, para a conclusão acerca do cabimento da tutela inibitória.

\footnotetext{
${ }^{355}$ Em uma síntese clara e objetiva, José Carlos Barbosa MOREIRA ensina que "todo pedido tem uma causa. Identificar a causa petendi é responder à pergunta: por que o autor pede tal providência? Ou, em outras palavras: qual o fundamento de sua pretensão?" ( $O$ novo processo civil brasileiro. 22 ed. Rio de Janeiro: Forense, 2002, p. 15).

${ }^{356}$ CINTRA, GRINOVER e DINAMARCO, 1994, p. 258.

357 "É necessário, na causa de pedir, especificar os fatos pelos quais se considera que se configure o risco de lesão e formular pretensão específica que seja eficaz para evitar o dano." (SOUTO MAIOR, 2005, p. 218).
} 
A petição inicial da ação inibitória deve trazer, também, os motivos do temor do autor em relação à conduta descrita. Com efeito, seria discutível a presença do interesse de agir em um processo no qual não se demonstra a razão que leva o autor a temer a conduta que alega. Em outras palavras, a mera suspeita de que o empregador venha a praticar uma conduta assediante não dá azo à ação inibitória; é preciso que se demonstre a plausibilidade do temor da prática da referida conduta, e essa plausibilidade compõe a causa de pedir da ação inibitória. É a probabilidade da prática do ato ilícito, fundada em razões devidamente expostas, que preenche esse requisito da ação ${ }^{358}$.

É possível o ajuizamento da ação inibitória para impedir o empregador de relegar o empregado ao ócio forçado, após o retorno de uma licença médica por acidente do trabalho ou doença ocupacional, para pressioná-lo a demitir-se ${ }^{359}$. A conduta patronal a inibir está delimitada, e a plausibilidade do temor do autor será demonstrada, por exemplo, se indicados outros casos similares que ocorreram com colegas de trabalho na mesma situação. Torna-se plausível admitir que o empregador repita seu próprio comportamento do passado.

Deve-se salientar, ademais, que, na esteira da distinção efetuada anteriormente $^{360}$, não deve compor a causa de pedir da petição inicial de ação inibitória a argumentação pertinente ao dano que se possa esperar da conduta temida. A tutela inibitória, repita-se, versa sobre o ilícito e não sobre o dano; a intenção é evitar a prática do ilícito, o que de forma consequente e eventual evitará que se produza um dano ao autor.

Não se deve exigir da petição inicial, portanto, que descreva ou fundamente o temor de dano injusto a ser sofrido pelo autor. Basta a fundamentação pertinente ao ato ilícito que se pretende evitar. Essa abordagem objetiva da ação inibitória acarreta uma consequência positiva no que concerne ao tema da prevenção do assédio moral: a exclusão

\footnotetext{
${ }^{358}$ Para PONTINHA, “a ameaça justificadora do manejo da ação inibitória é aquela objetiva, permeada de atos preparatórios e contemporâneos que levem à conclusão de que a lesão ao direito está prestes a ser concretizada" (2009, p. 201).

${ }^{359}$ Trata-se de exemplo comum de conduta assediante de empregadores. Cf., por exemplo, MENEZES, 2010, p. 5 .

${ }^{360}$ Vide tópico 5.2, supra.
} 
da discussão árida que permeia a questão dos danos psíquicos e físicos que podem ser causados pela violência psicológica.

Com efeito, já se demonstrou a dificuldade de se comprovar cabalmente o nexo de causalidade entre atos praticados no meio ambiente do trabalho e doenças psíquicas que acometem os trabalhadores. Tal dificuldade, porém, se encerra nos processos que versem sobre a responsabilidade civil do empregador por esses danos. Não há que trazer esse tema aos processos relativos à tutela inibitória, a qual independe do dano concreto que a ilicitude possa provocar.

Assim, o tema dos danos não compõe a causa de pedir da ação inibitória e, consequentemente, não deve ser admitido na matéria probatória do processo. Por impertinência, deve então ser indeferido qualquer requerimento formulado no sentido da realização de provas que tenham por objeto o dano e sua probabilidade.

Pois bem. No tocante ao tema da prova na ação inibitória, além do fato de não ser admitida a prova pertinente ao dano, deve ser salientada a importância da chamada prova indiciária, uma vez que a prova direta será praticamente inviável ${ }^{361}$, por ser a tutela inibitória um provimento destinado a produzir efeitos futuros ${ }^{362}$.

\footnotetext{
${ }^{361}$ Aliás, o assédio moral em si acarreta uma grande dificuldade de prova, em razão de sua própria natureza. "A prova judicial da prática do assédio sexual e moral é de extrema dificuldade para a vítima, posto que, na maioria das vezes, o assediante, em manifesta conduta pusilânime, 'age às portas fechadas'. Mediante essa situação, o meio eficaz, disponível à vítima, geralmente é a gravação das conversas abusivas, devendo o julgador admiti-la sem maiores receios." (DALLEGRAVE NETO, 2008, p. 218). Também a doutrina de Alice Monteiro de BARROS (2009, p. 197-198) e MENEZES (2010, p. 8) é no sentido da importância da prova por indícios.

Por outro lado, cabe salientar a resistência de parte da jurisprudência: "Recurso ordinário. Assédio sexual. Por se tratar de acusação gravíssima, na medida em que tipificada como crime, previsto no art. 216-A do CP, imprescinde de prova cabal, robusta e inconteste dos fatos alegados. No caso dos autos, em que pese a dificuldade de se produzir provas, tanto pela reclamante quanto pela reclamada, como consignou o juízo $a$ quo, entendo, data vênia, que o ônus da prova compete à parte que alega, nos termos do art. 818 da CLT e 333, I, do CPC, mormente tratando-se de ato ilícito de tal gravidade, sendo temerária a condenação baseada tão somente em indícios ou probabilidade de veracidade do quanto alegado." (TRT/2 ${ }^{\mathrm{a}}$ Região. RO 00003356620125020018, $12^{\mathrm{a}}$ turma, Rel. Des. Benedito Valentini, DOE 21.9.2012).

${ }^{362}$ Em si mesma, a prova do assédio moral é essencialmente complexa e difícil. LOUSADA AROCHENA salienta que "[el] ajuste de la prueba del acoso moral con la doctrina general es especialmente intenso debido a la trascendental importancia de la prueba de indicios en la acreditación de un acoso moral, donde, por definición, el acosador pretende, con una finalidad perversa, la destrucción de la víctima. Como el componente intencional no se suele manifestar de manera directa, la prueba de indicios se erige habitualmente en la única forma de probar dicho elemento volitivo, de ahí, justamente, su trascendental importancia." (2002, p. 14).
} 
Pelo sistema da prova indiciária, a parte produz a prova de um fato (pretérito, evidentemente) que possibilite a conclusão, por um juízo de presunção, de que será no futuro praticado o fato temido pelo autor ${ }^{363}$. O fato pretérito que será demonstrado é o indício, ou fato indiciário, e ele não precisa ser descrito e especificado na petição inicial para que a prova seja admissível ${ }^{364}$. Como se disse, na petição inicial deve ser descrita a conduta temida, e os dados que exponham a plausibilidade desse temor. A partir do momento em que se pretenda provar indícios para convencer o juiz da procedência do pedido inibitório, a prova indiciária será admissível, na medida em que se mostre eficaz para a formação do convencimento judicial.

Voltando ao exemplo referido antes, se o autor pretende evitar que a empresa o coloque em ócio forçado, após retorno de licença médica, uma das formas de convencer o juiz da procedência do pedido é comprovar que a mesma empregadora já agira assim outras vezes, com empregados que estavam na mesma situação do autor (retorno de licença médica). Comprovados esses fatos indiciários, o juiz pode convencer-se, por presunção, de que é necessária a tutela inibitória para evitar o mesmo comportamento do empregador na situação do autor da ação. É a típica aplicação do sistema da prova indiciária.

Há que observar que a produção da prova na ação inibitória será mais difícil quando a intenção da parte for impedir a prática de um ato ilícito que não tenha sido praticado pelo réu anteriormente - a chamada tutela inibitória pura. Em tal hipótese, se exigirá mais do raciocínio do juiz para, a partir de indícios, concluir pelo cabimento ou não da inibitória. Se o mesmo exemplo do parágrafo anterior puder ser retomado, considerando-se, porém, que a empresa nunca tenha deixado em ócio forçado o empregado que retornasse de licença médica, outros fatos indiciários teriam de ser demonstrados, para possibilitar a presunção de que o ato ilícito provavelmente seria praticado pelo réu. Que fatos indiciários seriam esses é pergunta de difícil resposta, em abstrato, mas a depender do caso poderia o autor comprovar, por exemplo, que seu posto de trabalho já está ocupado por outro empregado contratado para a função por prazo indeterminado, ou então provar a existência de comentários feitos pelos superiores hierárquicos no ambiente de trabalho e presenciados por testemunhas.

${ }^{363}$ MARINONI, Luiz Guilherme. A prova na ação inibitória. Revista Jurídica Nota Dez. Porto Alegre, ano 50, número 294, abril/2002, p. 13.

${ }^{364}$ Ibidem, p. 13. 
Quando a ação inibitória visa a impedir a repetição ou a continuação do ilícito o uso da prova indiciária mostra-se, por outro lado, desde logo mais eficaz ${ }^{365}$, uma vez que a rigor é possível a prova da conduta anterior do réu, a autorizar o juízo de presunção de que tal conduta se repita ou se prolongue no tempo. Em tais casos, o ônus de prova que recai sobre o autor não é tão pesado, e o raciocínio presuntivo que deve ser feito pelo juiz não é tão complexo quanto na inibitória pura.

É preciso por fim enfatizar, na esteira da visão do processo do trabalho como instrumento de realização de direitos fundamentais ${ }^{366}$, a postura que se espera do magistrado na produção e apreciação da prova em ação inibitória. Consciente de seu papel na sociedade, na dignificação e concretização dos direitos, o juiz não deve se acomodar em função passiva e contemplativa do conjunto probatório; deve, ao contrário, manter conduta ativa na busca de seu próprio convencimento ${ }^{367}$. Nesse sentido, deve o juiz determinar, se necessário, a realização de provas, oitiva de testemunhas referidas, exibição de coisas $\operatorname{etc}^{368}$.

$\mathrm{Na}$ análise da prova, a postura consciente do juiz também faz a diferença. Não basta que ele espere a verdade mostrar-se, evidente, perante seus olhos, de forma categórica e insofismável. No âmbito da ação inibitória, a prova, como se viu, é complexa e em geral feita por indícios e presunções. Sua apreciação deve ser orientada pela

${ }^{365}$ PONTINHA, 2009, p. 207.

${ }^{366}$ Vide tópico 3.3, supra.

367 “Com efeito, se os direitos humanos fundamentais têm por característica a irrenunciabilidade, está claro que as convenções de prova ou a própria inércia das partes não podem redundar, direta ou indiretamente, na disposição ou menoscabo daquele direito (como, p. ex., o direito à vida, ao tratamento igualitário, à integridade física, à saúde psíquica, ao meio ambiente do trabalho equilibrado, etc.). E, se é assim, resulta evidente que a natureza pública dos interesses em jogo exige, do juiz do Trabalho, que não transija com a verdade formal e nem com ela se satisfaça, senão muito excepcionalmente (quando, ante a impossibilidade de produção de provas hábeis, houver de decidir exclusivamente pela repartição do ônus da prova)." (FELICIANO, 2005, p. 25). Cf. também PIRES, 2011, p. 75-76.

${ }^{368}$ Manoel Antonio TEIXEIRA FILHO entende, por sua vez, que nos processos individuais é grande a incidência do princípio dispositivo, mas ressalva que "o reconhecimento desse fato, todavia, não impede que se possa sustentar, com apoio na lei em vigor, a possibilidade de o Juiz do Trabalho tomar a iniciativa de determinar, em certas hipóteses, que a parte produza prova dos fatos alegados." (A prova no processo do trabalho. 9 ed. São Paulo: LTr, 2010, p. 114). BEDAQUE salienta que "verdade e certeza são conceitos absolutos, dificilmente atingíveis. Mas é imprescindível que se diligencie, a fim de que o grau de probabilidade seja o mais alto possível. Quanto maior sua participação na atividade instrutória, mais perto da certeza ele [o juiz] chegará". (2001, p. 15). 
sensibilidade do julgador, e também por sua experiência e conhecimento da realidade social $^{369}$. Ainda que os indícios estejam presentes nos autos, sempre será fácil, por assim dizer, negar a tutela inibitória em razão da "ausência de prova suficiente"; porém, ao juiz comprometido com a missão constitucional da tutela inibitória, e do próprio processo do trabalho, não basta olhar, é preciso ver, e é preciso querer ver. O espírito do juiz deve estar imbuído dos valores que informam sua atuação nessa espécie de processo: proteção da dignidade da pessoa, e de forma geral a tutela dos direitos fundamentais. Esse espírito é incompatível com o excesso de exigência na apreciação da prova tendente a demonstrar a necessidade da tutela inibitória.

A análise dos indícios demonstrados nos autos deve se pautar pelo conhecimento que o juiz tem da realidade social. Ora, o autoritarismo nas relações de trabalho no Brasil tem raízes históricas conhecidas ${ }^{370}$, e é perceptível iniludivelmente nas lides trabalhistas típicas, com as quais o juiz do trabalho tem contato diário. Ao analisar a prova indiciária para decidir acerca da tutela inibitória, não pode o juiz esquecer-se do que vê todos os dias, e exigir uma comprovação cabal da alegação de assédio moral pelo empregador, como se não militasse em favor do autor da ação a mínima presunção de plausibilidade, à vista, é claro, de indícios razoáveis ${ }^{371}$. A questão é que, no âmbito da ação inibitória, a própria razoabilidade dos indícios pode muitas vezes resumir-se a um juízo valorativo do magistrado, e por isso o excesso de rigor na análise da prova implicará a improcedência da quase totalidade dos pedidos $^{372}$. Com esse tipo de postura, não restarão

\footnotetext{
${ }^{369}$ Nesse sentido, MARINONI refere expressamente a importância do uso do senso comum e de experiência do magistrado na apreciação da prova em ação inibitória (2002, p. 14-15). PONTINHA ressalta "o relevante papel que possui o magistrado para que a ameaça possa ser devidamente observada e a prevenção possa ser exercida pelo direito. No que atine ao impedimento de ato ilícito em corrente ameaça, a sensibilidade que deve ter o magistrado na análise das provas assume especial destaque" (2009, p. 208). Rodolfo PAMPLONA FILHO, igualmente, embora trate diretamente de questões relacionadas a assédio sexual, corrobora a importância da prova por indícios e presunções (Assédio sexual na relação de emprego. 2 ed. São Paulo: LTr, 2011, p. 129-131).

${ }^{370}$ Vide a respeito as considerações expostas no bojo do tópico 4.2.3.2, supra.

371 "É recomendável, contudo, sempre trazer à luz algum indício do assédio (rigor evidente, queda involuntária de produção, tratamento diferenciado, etc.); se todas as descrições indiciárias forem negadas e não houver um elemento sequer que as corrobore, a narrativa torna-se fantasiosa e, nesse caso, inverter o ônus da prova significará impor, sem mais, a condenação, em afronta ao devido processo legal." (FELICIANO, 2005, p. 23).
}

372 Aliás, esse é o próprio contexto do sistema de persuasão racional na apreciação das provas, o qual não representa novidade no ordenamento processual brasileiro. Já na década de 50 do século passado, Moacyr Amaral SANTOS salientava que, nesse sistema, "a liberdade que se concede ao juiz reside na faculdade que tem de estimar a prova através da convicção que qualquer delas produz em seu espírito, preponderando sobre 
dúvidas de que o deferimento de tutelas inibitórias de assédio moral ficará restrito a ínfimos casos.

Com as proposições acima não se está a transigir com a imparcialidade do julgador. O juiz deve mesmo ser imparcial, mas imparcialidade não se confunde com neutralidade ${ }^{373}$. O juiz não se torna parcial quando assume valores que fundamentam a ordem constitucional e, consequentemente, todo o ordenamento jurídico. Ao assumir que seu espírito se volta à proteção da dignidade da pessoa e à tutela dos direitos fundamentais, o juiz não se declara parcial, antes pelo contrário: é a neutralidade axiológica que leva o magistrado a privilegiar o poder social da parte mais forte da relação jurídica. Pôr o pensamento a procurar indícios de assédio moral não acarreta a parcialidade do julgador, pois é justamente essa sua missão constitucional.

\subsection{Sentença e coisa julgada em ação inibitória}

Este tópico tem o objetivo de analisar algumas questões relevantes no que diz respeito à sentença e à coisa julgada na ação inibitória.

Já se expôs que a sentença da ação inibitória não é de condenação; não é uma sentença que declara a obrigação do réu e abre ao autor a possibilidade de utilizar o aparato processual da execução forçada por expropriação. Não se aplica à tutela inibitória a lógica da sentença condenatória, até porque a necessidade da tutela inibitória é compreendida, justamente, a partir da ineficiência do sistema da sentença condenatória e da execução por expropriação para a tutela efetiva de direitos que, por sua natureza, não se comprazem com a substituição por equivalente pecuniário.

as demais [...]. Assim, tanto poderá persuadir-se na prova feita por uma só testemunha, contrariando o brocardo testis unus, testis nullus, relegando as demais testemunhas, como poderá negar eficácia a todas elas, por se convencer da inverossimilhança das suas assertivas". (Prova judiciária no cível e comercial. 2 ed. São Paulo: Max Limonad, 1952, v. 1, p. 334).

${ }^{373}$ Esse tema já foi objeto de análise no tópico 5.1, supra. Repise-se que "superou-se há muito, é certo, a ficção de que o juiz seria um agente neutro de execução de subsunções lógicas, não lhe cabendo qualquer papel criativo ou inovador. Se essa crença já era ilusória no século XIX e na primeira metade do século XX, que se dirá nos dias de hoje, tendo em conta a abertura dos sistemas jurídicos contemporâneos?" (BARCELLOS, 2005, p. 43-44). 
A sentença que defere a tutela inibitória será, conforme seu conteúdo: a) mandamental, quando impuser ao réu uma ação ou omissão, sob cominação de multa ou outro meio de coerção indireto; b) executiva, quando prestar diretamente a tutela inibitória, independentemente da vontade e do agir do réu. Quando a sentença determina ao réu a cessação de práticas abusivas de avaliação e estímulo de rendimento dos empregados, sob pena de multa diária pelo não cumprimento, essa sentença é mandamental. Será, porém, executiva a sentença que determine a remoção imediata, por Oficial de Justiça, de um quadro de produtividade ou ranking de vendedores em que haja a violação da intimidade ou da honra dos trabalhadores.

De fato, não faz sentido pensar em execução por expropriação quando se está a lidar com tutela preventiva. $\mathrm{O}$ autor da ação não tem nenhum interesse em executar a sentença no sentido de citar o réu para pagamento e depois buscar bens penhoráveis para garantir a quitação. Tem-se uma tutela de natureza distinta, e incompatível com a execução de sentença (ou fase de cumprimento de sentença) nos moldes previstos no capítulo $\mathrm{X}$ do Título VIII do Código de Processo Civil.

A tutela inibitória será prestada na ação de conhecimento, com o cumprimento da obrigação imposta na sentença. Sendo esta de natureza executiva, não há sequer o que esperar do comportamento do réu, pois o ato será cumprido pelo próprio Estado. Sendo mandamental a sentença, espera-se a conduta do réu, pressionado pela aplicação dos meios de coerção indiretos, mas a recalcitrância pode ensejar o agravamento desses meios indiretos ou, até mesmo, a conversão da determinação para um fazer imediato pelo Estado - o que equivaleria a uma transformação do provimento judicial, que passaria a ser executivo, não mais mandamental.

Nessa modificação, não há falar em afronta aos direitos de defesa do réu, ou ao princípio da adstrição do juiz ao pedido ${ }^{374}$. Se na ação inibitória os direitos em jogo requerem uma proteção efetiva do Estado, o juiz deve prestar a tutela que se mostre mais

${ }^{374}$ BEBBER, 1997, p. 297; MARINONI, 2008, p. 104-105.

Convém salientar, todavia, que à jurisprudência brasileira em geral o princípio da adstrição ainda é bastante caro: "Princípio da adstrição. Pedidos não formulados na petição inicial. Decisão extra e ultrapetita. A decisão ultra ou extrapetita ocorre quando o magistrado decide além ou fora do pedido, respectivamente, violando o princípio da adstrição, ou seja, os limites postos na lide [...].” (TRT/2 ${ }^{\mathrm{a}}$ Região. RO 00016541720105020252, Rel. Wilma Gomes da Silva Hernandes, DOE 5.12.2012). 
eficaz, ainda que não tenha sido a postulada na petição inicial. Tal conclusão decorre diretamente da interpretação do direito fundamental de ação ( $\mathrm{CF}$, art. $\left.5^{\circ}, \mathrm{XXXV}\right)$, mas não deixa de ser conveniente salientar a permissão da legislação ordinária nesse tema, pois os $\S \S 4^{\circ}, 5^{\circ}$ e $6^{\circ}$ do art. 461 do CPC mencionam expressamente as possibilidades de atuação de ofício do juiz, ou "independentemente de pedido do autor". É evidente que a vontade legislativa seguiu no mesmo sentido da vontade do constituinte: cabe ao juiz agir de ofício, se necessário, para prestar a tutela mais efetiva ao direito ameaçado no caso concreto ${ }^{375}$.

A fundamentação da sentença assume, por sua vez, importância vital na teoria da ação inibitória. De fato, o reconhecimento amplo dos poderes judiciais enseja uma plausível preocupação com o arbítrio do juiz ao decidir. Seja na apreciação da prova, seja no deferimento das medidas de tutela adequadas ao caso (e ao próprio juízo de adequação dessas medidas!), o poder discricionário do magistrado será fiscalizado pela consistência da fundamentação de sua decisão ${ }^{376}$. É da fundamentação da sentença que decorre, portanto, a legitimidade do exercício do poder pelo juiz.

Dois são basicamente os aspectos da fundamentação da sentença em ação inibitória; o primeiro é o que se pode chamar de fundamentação fática, isto é, a parte que toca às questões da conduta temida, sua prova, a apreciação dos indícios e as presunções. $\mathrm{O}$ segundo aspecto diz respeito à fundamentação jurídica, a qual abrange a análise da antijuridicidade da conduta do réu e também o juízo sobre a eficácia do meio de tutela mais adequado ao caso concreto.

\footnotetext{
375 "Os arts. 461 do CPC e 84 do CDC admitem expressamente que o juiz pode conceder a tutela específica da obrigação ou o resultado prático equivalente ao do adimplemento. Com isto, o juiz está autorizado, desde que respeitados os limites da obrigação originária, a impor o fazer ou o não fazer mais adequado à situação concreta que lhe é apresentada para julgamento." (MARINONI, 2012, p. 132).

No mesmo sentido: "O art. 11 da Lei 7.347/85, o art. 84 , $\S \S 4^{\circ}$ e $5^{\circ}$, do CDC, e, principalmente, o $\S 5^{\circ}$ do art. 461 do CPC, deixam clara a possibilidade do Juiz, ex officio, deferir a tutela específica na forma que mais eficazmente resguardar a situação de direito material vindicada. $\mathrm{O}$ art. $4^{\circ}$ do Anteprojeto de Código de Processo Civil Coletivo estabelece que 'nas ações coletivas, a causa de pedir e o pedido serão interpretados extensivamente, em conformidade com o bem jurídico a ser protegido'. Trata-se, sem dúvida, da mitigação do princípio da adstrição da sentença ao pedido e causa de pedir, também chamado de princípio da congruência e prescrito pelos arts. 128 e 460 do Código de Processo Civil." (FABRE e LAVEZO, 2010, p. 5939). Cf. também PONTINHA, 2009, p. 209.

376 "Fundamentar significa o magistrado dar as razões, de fato e de direito, que o convenceram a decidir a questão daquela maneira." (NERY JUNIOR, 1996, p. 170).
} 
Apesar da distinção exposta, não se há de aplicar uma separação estanque entre esses aspectos, pois eles são na verdade momentos de uma mesma decisão. Em primeiro lugar, antes de tudo, o juiz deve analisar a questão jurídica da alegada ilicitude da conduta que o réu supostamente praticará. Com efeito, se dessa análise concluir o juiz que o ato que o autor descreveu na petição inicial não é ilícito, ele indeferirá a tutela pleiteada, restando prejudicada a análise dos demais elementos do processo.

Por outro lado, convencendo-se o juiz da ilicitude do ato descrito na petição inicial, deve ele expor motivadamente seu convencimento na sentença, e passar às fases seguintes da fundamentação. O próximo item de análise será a apreciação das questões fáticas pertinentes à prova. Reitere-se que a prova na ação inibitória será na maioria dos casos indiciária, isto é, o convencimento do juiz será proporcionado por um raciocínio presuntivo decorrente da demonstração de indícios de que a alegação da petição inicial é verdadeira.

Assim, deve o juiz expor na sentença o raciocínio que o levou a concluir que a conduta ilícita será, provavelmente, praticada pelo réu; deve expor os motivos que o levaram a atribuir importância a alguns indícios, ou a negar-lhes relevância. Da mesma forma, deve o juiz indicar na sentença as razões que o tenham levado a indeferir a tutela por reputar insuficiente a prova dos autos. As partes têm, portanto, o direito de conhecer o encadeamento do raciocínio do juiz, para que possam tentar demonstrar em instância recursal a existência de falhas no pensamento do magistrado, de modo a obter a reforma da decisão ${ }^{377}$.

Por fim, e uma vez convencido da probabilidade da conduta ilícita, deve o juiz fundamentar a decisão no tocante à adequação do meio de tutela escolhido. E nesse aspecto deve ser retomado o conteúdo do princípio da necessidade, do qual já se fez referência em tópico anterior ${ }^{378}$. O juiz atenderá ao princípio da necessidade se adotar a espécie de tutela

\footnotetext{
377 Conforme salientado por NERY JUNIOR, “a menção pura e simples aos documentos da causa ou testemunhas como circunstâncias autorizadoras do decreto judicial, sem qualquer análise concreta dos referidos documentos e demais provas dos autos, não preenche o requisito constitucional da motivação como fator da higidez das decisões judiciais" (1996, p. 171).

${ }^{378}$ Vide tópico 5.5, supra.
} 
que ao mesmo tempo se apresente idônea para a efetiva proteção do direito do autor e implique ao réu a menor restrição possível em seu patrimônio jurídico.

Dito de outro modo, cabe ao juiz analisar quais são as medidas de tutela idôneas à proteção do direito do autor e, dentre elas, adotar aquela que cause a menor restrição ao réu. E na fundamentação da sentença se espera ver a motivação de ambos os aspectos do princípio da necessidade.

Convém ainda salientar a imediata eficácia da sentença, desde sua publicação. Não obstante a característica diversa do regime jurídico previsto no CPC ainda em vigência, o processo do trabalho possui regramento específico sobre o assunto. O art. 899 da CLT dispõe que os recursos possuem, em geral, efeito meramente devolutivo, ou seja, a interposição de recurso ordinário em face da sentença não tem o condão de suspender os efeitos da decisão, como ocorre com o recurso de apelação, em algumas hipóteses do processo civil $^{379}$. Aliás, o Tribunal Superior do Trabalho possui entendimento consolidado no sentido da necessidade de demanda específica do recorrente para dotar seu recurso de efeito suspensivo ${ }^{380}$.

Portanto, o cumprimento da sentença da ação inibitória, no processo do trabalho, não depende do trânsito em julgado. O cumprimento deve ser imediato, ressalvada a exceção de ter o interessado obtido efeito suspensivo em grau recursal. Por essa mesma razão, é desnecessário que o juiz emita, na sentença, uma "antecipação da tutela", para dotar o provimento jurisdicional de efeito imediato. Tal efeito imediato existe em decorrência de lei; a prática da "antecipação de tutela na sentença" se justifica mais no processo civil, em que o recebimento do recurso de apelação suspende os efeitos da sentença, como regra geral. O regime recursal do processo do trabalho torna irrelevante essa decisão adicional.

A propósito, não apenas a sentença tem eficácia imediata; também a decisão que antecipa a tutela inibitória, liminarmente ou após o recebimento da defesa, é dotada da

\footnotetext{
379 Note-se que o recurso de apelação, no processo civil, é recebido, em regra, nos efeitos devolutivo e suspensivo (CPC, art. 520).

${ }^{380} \mathrm{O}$ entendimento consolidado do TST (sobre cujo teor opta-se por não emitir juízo de valor) é de que "a ação cautelar é o meio próprio para se obter efeito suspensivo a recurso" (Súmula 414, inciso I).
} 
mesma força. Seria insustentável a proposição de que a tutela inibitória antecipada, fundada justamente no receio da demora do provimento final do processo, fosse inexequível de plano. Na medida em que se suprimisse a eficácia imediata da tutela inibitória antecipada, a própria existência da tutela inibitória, como técnica de tutela destinada a proteger de maneira eficaz os direitos fundamentais, estaria comprometida.

Em nada afeta essa conclusão o argumento de que a parte final do art. 899 da CLT permite a "execução provisória até a penhora". Ora, é inegável que tal dispositivo se dirige exclusivamente às hipóteses nas quais a sentença condenatória será executada pelo sistema tradicional da execução por expropriação. Em se tratando de sentença que defere tutela inibitória, não se terá execução por expropriação e, consequentemente, não se terá penhora. Não é aplicável a essa sentença, então, a restrição contida na parte final do art. 899 da CLT; seja à sentença propriamente dita, seja à decisão que defere a tutela inibitória antecipadamente.

Para finalizar este tópico, algumas considerações sobre a coisa julgada no âmbito da ação inibitória.

Em primeiro lugar, a conclusão do juízo sobre a licitude ou ilicitude do ato é abrangida pela coisa julgada, pois representa um pronunciamento do juiz sobre ponto essencial do mérito da controvérsia. Assim, se a sentença de procedência declara o caráter ilícito do ato de que se cuida no processo, essa natureza não mais será passível de discussão em outro feito. Da mesma forma, se a sentença é de improcedência fundada na licitude do ato temido pelo autor, a coisa julgada material torna impossível ao autor questionar essa licitude em outro processo.

Tendo a sentença deferido a tutela inibitória em relação a determinado ato do réu, uma vez transitada em julgado ela impede a prática daquele ato, circunscrito no tempo e no espaço, e também a prática de ato com o mesmo conteúdo, ainda que fora dos mesmos limites de espaço e tempo. Exemplifique-se com a sentença que proíba a colocação de um quadro que exponha um ranking de produtividade de forma agressiva à honra e dignidade dos empregados. Após o trânsito em julgado, o empregador não poderá usar o mesmo quadro, mas também lhe será vedado usar outro quadro com conteúdo similar àquele primeiro. Em tal hipótese, poderá o autor da ação simplesmente peticionar ao juiz da causa 
postulando nova tutela para o desrespeito do réu ao comando da sentença, sem necessidade de propor outra ação inibitória, para cognição exaustiva pelo magistrado ${ }^{381}$.

É possível, ainda, que a sentença, a despeito de rejeitar a pretensão inibitória, não tenha declarado a licitude da conduta temida pelo autor; por exemplo, quando o fundamento da improcedência tenha sido a ausência ou insuficiência de prova. A renovação do pedido em outra ação, nesses casos, é possível quando respeitada a identificação da ação, isto é, quando haja fundamento que diferencie a causa de pedir de ambos os processos.

Assim, se é vedado ao autor, por força da coisa julgada, repetir a mesma ação já julgada em definitivo, e sendo a ação identificada pela tríplice identidade (partes, pedido e causa de pedir), somente com outra causa de pedir poderá o autor repetir o mesmo pedido inibitório em face do réu. Nesse caso se terá outra ação, com fundamento distinto daquela que fora julgada em definitivo.

\footnotetext{
381 "A imutabilidade da coisa julgada se projeta para o futuro, alcançando todas as situações que tenham identidade com a que foi objeto da decisão. Decidindo-se que determinado ato temido é ilícito, e assim não pode ser praticado, é pouco mais do que evidente que não é somente o ato narrado na petição inicial que não poderá ser praticado. Veda-se que o réu volte a praticar ato com o mesmo conteúdo do reconhecido ilícito na sentença que produziu coisa julgada material. Assim, surgindo circunstâncias semelhantes àquelas que justificaram a decisão que já produziu coisa julgada material, bastará solicitar ao juiz ordem para que o novo ato temido não venha a ser praticado, não tendo cabimento exigir que o juiz decida, novamente, sobre a licitude ou ilicitude do ato.” (MARINONI, 2012, p. 146)
} 


\section{CONCLUSÕES}

Um capítulo de conclusão encerra alguns perigos, um dos quais o de deixar parecer que o trabalho concluído alcançou algo como a verdade absoluta, ou o perfeito juízo acerca do objeto da investigação.

A ressalva que deve ser feita neste derradeiro capítulo é, portanto, que a pesquisa alcançou um ponto de chegada, e é nesse sentido que ela está concluída. Evidentemente, porém, qualquer ponto de chegada pode ser visto como o ponto de partida em direção a novos destinos. A reflexão é permanente, precisa ser permanente, e tal proposição dá o necessário caráter temporal das conclusões e juízos expostos neste trabalho. Não se pretende, de forma alguma, assumir posições definitivas ou absolutas. A verdade absoluta é inatingível, principalmente no âmbito das ciências sociais aplicadas. $\mathrm{O}$ que se alcança por meio da ciência é a verdade histórica, a verdade possível.

Feita essa ressalva, serão doravante expostas as principais conclusões que se pôde extrair da pesquisa apresentada.

Em primeiro lugar, na linha do quanto se apontou no capítulo 3, assumida a função do processo do trabalho de realização de direitos fundamentais, e ainda a vinculação direta das partes do contrato de trabalho às normas de direitos fundamentais, é forçoso concluir que a característica patrimonialista do processo do trabalho brasileiro é um entrave à sua própria missão constitucional.

Com efeito, a partir do momento em que se assenta a ideia de que os direitos fundamentais dos trabalhadores não aceitam conversão em valores pecuniários, é necessário que o processo do trabalho volte suas preocupações à vida, à saúde, à integridade física e psíquica das pessoas, especialmente da perspectiva da prevenção de lesões a esses direitos. A lógica da conversão das obrigações em indenização de perdas e danos não faz mais sentido (se é que outrora fez) em um ordenamento como o brasileiro pós-1988, que pretende consagrar e tutelar os direitos fundamentais. 
A lógica do processo só pode ser, então, a lógica da prevenção.

Considerando, ademais, o que foi trazido no capítulo 4, na medida em que um dos direitos fundamentais dos trabalhadores é o de desfrutar de um meio ambiente do trabalho sadio e equilibrado, abrangidos os aspectos físicos e também psicológicos do conceito, cumpre salientar a necessidade premente, aqui, da incidência da lógica da prevenção.

O assédio moral, nesse contexto, se apresenta como um verdadeiro agente poluente do meio ambiente do trabalho, em especial da perspectiva psicológica. Daí a conclusão de que a busca da prevenção do assédio moral deve ser posta na ordem do dia das preocupações do direito processual do trabalho.

Ora, se o processo do trabalho deve assumir a lógica da prevenção e se há fortes razões de índole constitucional para sustentar que a prevenção do assédio moral no meio ambiente do trabalho é uma importante medida de proteção de direitos fundamentais, a tutela inibitória deve ser valorizada no âmbito laboral.

Destina-se a tutela inibitória a prevenir a prática, a continuação ou a repetição de ato ilícito. Por esse conceito se pôde compreender a importância de ampliar sua aplicação no processo do trabalho, máxime para a prevenção do assédio moral.

O regime jurídico da tutela inibitória é distinto do tradicional sistema processual de condenação e execução por expropriação. Esse sistema, procurou-se demonstrar, é baseado em postulados liberais com raízes na fase de autonomia científica do direito processual, postulados esses que se mostram hoje insuficientes para responder às necessidades sociais de tutela jurisdicional adequada e tempestiva.

A tutela inibitória é prestada por sentença mandamental ou, em menor número de casos, por sentença executiva. É inerente a essa modalidade de tutela o aumento da discricionariedade do juiz na apreciação do caso concreto e na determinação de medidas eficazes à proteção do direito material. Por isso, mostra-se pouco viável a tarefa de tipificar quais seriam as tutelas inibitórias eficazes em determinadas situações de assédio moral. 
Cabe ao magistrado, diante do caso concreto, impor ao réu o comportamento (omissivo ou comissivo) necessário para prevenir a prática, a repetição ou a continuação do assédio moral no meio ambiente do trabalho. Alguns exemplos práticos foram mencionados no decorrer do capítulo 5.

A concentração dos poderes do juiz possibilita, eventualmente, a prática de excessos e mesmo abusos de poder. Por essa razão salientou-se a importância da fundamentação das decisões, de modo a conferir legitimidade ao ato judicial.

Finalmente, não se pode evitar a conclusão de que todos os fatores que se entrelaçam no tema recomendam o incremento da atitude e da postura dos juízes. Seja pela superação do dogma liberal da neutralidade na iniciativa probatória, seja pelo poder de determinar medidas independentemente de pedido expresso do autor, seja mesmo pelo reconhecimento de sua atuação de ofício no que tange à tutela preventiva, o juiz do trabalho deve agir imbuído dos valores que dão sentido ao processo do trabalho e, consequentemente, à sua própria função e legitimidade.

De nada adiantará sustentar constitucionalmente a lógica da prevenção e o cabimento da tutela inibitória em relação ao assédio moral, se o juiz se revelar demasiadamente apegado ao vetusto sistema do processo liberal. Está-se diante de um problema que não é exclusivamente jurídico, tem também conotações políticas e, sobretudo, ideológicas.

Pouco úteis serão as ferramentas processuais destinadas à prevenção de assédio moral se a racionalidade dos juízes se mantiver conservadora em essência ${ }^{382}$, no sentido de repelir a lógica da prevenção sempre que esta lógica colidir com os postulados do processo liberal tradicional ${ }^{383}$.

\footnotetext{
${ }^{382}$ A propósito, Rui PORTANOVA salienta que "a segurança é valor que por si só se opõe ao valor justiça. O desejado de decisões mais previsíveis, mais uniformes, choca-se com os ideais de justiça. É que justiça tem que compreender o ineditismo da vida, a mudança contínua. O valor justiça é mais importante que o valor segurança. Esta fundamentalmente garante a segurança das classes que fizeram a lei ou tiveram papel preponderante na sua feitura. Não há deixar de reconhecer, tal postura leva a certa insegurança" (2003, p. 61).

383 Convém aqui recordar a advertência formulada por José Carlos Barbosa MOREIRA, no contexto do surgimento da nova ordem jurídica brasileira fundada pela Constituição Federal em 1988, a qual exigia novas posturas dos juízes: "Outra possível explicação para a resistência a mudanças é a pura e simples indolência mental. Abandonar a rotina demanda esforço que pode ser desagradável, quiçá penoso. Se nos acostumamos a dar aos nossos problemas, por tempo considerável, as mesmas soluções, há forte probabilidade de que pelo
} 
Mesmo correndo o risco de transparecer um idealismo excedente dos estritos objetivos da pesquisa acadêmica, encerra-se este trabalho com uma conclamação à reflexão, à crítica e à abertura do espírito ao novo: uma nova lógica é exigida pelo processo contemporâneo, e essa nova lógica exige por sua vez novas posturas diante de novos problemas. É o momento de olhar para a frente, de construir um processo melhor, talvez até uma sociedade melhor.

$\mathrm{Na}$ busca desse horizonte, certamente haverá alguns erros, alguns desvios e contratempos; o cansaço pode render um desânimo passageiro; mas não é permitido desistir. Que fiquem na memória os versos cantados por Raul Seixas:

\section{Queira,}

Basta ser sincero e desejar profundo

Você será capaz de sacudir o mundo Tente outra vez

Tente,

E não diga que a vitória está perdida

Se é de batalhas que se vive a vida

Tente outra vez! $!^{384}$

menos alguns de nós encarem com pouco entusiasmo o desafio de procurar novas soluções ou - pior ainda de enfrentar novos problemas." ( $O$ Poder Judiciário e a efetividade da nova Constituição. Revista Forense. Rio de Janeiro, ano 84, v. 304, outubro/dezembro 1988, p. 152).

${ }^{384}$ Raul Seixas. “Tente outra vez”. In: Novo Aeon. Rio de Janeiro: Polygram, 1975. 


\section{REFERÊNCIAS BIBLIOGRÁFICAS}

AGUIAR, André Luiz Souza. Assédio moral: o direito à indenização pelos maus-tratos $e$ humilhações sofridos no ambiente do trabalho. 2 ed. São Paulo: LTr, 2006.

ALEXY, Robert. Teoria dos direitos fundamentais. 2 ed. Tradução de Virgílio Afonso da Silva. São Paulo: Malheiros, 2011.

ALKIMIN, Maria Aparecida. Assédio moral na relação de trabalho. 2 ed. Curitiba: Juruá, 2009.

ASSE, Vilja Marques. Um fenômeno chamado psicoterrorismo. Revista LTr, São Paulo, v. 68 , n. 7, julho/2004, pp. 819-827.

ÁVILA, Humberto. Teoria dos princípios: da definição à aplicação dos princípios jurídicos. 12 ed. São Paulo: Malheiros, 2011.

AZEVEDO, Antônio Junqueira de. Caracterização jurídica da dignidade da pessoa humana. Revista USP. São Paulo, n. 53, março/maio 2002, pp. 90-101.

BARACAT, Eduardo Milléo. A boa-fé no direito individual do trabalho. São Paulo: LTr, 2003.

BARCELlOS, Ana Paula de. Ponderação, racionalidade e atividade jurisdicional. Rio de Janeiro: Renovar, 2005.

BARRETO, Margarida. Violência, saúde e trabalho: uma jornada de humilhações. São Paulo: EDUC, 2006. 
BARROS, Alice Monteiro de. Proteção à intimidade do empregado. 2 ed. São Paulo: LTr, 2009.

BEBBER, Júlio César. Princípios do processo do trabalho. São Paulo: LTr, 1997.

Cumprimento da sentença no processo do trabalho. 2 ed. São Paulo: LTr, 2007.

Processo do trabalho: adaptação à contemporaneidade. São Paulo: LTr, 2011.

BEDAQUE, José Roberto dos Santos. Poderes instrutórios do juiz. 3 ed. São Paulo: Editora Revista dos Tribunais, 2001.

Efetividade do processo e técnica processual. 2 ed. São Paulo: Malheiros, 2007.

BELTRAN, Ari Possidonio. Direito do Trabalho e Direitos Fundamentais. São Paulo: LTr, 2002.

BITTAR, Carlos Alberto. A missão do juiz no processo moderno. Revista dos Tribunais, ano 83, v. 704, junho/1994, pp. 265-267.

BOBBIO, Norberto. A Era dos Direitos. Tradução de Carlos Nelson Coutinho. Nova edição. 10ª reimpressão. Rio de Janeiro: Editora Elsevier, 2004.

BONAVIDES, Paulo. Curso de direito constitucional. 13 ed. São Paulo: Malheiros, 2003.

BRANCO, Ana Paula Tauceda. A colisão de princípios constitucionais no direito do trabalho. São Paulo: LTr, 2007.

CAHALI, Yussef Said. Dano moral. 3 ed. São Paulo: RT, 2005.

CANOTILHO, José Joaquim Gomes. Direito constitucional e teoria da constituição. 7 ed. Coimbra: Almedina, 2003.

CAPPELLETTI, Mauro. GARTH, Bryant. Acesso à justiça. Trad. Ellen Gracie Northfleet. Porto Alegre: Sergio Antonio Fabris Editor, 1988. 
CATALDI, Maria José Giannella. Stress no meio ambiente de trabalho. 2 ed. São Paulo: LTr, 2011.

CAVALIERI FILHO, Sérgio. Programa de responsabilidade civil. 6 ed. São Paulo: Malheiros, 2005.

CERQUEIRA, Vinícius da Silva. Assédio moral organizacional nos bancos. Dissertação de Mestrado. São Paulo: Faculdade de Direito da Universidade de São Paulo, 2012.

CHAVES, Luciano Athayde. A recente reforma no processo comum: reflexos no direito judiciário do trabalho. 3 ed. São Paulo: LTr, 2007.

CINTRA, Antônio Carlos de Araújo. DINAMARCO, Cândido Rangel. GRINOVER, Ada Pellegrini. Teoria geral do processo. 10 ed. São Paulo: Malheiros, 1994.

COMPARATO, Fábio Konder. A afirmação histórica dos direitos humanos. 8 ed. São Paulo: Saraiva, 2013.

CORDEIRO, Wolney de Macedo. A tutela inibitória como elemento concretizador das medidas anti-discriminatórias no âmbito da relação de trabalho. Jus Navigandi. Teresina, ano 13, n. 2075, 7.3.2009. Disponível em http://jus2.uol.com.br/doutrina/texto.asp?id=12407. Acesso em 16.10.2010.

CORREIA, Marcus Orione Gonçalves. As ações coletivas e o direito do trabalho. São Paulo: Saraiva, 1994.

CUNHA, Rodrigo Giostri da. O processo do trabalho como instrumento de efetivação dos direitos sociais trabalhistas: contribuições para o aprimoramento da prestação jurisdicional trabalhista. Dissertação de Mestrado. São Paulo: Faculdade de Direito da Universidade de São Paulo, 2008.

DALLARI, Dalmo de Abreu. O poder dos juízes. 3 ed. São Paulo: Saraiva, 2007.

DALLEGRAVE NETO, José Affonso. Responsabilidade civil no direito do trabalho. 3 ed. São Paulo: LTr, 2008.

DELGADO, Maurício Godinho. Curso de direito do trabalho. 4 ed. São Paulo: LTr, 2005. 
DIMOULIS, Dimitri. MARTINS, Leonardo. Teoria geral dos direitos fundamentais. 3 ed. São Paulo: Editora RT, 2011.

DINAMARCO, Cândido Rangel. A instrumentalidade do processo. 15 ed. São Paulo: Malheiros, 2013.

DINIZ, Ana Paola Santos Machado. Saúde no trabalho: prevenção, dano e reparação. São Paulo: LTr, 2003.

FABRE, Luiz Carlos Michele. LAVEZO, Taís. Tutela inibitória na ação civil pública trabalhista. O Trabalho. Curitiba, número 166, p. 5932-5945, dezembro/2010.

FAVA, Marcos Neves. Ação civil pública trabalhista: teoria geral. 2 ed. São Paulo: LTr, 2008.

Execução trabalhista efetiva. São Paulo: LTr, 2009.

FELICIANO, Guilherme Guimarães. Tutela processual dos direitos humanos nas relações de trabalho. Jus Navigandi. Teresina. Ano 10, n. 910, 30.12.2005. Disponível em http://jus2.uol.com.br/doutrina/texto.asp?id=7810. Acesso em 17.10.2010.

Tutela inibitória em matéria labor-ambiental. Revista do TST. Brasília, v. 77, número 4, pp. 140-161, out/dez 2011.

(coord.). Fênix: por um novo processo do trabalho. São Paulo: LTr, 2011.

FIGUEIREDO, Guilherme Jose Purvin de. Direito ambiental e a saúde dos trabalhadores. 2 ed. São Paulo: LTr, 2007.

FIORELLI, José Osmir. FIORELLI, Maria Rosa. MALHADAS JÚNIOR, Marcos Júlio Olivé. Assédio moral: uma visão multidisciplinar. São Paulo: LTr, 2007.

FIORILlo, Celso Antônio Pacheco. Curso de direito ambiental brasileiro. 3 ed. São Paulo: Saraiva, 2002.

FLORINDO, Valdir. Dano moral e o direito do trabalho. 4 ed. São Paulo: LTr, 2002. 
GALVÃO, Vivianny. Assédio moral: mal-estar no trabalho. Maceió: Edufal, 2011.

GIDI, Antônio. Coisa julgada e litispendência em ações coletivas. São Paulo: Saraiva, 1995.

GOSDAL, Thereza Cristina. SOBOLL, Lis Andrea Pereira (org.). Assédio moral interpessoal e organizacional: um enfoque interdisciplinar. São Paulo: LTr, 2009.

GUEDES, Márcia Novaes. Terror psicológico no trabalho. 3 ed. São Paulo: LTr, 2008.

HIRANO, Ana Farias. Acordos homologados pela Justiça do Trabalho: uma análise dos dissídios individuais na fase de conhecimento. Dissertação de Mestrado. São Paulo: Faculdade de Direito da Universidade de São Paulo, 2008.

HIRIGOYEN, Marie-France. Assédio moral: a violência perversa no cotidiano. Tradução de Maria Helena Kühner. 11 ed. Rio de Janeiro: Bertrand Brasil, 2009.

- Mal-estar no trabalho: redefinindo o assédio moral. Tradução de Rejane Janowitzer. 4 ed. Rio de Janeiro: Bertrand Brasil, 2009.

HOLANDA, Sérgio Buarque de. Raízes do Brasil. 26 ed. São Paulo: Companhia das Letras, 1995.

LAFER, Celso. A reconstrução dos direitos humanos: um diálogo com o pensamento de Hannah Arendt. São Paulo: Companhia das Letras, 1988.

LEITE, Carlos Henrique Bezerra. Ministério Público do Trabalho. 3 ed. São Paulo: LTr, 2006.

. Eficácia horizontal dos direitos fundamentais na relação de emprego. Revista Brasileira de Direito Constitucional. Número 17, janeiro/junho 2011, pp. 33-45.

LIMA, Firmino Alves. Assédio sexual e o meio ambiente do trabalho. Revista da Amatra XV. $15^{\text {a }}$ Região, número 4/2011, p. 154-172.

LIPPMANN, Ernesto. Assédio sexual nas relações de trabalho. 2 ed. São Paulo: LTr, 2004. 
LOUSADA AROCHENA, José Fernando. La prueba de la discriminación y del acoso sexual y moral em el proceso laboral. Cadernos da Amatra IV. Porto alegre, ano 2, n. 3, abril/junho 2002. Disponível em <http://www.amatra4.org.br/publicacoes/cadernos/caderno-

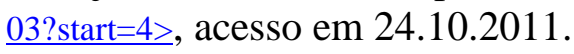

MALLET, Estevão. Direito, trabalho e processo em transformação. São Paulo: LTr, 2005.

Direitos da personalidade e direito do trabalho. Revista do TRT $7^{\mathbf{a}}$ Região, Fortaleza, ano 30, n. 30, janeiro/dezembro 2007, pp. 135-159.

MANCUSO, Rodolfo de Camargo. Ação civil pública: em defesa do meio ambiente, do patrimônio cultural e dos consumidores. 10 ed. São Paulo: Editora RT, 2007.

MARINONI, Luiz Guilherme. A prova na ação inibitória. Revista Jurídica Nota Dez. Porto Alegre, ano 50, número 294, pp. 7-15, abril/2002.

Tutela inibitória e tutela de remoção do ilícito. Jus Navigandi. Teresina. Ano 9. n. 272, 5 abril 2004. Disponível em <http://jus.com.br/revista/texto/5041. Acesso em 23.6.2012.

ARENHART, Sérgio Cruz. Manual do processo de conhecimento. 5 ed. São Paulo: Editora RT, 2006.

2006.

Curso de processo civil: teoria geral do processo. v. 1. São Paulo: Editora RT, Antecipação da tutela. 9 ed. São Paulo: RT, 2006.

Técnica processual e tutela dos direitos. 2 ed. São Paulo: RT, 2008.

Tutela inibitória: individual e coletiva. 5 ed. São Paulo: Editora RT, 2012.

MAZZILLI, Hugo Nigro. A defesa dos interesses difusos em juízo. 16 ed. São Paulo: Saraiva, 2003. 
MELO, Raimundo Simão de. Direito ambiental do trabalho e a saúde do trabalhador: responsabilidades legais, dano material, dano moral, dano estético. 4 ed. São Paulo: LTr, 2010.

MENDES, Gilmar Ferreira. Direitos fundamentais e o controle de constitucionalidade. 3 ed. São Paulo: Saraiva, 2004.

MENEZES, Claudio Armando Couce de. Assédio moral e seus efeitos jurídicos. Jus Navigandi. Teresina, ano 14, n. 2489, 25.4.2010. Disponível em http://jus2.uol.com.br/doutrina/texto.asp?id=14747. Acesso em 16.10.2010.

MORAES, Alexandre de. Direitos humanos fundamentais. 8 ed. São Paulo: Atlas, 2007.

Direito constitucional. 28 ed. São Paulo: Atlas, 2012.

MORAES, Maria Celina Bodin de. Danos à pessoa humana: uma leitura civilconstitucional dos danos morais. Rio de Janeiro: Renovar, 2003.

MORAES, Monica Maria Lauzid de. O direito à saúde e segurança no meio ambiente do trabalho. São Paulo: LTr, 2002.

MOREIRA, José Carlos Barbosa. O Poder Judiciário e a efetividade da nova constituição. Revista Forense. Rio de Janeiro, ano 84, v. 304, pp. 151-155, outubro/dezembro 1988.

Imparcialidade: reflexões sobre a imparcialidade do juiz. Revista Jurídica Nota Dez. Porto Alegre, ano 46, número 250, pp. 5-13. Agosto 1998.

A sentença mandamental: da Alemanha ao Brasil. Revista de Processo. São Paulo, ano 25, n. 97, pp. 251-264, janeiro/março 2000.

O novo processo civil brasileiro. 22 ed. Rio de Janeiro: Forense, 2002.

NASCIMENTO, Sônia A. C. Mascaro. O assédio moral no ambiente do trabalho. Jus Navigandi, Teresina, ano 8, n. 371, 13 jul. 2004. Disponível em: http://jus2.uol.com.br/doutrina/texto.asp?id=5433. Acesso em: 16 out. 2010.

NERY JÚNIOR, Nélson. Princípios do processo civil na Constituição da República. 3 ed. São Paulo: RT, 1996. 
OLEA, Manuel Alonso. Introdução ao direito do trabalho. Tradução da 5 ed. espanhola. Curitiba: Genesis, 1997.

OLIVEIRA, Carlos Alberto Álvaro de. O formalismo valorativo no confronto com o formalismo excessivo. PPGD-UFRGS, 2001. Disponível em: <http://www.ufrgs.br/ppgd/doutrina/CAO_O Formalismo-valorativo no confronto_com_o_Formalismo_excessivo_290808.htm> Acesso em 30.3.2013.

OLIVEIRA, Paulo Eduardo Vieira de. Direito do trabalho e cidadania. Revista LTr. v. 71. pp. 1094-1098, 2007.

. "Princípio da proteção da dignidade e da intimidade do trabalhador". In: NAHAS, Tereza Christina (Org.). Princípios de direito e processo do trabalho: questões atuais. Rio de Janeiro: Elsevier, 2009, pp . 155-177.

O dano pessoal no direito do trabalho. 2 ed. São Paulo: LTr, 2010.

2013. Assédio moral no trabalho: caracterização e consequências. São Paulo: LTr,

OLIVEIRA, Sebastião Geraldo de. Indenizações por acidente do trabalho ou doença ocupacional. 3 ed. São Paulo: LTr, 2007.

Proteção jurídica à saúde do trabalhador. 6 ed. São Paulo: LTr, 2011.

PADILHA, Normal Sueli. Do meio ambiente do trabalho equilibrado. São Paulo: LTr, 2002.

PAMPLONA FILHO, Rodolfo. O dano moral na relação de emprego. 3 ed. São Paulo: LTr, 2002.

Assédio sexual na relação de emprego. 2 ed. São Paulo: LTr, 2011.

PEDUZZI, Maria Cristina Irigoyen. O princípio da dignidade da pessoa humana na perspectiva do direito como integridade. São Paulo: LTr, 2009. 
PIOVESAN, Flávia. Direitos Humanos e o Direito Constitucional Internacional. 11 ed. São Paulo: Saraiva, 2010.

PIRES, Líbia da Graça. Teoria da distribuição dinâmica do ônus da prova no processo do trabalho. Tese de Doutorado. São Paulo: Faculdade de Direito da Universidade de São Paulo, 2011.

PLÁ RODRIGUEZ, Américo. Princípios de direito do trabalho. Trad. Wagner Giglio. 3 ed. São Paulo: LTr, 2000.

PONTINHA, Priscila Lopes. Ação inibitória no processo do trabalho e seus contornos processuais característicos. Revista Trabalhista Direito e Processo. São Paulo, ano 8, número 29, pp. 189-216, janeiro/março 2009.

PORTANOVA, Rui. Motivações ideológicas da sentença. 5 ed. Porto Alegre: Livraria do Advogado, 2003.

POZZOLO, Paulo Ricardo. Ação inibitória no processo do trabalho. São Paulo: LTr, 2001.

PRADO, Lídia Reis de Almeida. O juiz e a emoção. 5 ed. Campinas: Editora Millennium, 2010.

PRADO JÚNIOR, Caio. História econômica do Brasil. Atualização de 1970. São Paulo: Brasiliense, 2008.

RENAULT, Luiz Otávio Linhares. MUNIZ, Mirella Karen de Carvalho Bifano. "Meio ambiente e vida: direitos fundamentais convergentes com o direito do trabalho e com o processo do trabalho". In: SENA, Adriana Goulart de (coord). Dignidade humana e inclusão social: caminhos para a efetividade do direito do trabalho no Brasil. São Paulo: LTr, 2010, pp. 56-104.

ROMITA, Arion Sayão. Direitos Fundamentais nas Relações de Trabalho. 4 ed. São Paulo: LTr, 2012.

SADY, João José. Direito do meio ambiente de trabalho. São Paulo: LTr, 2000.

SANTOS, Enoque Ribeiro dos. O dano moral na dispensa do empregado. 4 ed. São Paulo: LTr, 2009. 
SANTOS, Moacyr Amaral. Prova judiciária no cível e comercial. 2 ed. vol. 1. São Paulo: Max Limonad, 1952.

SARLET, Ingo Wolfgang. Dignidade da pessoa humana e direitos fundamentais. 7 ed. Porto Alegre: Livraria do Advogado, 2009.

2009.

A eficácia dos direitos fundamentais. 10 ed. Porto Alegre: Livraria do Advogado,

Algumas notas a respeito dos direitos fundamentais sociais e a proibição de retrocesso: desafios e perspectivas. Cadernos da Amatra IV, ano V, n. 13. Porto Alegre: HS Editora, 2010, pp. 13-47.

SCHIAVI, Mauro. Ações de reparação por danos morais decorrentes da relação de trabalho. São Paulo: LTr, 2007.

SELIGMANN-SILVA, Edith et al. O mundo contemporâneo do trabalho e a saúde mental do trabalhador. Revista Brasileira de Saúde Ocupacional. São Paulo, volume 35, n. 122, pp. 229-248, julho/dezembro 2010.

SILVA, Homero Batista Mateus da. Curso de direito do trabalho aplicado. v. 9. Rio de Janeiro: Elsevier, 2010.

SILVA, José Antônio Ribeiro de Oliveira. A saúde do trabalhador como um direito humano: conteúdo essencial da dignidade humana. São Paulo: LTr, 2008.

SILVA, Otávio Pinto e. Subordinação, autonomia e parassubordinação nas relações de trabalho. São Paulo: LTr, 2004.

SILVA, Virgílio Afonso da. Direitos fundamentais: conteúdo essencial, restrições $e$ eficácia. 2 ed. São Paulo: Malheiros, 2010.

SIMM, Zeno. Acosso psíquico no ambiente de trabalho. São Paulo: LTr, 2008.

SIMÓN, Sandra Lia. A proteção constitucional da intimidade e da vida privada do empregado. São Paulo: LTr, 2000. 
SOUTO MAIOR, Jorge Luiz. Direito processual do trabalho: efetividade, acesso à justiça e procedimento oral. São Paulo: LTr, 1998.

O direito do trabalho como instrumento de justiça social. São Paulo: LTr, 2000.

"As tutelas inibitórias na proteção dos direitos humanos: uma análise na ótica do direito do trabalho". In: CORRÊA, Lelio Bentes. VIDOTTI, Tárcio José (coord.). Trabalho infantil e direitos humanos: homenagem a Oris de Oliveira. São Paulo: LTr, 2005, pp. 210-221.

. Curso de direito do trabalho: teoria geral do direito do trabalho, volume I: parte I. São Paulo: LTr, 2011.

STEINMETZ, Wilson. A Vinculação dos Particulares a Direitos Fundamentais. São Paulo: Malheiros, 2004.

SÜSSEKIND, Arnaldo et al. Instituições de direito do trabalho. 22 ed. São Paulo: LTr, 2005.

TEIXEIRA, Sueli. A depressão no meio ambiente do trabalho e sua caracterização como doença do trabalho. Revista do Tribunal Regional do Trabalho da $3^{\text {a }}$ Região, v. 46, n. 76. Belo Horizonte: julho/dezembro 2007, pp. 27-44.

TEIXEIRA FILHO, Manoel Antônio. A prova no processo do trabalho. 9 ed. São Paulo: LTr, 2010.

THOME, Candy Florencio. O assédio moral nas relações de emprego. 2 ed. São Paulo: LTr, 2009.

TURTE, Samantha Lemos. Violência psicológica e assédio moral no trabalho: percepção e estratégias de enfrentamento de adolescentes trabalhadores. Dissertação de Mestrado. São Paulo: Faculdade de Saúde Pública da Universidade de São Paulo, 2011.

VIANA, Márcio Túlio. Direito de resistência. São Paulo: LTr, 1996.

VIEIRA, Carlos Eduardo Carrusca. Assédio: do moral ao psicossocial. Curitiba: Juruá, 2008. 
VILHENA, Paulo Emílio Ribeiro de. Relação de emprego: estrutura legal e supostos. 3 ed. São Paulo: LTr, 2005.

VILLEGAS, Aldo Zela. Los ámbitos de aplicación de la tutela inhibitoria y la jurisprudencia peruana. Genesis. Revista de Direito Processual Civil. Curitiba, ano 10, número 36, pp. 356-371, abril/junho 2006.

WEIS, Carlos. Os direitos humanos contemporâneos. 2 ed. São Paulo: Malheiros, 2010. 